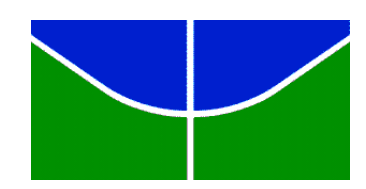

Universidade de Brasília

Instituto de Ciências Humanas

Programa de Pós-Graduação em História

Área de Concentração: História Cultural

Linha de Pesquisa: Identidades, Tradições, Processos

Orientadora: Professora Dra. Eleonora Zicari Costa de Brito

\title{
FESTA RIBEIRINHA: CENAS DE UM BRASIL ANTIGO NAS PRÁTICAS DO CURURU MATO-GROSSENSE
}

\section{ANDERSON ROCHA}




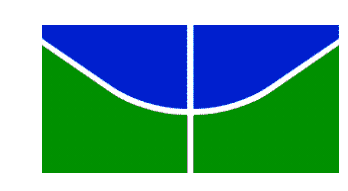

UNIVERSIDADE DE BRASÍLIA

\title{
FESTA RIBEIRINHA: CENAS DE UM BRASIL ANTIGO NAS PRÁTICAS DO CURURU MATO-GROSSENSE
}

\author{
Tese apresentada ao Programa de \\ Pós-Graduação em História da \\ Universidade de Brasília, na Área de \\ Concentração da História Cultural, \\ como requisito para a obtenção do \\ título de Doutor em História.
}

\section{ANDERSON ROCHA}




\section{SUMÁRIO}

RESUMO

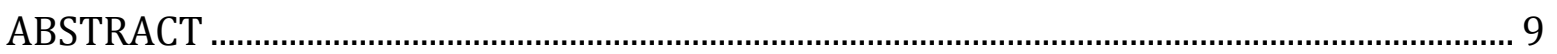

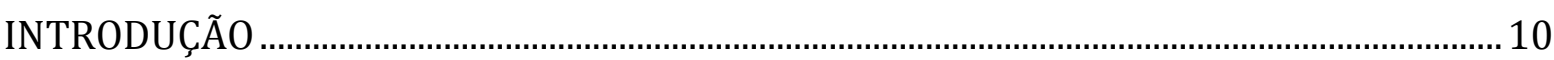

CAPÍTULO I - FORMAS E SIGNIFICADOS .............................................................................. 20

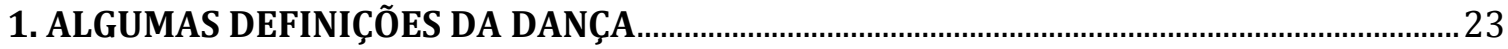

1.1. Cornélio Pires, Americano do Brasil e João Chiarini ....................................................23

1.2. Antônio Cândido, Couto de Magalhães e Mário de Andrade ........................................30

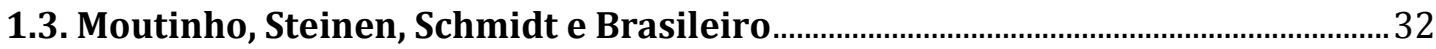

1.4. Tavares de Lima, Maynard Araújo, Ikeda, Damante e Loureiro.................................36

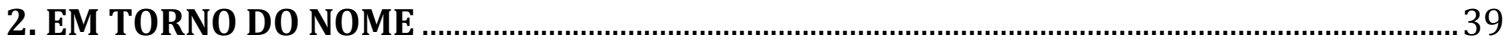

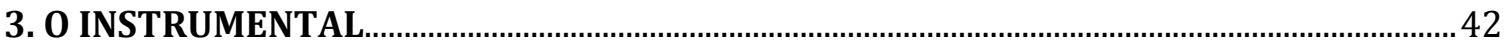

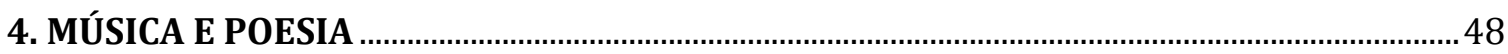

5. COREOGRAFIA

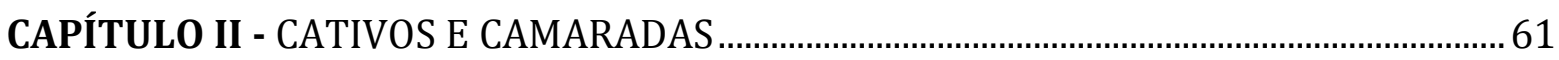

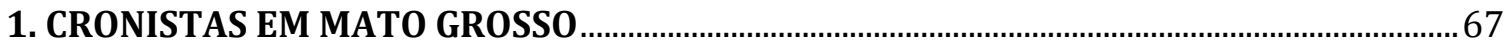

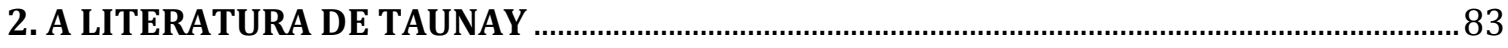

3. REGULAMENTOS

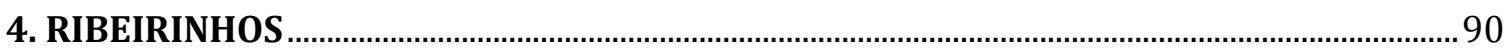

5. 0 HOMEM, A TERRA E SUA CULTURA

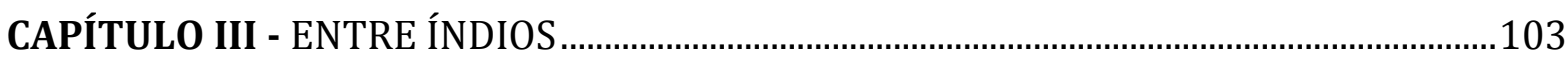

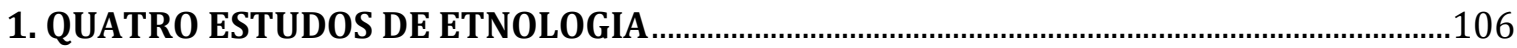

2. A MÚSICA E OS JESUÍTAS NO BRASIL COLONIAL ............................................................120

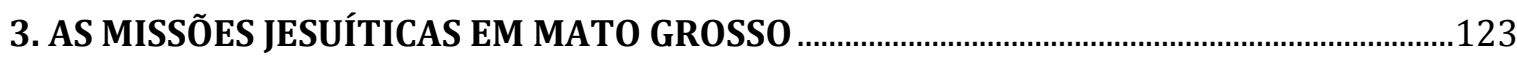

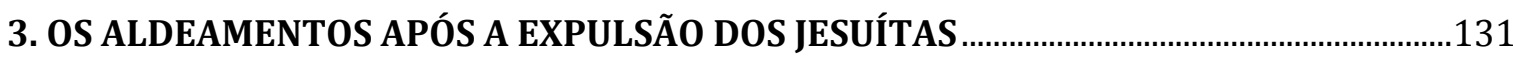

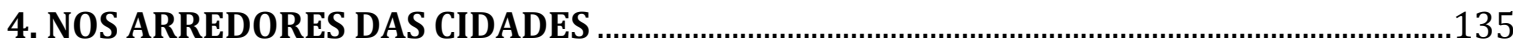




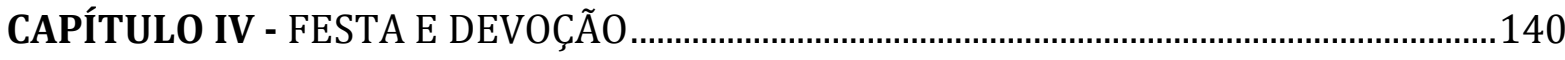

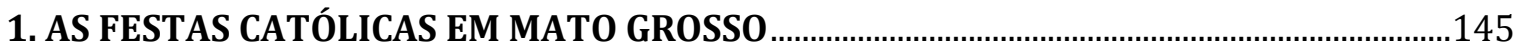

1.1. Festa do Divino Espírito Santo, em Cuiabá

1.2. Festa de São Benedito, em Cuiabá ...................................................................................151

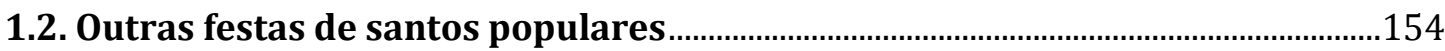

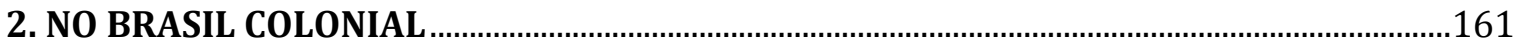

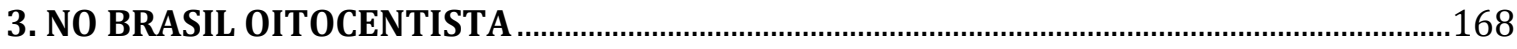

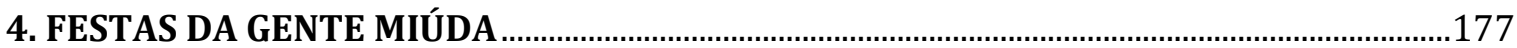

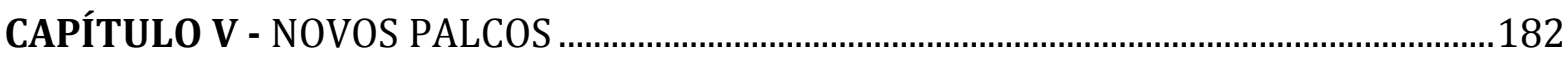

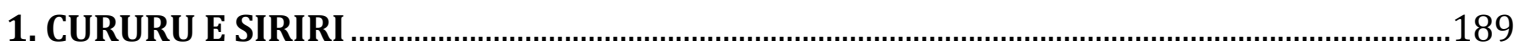

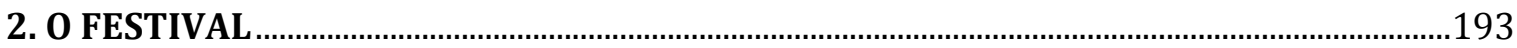

3. A VIOLA-DE-COCHO

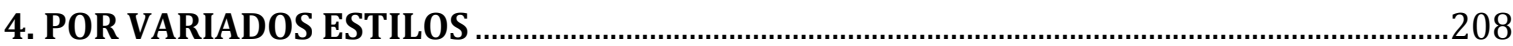

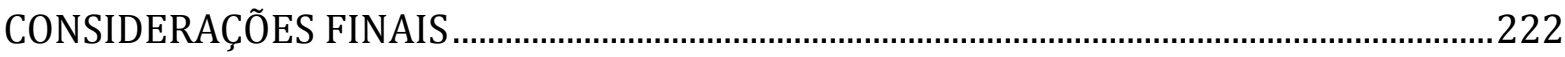

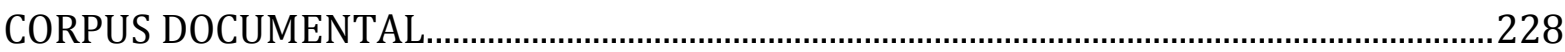

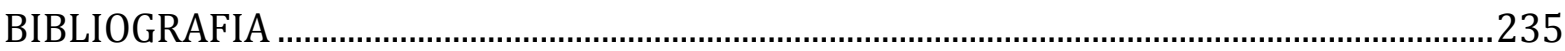

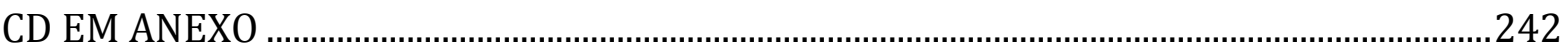


BANCA EXAMINADORA:

Profa. Dra. Eleonora Zicari Costa de Brito - presidente (PPGHIS - UnB)

Profa. Dra. Susane Rodrigues de Oliveira (PPGHIS - UnB)

Profa. Dra. Lylia da Silva Guedes Galetti (ICHS - UFMT)

Profa. Dra. Maria Amélia Garcia de Alencar (PPGHIS - UFG)

Prof. Dr. Mateus de Andrade Pacheco (pesquisador - UnB)

Prof. Dr. José Walter Nunes - suplente (PPGDSCI/CEAM/UnB) 


\section{AGRADECIMENTOS}

Foram várias as pessoas que prestaram valiosa contribuição para a feitura desta tese. Só poderia começar expressando minha enorme gratidão pelo desvelo e pela sabedoria com que Eleonora Zicari Costa de Brito me guiou neste percurso, acreditando sempre no meu aprendizado diante dos desafios da pesquisa.

Meu obrigado às professoras Maria Amélia Garcia de Alencar e Lylia da Silva Guedes Galetti, pelos conselhos, pelas referências e subsídios. Às professoras Tereza Negrão e Márcia Kuyumjian, pelo acesso a leituras e pelas discussões apresentadas em suas disciplinas, a maioria delas imprescindíveis neste trabalho. Destaco também o quanto sou grato pelas inspiradas conversas que tive com Mateus de Andrade Pacheco, primeiramente como colega nos seminários da UnB e depois em nossos cafés com Eleonora. Lembro que algumas das ideias apresentadas no trabalho tiveram início naqueles encontros.

Também quero aqui prestar meu tributo in memorian à nossa querida professora Nancy Allessio Magalhães, membro do PPGHIS-UnB, que nos deixou em julho do ano passado. Suas preciosas contribuições, oferecidas por ocasião do meu exame de qualificação, estão todas aqui, juntas ao mesmo carinho e generosidade dispensados indistintamente aos alunos do Instituto.

Aos meus colegas de trabalho, na Escola de Música e Artes Cênicas da UFG, na pessoa de nossa Diretora Ana Guiomar Rêgo Souza, meu reconhecimento por me permitirem conciliar as obrigações da docência com os compromissos da pesquisa. Obrigado igualmente a Rosângela Roda pelo constante incentivo e pela ajuda na revisão e na montagem do trabalho.

Em Mato Grosso, tive o inestimável apoio dos colegas e professores Abel dos Santos Anjos Filho, Leonardo Yule, Daniel Baier e Jeferson Ribeiro, que me 
abriram os caminhos para a escolha do tema, me inspirando através de seus trabalhos e me apresentando seus amigos e compadres cururueiros. Também guardo na memória o convívio com meus colegas músicos da Orquestra de Mato Grosso e Sinfônica da UFMT, recompensado pela experiência profissional que me permitiu os primeiros contatos com a cultura da região.

Além de todas as pessoas envolvidas, foi igualmente fundamental o apoio institucional e financeiro da Universidade de Brasília - UnB e do Conselho Nacional de Desenvolvimento Científico e Tecnológico - CNPq, que me apoiaram na participação em congressos, nas pesquisas de campo e nos demais esforços exigidos na realização da pesquisa. Meu reconhecimento a estas entidades.

Não poderia deixar de lado a enorme gratidão a meus familiares, primeiramente aos meus pais Edvard e Solange, cujas vivências e convicções formaram em muito a pessoa que sou hoje. Agradeço também a meus irmãos Ivan, Eliane e Sheila, pelo apoio dado em todos estes anos, sem me esquecer de minhas filhas queridas Júlia e Alice, pela paciência e pela torcida demonstradas sempre com a pergunta feita de modo carinhoso: "e aí, pai, já terminou aquele capítulo?"

Por último, minha homenagem a todos os cururueiros que revelaram a mim a beleza de sua poesia. Que eles possam mantê-la viva através de suas gerações. 


\section{RESUMO}

Este estudo trata da arte dos cururueiros em Mato Grosso. Originalmente ligada aos festejos religiosos tradicionais das regiões antigas de São Paulo e Mato Grosso, sua prática assumiu ao longo da história formas e significados distintos em cada um dos locais onde se desenvolveu. Na área paulista do médio Tietê, é hoje baseada no desafio entre cantadores que competem entre si no improviso de versos sobre temas profanos. Em Mato Grosso e Mato Grosso do Sul manifesta-se na forma de dança com canto, mantendo ambas as temáticas, religiosa e profana. Também figura no universo da cultura de massa como gênero de canção caipira, conservando apenas a sua rítmica tradicional. Segundo a maioria dos estudos sobre o tema, o Cururu remonta à época da colonização, como resultado do esforço dos primeiros missionários jesuítas que aqui utilizaram cânticos europeus com o intuito de atrair os nativos para a catequese. Dentre estes estudos, há também aqueles que defendem a hipótese de ser o Cururu uma das danças cerimoniais indígenas que já existiam antes mesmo da chegada ao Brasil dos padres inacianos e que foram por eles adaptadas ao culto católico. Tendo ou não sua origem nos rituais nativos, é certo que o Cururu se formou ao longo dos anos por intermédio de um intenso contato entre as culturas indígena e europeia. Neste contexto, as representações mato-grossenses parecem ser as que mais se aproximam das formas mais arcaicas do Cururu, por preservar seu caráter ritualístico, por manter na dança e no canto um forte acento aborígene e utilizar instrumentos rústicos como a viola-de-cocho. A etnografia da segunda metade do século XIX aos dias atuais constitui-se numa das principais referências para o nosso estudo, sendo através dela analisadas as estruturas poético-musicais, assim como os rastros históricos e o contexto de suas práticas. Igualmente importantes são os documentos legislativos e os processos criminais que regulavam a sua presença na sociedade local do século XIX. Busca-se com esta análise entender como o processo de mestiçagem cultural dos primórdios da prática do Cururu encontra analogias nas formas dinâmicas do seu cultivo contemporâneo.

Palavras chave: Cururu mato-grossense, cultura popular, contatos interétnicos, tradição e invenção. 


\section{ABSTRACT}

This study aims to investigate the art of the 'cururueiros' in Mato Grosso. Originally related to popular religious festivals in the more historic areas of São Paulo and Mato Grosso, this practice has taken different forms and meanings throughout its history. More recently associated with the 'middle' Tiete river region, the Cururu continues to be an expression of the musical 'arguement' between its singers, who compete against each other by improvising musical verses based upon profane subjects. In Mato Grosso and Mato Grosso do Sul the cururu appears in the forms of dance and also by singing, where both religious and profane themes are represented. In mass culture, the cururu is also seen and heard as a folk song genre, where it is popularised and retains only its traditional rhythmic form. According to most studies on the subject, the Cururu dates back to the era of colonization, as a result of the effort of the first Jesuit missionaries that used European songs in order to attract the natives for catechesis. Among these studies, there are those who defend the hypothesis of the Cururu as one of the indigenous ceremonial dances that existed even before the arrival in Brazil of Ignatian priests, which in turn were adapted to Catholic worship. Whether or not its origin is in native rituals, it is certain that the Cururu was formed over the years by an intense connection between indigenous and European cultures. In this context, the representations from Mato Grosso seem to be the ones that come closest to the most archaic forms of Cururu, by preserving its ritualistic character, maintaining strong aboriginal elements of dance and chant and by using rustic instruments such as the viola-de-cocho. Ethnography evolved during the second half of the nineteenth century to the present day is one of the main sources for this study, developed by analyzing the poetic-musical structures, as well as the historical evidence and the context of their practices. Equally important are the legislative documents and criminal records that were kept within local society during the nineteenth century. The objective of this analysis is to understand how the original cultural mixture of Cururu musical practices, correlate with its current transformation process.

Keywords: Cururu in Mato Grosso, popular culture, inter-ethnic contacts, tradition and invention. 


\section{INTRODUÇÃO}

Na primeira vez que estive em visita ao estado de Mato Grosso, em abril de 2006, não imaginava que aproximadamente um mês depois eu fosse residir na sua capital por pouco mais de seis anos. Tratava-se de um convite da recém-criada Orquestra de Câmara de Mato Grosso para atuar como violinista em um dos concertos da sua segunda temporada. Deste trabalho avulso de cinco dias surgiu a oferta para assumir uma das posições no grupo e assim tomei contato com a arte dos cururueiros de Mato Grosso. Na ocasião, uma das propostas da Orquestra era a inserção no contexto da música de concerto de um repertório que fizesse referência a expressões musicais regionais, em especial aos gêneros, Cururu, Siriri e Rasqueado Cuiabano. Para obter o apoio financeiro e político pleiteado junto ao governo, a principal estratégia adotada pelo grupo era a inclusão de um naipe de quatro violas-de-cocho na execução de transcrições e arranjos musicais, além do instrumental de percussão também considerado típico daquelas expressões. Havia, no entanto, a crítica de artistas e estudiosos locais que apontavam a pouca proximidade do grupo com aqueles que deveriam ser os personagens centrais daquelas representações: os músicos tradicionais e os ribeirinhos. Segundo estas mesmas vozes, a proposta regionalista ali apresentada não se constituía numa expressão local, uma vez que boa parte do repertório era de autoria de músicos que nunca haviam pisado em solo mato-grossense. Apesar das críticas, o projeto seguia com o mesmo sucesso de público experimentado no seu início, fazendo uso de uma temática própria dos segmentos subalternos e atribuindo a ela novos sentidos, através de arranjos orquestrais, do emprego de músicos de formação erudita e de apresentações em salas de concerto.

Independente do mérito de tais juízos, eles acabaram provocando em mim o desejo de conhecer melhor esta tradição musical que inspirara a experiência da orquestra local e que antes dela eu sequer havia ouvido falar. Na companhia dos músicos amigos Leonardo Yule e Daniel Baier, conheci alguns cururueiros do 
município de Chapada dos Guimarães, visitando suas casas e participando de algumas celebrações. A estes primeiros contatos, seguiram-se outros, tendo a minha curiosidade voltada desde o início para a força expressiva e o caráter rústico daquele canto.

Em 2010, ainda vivendo em Cuiabá, mas já lecionando nos cursos de música da Universidade Federal de Mato Grosso, avaliei que era o momento adequado para retomar meus planos de doutoramento em uma área envolvendo música e história. As expressões em música da cultura popular de Mato Grosso haveriam de se tornar, a partir de então, o tema a ser estudado. E porque tive a felicidade de residir anteriormente em Brasília e me interessar pela pesquisa desenvolvida pelo Departamento de História da UnB no campo da História Cultural, foi uma decisão natural a de pleitear minha admissão como aluno junto àquele programa. Somouse, por fim, à cadeia de eventos que propiciou o desenrolar da pesquisa nesta linha a inestimável contribuição da professora Eleonora Zicari da Costa Brito, responsável em sua orientação precisa por apresentar-me a maior parte dos autores que fundamentam esta tese.

Os primeiros estudos consistentes sobre o Cururu iniciam em fins da década de 1940. Destacam-se neste período os seguintes trabalhos: Cururu de João Chiarini, publicado em 1947, na Revista do Arquivo Municipal de São Paulo, e Cururu Rural de Alceu Maynard Araújo, apresentado em 1949, na Semana Nacional do Folclore de São Paulo. No primeiro, Chiarini defende a origem exclusivamente lusitana do Cururu por ele observado em cidades da região paulista do Médio Tietê, destacando seu caráter poético centrado no desafio através dos versos improvisados. No segundo, apontando a origem "luso-brasílica" desta expressão, Maynard Araújo faz uma distinção entre o Cururu praticado nas áreas urbanas do estado de São Paulo (sem presença da dança e com temática profana) e o Cururu predominantemente religioso das áreas rurais. Os argumentos de ambos estão fundamentados na observação em campo, com descrições de festas e apresentações, depoimentos de cantadores e transcrições em partitura dos cantos recolhidos. 
Outro importante trabalho é o artigo Possíveis raízes indígenas de uma dança popular, de Antônio Cândido, publicado em 1956, no quarto volume da Revista de Antropologia da USP. Nele, o autor retoma a afirmação feita por Couto de Magalhães e defendida por Mário de Andrade de que o Cururu seria uma dança religiosa tupi, incorporada pelos missionários catequistas às celebrações católicas, fundamentando esta hipótese nos estudos dos etnólogos e antropólogos Curt Nimuenjadú, Alfred Métraux e Herbert Baldus, além da crônica estrangeira sobre o Brasil, do século XVI ao XIX. O artigo, segundo o próprio Cândido, foi o ponto de partida para o livro Os parceiros do Rio Bonito, um estudo sobre as mudanças e permanências na sociedade caipira paulista face ao processo de urbanização, lançado no ano de 1964. Ainda sobre o Cururu paulista, merece destaque a dissertação de mestrado de Eduardo Alberto Escalante, intitulada $A$ música no Cururu do Médio Tietê paulista e defendida na Escola de Comunicações e Artes da Universidade de São Paulo, em 1986. 0 mérito desse trabalho está na apresentação de um extenso material musicográfico, colhido em suas pesquisas de campo, na discografia e nos trabalhos publicados anteriormente, perfazendo um total de 176 documentos musicais. Escalante faz, através desta documentação, uma análise pormenorizada de alguns dos aspectos melódicos, rítmicos e harmônicos, que apontam para as suas possíveis origens, ainda que não trate das letras das toadas com a mesma profundidade.

Dos estudos sobre o Cururu em Mato Grosso e Mato Grosso do Sul, ressalto inicialmente a dissertação de mestrado em História da Cultura, de Eunice Ajala Rocha, defendida na Pontifícia Universidade Católica do Rio Grande do Sul, em 1981, com o título Uma expressão do folclore mato-grossense: Cururu em Corumbá. A autora faz um minucioso levantamento etnográfico das festas tradicionais de santos dos municípios de Corumbá e Ladário, ressaltando o prestígio e a autoridade dos cururueiros na vida religiosa daquelas comunidades. Outra importante contribuição é o projeto conjunto da antropóloga Elisabeth Travassos e do músico e pesquisador Roberto Corrêa, cujas pesquisas realizadas na Baixada Cuiabana nos anos 80 resultaram na organização de exposições e na publicação de artigos e fonogramas, culminando com a colaboração de ambos no Dossiê Iphan 8: modo de fazer viola-de-cocho. Neste livro de 2009, estão reunidos depoimentos de praticantes do Cururu e do Siriri em comunidades tradicionais, registros 
audiovisuais e musicográficos, além de um minucioso levantamento histórico sobre a viola-de-cocho e os gêneros musicais dos quais o instrumento é parte fundamental. Um dos méritos deste trabalho é o de ter reunido uma significativa parte do conhecimento produzido acerca das manifestações paulista e matogrossense, demonstrando através da História as ligações existentes entre elas.

As fontes empregadas em minha pesquisa estão organizadas em três grupos ou categorias distintas. Na primeira, situa-se a crônica de viajantes e etnólogos estrangeiros que visitaram a região no século XIX e início do XX. Um dos autores consultados é o português Joaquim Ferreira Moutinho, com sua Notícia sobre a província de Mato Grosso, publicada em 1869, responsável pela menção mais antiga ao termo Cururu neste tipo de publicação. Outro relato pioneiro é o do francês Francis de Castelnau, com o livro Expedição às regiões centrais da América do Sul, que, mesmo sem nomeá-la, observou no ano de 1845 , ao que tudo indica, a mesma prática musical na região. Também fazem parte desta relação o também francês Hercules Florence, com sua Viagem fluvial do Tietê ao Amazonas de 1825 a 1829, o argentino Julio Koslowsky, com o artigo Tres semanas entre los índios Guatós, de 1895, assim como os etnólogos alemães Karl von de Steinen, com os livros $O$ Brasil Central (1886) e Entre os aborígenes do Brasil Central (1894), e Max Schmidt, com Estudos de etnologia brasileira (1905).

Em um segundo grupo, relaciono os escritos oficiais destinados à regulação das práticas dos folguedos populares no século XIX. Por exemplo, as Posturas da Câmara de Cuiabá, editadas em 1831, que são o mais antigo documento oficial aqui mencionado, tratando, dentre outras questões, da proibição das funções de Cururu que à época ocorriam frequentemente na capital da Província. Também reúno processos e relatórios de ocorrências criminais, como os do chefe de polícia Jesuíno Souza Martins, datados de 1860, acerca dos delitos cometidos nestas mesmas rodas pelos moradores dos arredores de Cuiabá. Os mesmos fazem parte do acervo do Arquivo Público de Mato Grosso - APMT e foram também utilizados em trabalhos anteriores como os dos pesquisadores Luiza Rios Ricci Volpato (1993), Verone Cristina Silva (2011) e Cleber Alves Pereira Júnior (2011), citados nesta tese. Na transcrição dos documentos e das crônicas antigas, optei por 
modernizar a grafia, com o intuito de facilitar a compreensão. Os arcaísmos e a pontuação foram preservados, dentro do possível.

O terceiro grupo compreende as informações e o material coletado pelos folcloristas e cientistas sociais brasileiros que observaram as práticas do Cururu em mais de uma região brasileira. Elas vão desde as descrições de Couto de Magalhães, em sua obra de 1897, Anchieta, as raças e as línguas indígenas, acerca do cultivo da dança entre os Guaianazes da região paulista de Carapicuíba e seus descendentes, passando pelos escritos da década de 1920 de Cornélio Pires, até chegarmos às contribuições de Roberto Loureiro, com sua obra Cultura matogrossense, de 2006. Merecem destaque neste grupo dois exemplos pioneiros. Um deles é o registro fotográfico de uma viola-de-cocho, feito pelo etnólogo alemão Max Schmidt em 1901, por ocasião de sua visita às tribos Guató do Alto Paraguai, no atual Mato Grosso do Sul, publicado no já citado livro Estudos de etnologia brasileira. 0 outro exemplo é a transcrição em partitura musical de cantos dos sertões de Mato Grosso, feitos para o livro Rondônia de Edgard Roquette-Pinto, em 1912, tratando-se do primeiro registro musicográfico do Cururu em Mato Grosso que se tem notícia.

Por último, mas não menos importante, somam-se a esse corpus documental as entrevistas e as descrições que dão testemunho das festas e cantorias, além da coleta das letras e músicas realizadas em minhas incursões pelos espaços de práticas dos cururueiros, realizadas nos anos de 2012 e 2014. Ainda que experimentadas em breves períodos e na condição de observador visitante, esta minha própria vivência em campo, foi de fundamental importância para algumas das conclusões extraídas das realidades abordadas.

Tendo o projeto se desenvolvido no âmbito da História Cultural, vários aspectos explorados na pesquisa tiveram base nos conceitos formulados por alguns de seus teóricos mais importantes. Roger Chartier, por exemplo, ao conceber, em sua obra A história cultural, a diversidade das práticas culturais como atributos não fixos de grupos sociais específicos, forneceu-me subsídios para apontar o modo como os cururueiros não letrados incorporaram em suas cantorias elementos da cultura escrita. Também demonstrou como as disputas simbólicas ou 
de representações têm tanto peso quanto as disputas econômicas, quando um grupo exerce ou tenta exercer o seu domínio. 0 mesmo em relação às noções de apropriação e ressignificação, entendidas por Michel de Certeau em $A$ invenção do cotidiano como o modo como as pessoas e segmentos sociais individualizaram a cultura, alterando seus usos e significados. A exemplo disso, vi cururueiros de Mato Grosso adaptando rapidamente suas rotinas às mostras de folclore, ao comércio em torno do turismo, às viagens e aos palcos, "civilizando" suas práticas e dando novos sentidos a elas. Com a contribuição de Peter Burke e Natalie Zemon Davis sobre os costumes populares na Europa, apresentando em Cultura popular na Idade Moderna e Culturas do povo, respectivamente, a cultura de baixo como um conjunto de formas e elementos de origens distintas, pude traçar paralelos com a tradição popular mato-grossense, igualmente composta de elementos ao mesmo tempo rústicos e eruditos. Dentre eles, as formas próprias de religiosidade desenhadas pela "arraia-miúda" do lugar tiveram destaque graças à leitura de trabalhos como Sacerdotes de viola e Os deuses do povo, do antropólogo Carlos Rodrigues Brandão. Quanto aos estudos sociológicos utilizados na análise do processo civilizatório do país e da região, destaco os trabalhos $O$ povo brasileiro de Darcy Ribeiro, Monções e Caminhos e fronteiras, de Sérgio Buarque de Holanda e Os parceiros do Rio Bonito, de Antônio Cândido, que me auxiliaram na compreensão do papel dos índios, dos sertanejos e dos missionários no ajuste ao meio, no desenvolvimento das relações produtivas e na dinâmica de suas culturas. Outro importante aporte teórico foi o dos antropólogos Nestor Garcia Canclini e Stuart Hall, questionando em Culturas híbridas e A identidade cultural na pós-modernidade o papel atribuído ao popular e suas possíveis aderências aos projetos modernizadores das sociedades contemporâneas, com a consequente fragmentação de suas identidades, em processos que guardam relação com as questões de ressignificação de símbolos e práticas formuladas por Eric Hobsbawn em $A$ invenção das tradições.

0 presente trabalho está estruturado em cinco capítulos. No primeiro, intitulado Formas e Significados, apresento as principais conceituações do Cururu formuladas pelos folcloristas e cientistas sociais que se dedicaram ao tema e relaciono-as não apenas aos aspectos regionais da dança, mas também às 
transformações ocorridas no seu cultivo ao longo do tempo. Ao reconhecer o caráter polissêmico deste gênero, discuto suas características de estilo, forma, instrumentação e funcionalidade, primeiramente como dança com canto nos rituais católicos e nos divertimentos profanos, para, em seguida, descrevê-lo como cantoria sem dança, com temática predominantemente profana e versos improvisados. Além disso, trato da sua presença, como gênero de canção do universo da cultura caipira, no contexto da cultura de massa. Em uma abordagem também etimológica, especulo sobre os caminhos históricos do Cururu, tomando como hipóteses para a origem do nome da dança a influência dos troncos linguísticos Tupi e Macro-Jê, além da possível ambientação de palavras latinas por índios aldeados e seus descendentes. Destaco, por fim, algumas relações do Cururu com as danças coevas de Santa Cruz e São Gonçalo, buscando elucidar as suas possíveis heranças e apropriações.

No segundo capítulo, analiso a prática do Cururu entre Cativos e Camaradas, na sociedade mato-grossense do século XIX. As principais fontes são as crônicas dos viajantes estrangeiros, os códigos de posturas editados pelas autoridades locais e os registros de ocorrências criminais envolvendo indivíduos pertencentes às classes subalternas. Inicio com um retrato da vida musical da província neste período, dando conta não apenas do cultivo da dança nos arredores de Cuiabá e na área rural do sul de Mato Grosso, mas também de algumas expressões de cultura dos demais segmentos da sociedade. Trato, além disso, de aspectos do povoamento da região, cujos primórdios estão intimamente ligados à penetração das bandeiras paulistas, inicialmente para a captura de índios para o trabalho escravo e posteriormente para a exploração das minas de ouro e diamante descobertas no final do século XVII. A promessa de riqueza das minas de Cuiabá atraiu colonos de diversas localidades, estabelecendo em suas terras uma rede de atividades em torno da mineração, ligando a ela tanto o transporte fluvial entre São Paulo e Cuiabá quanto o comércio nos povoados e a produção das fazendas, o que possibilitou a reprodução dos modos de vida do mundo rural no centro-sul brasileiro gestados desde os primeiros tempos da Colônia. Busco, neste processo, entender a tênue distância entre o lugar social do escravo e do trabalhador livre e pobre da região, determinada pela distância física dos centros da economia nacional e a carência de recursos monetários necessários na compra desta força de 
trabalho. Por fim, reflito sobre outra designação genérica para o habitante pobre da região, a do ribeirinho. Este tipo, tradicionalmente representado pelo habitante das proximidades dos rios, cujo meio de subsistência circunscreve-se não apenas à coleta de peixes, será também identificado por outras atividades desempenhadas no campo e no entorno das cidades, com sua cultura, porém, fortemente vinculada ao mundo rural e à herança indígena.

No terceiro capítulo, Entre Índios, reflito sobre o processo de colonização e as representações culturais acolhidas na região, através da etnologia de povos nativos. Inicio com os diários de viagem dos naturalistas Castelnau, Koslowsky, Schmidt e Steinen, que são as mais completas fontes de informações acerca da dança do Cururu e dos hábitos cultivados em torno dela, pelos índios Guató, Guaná e Bacairi de Mato Grosso, entre os anos 1845 e 1901. Em seguida, abordo o contato dos índios do litoral com os missionários jesuítas que primeiro vieram ao Brasil, reconhecendo no uso da música trazida da Europa para a catequese o início de um processo de fusão de culturas que resultará em expressões até hoje presentes em algumas partes do país. Também trato das missões religiosas em Mato Grosso iniciadas com a vinda dos jesuítas da América espanhola para a região, no século XVII, e com a chegada dos inacianos de origem portuguesa, por ocasião da criação da Capitania de Mato Grosso, em 1750. Por fim, ocupo-me dos relatos e da documentação sobre a política de aldeamento indígena no século XIX e do deslocamento destas populações para as principais cidades da província. Esta ampla cronologia se justifica em razão do contato intercultural entre índios, colonos e missionários ter ocorrido em Mato Grosso até meados do século XIX de uma forma análoga aos processos de aculturação vividos pelos índios, colonos e missionários do Brasil colonial, fazendo deste um dos importantes cenários das práticas mais arcaicas do Cururu.

O tema central do quarto capítulo, Festa e Devoção, é o modo como a religião popular se configura em Mato Grosso através das suas festas de santos. Busco desenvolvê-lo através da análise de algumas das atuais representações festivas locais, vistas como memória de um passado que teve no Catolicismo uma das principais forças coordenadoras na implantação em terras brasileiras do projeto civilizatório lusitano. Descrevo três tipos de manifestações: as festas de santos das 
irmandades, promovidas pelas comunidades dos aglomerados urbanos; as festas de santos de famílias, que normalmente abriam as portas das residências familiares a todos; e as festas de santos rurais, que mobilizavam os moradores das suas redondezas. Inicio apresentando as festas do Divino, São Benedito, São João, São Gonçalo e Sant'Ana, nos municípios mato-grossenses de Cuiabá, Poconé e Rosário Oeste, incluindo Corumbá, em Mato Grosso do Sul, baseadas nos relatos e na iconografia da época, assim como nas observações em campo por mim realizadas nos anos de 2012 e 2014. Combinando o sacro e o profano em suas rezas, danças, simpatias, comidas e procissões, a experiência desses homens e mulheres nos permite relacionar sua história não só aos ritos católicos dos aldeamentos jesuítas e arraiais dos colonos dos primeiros séculos no Brasil, como também às práticas populares da Europa no início da era moderna, onde às camadas subalternas eram permitidos espaços de aproximação, de sincretismos e de simulacros de uma maior permeabilidade social.

Com o título Novos Palcos, o quinto e último capítulo trata do papel da política na formação de uma identidade local, levando em conta as escolhas feitas pelos seus agentes no sentido de privilegiar, a partir de um determinado momento, a temática rural e as representações culturais oriundas das suas populações ribeirinhas. Para tanto, discuto o modo como são formulados estes discursos legitimadores e relaciono-os à criação de novos espaços para o popular (os festivais, os eventos de turismo, os programas televisivos, os cursos e as mostras em museus e casas de cultura). Também busco estabelecer analogias com algumas das práticas contemporâneas do cururu em São Paulo, hoje presentes nos torneios de cantadores do Médio Tietê e no mercado fonográfico, como um subgênero da música caipira. Outro aspecto abordado são as propostas de diálogo entre estilos, com experiências na música de concerto e nas diversas vertentes musicais da cultura de massa, como o pop-rock, a música de raiz e os gêneros "brega", entre outros. Por último, reflito sobre a representação da viola-de-cocho como principal símbolo da cultura em Mato Grosso, analisando não só o seu status de patrimônio cultural do Estado, como também o emprego de sua imagem para além do sentido musical, nas artes visuais e na publicidade, com a consequente saturação de uma mensagem disseminada na forma de clichês. 


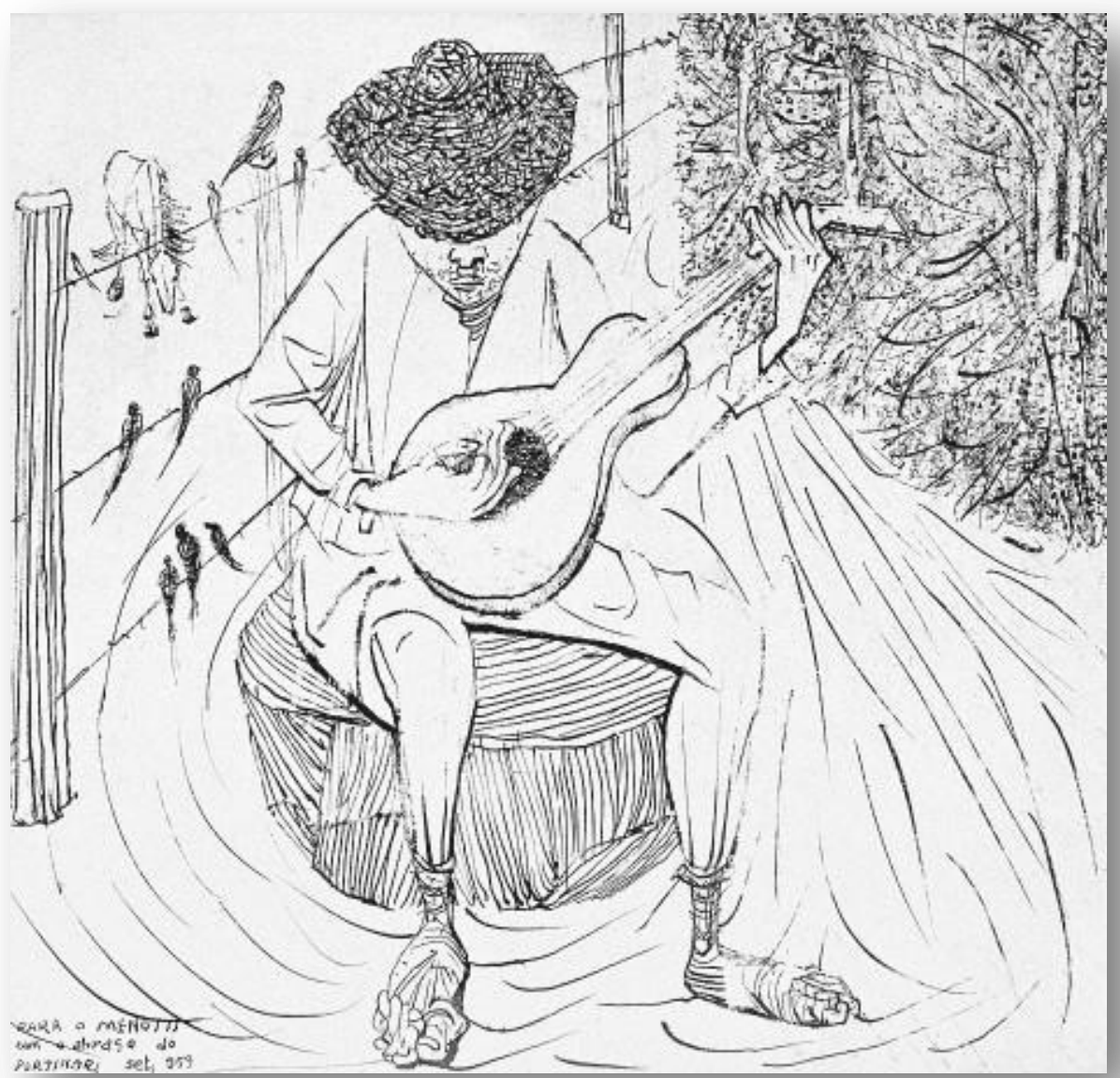

Juca Mulato, gravura de Cândido Portinari (1959)

Fonte: Menotti Del Picchia, 1978 


\section{CAPÍTULO I}

\section{FORMAS E SIGNIFICADOS}

Você verá que desta festa falarão...

E o sapateado à noite? Os descantes? Talvez se possa arranjar um cururu valente...

Visconde de Taunay, Inocência, 1872

Às vezes descrito como uma dança cerimonial do catolicismo popular, às vezes como um desafio profano entre cantadores, o Cururu permanece vivo como expressão da cultura tradicional em regiões como a Baixada Cuiabana no estado de Mato Grosso, em partes velhas de Mato Grosso do Sul como o município de Corumbá, e nas áreas paulistas do Médio Tietê e Carapicuíba. De uma forma não homogênea, está difundido em alguns destes lugares como dança recreativa e em outros como dança religiosa, traduzido em versos que cantam passagens do Evangelho, em lamentos do cotidiano ou em pilhérias entre os seus contendores. Em outro contexto, o da cultura de massa, é também o nome dado a uma das modalidades da canção caipira ou sertaneja, completando assim o seu leque atual de configurações. Seus representantes, os cururueiros, são chamados a cantar e dançar por horas a fio nas festas de santos, a se exibir durante alguns minutos em shows e mostras de folclore, ou se apresentar (não mais com a dança) em longos torneios onde disputam entre si o título de melhor improvisador de toadas.

E para explicá-lo através de alguns dos seus aspectos formais, exclusivamente relacionados à música, a poesia e a dança, é necessário ter em mente as limitações e dificuldades que a tarefa impõe ao investigador. Importa identificar, por exemplo, as particularidades melódicas e rítmicas que o aproximam e às vezes o confundem com outros gêneros coetâneos (além da atenção prestada às funções harmônicas que caracterizam, na sua simplicidade, toda a música pertencente ao universo da cultura 
popular no centro-sul brasileiro) e reconhecer, ao mesmo tempo, que as suas variantes regionais, acentuadas entre outras razões pela adaptação a formas contemporâneas de lazer festivo e fruição musical, tornam complicado o estabelecimento de alguns padrões usados para defini-lo musicalmente. 0 mesmo problema deve ser visto no estudo da sua poesia, uma vez que nem sempre há um consenso a respeito da sua classificação quanto à temática ou o tipo de improviso usado nos desafios cantados. Outro ponto a ser observado nas letras é o modo como elas diferem entre si em sua forma, seja quanto à métrica dos versos e o número de estrofes, seja quanto ao uso da rima. No tocante à análise dos passos da dança, também cabe apontar disparidades como as que se vê na abordagem musical ou literária, embora os etnógrafos atentem mais para uma pequena quantidade de detalhes, geralmente descrevendo a coreografia como sendo apenas de movimentos simples, com os participantes dispostos em círculos ou em duas fileiras diante do altar do santo homenageado. Ainda assim, há aspectos na dança que são reportados em apenas alguns casos, como o emprego do sapateado e das palmas, que também merecem ser analisados.

Estas são algumas das questões, até aqui apresentadas de modo sucinto e à guisa de introdução, que explicam o fato de ser hoje o Cururu objeto de uma análise majoritariamente centrada em aspectos contextuais, como, por exemplo, a sua função social, os grupos étnicos praticantes, as épocas e os locais observados, além da sua recepção por parte do poder e da sociedade em geral. Sendo assim, o presente capítulo tem o intuito de analisar o Cururu através de suas formas e significados. Para tanto, são inicialmente apresentadas as principais conceituações deste gênero de canto e dança formuladas pelos estudiosos Antônio Cândido, Americano do Brasil, Câmara Cascudo, Cornélio Pires, Couto de Magalhães, Francisco Brasileiro, Hélio Damante, João Chiarini, Mário de Andrade, Maynard Araújo, Roberto Loureiro e Rossini Tavares de Lima. São também citados os principais relatos antigos sobre o tema, elaborados por etnólogos e cronistas estrangeiros como Karl von den Steinen, Max Schmidt e Joaquim Moutinho, que durante suas estadas em território matogrossense se depararam com práticas e costumes merecedores de seus olhares. Através do cotejamento destes autores, é possível não apenas conhecer melhor as 
características e os elementos estruturantes da dança, como também perceber os regionalismos e as transformações ocorridas no seu cultivo ao longo do tempo.

Outra abordagem essencial para este estudo é a etimológica. Por intermédio de autores como Antônio Cândido, Barbosa Rodrigues, João Ribeiro e Sérgio Buarque de Holanda - trazendo como hipóteses para a origem do nome da dança a influência dos troncos linguísticos Tupi e Macro-Jê, além da possível deturpação de palavras latinas por índios aldeados e seus descendentes - as explicações acerca da procedência e o significado do termo constituem-se importantes ferramentas para a compreensão dos caminhos históricos do Cururu. Contribuem, entre outros aspectos, para explicar o modo como esta prática pôde se desenvolver no seio de algumas tribos indígenas, como a dos Guató e os Guaná nos estados de Mato Grosso e Mato Grosso do Sul e a dos Guaianá em São Paulo, observadas na segunda metade do Século XIX e inícios do século XX.

Os instrumentos musicais utilizados no acompanhamento da dança são outro importante componente a ser considerado nesta análise. 0 pequeno conjunto musical que compõe as rodas de Cururu em Mato Grosso, constituído hoje de violas-de-cocho e ganzás, guarda diferenças em relação à formação instrumental empregada no Cururu paulista e tem no primeiro dos instrumentos citados um dos símbolos da cultura pantaneira. Sendo estes detalhes mais que um simples indicativo da sonoridade característica de uma região, o seu enfoque permite esclarecimentos acerca do modo como estas expressões musicais se engendraram na cultura da região e dos segmentos da sociedade que vieram a compor este processo.

Minha opção foi também a de utilizar para este estudo alguns trechos musicais em partitura, assim como transcrições de letras das toadas e esquemas representativos das coreografias. São registros pertencentes em sua maioria à etnografia dos autores aqui citados, tendo sido uma parte deste material por mim coletada nos meses de junho e julho de 2012 e setembro de 2014. Sem que sirvam necessariamente como principal base empírica para esta análise, as descrições das danças e as transcrições dos cantos aqui analisados são exemplos que possibilitam um maior aprofundamento dos conceitos formulados em pesquisas anteriores, além de respaldar os resultados de novas observações. 


\section{ALGUMAS DEFINIÇÕES DA DANÇA}

Nesta seção comento os principais autores que se dedicaram ao relato do Cururu em São Paulo, Goiás e Mato Grosso, a partir de suas conceituações sobre este gênero de canto e dança. Para ilustrá-las, são também selecionados versos de toadas, recolhidos por ocasião das pesquisas de campo realizadas por esses autores, além do próprio material por mim recolhido. Os autores não aparecem aqui agrupados segundo uma ordem estritamente cronológica, mas sim através do critério regional para uns e do tipo de abordagem ou método de análise para outros, sendo hoje estes textos uma parte representativa da história das narrativas do Cururu. Escritos que terminaram por atribuir sentidos a essa arte como memória selecionada conforme cada contexto, considerando, como nos lembra Certeau, que o "memorável é aquilo que se pode sonhar a respeito do lugar". 1

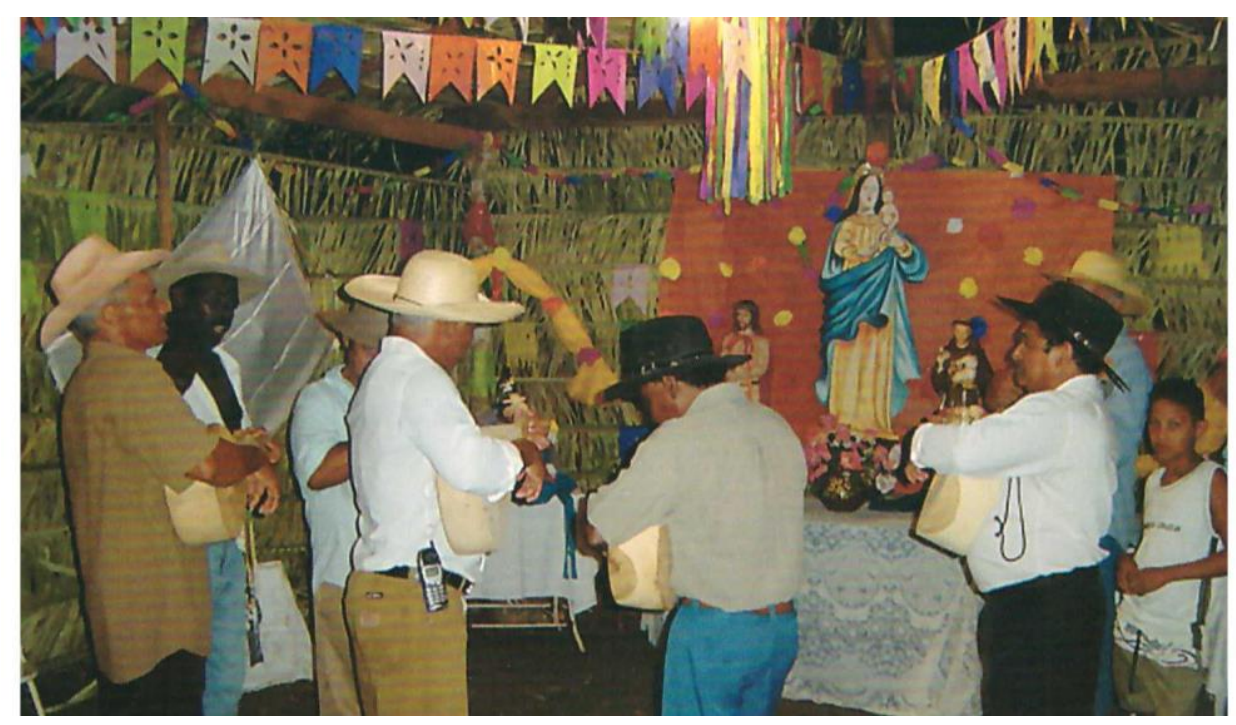

Figura 1: Dança diante do altar Fonte: Loureiro, 1993

\subsection{Cornélio Pires, Americano do Brasil e João Chiarini}

Em seu livro Conversas ao pé-do-fogo, publicado em 1921, o folclorista, jornalista e escritor paulista Cornélio Pires assim define o Cururu:

\footnotetext{
${ }^{1}$ CERTEAU, Michel De. A Invenção do Cotidiano: arte de fazer. Petrópolis: Vozes, 1994, p. 190.
} 
Dança em que tomam parte os poetas sertanejos, formando roda e cantando cada um por sua vez, atirando os seus desafios mútuos. [...] Os "cururueiros" cantam sem amostras de cansaço, desde o anoitecer até o amanhecer. É uma dança mista do africano e do bugre².

Neste verbete, o autor é enfático na caracterização do Cururu paulista das primeiras décadas do século XX como uma dança, ressaltando também a importância da arte do improviso no canto incessante dos seus "poetas sertanejos". Estes dois aspectos fazem do testemunho de Cornélio Pires um dos mais valiosos, pois indicam, a um só tempo, a presença na região do desafio (o principal atributo dos cururueiros paulistas, atualmente) e da dança (um componente já não mais encontrado no Estado). 0 escritor tieteense cita ainda uma das generalizações mais importantes na dança que é a formação dos cururueiros em círculo e menciona a identidade mestiça da cultura caipira, quando diz tratar-se de uma "dança mista do africano e do bugre". Em outro escrito, Cornélio Pires ressalta o caráter também religioso da dança, descrevendo uma cena rural em que "caboclos, pretos e mulatos" cantam "na carreira do Sagrado" 3 , em frente ao altar da sala, na morada de um dos festeiros:

Nóis aqui temo reunido

Na carrêra do Sagrado:

Nóis viemo aqui lová

Bão Jesuis Crucificado,

Sinhor de tanta alegria

Qui nóis home tem guiado4.

\footnotetext{
2 PIRES, Cornélio. Conversas ao pé-do-fogo. Itu, SP: Ottoni, 2002, p. 109. Cornélio Pires (1884-1958) foi pioneiro na promoção da cultura caipira junto à população urbana do estado de São Paulo. Iniciou em 1910 uma bem-sucedida carreira de empresário e ativista cultural, ao organizar um espetáculo no Colégio Mackenzie de São Paulo que reunia catireiros, cururueiros e demais representantes do folclore musical do interior paulista. A partir deste evento, passou a registrar os costumes, o vocabulário, a poesia, os casos e anedotas dos caipiras em mais de vinte livros publicados. Promoveu, no final da década de 1920, o lançamento pela indústria fonográfica dos primeiros discos $78 \mathrm{rpm}$ do gênero, adaptando-o ao formato fonográfico e lançando assim as bases da música sertaneja. Em 1946, fundou a companhia O Teatro Ambulante de Cornélio Pires, que percorreu o interior paulista, apresentando-se em praças públicas com grande sucesso de público. Cf. Enciclopédia da música brasileira. São Paulo: Art Ed., 1977, v.2 p. 614-5.

3 PIRES, Cornélio. Apud LIMA, Rossini Tavares de. O folclore na obra de escritores paulistas. São Paulo: Imprensa Oficial do Estado, 1962, p. 22.

${ }^{4}$ Idem.
} 
Após a louvação aos santos do altar e as homenagens também feitas ao dono da casa, as toadas do Cururu passam a ter outro destino. Tornam-se "desaforados desafios", com os cantadores satirizando uns aos outros, como nos versos abaixo, em que um dos cantadores é criticado por finalizar o canto religioso antes da hora:

Meu amigo cantorino

isto i vai lá pro seu lado,

- gosto de vê cantadô

na carrêra do Sagrado.

Aqui é preciso lová

Bão Jesuis Crucificado

i as image deste artá,

tão bunito, aperparado,

- do jeito que vóis cantô

é jeito de marcriado!

Cantadô de sua iguaia

inda num tenho encontrado

num canta da religião

fala só barbaridades.

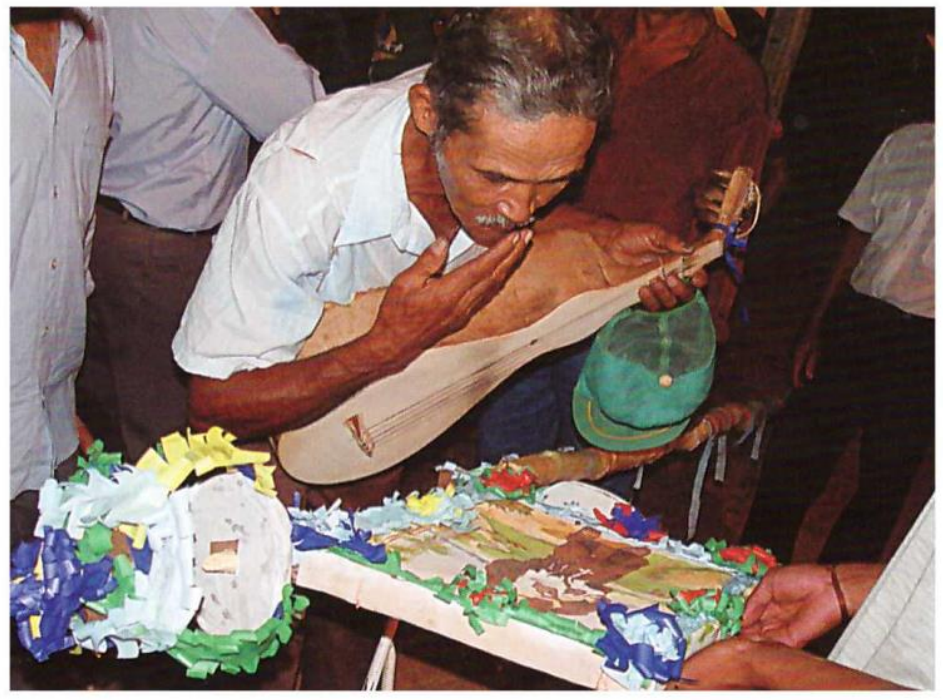

Figura 2: Devoção a Santo Antônio

Fonte: Loureiro, 2006

\footnotetext{
${ }^{5}$ Idem.
} 
A etnografia de Cornélio Pires também se destaca das demais por ter o autor nascido e vivido na região do Médio Tietê, numa época em que pôde presenciar algumas das práticas antigas que hoje persistem em alguns casos apenas no Cururu mato-grossense. São elas a dança dos cururueiros e as "carreiras" em louvor aos santos católicos.

O médico, político, escritor e folclorista goiano Antônio Americano do Brasil é responsável por uma das raras menções à prática do Cururu em sua província. Em seu livro de 1925, Cancioneiro de trovas do Brasil Central, há um capítulo específico sobre as "danças populares antigas e atuais dos sertões goianos" que define o Cururu da seguinte maneira:

O Cururu é uma dança em que dois violeiros mostram unicamente a habilidade de rimar sobre diversos assuntos, dançando os companheiros ao som da viola e sob a animação dos versejadores. A dança se faz em roda, a palmas e sapateados ${ }^{6}$.

Paralelamente a outras danças como o batuque, o saruê, o vilão, a cana-verde, o recortado, a dança dos tapuios, a piranha e a catira, o autor caracteriza a prática do Cururu através de dois aspectos: a temática poética (com versos rimados "sobre diversos assuntos") e a coreografia (com os participantes dançando em roda, sapateando e batendo palmas). Além disso, com a dança praticada, ao que parece, por todos folgazões, excetuando os que se encarregavam do canto e da viola. Sobre o improviso nos versos, Americano do Brasil faz também uma ressalva, dizendo que estes não faziam do Cururu uma daquelas modalidades de canto em que os cantadores mediam, antes de tudo, os seus talentos de improvisação, como nas cantorias do nordeste brasileiro.

É a dança desafio que não deve ser confundida com o característico desafio, que é um dueto poético entre dois rimadores, apanhando cada um, e isto nem sempre, o primeiro ou o último verso da trova do adversário ${ }^{7}$.

\footnotetext{
${ }^{6}$ AMERICANO do BRASIL, Antônio. Cancioneiro de trovas do Brasil Central. Goiânia, GO: Oriente, 2a ed. 1973, p. 264.

${ }^{7}$ Idem.
} 
Para ilustrar o seu relato, o escritor goiano transcreveu algumas quadras de um Cururu ouvido por aquelas bandas:

Eu não sou pau de porteira,

Mourão de jacarandá

Eu não sou pires de doce

Pra vancê vir me prová.

Eu me chamo topa-topa,

Cai aqui, cai acolá,

Gente não gosta de mim

Eu topo em vosso lugá.

Oncê não me conhece

Nem não sabe quem eu sou,

Eu chamo mundé armado

Quando dispara pego.

Oncê diz não me conhece

Eu te dou a conhecê:

Eu me chamo Juca Mole,

Coitadinho de vancê.

Enrola já seu cabelo

Não o traga desatado,

Debaixo da trunfa trago

Um amor que é meu guardado.

Se eu soubesse de avoá

Que avoava e não caía,

Avoava nestes ares

Ia ver que você fazia.

Eu pensei que eu lhe tinha

Pago o meu contentamento,

Te acho tão demudada 
Com a mudança do tempo.

Sim, já é bastante tempo

Para em nós haver mudança,

O nosso amor não é firme

É brinquedo de criança ${ }^{8}$

Até onde se sabe, esta é a mais detalhada referência feita a uma prática do Cururu em terras goianas. Além dela, possuímos a afirmação genérica de Couto de Magalhães, que em 1897 dizia ter ouvido toadas do Cateretê e do Cururu "rezadas" em várias regiões por onde passou, incluindo São Paulo, Bahia, Minas, Cuiabá e Goiás. Antônio Cândido, por sua vez, reproduz em 1956 a informação oral do antropólogo Herbert Baldus, reportando o cultivo no norte de Goiás de "uma dança com este nome, por sertanejos vindos do Norte ou do Nordeste". Com base apenas nestas informações, não é possível assegurar que a ocorrência do Cururu em um momento passado da província de Goiás tenha sido algo além do intercâmbio esporádico dos seus moradores com músicos e festeiros de outras regiões. Tampouco elas permitem conjeturas acerca de um possível processo de perda ou transformação da tradição musical do lugar, tendo o Cururu como uma das expressões. Mesmo assim, a contribuição de Americano do Brasil, quando somada a dos demais folcloristas e etnólogos que à época se dedicaram aos cantos e danças dos caipiras do centro-sul e centro-oeste brasileiros, é determinante para o mapeamento da área de difusão desta cultura.

Nos seus estudos de folclore, o piracicabano João Chiarini situa os combates poéticos travados pelos cururueiros paulistas na mesma categoria do ofício dos repentistas nordestinos, levantando a hipótese de serem ambos originários do trovadorismo ibérico e provençal da Idade Média (em especial, dos cancioneiros galego-portugueses) ${ }^{9}$. Com isso, Chiarini contesta a afirmação de que o Cururu seria uma dança ameríndia adaptada pelos jesuítas ao culto católico. Para ele, trata-se de uma folgança importada de Portugal, que aportou primeiramente na Bahia com as

\footnotetext{
${ }^{8}$ Ibidem, p. 264-5.

${ }^{9}$ CHIARINI, João. Cururu. In: Revista do Arquivo Municipal São Paulo. SP: Dep. de Cultura, 1947, p. 86.
} 
naus dos colonos e lá mesmo iniciou a sua miscigenação. Chegando à zona interiorana do Sul, tornou-se "mais puro, mais indígena" 10. Daí que, para este autor, o Cururu

[...] nada mais é que um desafio entre cantadores, que improvisam sempre obedecendo às carreiras que são postas pelo "pedreste" [sic]. Carreira para eles é rima. Esta interessa no Cururu, quando dentro da toada $^{11}$.

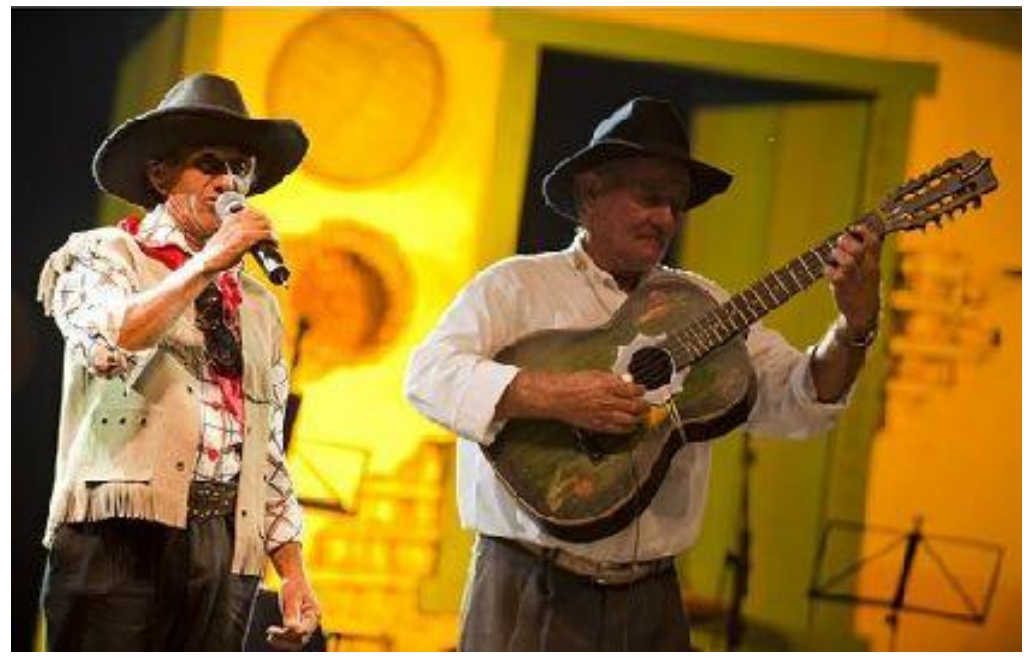

Figura 3: Cururu em Tatuí, SP

Fonte: Franco, 2010

O paralelo traçado por João Chiarini entre o Cururu e os desafios cantados como no repente nordestino não se limita ao reconhecimento da primazia do improviso poético sobre a melodia e a dança. $\mathrm{O}$ autor aponta o mesmo diferencial notado por Americano do Brasil ao descrever o Cururu em sua província.

Uma distinção é: que no desafio do norte se faz uma quadra e o adversário já a responde. Outro verso, outra resposta. No Cururu não é assim. Cada 30 ou 40 minutos se exibe um trovador e a sua ordem na cantoria o é de acordo com o resultado do sorteio que lhe coube. Isto não se dá no desafio nordestino ou mesmo no do sul, ou no do centro $^{12}$.

Chiarini observa ainda que alguns dos gestos notados nas práticas de seu tempo (a roda dos participantes em torno de um tablado ou um terreiro, os volteios e

\footnotetext{
10 Ibidem, p. 87.

11 Ibidem, p. 92.

12 Ibidem, p. 96.
} 
os movimentos de flexão das pernas) não faziam do Cururu uma dança, efetivamente. Estes pertenciam a folgas de outra natureza (por exemplo, aos batuques, sambas rurais ou cateretês dançados nas festas populares do interior paulista), sendo este argumento ilustrado com o depoimento de vários cantadores antigos da região que, perguntados, disseram desconhecer um Cururu dançado ${ }^{13}$. Também justificava dizendo que, ao girar em roda, o participante desafiado (chamado pelos cururueiros de "contrário") não poderia "atentar direito aos versos que lhe [eram] arremessados", preferindo ouvir quieto em seu canto o ataque e já ir cuidadosamente "parafusando a resposta" ${ }^{14}$. Porém, o que Chiarini talvez tenha desconsiderado em sua análise é que o Cururu, antes de se firmar como desafio cantado de temática predominantemente profana, era cantado e dançado sobretudo nas festas joaninas e nos pousos do Divino das fazendas e arraiais da região, rogando proteção, pagando uma promessa e celebrando a fé, a exemplo de outras danças de devoção como a de Santa Cruz e São Gonçalo ${ }^{15}$.

\subsection{Antônio Cândido, Couto de Magalhães e Mário de Andrade}

O sociólogo e crítico literário Antônio Cândido, em seu artigo de 1956, Possíveis raízes indígenas de uma dança popular, adota as explicações de Couto de Magalhães (também defendidas por Mário de Andrade) a respeito do Cururu dos caboclos da área de povoamento paulista. Segundo tais explicações, o Cururu seria originalmente uma dança cerimonial indígena que fora assimilada pelo culto católico, através do esforço catequético dos missionários jesuítas, no início da colonização portuguesa. Cândido procura fundamentar esta teoria através da contribuição de antropólogos e etnólogos indigenistas que estudaram especialmente os rituais de alguns dos povos da família linguística Tupi ${ }^{16}$. Assim Cândido define o Cururu:

[...] É dança praticada pelos caboclos de São Paulo, Goiás e Mato Grosso. Em nosso Estado, não se encontra por toda a parte, mas em certas zonas velhas - notadamente a periferia da capital e a Baixa

\footnotetext{
${ }^{13}$ Ibidem, p. 97-8.

${ }^{14}$ Ibidem, p. 96.

15 ARAÚJO, Alceu Maynard. Cultura popular brasileira. São Paulo: Melhoramentos, 1973, p. 63-5. Ver também BRANDÃO, Carlos Rodrigues. Sacerdotes da viola: rituais religiosos do catolicismo popular em São Paulo e Minas Gerais. Petrópolis: Vozes, 1981, passim.

${ }^{16}$ CÂNDIDO, Antônio. Possíveis raízes indígenas de uma dança popular. In: SHADEN, Egon. Leituras de etnologia brasileira. São Paulo: Cia Ed. Nacional, 1976, p. 387-9.
} 
Sorocabana. Fora daí, ocorrerá por difusão recente, e tudo leva a crer que se tenha formado na primeira das áreas mencionadas. As suas formas são várias, mas essencialmente consta de uma dança rodeada em que tomam parte via de regra apenas os homens; de uma saudação aos presentes; uma louvação aos santos e finalmente desafios em que os contendores - sempre dançando - propõem uns aos outros problemas, de fundo religioso ou profano, visando derrotar o adversário e exaltar a própria pessoa ${ }^{17}$.

Além de afirmar a existência da dança como um componente essencial do Cururu, Cândido não hesita em afirmar que o mesmo se irradiou a partir de regiões velhas de São Paulo, sendo a sua manifestação em terras mato-grossenses o fruto de um processo de difusão ocorrido posteriormente. Outro aspecto abordado são as partes que o compõe, basicamente as mesmas descritas por João Chiarini: a saudação aos presentes, a louvação aos santos e os desafios dos cantadores. 0 mais importante na sua conceituação é, todavia, a questão relativa às origens da dança. Couto de Magalhães, um dos autores que defendeu anteriormente esta hipótese, diz o seguinte, em uma conferência de 1897:

Os jesuítas não coligiram a literatura dos aborígenes, mas serviramse de sua música e de suas danças religiosas para atraí-los ao cristianismo. Entre essas danças haviam duas, o cateretê e o cururu, que eram religiosas para os tupis e guaranis, e que todos os filhos do interior do Brasil conhecem. [...] As toadas profundamente melancólicas destas músicas e a dança foram adotadas pelos jesuítas, com o profundo conhecimento que tinham do coração humano, para as festas do Divino Espírito Santo, S. Gonçalo, Santa Cruz, S. João e Senhora da Conceição ${ }^{18}$.

Em 1929, Mário de Andrade também fala conjuntamente do cateretê e do Cururu, presenças frequentes nas festas católicas tradicionais:

Entre as nossas formas coreográficas, uma das mais espalhadas é o Cateretê ou a Catira, dança de nome tupi. Anchieta para catequizar os selvagens já se aproveitava dela, parece, deformando-lhe os textos no sentido da Religião Católica. Caso mais indiscutível ainda dessa fusão

\footnotetext{
${ }^{17}$ Ibidem, p. 385.

18 COUTO de MAGALHÃES, General. Anchieta, as raças e as línguas indígenas. $7^{\mathrm{a}}$ Conferência para o tricentenário de Anchieta. São Paulo: Typografia C. Gerke e Cia, 1897, p. 27.
} 
ameríndio-jesuítica é o do Cururu. Em certas festas populares, religioso-coreográficas, tais como a dança de São Gonçalo e a dança de Santa Cruz, pelo menos nos arredores de São Paulo, após cada número do cerimonial, dança-se um Cururu ${ }^{19}$.

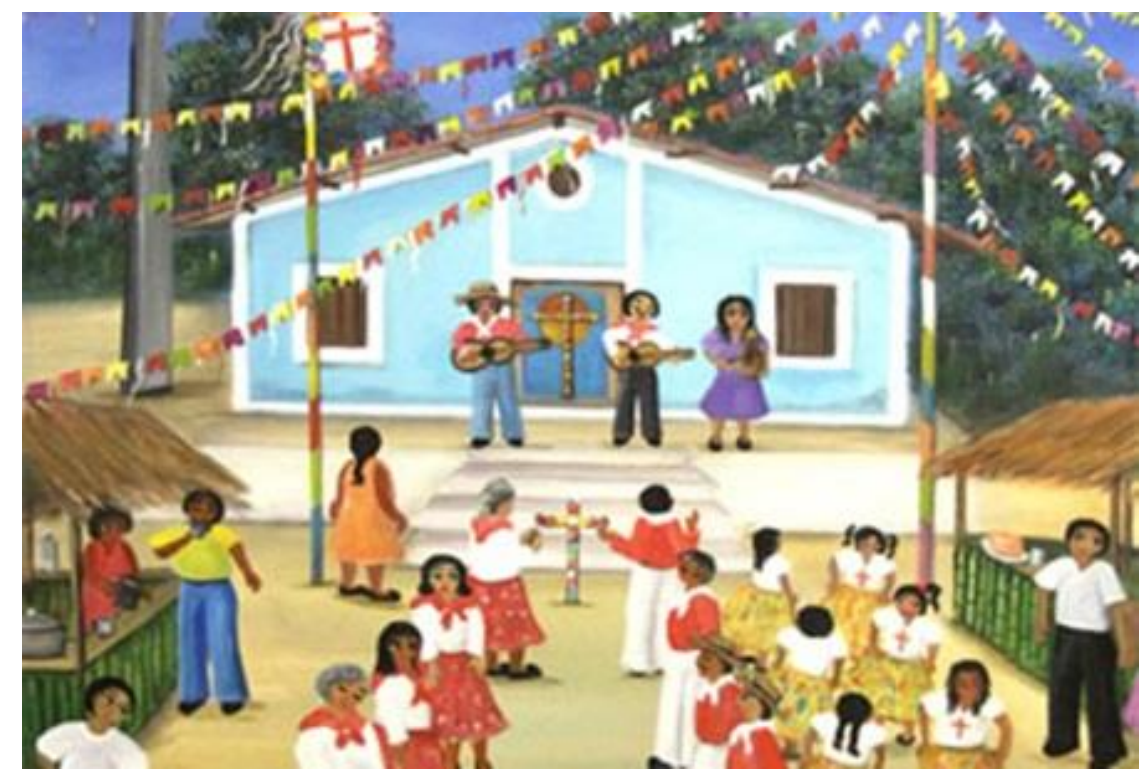

Figura 4: Cartaz da Festa de Santa Cruz em Carapicuíba Fonte: Pereira, 2011

\subsection{Moutinho, Steinen, Schmidt e Brasileiro}

Em Mato Grosso, encontramos os cronistas europeus da segunda metade do século XIX e início do XX a revelar aspectos da prática do Cururu que eram até então inéditos na literatura sobre o tema. 0 tom imprimido nestes testemunhos é geralmente o do estranhamento, o que resulta, em alguns casos, num juízo estético depreciativo e carregado de preconceitos em relação às culturas observadas. Mas é a partir deste olhar estrangeiro, um referencial cultural ainda mais distanciado das classes baixas da região, que a realidade musical do lugar torna-se visível. Deste modo, o português Moutinho e os alemães Steinen e Schmidt são os responsáveis pela principal etnologia do Cururu no período, posteriormente servindo de base, já na década de 1940, para o estudo de Francisco Brasileiro, também em Mato Grosso.

\footnotetext{
${ }^{19}$ ANDRADE, Mário de. Pequena história da música. Belo Horizonte: Itatiaia, 1980, p. 182. Este livro foi primeiramente editado em 1929, com título Compêndio da história da música.
} 
Em sua publicação de 1869, Joaquim Ferreira Moutinho refere-se ao Cururu como o "mais insípido e extravagante divertimento" existente em Mato Grosso, depois das danças indígenas. No círculo formado pelos folgazões, tomavam parte em sua maioria os homens, empunhando seus instrumentos (as violas-de-cocho, o adufe e o tambor), "volteando burlescamente" e cantando à porfia (desafio) suas cantorias. Como exemplo dos improvisos poéticos dos cururueiros, o cronista apresenta uma quadra em que um homem provoca em versos uma mulher, que responde com outra, em seguida, na mesma toada:

Eu passei o Parnahyba

Navegando n'uma barça,

Os pecados vêm da saia,

Mas não pode vir da carça.

Dizem que muié é farça

Tão farça como papé,

Mas quem vendeu Jesus Cristo

Foi home, não foi muiézo.

Karl von den Steinen, em seu relato de 1894, também descreve o início da "dança preferida do Mato Grosso" como o momento em que todos os presentes se posicionam em círculo, em torno da imagem do santo, cantando e dançando em seu louvor. A partir deste momento, o Cururu é cantado "em honra do rei e da rainha", personagens que se posicionam no centro da roda com uma garrafa de aguardente que é oferecida aos integrantes da roda ${ }^{21}$. Em seguida, é escolhido outro homenageado que faz o mesmo, também oferecendo um trago aos presentes, a partir do centro da roda. Segundo o viajante alemão, as toadas ouvidas tratavam de assuntos os mais variados, começando pelos cantos de devoção católica e seguindo

\footnotetext{
${ }^{20}$ MOUTINHO, Joaquim Ferreira. Notícia sobre a província de Mato Grosso seguida d'um roteiro da viagem da sua capital a S. Paulo. São Paulo: Typografia de Henrique Schroeder, 1869, p. 19.

${ }^{21}$ STEINEN, Karl von den. Entre os aborígenes do Brasil central. São Paulo: Dep. De Cultura, 1940, p. 711. O "rei e a rainha" citados por Steinen eram provavelmente os festeiros donos da casa, assim intitulados por terem sido eventualmente escolhidos também como rei e rainha do congado ou então por ter o autor se confundido em suas anotações a respeito das duas manifestações.
} 
com "os de amor, de zombaria e outros inventados conforme as inspirações do momento" 22 .

O Cururu observado por Max Schmidt nas festas de Rosário, em 1900, também iniciava com os devotos reverenciando as imagens de santos nas residências. Após a formação de um semicírculo diante do altar, o folguedo era conduzido pelos cantadores, que improvisavam ali mesmo os versos, acompanhados das violas-decocho e do caracaxá. Segundo Schmidt, os que tomavam parte na dança posicionavam-se inicialmente em duas filas, para formar em seguida um círculo fechado onde folgavam infatigavelmente até a madrugada, animados pelos movimentos da dança, pela novidade dos versos improvisados e o consumo da aguardente de cana. Estes são alguns dos versos do Cururu recolhidos pelo visitante alemão:

Lá la lá ia li la lão,

Lá la lá ia li la lão,

Já fui, já vim eu só

Lá no caminho de saudade de você

Quando lembrava de vós

Lá la lá la li la Ião,

Lá la lá la li la Ião,

Meu amor já foi embora

Eu não digo que eu não sinto

Mas chora por ele não

Ai, menina,

Quando mim vem em passeio

Me dá um aperto de mão

Eáh, eu mesmo!

Acende cigarro e me dá23

\footnotetext{
22 Ibidem, p. 711.

${ }^{23}$ SCHMIDT, Max. Estudos de etnologia brasileira: peripécias de uma viagem entre 1900 e 1901 . São Paulo: Cia. Ed. Nacional, 1942, p. 15.
} 
Através das estrofes transcritas por Schmidt, é possível inferir a presença, naquele canto ouvido há mais de cem anos, de alguns elementos encontrados no Cururu praticado hoje em Mato Grosso. 0 primeiro deles é o emprego de versos irregulares e sem rima. O segundo é o canto silábico de introdução, entoado normalmente em falsete (Lá-la-lá, lai-l,i la-Ião...), conhecido por baixão.

Outra importante referência é a do folclorista Francisco Brasileiro, em sua Monografia folclórica sobre o Rio das Garças, de 1947. Nela, o autor define o Cururu mato-grossense como uma "dança de roda, sem palmas e sem sapateado", com uma melodia pobre, porém de uma trama poética que exige "dos cantadores excepcionais qualidades de espírito" 24. Estrutura-se normalmente "em três tempos: louvação, bateção e perguntação", sendo assim explicadas:

1ํ) Louvação: ato de louvar o Santo da festa, motivo da reunião ou os donos da casa ou ainda algum personagem presente, convidado de honra. [...] 2º ) Bateção: ato de se por defeitos, criticar, "bater" em um dos presentes procurando ridicularizá-lo. Geralmente vem a ser um desafio. [...] 3ำ ) Perguntação: modalidade de desafio entre dois cantadores ou pergunta que fica, sem desafio, ao cuidado de qualquer cantador da roda responder ${ }^{25}$.

As conceituações de Francisco Brasileiro acerca da dança em Mato Grosso são, até onde sabemos, as primeiras feitas posteriormente aos relatos pioneiros de Moutinho, Steinen e Schmidt. Isto se levarmos em conta que João Ribeiro, em seu livro O folk-lore: estudos de literatura popular, de 1919, apenas reproduz os escritos de Max Schmidt publicados na Alemanha, em 1905. Trechos dos escritos de Brasileiro estão literalmente inseridos no verbete sobre a dança, no Dicionário do folclore brasileiro de Câmara Cascudo, dando-nos uma medida da contribuição pioneira deste autor para a etnologia do Cururu26.

\footnotetext{
${ }^{24}$ BRASILEIRO, Francisco. Monografia folclórica do Rio das Garças. Separata da Revista do Arquivo. São Paulo: Dep. de Cultura, 1951, p. 341. Apesar do título da monografia se referir ao folclore da região garimpeira do Rio das Garças, no leste do Estado de Mato Grosso, o Cururu relatado por Francisco Brasileiro é da região de Cuiabá.

${ }^{25}$ Ibidem, p. 341-2.

${ }^{26}$ CASCUDO, Luiz da Câmara. Dicionário do folclore brasileiro. Rio de Janeiro: Global, 2000 p. 226-7. Além do texto de Francisco Brasileiro, Câmara Cascudo utiliza em seu verbete trechos contidos em LIMA, Rossini Tavares de. Folclore de São Paulo: melodia e ritmo. São Paulo: Ricordi, 1978, 2a ed. p. 10-22.
} 


\subsection{Tavares de Lima, Maynard Araújo, Ikeda, Damante e Loureiro}

Dos autores que se dedicaram ao tema, a partir da década de 1940, a maior parte deles busca explicar as origens da dança através da hipótese levantada por Couto de Magalhães, segundo a qual o Cururu pertenceria à cultura dos índios antes mesmo da chegada dos colonizadores ibéricos e que teria sido apropriado e transformado pelos jesuítas em um instrumento de catequese. Estão entre estes autores Rossini Tavares de Lima (1954), o já citado Antônio Cândido (1956), Alceu Maynard Araújo (1949), Roberto Loureiro (2006) e Alberto Ikeda (2011). A exceção a esta hipótese é João Chiarini (1947), que acreditava ser o Cururu um folguedo trazido de Portugal, que aqui se misturou a elementos não europeus. Outros como Luís da Câmara Cascudo (1952) e Hélio Damante (1980), embora não se colocando contrários à opinião de Couto de Magalhães, tampouco se posicionam ao lado de Chiarini, limitando-se a apresentar os dois lados em seus trabalhos. A maioria destes autores também considera o Cururu em sua essência uma dança e não apenas uma cantoria. Isso, ao menos, em suas formas antigas, acompanhando, de certo modo, as descrições pioneiras de Cornélio Pires, Americano do Brasil e os cronistas estrangeiros do século XIX em suas próprias observações de campo.

Dos recursos usados por Rossini Tavares de Lima na conceituação da dança, destaca-se o testemunho de cururueiros antigos, tanto de Mato Grosso quanto de São Paulo. 0 folclorista cita, por exemplo, José da Silva de Piracicaba, que afirmava ser o cururu o nome em São Paulo para a dança de São Gonçalo, ilustrando sua informação com passagens atribuídas à vida do santo português ${ }^{27}$. Em Cáceres, no Mato Grosso, Tavares de Lima também anotou o relato oral de Joaquim Damasceno Silva, que dizia ser o Cururu "uma dança de roda, que gira pela direita", sendo a toada iniciada por um canto silábico conhecido como "baixão", seguido da "louvação", ambos puxados pelo cantador e seu "ajudante" (geralmente cantando numa terça acima ou numa terça ou sexta abaixo), terminando na "porfia" onde cada um dos cantadores não entoa mais que uma quadra e meia, a exemplo deste trecho:

\footnotetext{
${ }^{27}$ LIMA, Op. cit., p. 13.
} 
Pinga da festa cabô

Ogênio bebeu eu não bebi,

Sinha juíza venha vê

Tuiuiú com criquiri,

Eu entro debaxo de sua asa

E vô morre no tangurí28

Com Alceu Maynard Araújo, em seu artigo Cururu rural, temos uma descrição pormenorizada dos integrantes e os seus papeis na versão paulista do folguedo. Ao "pedreste" (sic), que é o cantador que não toma parte nos desafios, cabe ordenar a cantoria, propondo as "carreiras" (rimas) através da "arribada" ou da "licença" (canto introdutório) e sendo os demais cantadores, os "canturiões", encarregados da porfia, que é a etapa que se segue à louvação ao santo (esta também entoada geralmente pelo "pedreste"). Cantadores e instrumentistas tomam parte na dança, que é um dos elementos centrais na tipologia defendida por Maynard Araújo, a do Cururu rural.

0 cururu é uma dança de fundo religioso, geralmente realizada à noite na qual são cantados desafios dentro de um certo cânone, que se chama "carreira" ou "linha" e que é determinado pelo "pedreste". Embora dentro de um cânone, o canto é inteiramente improvisado, tendo o improvisador de acompanhar a viola, instrumento fundamental do cururu ${ }^{29}$.

Já o que seria, segundo a classificação de Maynard Araújo, o Cururu urbano, manifestação baseada apenas no desafio trovado entre os cantadores, tem na abordagem de Hélio Damante a seguinte definição:

$\mathrm{Na}$ verdade trata-se de um desafio entre violeiros, de uma forma caipira de repentismo, do que propriamente uma dança, pelo menos nas variantes que remanescem. Ocorre, porém, contar sempre com plateia atuante, a intervir com seus motes, a incentivar ou vaiar os cantadores, acompanhando-lhes o ritmo ${ }^{30}$.

\footnotetext{
${ }^{28}$ Ibidem, p. 11.

${ }^{29}$ ARAÚJO, Alceu Maynard. Cururu rural. In: Semana Nacional de Folclore. Rio de Janeiro: IBECC/CNF, 1949, vol 2, p. 66.

${ }^{30}$ DAMANTE, Hélio. Folclore brasileiro. Rio de Janeiro: INF/FUNARTE, 1980 p 30.
} 
Os principais locais onde o Cururu paulista é hoje praticado são os palcos dos teatros, cinemas e praças públicas, em torneios, mostras de cultura popular e programas de rádios locais. Cantando seus desafios diante dos microfones, os cururueiros não mais revivem através da dança e das trovas atos de devoção como os pousos do Divino e assim o seu caráter profano prevalece. Destas configurações mais recentes se ocuparam estudiosos como Alberto Ikeda.

O Cururu, pelo visto, sempre conteve este caráter de espetáculo cantado, já que grande ênfase se dava à capacidade de improvisação do cantador. Com a apresentação dessa modalidade nos palcos, fora das festividades religiosas onde normalmente era apresentada, esta passou a ser sua tônica. Aí está, portanto, o aspecto principal da sua nova função: espetáculo artístico baseado na cantoria de improviso. Ressalte-se, no entanto, que o Cururu não deixou de se fazer presente nas atuais festividades religiosas, porém não mais ligado à parte religiosa e sim ao aspecto profano festivo ${ }^{31}$.

O que, por fim, se destaca na observação atual do Cururu mato-grossense é a sua maior proximidade com o as representações do passado musical brasileiro. Uma manifestação cujos tons locais nos remetem a algumas das formas mais arcaicas, que são também localizadas em outras partes do Brasil. É com essa visão que Roberto Loureiro reafirma a tese da herança jesuítica no Cururu.

O Cururu é uma manifestação folclórica constituída de música e dança, que ocorre com esse nome, mas com variações na apresentação, nos estados de Goiás, São Paulo e, principalmente, em Mato Grosso. À época dos jesuítas, o Cururu era dançado, nos templos católicos, nos dias consagrados às festas de santos. [...] Executada por dois ou mais cururueiros, que cantam, dançando ou não, em dupla, em desafio à outra dupla, ou com mais parceiros, uma música de poucas notas, repetitiva $[\ldots]^{32}$.

\footnotetext{
31 IKEDA, Alberto. Cururu: resistência e adaptação de uma modalidade musical da cultura tradicional paulista. In Folias de reis, sambas do povo. São José dos Campos, SP: CECP/FCCR, 2011 p. 36. Neste ensaio, o autor também aborda o Cururu como gênero de canção sertaneja, cuja característica principal é a de manter, de forma estilizada, apenas a rítmica tradicional. Este aspecto das transformações ocorridas com o Cururu será abordado no Capítulo V desta tese.

32 LOUREIRO, Roberto. Cultura mato-grossense: festas de santos e outras tradições. Cuiabá: Entrelinhas, 2006, p. 73.
} 
Loureiro também ressalta o papel do Cururu nas práticas populares do catolicismo na região, como parte imprescindível das festas de santos nas zonas rurais. Este caráter ritualístico da dança do Cururu em Mato Grosso é sintetizado nas trovas transcritas abaixo:

Desde que entrei nessa casa,

Esqueci de louvar

Primeiro louvando o santo,

Segundo louvando o altar.

E quero tirar licença,

Permissão para brincar ${ }^{33}$.

\section{EM TORNO DO NOME}

A palavra cururu na língua tupi significa sapo grande e esta é, para muitos, também a etimologia do folguedo que leva o mesmo nome. A referida dança dos caboclos de São Paulo, Goiás e Mato Grosso seria, portanto, a dança do sapo, explicação que levou vários estudiosos do tema a considerá-la originalmente uma dança ritualística de povos indígenas deste tronco linguístico. Antônio Cândido respalda essa crença localizando a existência de representações míticas sobre a origem do fogo guardado por animais em tribos de diversos grupos como os Apapokúva-guarani do litoral paulista; os Carajá, Tapirapé e Guajajara da região do Araguaia e Maranhão; os Tapieté, Chiripá e Mbiá do chaco paraguaio e os Tumupása da Bolívia Oriental ${ }^{34}$. Sobre alegorias deste tipo, o etnólogo Herbert Baldus destaca que, nas tribos da grande família linguística Tupi, o roubo do fogo é sempre atribuído ao sapo, papel justificável pela capacidade que o animal tem de "engolir coisas ardentes como cigarros e brasas, talvez porque os tome por pirilampos". Baldus acrescenta ainda que as encenações dramáticas deste mito por ele testemunhadas incluíam danças imitando o sapo e o ato de fumar cachimbos e engolir brasas ${ }^{35}$.

Cândido menciona também o naturalista e botânico João Barbosa Rodrigues que, durante as missões científicas que empreendeu no estado do Amazonas, entre

\footnotetext{
${ }^{33}$ Ibidem, p. 75.

${ }^{34}$ CÂNDIDO, Op. cit., p. 387.

${ }^{35}$ BALDUS, Herbert. Ensaios de etnologia brasileira. São Paulo: Cia. Ed. Nacional, 1937, p. 213.
} 
1872 e 1887, registrou um canto do sapo entre tribos Tupi do rio Solimões. Ao que parece, não há uma relação direta do canto ouvido por Rodrigues com a dança caipira do centro-sul brasileiro. Diz respeito apenas à representação mítica do animal pelos nativos:

Yá munhan moracé

(vamos dançar)

Cururú (bis)

Cu çu cui chá icó,

(Aqui eu estou,)

Cururú (bis)

Cuchi ima cha ne cecare,

(Há muito tempo eu te procuro)

Cururú (bis)

Re pecêca ce cupé,

(Trepa minhas costas)

$$
\text { Cururú (bis) }
$$

Yá çu ya poracé,

(Vamos dançar)

Cururú (bis)

Cururú cunhan puchi

(Sapo fêmea feio)

Cururú (bis)

Cuire re cháre iché

(Agora tu me deixas)

Cururú (bis)

Cariva mirim pornga,

(O branquinho bonito)

Cururú (bis)

Cuçu cui ne ruca opé,

(Aqui está na tua casa)

Cururú (bis)

Tapiya tuyué,

(O tapuio velho)

Cururú (bis) 


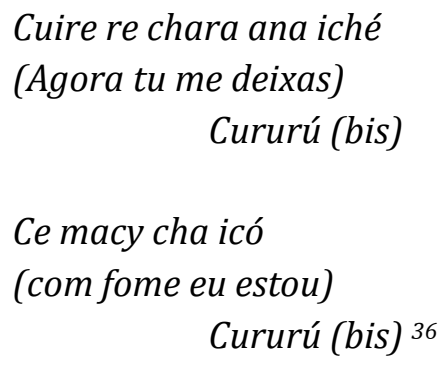

O jornalista e filólogo João Ribeiro também buscou nas práticas rituais indígenas explicações para as origens do Cururu. Em 1919, após tomar conhecimento da prática do Cururu em Mato Grosso, através de leituras como a dos estudos de etnologia de Max Schmidt, Ribeiro associou-as às cerimônias fúnebres dos índios Bororo, para ele chamadas de bacururu: "as palavras bacururu e cururu têm radicais comuns. Não é inverossímil que dos bororos tenha vindo o nome da dança do cururu" 37. Antônio Cândido contesta, no entanto, as conclusões de João Ribeiro:

Cururu é, como vimos, palavra tupi, e nada tem a ver com a referida cerimônia, cujo nome verdadeiro é "róia kurireu", ou "canto grande", iniciada com uma imprecação em que surge o nome de um dos heróis civilizadores dos Bororo, os gêmeos míticos Bakororo e Itubore: "a-a o-o Bakororo e Itubore". A transcrição defeituosa de João Ribeiro serviu de asa à sua imprudente conclusão ${ }^{38}$.

Outra explicação etimológica, que nos parece ser de todas a mais razoável, é a da deturpação da palavra cruz pelos índios submetidos ao catecismo e seus descendentes. Sérgio Buarque de Holanda nos fala da dificuldade que tinham os nativos, "mesmo após gerações sucessivas de contato com europeus, [em] falar corretamente língua de branco, dizendo curuzu ou curuçá, por cruz." 39 Palavras que foram logo incorporadas aos idiomas falados pelas tribos colonizadas e pela população de brasilíndios resultante deste processo, conforme atesta o glossário tupiguarani $^{40}$. 0 mesmo parece ter ocorrido na América espanhola, conforme a referência

\footnotetext{
${ }^{36}$ RODRIGUES, João Barbosa. Poranduba amazonense. Rio de Janeiro: Leuzinger \& filhos, 1890, p. 315-6.

${ }^{37}$ RIBEIRO, João. O folk-lore: estudos de literatura popular. Rio de Janeiro: Jacinto Ribeiro dos Santos, 1919, p. 230.

${ }^{38}$ CÂNDIDO, Op. cit., p. 388.

${ }^{39}$ HOLANDA, Sérgio Buarque de. Caminhos e fronteiras. Rio de Janeiro: José Olympio, 1957, p. 19.

${ }^{40}$ No léxico da língua tupi, a palavra que significa cruz é curussá ou curuçá. Na língua guarani, temos kurusu ou kuruxu. Cf. BARBOSA, Pe. Alemos. Pequeno vocabulário tupi-português. Rio de Janeiro: Livraria São José, 1967, p. 50. CUNHA, Antônio Geraldo. Dicionário histórico das palavras portuguesas de origem tupi. São
} 
de Eduardo Escalante à Fiesta de La Cruz ou Curuzu-Yeguá, que ocorre no mês de maio em várias regiões do Paraguai41. Outro exemplo é o de Mario Friedländer, que noticia em 2001 o cultivo em Porto Esperidião, município do oeste de Mato Grosso, de um folguedo de origem boliviana (mais especificamente, dos povos remanescentes das missões jesuíticas de Chiquitos) de nome curussét2. Friedländer explica que os chiquitanos que se espalharam por uma extensa área pertencente ao que hoje é o leste da Bolívia e a fronteira do Brasil, após o desmantelamento das missões jesuíticas no século XVIII, viveram uma segunda diáspora com a espoliação de suas terras, a partir da década de 1970, levando-os a formar comunidades nos arredores de cidades como Cáceres, Vila Bela e Porto Esperidião ${ }^{43}$. Surgiu assim a dança do curussé, manifestação popular derivada dos carnavalitos bolivianos que preserva, de algum modo, traços de uma herança jesuítica já apontada por Couto de Magalhães em 1897, ao se referir à Festa de Santa Cruz em São Paulo, Argentina, Paraguai e Bolívia44.

No processo natural de transformação e incorporação de palavras por outras línguas, a passagem de curuçá, curussé ou curuzu para cururu não parece ser uma hipótese distante.

\section{O INSTRUMENTAL}

Os instrumentos essenciais do Cururu de Mato Grosso são a viola-de-cocho e o ganzá, cabendo apenas aos homens a prerrogativa de tocá-los, segundo a tradição mais antiga. Maynard Araújo, referindo-se ao Cururu paulista, reproduz a fala do cururueiro João David que dizia não haver cururu sem viola ${ }^{45}$. 0 mesmo deve ser dito em relação ao Cururu mato-grossense e a viola-de-cocho (ou "cotcho", no jeito de falar da baixada cuiabana). Assim, nada mais justo do que iniciarmos esta seção com a descrição deste que é atualmente o instrumento símbolo da cultura local.

Paulo: Melhoramentos, 1989. Ver também: GAVILÁN, Diego. iGuarani: dicionário traductor guarani. Disponível em: < http://www.iguarani.com > acesso: 15/02/2015.

${ }^{41}$ ESCALANTE, Eduardo A. A festa de Santa Cruz da aldeia de Carapicuíba no estado de São Paulo. Rio de Janeiro: MEC-SEC/FUNARTE, 1981, p. 40.

42 FRIEDLÄNDER, Mario. “Curussé: uma tradição chiquitana” In: GRANDO, Beleni Saléte (org.). Cultura e dança em Mato Grosso. Cuiabá: Central de texto, 2005, p. 56.

43 Ibidem, p. 57.

${ }^{44}$ COUTO DE MAGALHÃES, Op. cit., p. 30.

${ }^{45}$ ARAÚJO, Cururu rural. Op. cit., p. 41. 
Ainda hoje confeccionada artesanalmente a partir do tronco escavado de árvores nativas da região (preferencialmente a ximbuva e o sarã), à maneira dos cochos de madeira inteiriça usados como repositório do alimento dado à criação animal, a viola-de-cocho tem despertado o interesse de artistas e etnógrafos, por sua forma, feitio e sonoridade sui generis. Ao braço e caixa de ressonância esculpidos no formato de pera, em uma peça inteiriça de madeira, juntam-se o tampo (uma lâmina fina, de raiz de figueira) e demais partes, como o cavalete, pestana, cravelhas e espelho (feitos em cedro). A cola usada na montagem das peças, que era feita originalmente da "poca" (a bexiga natatória de piranha), as cordas de tripa de macacos e os "pontos" ou trastes do espelho, em barbante de algodão com cera de abelha, são hoje produtos comprados, assim como as cordas aproveitadas das linhas de náilon utilizadas na pesca. Não obstante o uso atual de ferramentas e alguns materiais industrializados, os procedimentos empregados no seu feitio ainda guardam o saber tradicional das comunidades ribeirinhas e foram recentemente inscritos no conjunto de bens imateriais do Patrimônio Cultural do país ${ }^{46}$.

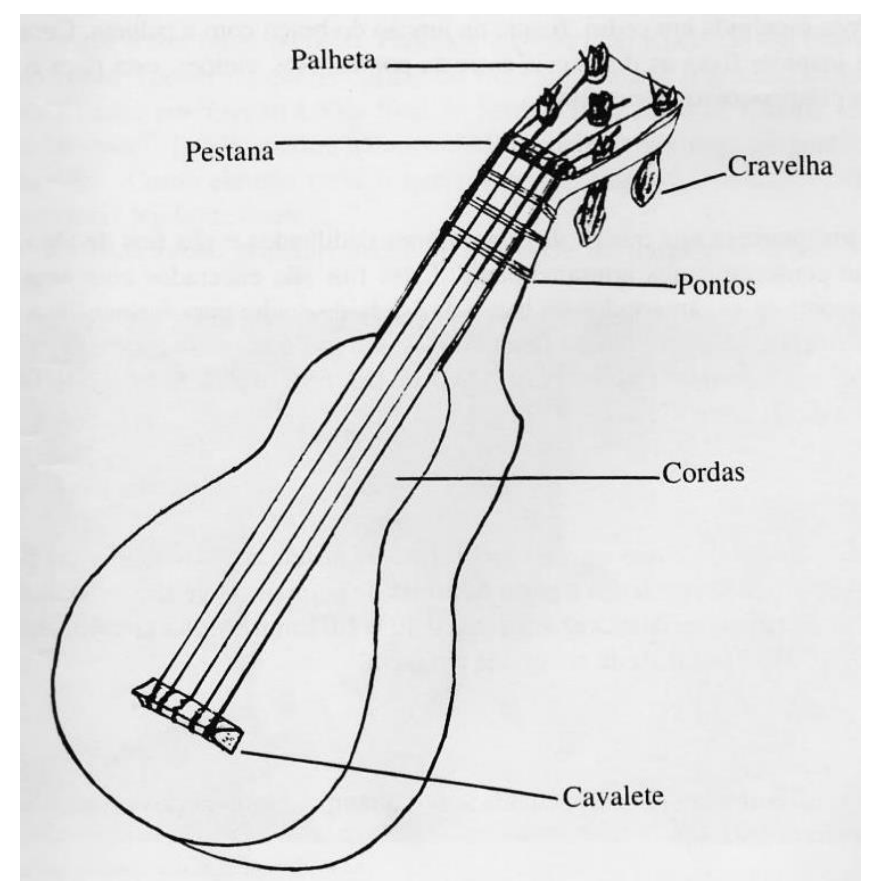

Figura 7: Partes da viola-de-cocho Fonte: Anjos, 1993

\footnotetext{
${ }^{46}$ VIANA, Letícia. "O caso de registro da viola-de-cocho como patrimônio imaterial", in Sociedade e Cultura. Goiânia: UFG, Vol. 8 N. 2, 2005, p. 53-62.
} 
Trata-se de um instrumento de cinco ordens simples de cordas dedilhadas, um braço curto com dois ou três "pontos" apenas (os mesmos trastes que definem a escala do violão e onde são montados os acordes pela mão esquerda do executante), do qual os violeiros extraem basicamente dois acordes, o da tônica e o da dominante (também o de subdominante, só que mais raramente) de uma escala maior, determinada pela altura em que é afinado o instrumento. As cordas são afinadas entre si de dois modos: "canotio" (canutilho) solto e "canotio" preso, conforme os exemplos abaixo:

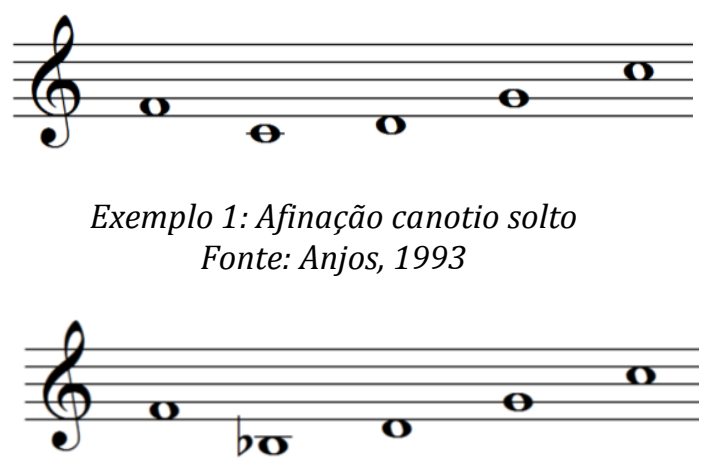

Exemplo 2: Afinação canotio preso Fonte: Anjos, 1993

Em relação aos golpes de mão direita, a viola-de-cocho pode ser rasqueada ou ponteada. No rasqueado, o conjunto de cordas é varrido ascendente e descendentemente com as unhas da mão direita, somando-se "ao som musical emitido, um leve ruído fricativo que integra a sonoridade do instrumento, individualizando-lhe o timbre." $47 \mathrm{Na}$ técnica do ponteado, cordas isoladas são feridas com a ponta dos dedos da mão direita, desenhando linhas melódicas instrumentais ${ }^{48}$.

Os caminhos trilhados pela viola-de-cocho rumo à sua adaptação a condições específicas do pantanal e do cerrado mato-grossenses fizeram parte do processo de difusão da cultura ibérica na região. Acredita-se que o instrumento (ou algum outro da mesma família das violas dedilhadas) tenha sido trazido pelos sertanistas que ali se estabeleceram a partir das expedições bandeirantes vindas de São Paulo, individualizando-se no nome e nos modos de fazer e tocar. É possível que a sua

\footnotetext{
${ }^{47}$ ANDRADE, Julieta de. Cocho mato-grossense: um alaúde brasileiro. São Paulo: Escola de Folclore/Editorial Livramento, 1981, p. 32.

48 Ibidem, p. 33.
} 
difusão na região também tenha ocorrido por intermédio das missões católicas portuguesas e espanholas, tornando-o característico de lugares com forte herança ameríndia. Buscando explicar a gênese desta viola-de-cocho pantaneira, a pesquisadora Julieta de Andrade compara a sua forma à dos alaúdes árabes que se espalharam pela Europa, trazidos pelos mouros que ocuparam a Península Ibérica, do início no século VIII até o final da Idade Média. A novidade destes cordofones dedilhados, cujas notas podiam ser modificadas pela pressão dos dedos no braço do instrumento, fez surgir por toda a Europa uma enorme variedade de guitarras e violas, especialmente entre os povos mediterrâneos. A autora conclui através da organologia da viola-de-cocho que a mesma

pertence ao ramo de alaúdes muito curtos que apareceram, pela primeira vez, no Irã, entre os elamitas, [percorrendo] desde logo [...] longa caminhada através de culturas asiáticas, depois européias e norte-africanas. Pelo nomadismo, ciganos, kirguises e principalmente árabes contribuíram para a difusão dos alaúdes através do Velho Mundo. [...] Os dois ou três pontos móveis da viola de cocho sugerem ligação com o ramo da chamada guitarra mourisca [...] e o mesmo elemento aproxima ambos os instrumentos do alaúde de Florença, do século X e do exemplar de Amiens, do século XIV49.

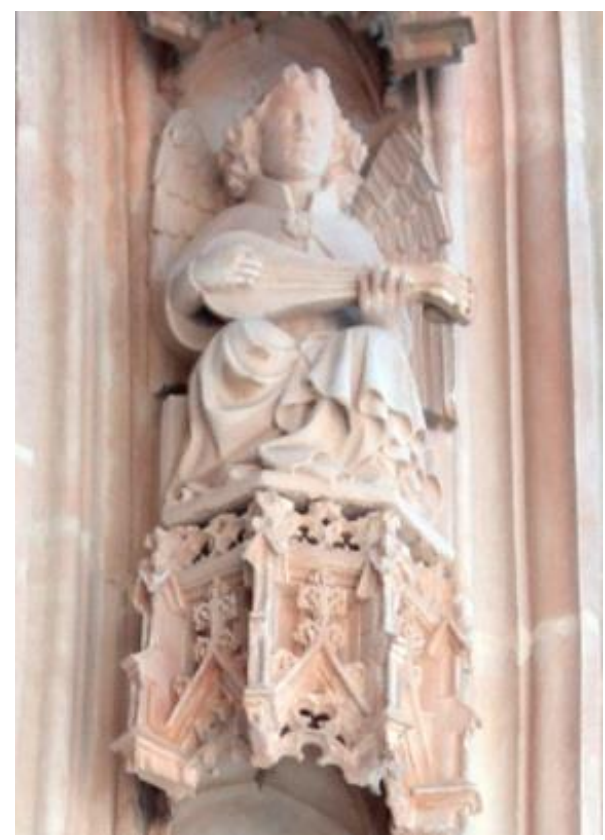

Figura 9: Detalhe do pórtico do Mosteiro da Batalha Fonte: Lupii, 2013

${ }^{49}$ Ibidem, p. 72-3. 
Abel dos Anjos localiza outro parentesco distante no tempo, com a viola-decocho: a guitarra latina utilizada na arte trovadoresca da Europa do século XIII. Ao analisar esculturas do século XIV no pórtico do Mosteiro de Santa Maria da Vitória, na Vila da Batalha em Portugal, o pesquisador encontrou representações bastante parecidas com o instrumento brasileiro (figuras 8 e 9). Entre elas, a guitarra latina, que prefigurou, segundo Vilela, o formato da vihuela ibérica e deu origem às violas de mão portuguesas surgidas a partir dos séculos XV e XVI: a viola braguesa do norte, a viola beiroa e amarantina do centro e do nordeste do país, bem como as violas toeira e campaniça mais ao sul50. Entrevistando construtores de instrumentos e historiadores em Portugal, Anjos identificou técnicas artesanais comuns aos dois países, como o uso da cola de víscera de peixe e o cravelhame inclinado. Também encontrou terminologias afins como mocho e adufo (nomes de instrumentos que, no passado, também participavam do Cururu), assim como o emprego de sistemas de afinação similares 51 .

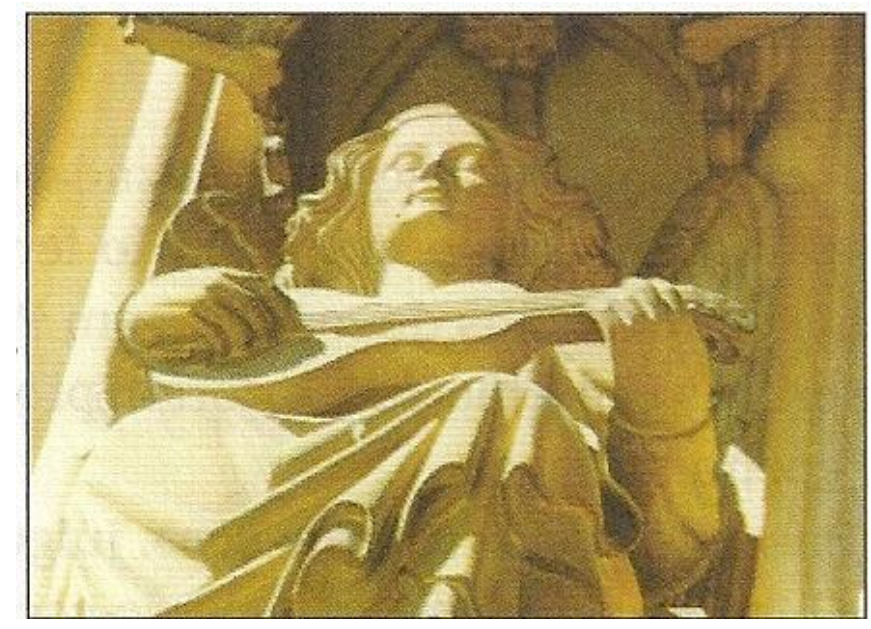

Figura 8: Mosteiro da Batalha, Portugal Fonte: Anjos, 2002

Outro instrumento atualmente empregado no Cururu de Mato Grosso é o ganzá ou caracachá. Trata-se de uma espécie de reco-reco feito de taquara, com cerca de $50 \mathrm{~cm}$ de comprimento, onde são aplicadas ranhuras ou sulcos transversais. Para tocá-lo, fricciona-se longitudinalmente a taquara com uma pequena vareta de madeira ou um pedaço de osso (geralmente uma costela bovina ou suína), no local

\footnotetext{
${ }^{50}$ VILELA, Ivan. Cantando a própria história. Tese de doutorado. São Paulo: USP, 2011, p. 117-8.

${ }^{51}$ ANJOS FILHO, Abel Santos. Uma melodia histórica: eco, cocho, cocho-viola, viola-de-cocho. Cuiabá: SEC, 2002, p. 114-6.
} 
onde foram feitas as ranhuras. São também feitas duas ou três rachaduras no bambu, para que o som produzido pelo ganzá seja amplificado. Em uma roda de Cururu, participam normalmente mais de um ganzá, mesmo sendo o seu volume sonoro mais elevado que o das violas.

No passado, o adufe ou adufo também fazia parte do Cururu. Feito de couro de veado, cotia ou carneiro, este tipo de pandeiro podia ter ou não as platinelas de metal. Ainda presente nas folias-de-reis, congadas, fandangos e em algumas danças de Santa Cruz e São Gonçalo, o adufe deixou de ser empregado no Cururu mato-grossense por não ser mais confeccionado artesanalmente ${ }^{52}$. Além da viola-de-cocho, dos ganzás e do adufe, outros instrumentos foram associados ao Cururu, conforme alguns registros de práticas mais antigas. Moutinho relata em sua crônica o uso do tambor (provavelmente o tamboril, ainda empregado no Siriri cultivado em Mato Grosso do Sul) ${ }^{53}$. Steinen, por sua vez, cita a viola de arame, além da marimba e o tambaque, dois dos instrumentos associados à música dos negros ${ }^{54}$. Francisco Brasileiro menciona 0 uso inusitado de rabecas, além do acompanhamento das violas e reco-recos ${ }^{55}$. Por serem menções isoladas, não é possível assegurar que no passado tenha havido uma efetiva incorporação destes instrumentos nas práticas do Cururu na região. Elas podem indicar apenas uma proximidade maior do cultivo do Cururu com outros gêneros de canto e dança.

0 instrumental no Cururu paulista tem características parecidas. $\mathrm{Na}$ manifestação rural descrita por Maynard Araújo, os três instrumentos indispensáveis são a viola de arame (também conhecida por viola caipira), o adufe e o reco-reco ${ }^{56}$, tendo sido também registrada pelo autor a presença do "cocho", na área rural do município de Tietê, em 194757. Outra modalidade de viola de arame empregada no gênero paulista é também descrita por João Chiarini: o "mocho", ou "mochinho", de braço mais comprido, corpo mais afilado e timbre mais agudo ${ }^{58}$. Cornélio Pires também menciona o trio composto pela viola, o reco-reco de bambu e o adufe, além

\footnotetext{
${ }^{52}$ VIANNA, Letícia. Dossiê Iphan 8: modo de fazer viola-de-cocho. Brasília: Minc/Iphan, 2009, p. 26.

${ }^{53}$ MOUTINHO, Op. cit., p. 18.

${ }^{54}$ STEINEN, Op. cit., p. 711.

${ }^{55}$ BRASILEIRO, Op. cit., p. 341.

${ }^{56}$ ARAÚJO, Cururu rural. Op. cit., p. 42.

${ }^{57}$ Ibidem, p. 36.

${ }^{58}$ CHIARINI, Op.cit., p. 100.
} 
de acrescentar a puíta (o mesmo que cuíca) e o pandeiro ${ }^{59}$. Já nas modalidades mais recentes, sem a dança e com ênfase no desafio poético, os instrumentos acompanhantes são a viola caipira e o pandeiro; em muitos casos, apenas a viola.

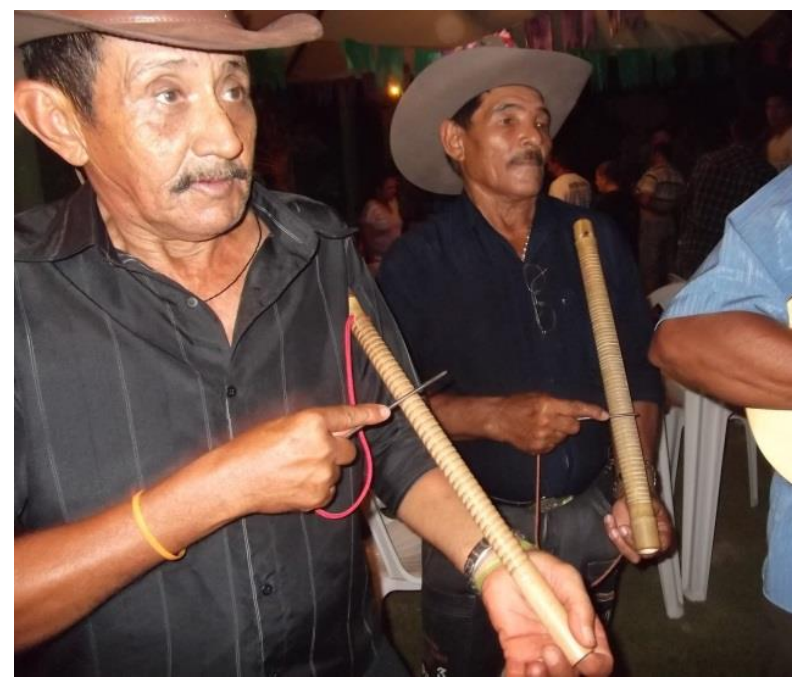

Figura 10: Tocadores de ganzá Fonte: Reis, 2013

\section{MÚSICA E POESIA}

Os autores que escreveram sobre o Cururu cultivado em Mato Grosso são quase unânimes em afirmar que a linha melódica empregada nas canções é geralmente caracterizada pela simplicidade das frases curtas e dos pequenos intervalos melódicos. Loureiro refere-se a esta música como sendo repetitiva e de poucas notas, "acompanhada pelo ritmo marcado pelas violas de cocho e ganzás [...], em uma voz anasalada, muito difícil de ser entendida por quem não é da região". 60 Martins Júnior também menciona o modo "anasalado e lamuriado" dos cururueiros, cantando suas toadas em duas vozes com uma pronúncia quase indecifrável ${ }^{61}$. Em relação à sua poesia, também prevalece a noção de singeleza e espontaneidade, expressa na ausência de uma uniformidade métrica para os versos (chamados de "pés" pelos cururueiros) e na não obrigatoriedade do uso da rima. Sobre isso, o maestro e educador musical Jeferson Ribeiro, morador de Santo Antônio de Leverger, comenta que uma das principais distinções do Siriri em relação ao Cururu da região é

\footnotetext{
${ }^{59}$ PIRES, Op. cit., p. 109.

${ }^{60}$ LOUREIRO, Op. cit., p. 73.

${ }^{61}$ MARTINS JÚNIOR, Moisés Mendes. Revendo e reciclando a cultura cuiabana. Cuiabá: Janina, 2006, p. 82.
} 
que o primeiro se configura no que ele chama de "poesia musicada", enquanto o segundo seria uma espécie de "prosa em música" 62.

Outro elemento importante nos Cururus de Mato Grosso e São Paulo é o já mencionado canto monossilábico que antecede os versos da toada. Eduardo Escalante, em seu estudo sobre o Cururu no Médio Tietê, assim explica este trecho chamado baixão: "é o canto que antecede o desafio, espécie de preparação, sem versos, cantado sobre os monossílabos 'ai', 'lai' e 'nai' geralmente" 63. Em partes de Mato Grosso, o baixão é conhecido apenas como o arremate da cantoria, quando os cururueiros entoam notas agudas ao final, geralmente a fundamental do acorde da tônica (uma oitava acima), juntamente com uma terça ou uma sexta. Loureiro referese ao baixão como o "grito prolongado, emitido pelos cantores, ao finalizar um trovo, toada ou carreira" 64 .

Algumas dessas características podem ser vistas através dos três exemplos musicais selecionados para este capítulo. 0 primeiro é um Cururu profano em Ré maior, de autoria do Sr. Aluísio Silva, por mim registrada e transcrita em junho de 2011, na Comunidade Mutuca, localizada no município de Nossa Senhora do Livramento (exemplo 3, faixa 1 do CD em anexo). Cinco pequenas frases musicais compõem esta toada, com as suas figuras rítmicas determinadas pelas sílabas das palavras, à maneira dos cantos recitativos. A sequência harmônica em cada uma das frases é: $V_{7}$ - I (sétima da dominante para a tônica, do primeiro compasso com anacruse à primeira metade do compasso 2), I - IV (tônica para subdominante, do compasso 3 ao 5), V - I (dominante para tônica, entre os compassos 6 a 9, com anacruse), I - V (tônica para dominante, do segundo tempo do compasso 9 para o primeiro tempo do compasso 13), IV - V - I (subdominante, dominante e tônica, da anacruse do compasso 20 ao final).

\section{(Ai, avisa na Mutuca \\ Vai viver a geração, ai...) \\ Óia o mundo como anda \\ O povo tá diferente demais}

\footnotetext{
62 Depoimento gravado concedido ao autor em agosto de 2014.

63 ESCALANTE, Eduardo. A música no Cururu do Médio Tietê paulista. Dissertação de mestrado. São Paulo: ECA/USP, 1986, p. 52

${ }^{64}$ LOUREIRO, Op. cit., p. 74.
} 
É pai brigando com filho,

Filho brigando com a mãe.

É o cumpadre com a cumadre,

[que] tá ficando malquerençado um com o outro

Dispois, pega a reclamar

Que o mundo num anda bão,

Mas ruim é o povo

Que num tem mais união

(E já vou deixar meu verso,

que entrego na vossa mão)
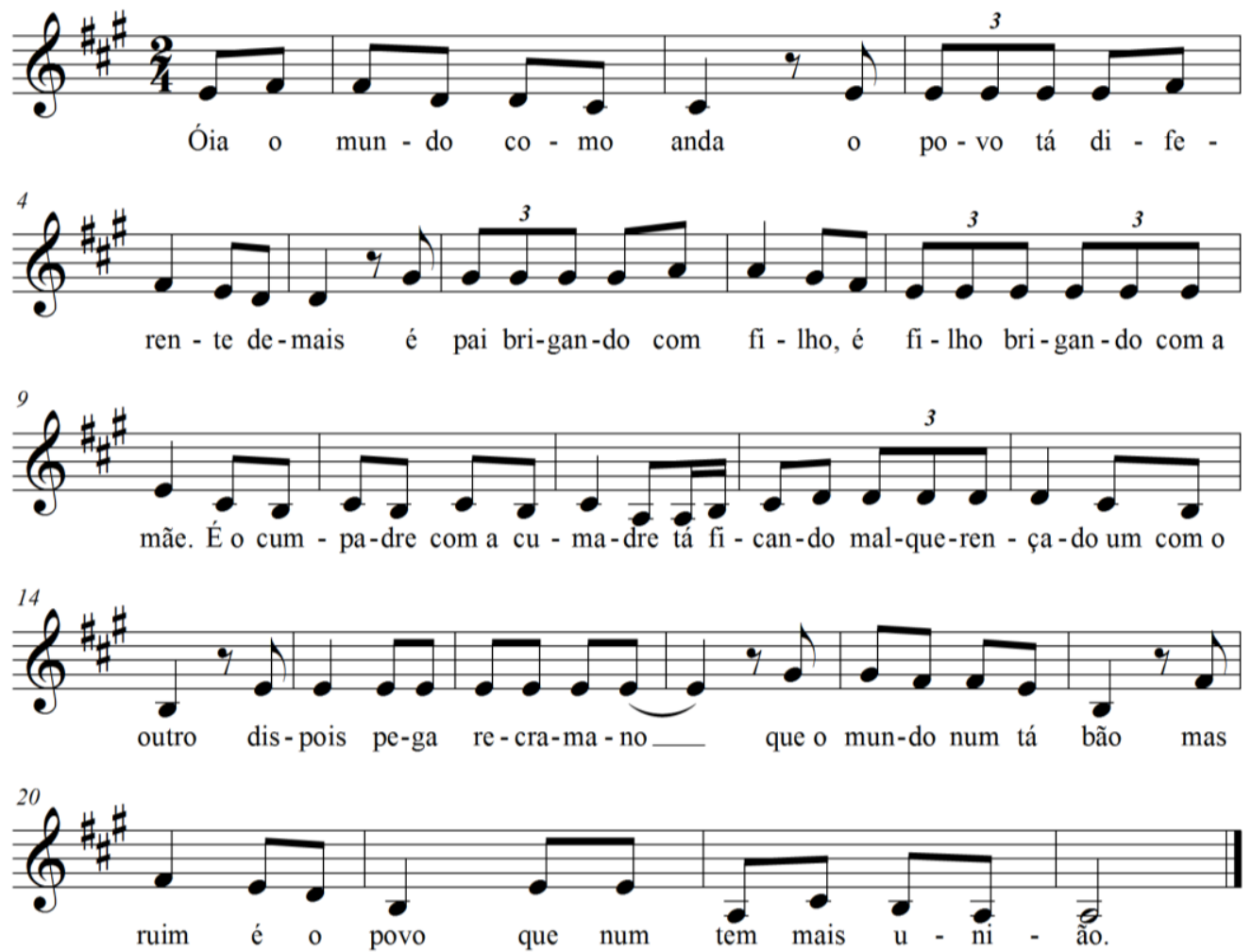

Exemplo 3: Toada de Cururu

(Aluisio Silva)

Fonte: o autor 
A letra é estruturada em três estrofes, sendo a primeira uma quadra em redondilha maior sem rimas. A segunda em versos livres e a terceira uma quadra em versos hexassílabos, com rimas alternadas nos segundo e quarto versos. 0 "improviso" nesta toada se restringe à inclusão, no início do canto, do trecho "Ai, avisa na Mutuca, vai viver a geração, ai..." e, ao final, "E já vou deixar meu verso, que entregou na vossa mão". São, na verdade, pequenas frases ou fragmentos prontos, adaptados à ocasião, não havendo longos improvisos, como na modalidade paulista.

O segundo exemplo é um trecho de uma carreira de santidade, cantada pelo Sr. Lourenço Ferreira Mendes, também registrada e transcrita por mim em 2011, no município de Cáceres (exemplo 4, faixa 2 do CD em anexo). Este é um Cururu que era praticado pelo seu padrinho que lhe ensinou a arte da cantoria. Assim como a anterior, trata-se uma melodia na tonalidade maior (Mi bemol), no compasso binário simples. As frases musicais seguem o padrão rítmico de colcheias repousando em semínimas, sendo as três primeiras com a extensão de dois compassos e as duas últimas com três e quatro compassos, respectivamente. Na harmonia, alternam-se os quinto e primeiro graus apenas. A primeira estrofe é uma quadra em redondilha maior e a segunda um dístico em versos livres. Sr. Lourenço Mendes explica que, antes desta carreira, o cururueiro deve "louvar" ao santo e aos presentes e, após a mesma, pedir a "licença" para continuar "brincando" o Cururu, sempre em forma de canto.

Jesus esteve em Galiléia,

Somente ele suspirava,

Rei Herodes perguntou:

"Mas tu também é Rei da Judéia?"

Jesus disse: "eu sou,

Mas eu sou Rei lá de meu Reino". 


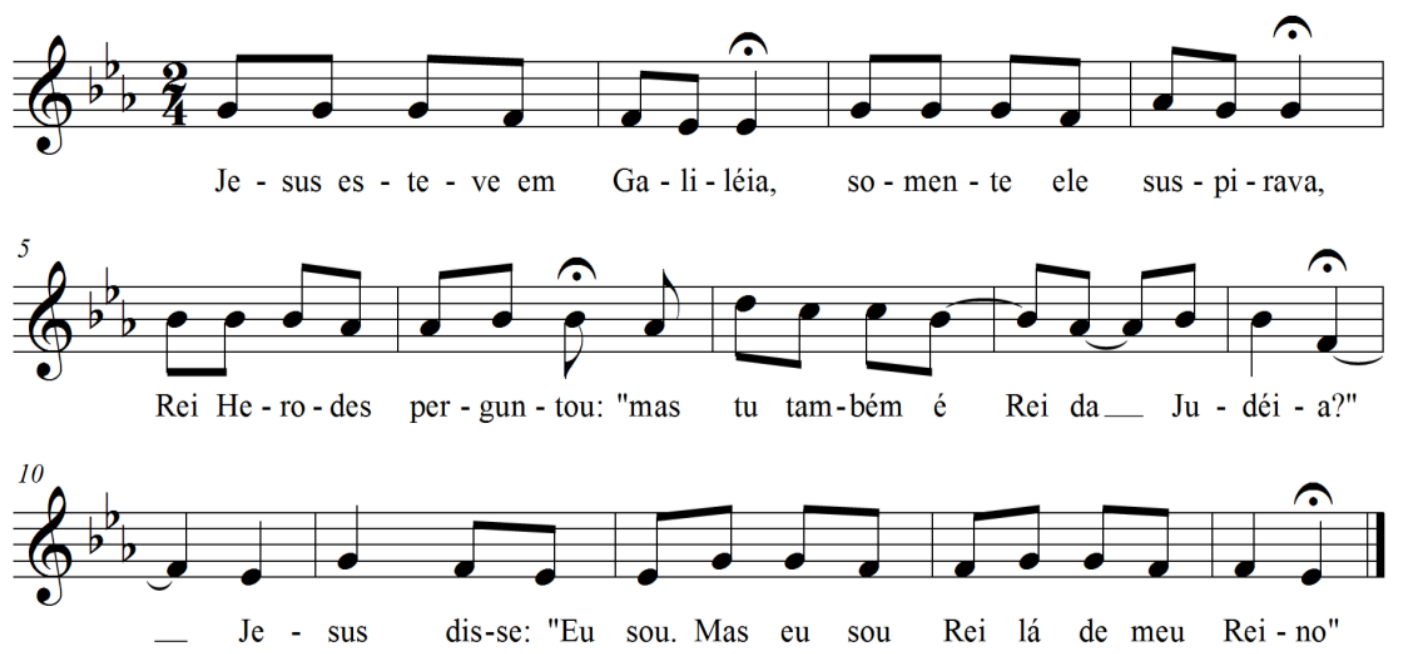

Exemplo 4: Toada de Cururu

(Lourenço Ferreira Mendes)

Fonte: o autor

A última toada, cantada por Miguel Arcanjo de Souza e companheiros, teve o seu registro feito por Elisabeth Travassos e Roberto Corrêa, em Poconé, no ano de 1987, e transcrito por Edilberto Fonseca, em 2009 (exemplo 5, faixa 3 do CD em anexo). É cantada, como nos exemplos anteriores, na tonalidade maior, quase toda a melodia em terças paralelas, sendo a escolha da tônica em Mi feita em razão da afinação das violas dos cururueiros nesta altura. A esse respeito, Abel dos Anjos, explica que os violeiros, em sua maioria, não fazem uso de um diapasão para afinar seus instrumentos; guardam na memória a distância sonora correta entre as cordas, "escolhendo" uma determinada altura sobre a qual as cordas são ajustadas (como nas afinações canotio solto e preso, demonstradas nos exemplos 1 e 2) ${ }^{65}$. Nesta toada, as três frases musicais progridem harmonicamente do seguinte modo: I - V, V - IV - V I, I - V - I.

A poesia neste caso tem a métrica inteiramente livre e o assunto é variado. Mesmo sendo o tema de caráter predominantemente profano (a saudade do homem viajante que, ao chegar àquela localidade, se impressiona com a beleza de uma moça e sonha com a volta trazendo um presente), o canto também trata, em poucos versos, de fazer a saudação aos presentes e acompanhar o capelão na hora de rezar.

\footnotetext{
${ }^{65}$ ANJOS, Abel dos. Viola-de-cocho:novas perspectivas. Cuiabá: EdUFMT, 1993, p. 22.
} 
Venho vindo lá de longe, ai ai.

Eu vim só pra passear

Ai, moça morena

Eu não esqueço d'ocê

Eu quero lhe dar um presente

$A i$, moça

Pra quando eu voltar pra Cuiabá.

Vou saudar meu pessoal, ai ai.

E ao senhor dono da casa

Homilia do capelão, ai ai.

É hora de nóis rezar.
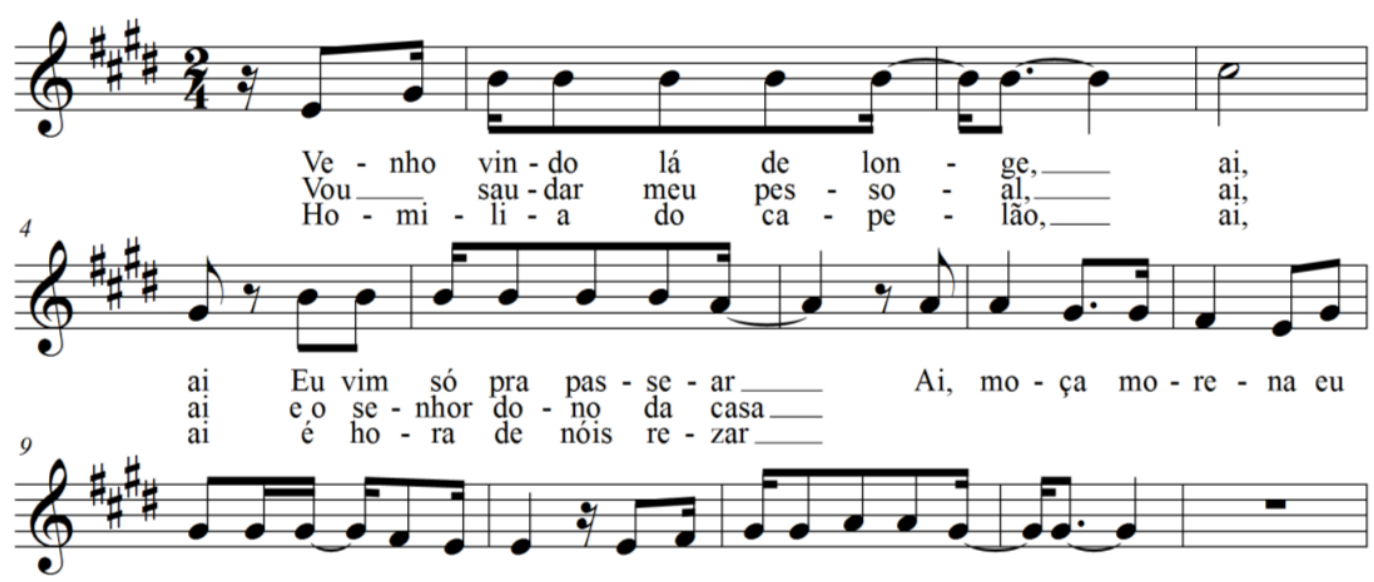

não es-que - ço d'o - cê E a sau - da-de vai co-mi - go

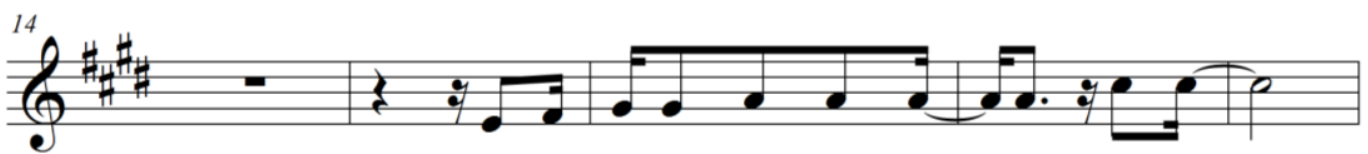

Eu que - ro lhe dá um pre - sen - te $\mathrm{Ai}, \mathrm{mo}$

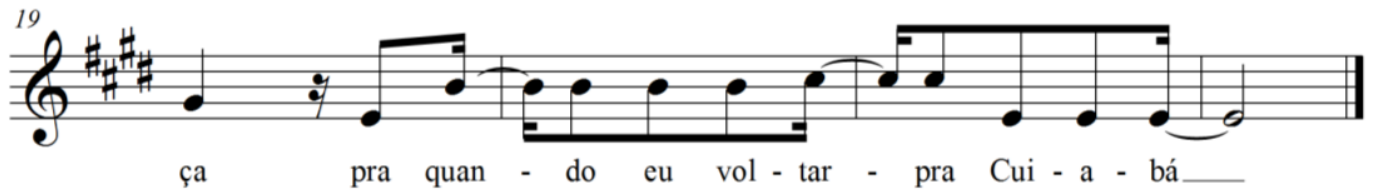

Exemplo 5: Toada de Cururu

(Miguel Arcanjo de Souza e outros)

Fonte: Travassos, Corrêa e Fonseca, 2009 
Os cururueiros executam normalmente em suas violas apenas dois acordes: os de dominante e de tônica (ver figura 11), ainda assim, sem que estes mesmos acordes coincidam obrigatoriamente com a progressão harmônica determinada pela linha melódica. Em outras palavras, os acordes são muitas vezes tocados nos lugares harmonicamente "errados", sendo este suposto "erro" responsável por produzir um efeito estético-sonoro bastante peculiar, aproximando o Cururu da sonoridade monocórdica dos cantos indígenas. Este traço de rusticidade presente na música dos ribeirinhos, que faz com que as cordas da viola-de-cocho produzam um efeito mais percussivo que harmônico, tem sido frequentemente alterado por músicos de diferentes nichos, com a transposição de seu sotaque para outros ambientes e outras formações instrumentais. É por isso que alguns dos experimentos feitos no âmbito da música popular de massa, da música de concerto, ou mesmo do folclore adaptado ao formato do espetáculo, que buscam incorporar em suas leituras elementos musicais do Cururu e do Siriri, são incapazes de reproduzir o sabor ameríndio ouvido na cantoria das festas tradicionais dos caboclos da região66.

\section{TÔNICA}

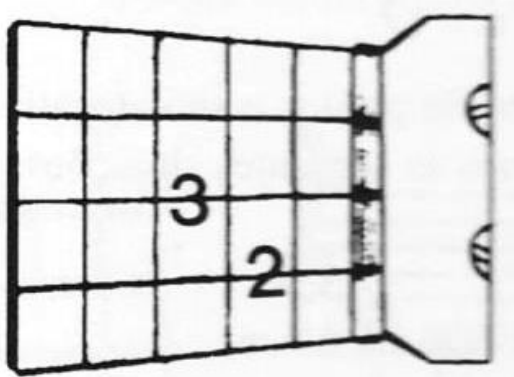

DOMINANTE

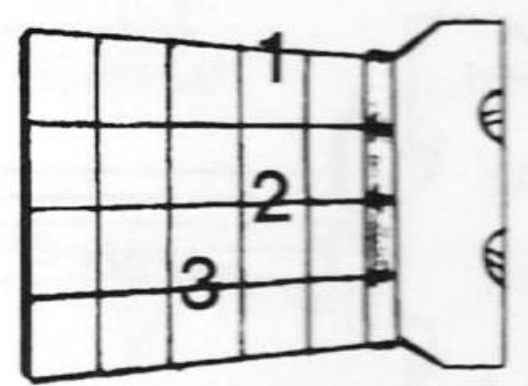

Figura 11: Acordes na viola-de-cocho (tablatura)

Fonte: Anjos, 1993

\footnotetext{
${ }^{66}$ Os fenômenos de apropriação e ressignificação da prática do Cururu e do Siriri pelas culturas de massa e erudita serão tratados no capítulo $\mathrm{V}$ desta tese.
} 
Outro detalhe a ser observado nos três exemplos musicais selecionados é a rítmica que as cadencia, a chamada "batida" do Cururu. A figura empregada no acompanhamento destas toadas é uma das que caracterizam a dança: uma colcheia pontuada seguida de semicolcheia, repetidas em cada um dos tempos do compasso (exemplo 6).

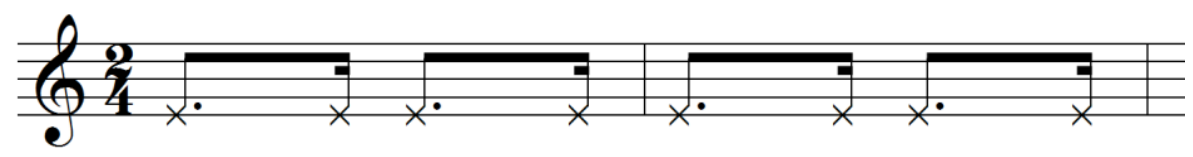

Exemplo 6: Um dos ritmos tradicionais do Cururu Fonte: o autor

\section{COREOGRAFIA}

Nas celebrações religiosas o Cururu é dançado após os seus membros cumprirem a "obrigação" para com o santo e as pessoas importantes naquela ocasião. Iniciam o canto com a "louvação", pedindo licença e prestando homenagem aos oragos do altar, aos donos da casa e demais convidados ilustres. Neste momento, posicionam-se em fila dupla ou em semicírculo, realizando também gestos individuais como a inclinação do tronco para frente e a genuflexão. Passa-se, em seguida, à dança propriamente dita com a formação de uma roda na qual o grupo, em fila única, se movimenta no sentido horário. Sobre os passos executados na roda, não há muitos detalhes a serem descritos: dois passos mais longos (marcando o tempo forte e sua subdivisão, no compasso binário da música), seguidos de dois passos curtos que se assemelham a uma parada (correspondendo ao tempo fraco ou segundo tempo deste mesmo compasso binário). Há também o momento em que o Cururu se torna mais animado e alguns dos dançarinos fazem meneios livres com o corpo, ajoelhando e rodopiando enquanto cantam e tocam. São "volteios burlescos", nas palavras de Moutinho ${ }^{67}$, que poderiam ser considerados os solos dos cururueiros, que o fazem um de cada vez ou em duplas, às vezes se dirigindo ao centro da roda.

Roberto Loureiro, que vivenciou desde menino a tradição das festas rurais de santos, na baixada cuiabana e pantanal, assim define a dança em Mato Grosso:

\footnotetext{
${ }^{67}$ MOUTINHO, Op. cit., p. 18
} 
A dança consiste em fechar um círculo de dançarinos em fila única, rodando estes, invariavelmente, no sentido do braço das violas horário. A coreografia se resume em dar dois passos mais longos à frente, uma breve parada, juntando os dois pés, para depois repetir os passos, balançando o corpo no ritmo dos sons dos instrumentos com a marcação dos pés produzindo um único ruído.

0 homem que quiser entrar na roda deve fazê-lo sempre atrás do participante que estiver cantando, para manter a ordem e o ritmo do bailado. Há cururueiros, que, nas horas mais animadas da dança, sapateiam fortemente, gingando de forma diferente, dando meiasvoltas ou se ajoelhando, sem jamais perder a marcação ${ }^{68}$.

Martins Júnior também menciona estes momentos mais animados da dança, com a intervenção no centro da roda de alguns dos cururueiros que sapateiam mais fortemente e volteiam em torno de si mesmos, acrescentando uma nova sonoridade ao conjunto dos instrumentos, para depois voltarem à dança "arrodeada" com os demais. "Gingam de forma diferente dando mais voltas, porém sem perderem a marcação, para não ofenderem a coreografia" 69 .

Eunice Rocha completa a descrição do sapateado no Cururu afirmando ser o mesmo uma parte de destaque na coreografia. Para a pesquisadora, este é o momento de total concentração e envolvimento dos dançarinos com a música e o espírito religioso, correspondendo ao estado de êxtase observado em diversas práticas rituais que utilizam a dança:

O sapateado não é um simples bate-pé, mas forma um conjunto harmônico, uma coreografia, onde as pessoas se entrecruzam mas não se chocam, onde os joelhos quase tocam o chão ao mesmo tempo em que o tronco se desloca, rapidamente, ora para a direita, ora para a esquerda, um ao contrário do outro, numa alternância tão sincronizada, que não perdem o equilíbrio, nem se esquecem de dedilhar as violas que, nesse momento, ficam um pouco mais presas contra o peito. No sapateado podemos sentir através da magnitude do entusiasmo, uma completa liberação do corpo. As fisionomias se iluminam refletindo um sentimento de realização e de satisfação interior ${ }^{70}$.

\footnotetext{
${ }^{68}$ LOUREIRO, Op. cit., p. 75

${ }^{69}$ MARTINS JÚNIOR, Op. cit., 83.

${ }^{70}$ ROCHA, Eunice Ajala. Uma expressão do folclore mato-grossense: Cururu em Corumbá. Dissertação de mestrado. Porto Alegre: PUCRS/BCE, 1981, p. 35. Vale observar que o sapateado no Cururu não é o mesmo que se que apresenta no cateretê ou em alguns dos fandangos praticados nas províncias do sul. No Cururu não há o pateio alternado com palmas característico da catira, que tem a sua função percussiva amplificada pela execução em um tablado. Tampouco se assemelha ao sapateado rufado de fandangos como a tirana, o
} 
A dança no Cururu na região paulista do Médio Tietê está desaparecida, restando apenas a modalidade de desafio cantado ao som da viola caipira. Em uma das pesquisas de campo em que foram observados exemplos derradeiros do gênero cultivado com dança e com sentido religioso, Maynard Araújo obteve informações que revelam alguns dos aspectos mais arcaicos da dança que permaneceram vivos na manifestação mato-grossense. Embora descrito de um modo um tanto confuso, o Cururu rural observado por Araújo na década de 1940 era basicamente uma dança circular, com pouquíssimas variações, que girava preferencialmente no sentido dos ponteiros do relógio:

A dança constitui-se de movimentos lentos, de mudança de passos para frente e para trás. 0 passo dado à frente é sempre maior, quase o dobro do que é dado para trás, isso no caso do "canturião", porque o "segunda", que fica defrontando o improvisador, executa inversamente tais deslocamentos. Há perfeita sincronização nesse movimento, pois quando o canturião avança um passo para a frente, o "segunda" recua um passo, quando o "canturino" vem a ré um passinho, o "segunda" adianta-se um passinho. Os demais componentes da roda seguem, andando sob o ritmo do canto do "canturião" e "segunda". Os "segundas" quando não estão cantando, não se defrontam com seu parceiro. Com exceção do violeiro, todos dançam de mãos nas algibeiras; só ao finalizar o canto, quando todos dão um giro de corpo, é que as retiram, para ter maior liberdade de movimentos. Quando o "canturião" finaliza o seu canto numa carreira, ele e seu "segunda" dão um giro em torno de si mesmos, movimento elegante, no qual os pretos são ímpares para executar um trejeito harmonioso e destro. Ao finalizar tal giro, aquele que não está tocando viola bate palmas. As batidas de palmas às vezes também aparecem no começo da dança, para "afirmar" o ritmo da mudança dos pés. Uma vez firme, deixam de bater as palmas de marcação ${ }^{71}$.

Maynard Araújo também procurou sintetizar a coreografia do Cururu rural paulista através do gráfico reproduzido a seguir, na figura 12:

chico, sapo, ou serra-baile, dançado muitas vezes com tamancos, em assoalhos de madeira. Cf. ARAÚJO, Cultura popular brasileira. Op. cit., p. 68-70.

${ }^{71}$ ARAÚJO, Cururu rural. Op. cit., p. 41. 


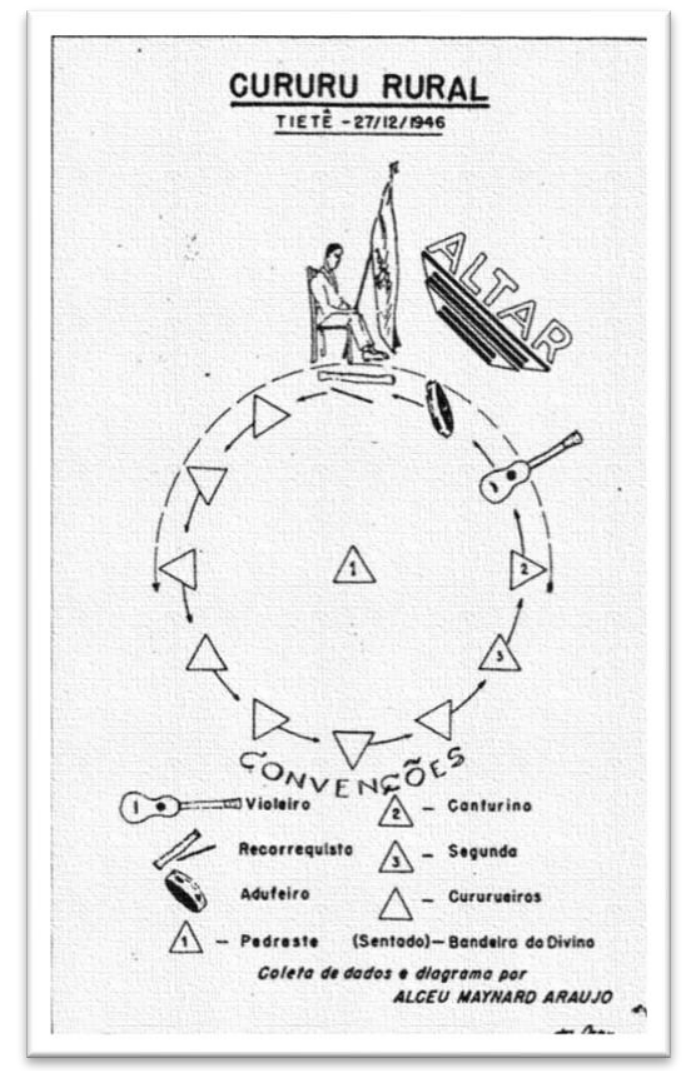

Figura 12: Coreografia do Cururu paulista Fonte: Araújo, 1949

Através de alguns dos aspectos da coreografia aqui destacados, é possível estabelecer paralelos entre o Cururu e outras danças antigas que têm o seu nome citado na documentação produzida no Brasil ao longo do século XIX. As danças de São Gonçalo e Santa Cruz são dois dos exemplos que, guardadas as diferenças regionais, possuem em suas coreografias tanto a disposição dos dançarinos em filas - na dança de Santa Cruz, filas horizontais em relação à cruz reverenciada (figura 13), e na de São Gonçalo, duas filas perpendiculares em relação ao altar, uma de homens e outra de mulheres (figura 14) - quanto o momento em que todos formam a roda ${ }^{72}$. As danças em roda do folclore brasileiro são, ademais, frequentemente associadas a práticas rituais indígenas, associação que se justifica, no caso do Cururu, pelo nome da dança e a proximidade entre colonos e nativos revelada na sua história.

\footnotetext{
${ }^{72}$ PEREIRA, Niomar de Souza. São Gonçalo nós louvamos com canto, dança e viola. Revista goiana de artes. Goiânia: IA/UFG, v. 7 n. 1, jan/dez 1986, pp. 55-69. p. 68. Ver também: Enciclopédia da música brasileira. São Paulo: Art Ed., 1977, v.1 p. 222-3. Em São Paulo, aliás, costumava-se dançar o Cururu ao final destas duas danças.
} 


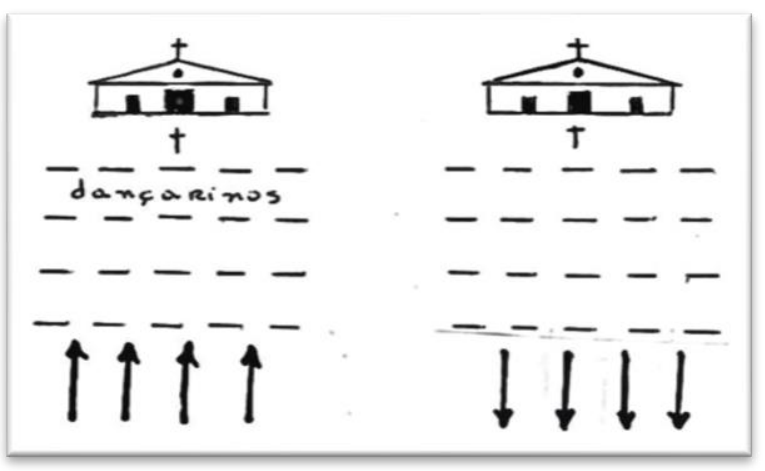

Figura 13: Movimento dos dançarinos na dança de Santa Cruz (Carapicuíba) Fonte: Escalante, 1974

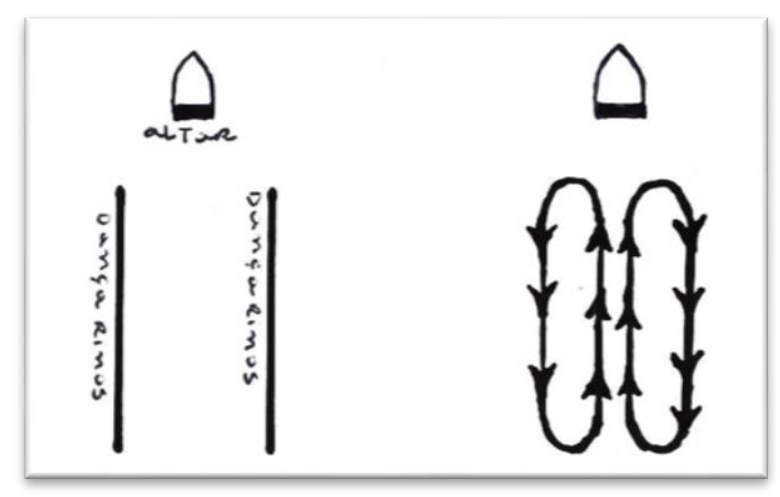

Figura 14: Movimento em fila dos dançarinos na dança de São Gonçalo Fonte: o autor.

Estando o movimento em roda presente na dança de diversas culturas antigas, vale lembrar que na Europa Medieval a mais popular de todas as manifestações do tipo foi a carola ou chorea, dança de roda citada nas crônicas da Abadia de Saint Martial de Limoges, entre os anos de 1205 e 127873. Esta e outras danças antigas, como a judenga, a mourisca e a cativa, estiveram presentes na formação das tradições portuguesas e guardam uma possível relação com as práticas que animavam a "Festa do Charolo" em Bragança, ou a "Dança do Rei David", ainda dançada em Braga e que teria sido possivelmente uma dança religiosa ${ }^{74}$.

No Brasil, autores como Couto de Magalhães e Mário de Andrade associam o Cururu ao aproveitamento de danças indígenas para as festas de São Gonçalo e Santa Cruz. Luiz Heitor Corrêa de Azevedo, por sua vez, acredita que as danças de São Gonçalo e o próprio Cururu tenham surgido a partir de outra dança cujo nome é

\footnotetext{
73 BOURCIER, Paul. História da dança no Ocidente. São Paulo: Martins Fontes, 2006, p. 47-8. Ver também: RIBAS, Tomaz. Danças populares portuguesas. Amadora, Portugal: Bertrand, 1983, p. 36.

74 CHAVES, Luís. "Danças religiosas", in Revista Guimarães. Vol LI, 1942, 3-18, p. 13.
} 
também de origem indígena: o cateretêt ${ }^{75}$. Em suas pesquisas sobre a Festa de Santa Cruz na aldeia paulista de Carapicuíba, Eduardo Escalante reconhece que foram várias as expressões musicais da Península Ibérica que se adaptaram à realidade da América Portuguesa, mesclando-se às culturas nativas, num fenômeno que resultou na pluralidade do folclore que hoje possuímos. Na maioria das vezes, as evidências deste passado se revelam na tradição renovada a cada ano das festas populares, a despeito da escassez de registros ou mesmo de referências à sua música.

Quanto lamentamos não poder contar com documentos musicais daquela época! No tempo, esses cantos confundiram-se e transmutaram-se na fusão das culturas heterogêneas que aportaram nas terras do Novo Mundo. Resta-nos a tradição latente desses homens devotos que, em louvor à cruz, revivem anualmente a herança de seus antepassados ${ }^{76}$.

\footnotetext{
75 AZEVEDO, Luiz Heitor Corrêa. Relação dos discos gravados no Estado de Goiás (junho de 1942). Rio de Janeiro: MCML, 1950, p. 28. Luiz Heitor faz esta afirmação baseando-se provavelmente na hipótese defendida por Couto de Magalhães acerca da apropriação de danças rituais nativas para culto católico trazido pelos jesuítas. Se existe uma explicação de Azevedo para a relação que ele estabelece entre estas danças, não tivemos acesso a elas.

${ }^{76}$ ESCALANTE, A festa de Santa Cruz. Op. cit., p. 23.
} 


\section{CAPÍTULO II}

\section{CATIVOS E CAMARADAS}

[...] por toda parte onde chegávamos, à noite, éramos recebidos com as toadas das violas a cujo acompanhamento se canta ou se dança.

Spix e Martius, Viagem pelo Brasil, 1823.

Em grande parte da crônica dos viajantes estrangeiros, encontramos referências à música praticada nos sertões e povoados interioranos do Brasil oitocentista. O livro Viagem pelo Brasil de Spix e Martius é um dos melhores exemplos desta lavra, apresentando em seus três volumes os resultados da Missão Artística Austro-Alemã, que percorreu, de 1817 a 1820, as regiões dos atuais estados do Rio de Janeiro, São Paulo, Minas Gerais, Bahia, Pernambuco, Piauí, Maranhão, Pará e Amazonas. Além da descrição de cenas da vida musical do Brasil colonial, como os cantos e danças com violas ouvidos nos caminhos das Minas, a publicação alemã trazia um anexo com 23 músicas transcritas em partitura, sendo 14 melodias indígenas, um lundu instrumental e mais oito números intitulados Brasilianishe Volkslieder (Cantigas Populares Brasileiras) ${ }^{1}$. 0 propósito de integrar em uma única abordagem os seus trabalhos de naturalistas com o levantamento de expressões de cultura locais indicava, segundo Merhy, a sintonia dos autores com o espírito da época, buscando explicar o ambiente brasileiro pela ótica iluminista ${ }^{2}$. Assim, as transcrições musicais de Spix e Martius contribuíam para "uma visão do novo mundo a mais completa possível, da qual as práticas culturais faziam parte" ${ }^{3}$. Outro estudo do período cujo escopo não se limitou apenas ao campo das ciências naturais foi o

\footnotetext{
${ }^{1}$ SPIX, Johann Baptist von; MARTIUS, Carl. Friedrich Philipp von. Viagem pelo Brasil: 1817-1820. Rio de Janeiro: Imprensa Nacional, 1938, 2a ed., v. 1 p. 191 e 275.

${ }_{2}^{2}$ MERHY, Silvio Augusto. As transcrições das canções populares em Viagem pelo Brasil de Spix e Martius. Revista brasileira de música. RJ: UFRJ, 2010, v. 23/2, pp. 173-206, p. 174.

${ }^{3}$ Ibidem, p. 188.
} 
relato do francês Hercules Florence, o mais detalhado acerca da expedição científica chefiada pelo Barão de Langsdorff. Em sua Viagem fluvial do Tietê ao Amazonas, realizada entre os anos 1825 e 1829, Florence descreveu batuques praticados por camaradas em Cubatão, a bandeira do Divino em Diamantino e uma banda de música formada por negros cativos da Fazenda Jacobina, ambas na província de Mato Grosso, além da inseparável viola dos tapuios nos arredores de Santarém, às margens do rio Amazonas ${ }^{4}$. A iconografia de artistas como Debret, Chamberlain, Rugendas, Seyffer, Bittheuser, Ender e do próprio Florence, revelou-se igualmente indispensável para o conhecimento do tema, por ser constante a representação de cenas do quotidiano da sociedade brasileira daquele período em que se faziam presentes a música e a dança 5 . Destacam-se neste conjunto as diversas gravuras de negros musicistas feitas por Debret (figura1), assim como as cenas musicais de colonos nas pinturas a óleo de Rugengas (figura 2).

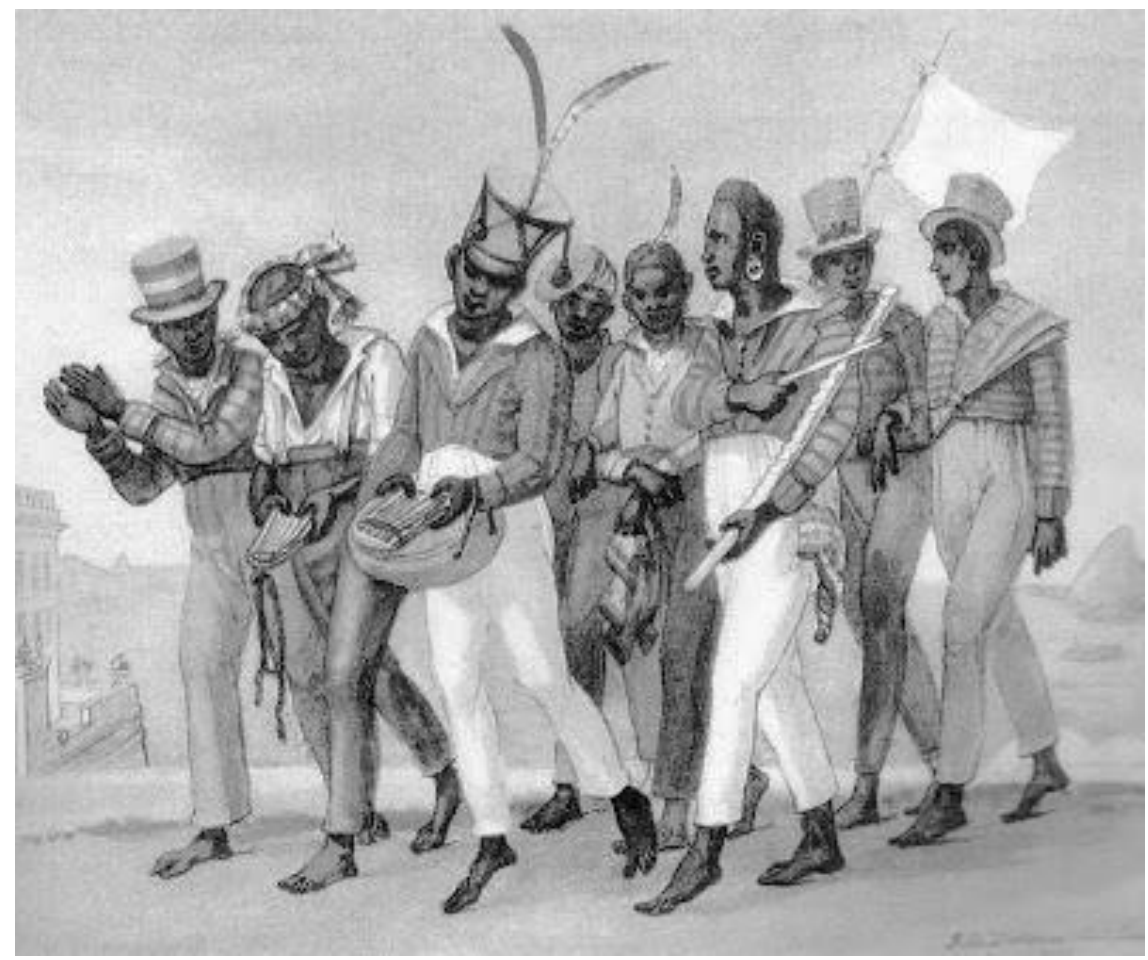

Figura 1: Passeio de domingo à tarde Fonte: Debret, 2008

\footnotetext{
${ }^{4}$ FLORENCE, Hercules. Viagem fluvial do Tietê ao Amazonas de 1825 a 1829. Brasília: Senado Federal, 2007, passim.

${ }^{5}$ PEQUENO, Mercedes Reis. Três Séculos de Iconografia da música no Brasil. Catálogo de exposição. Rio de Janeiro: Biblioteca Nacional, 1974.
} 


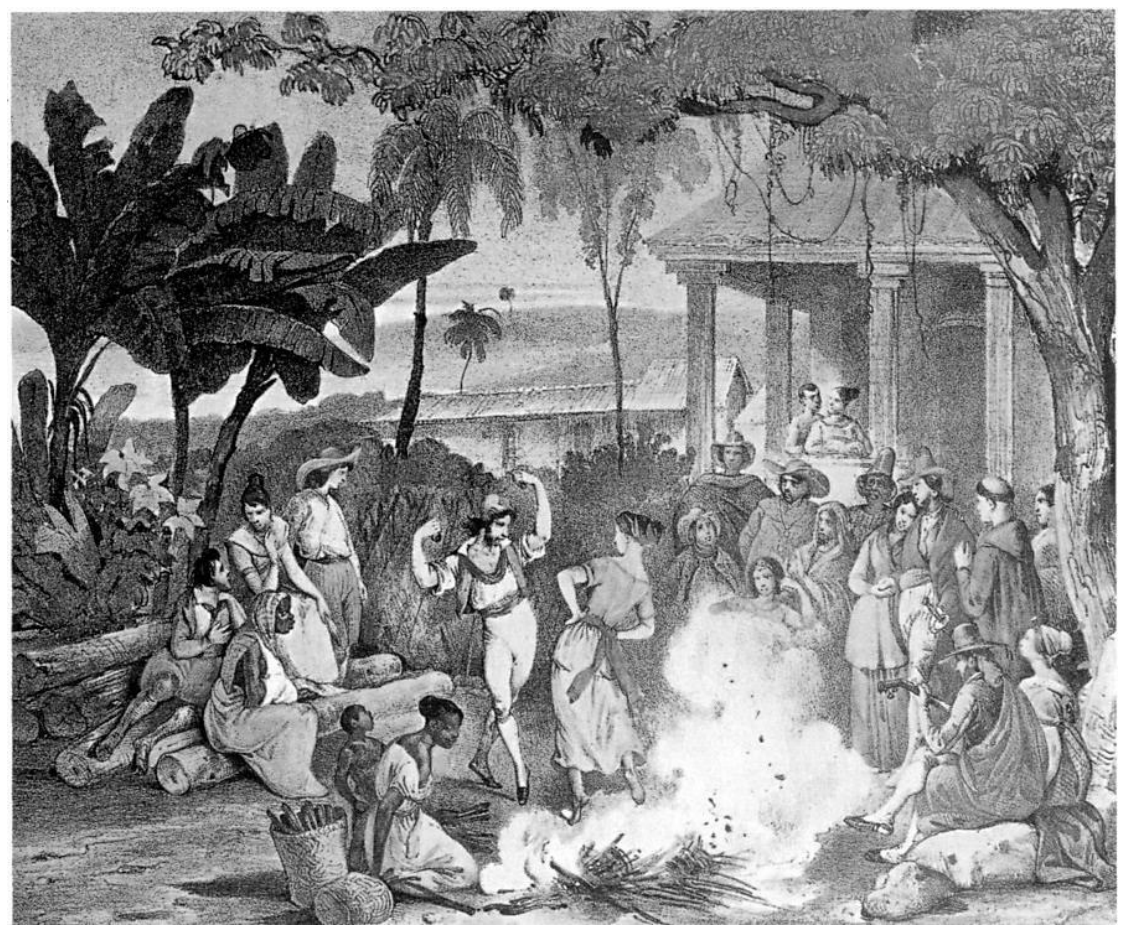

Figura 2: Rugengas, Lundu

Fonte: Biblioteca Nacional, 2006

No caso específico do emprego da palavra cururu designando canto e dança, a primeira referência em livro é também a de um cronista estrangeiro. Trata-se do relato de 1869 do português Joaquim Ferreira Moutinho, um dos primeiros a descrever o seu cultivo entre as "classes baixas e a gente do campo" ${ }^{6}$. Karl von den Steinen foi outro estrangeiro que observou a mesma dança na periferia da cidade de Cuiabá em sua viagem no ano de 1887, também empregando o referido termo em sua publicação de 1894. Foi também um dos pioneiros na descrição dos instrumentos musicais usados, bem como de algumas das peculiaridades do cultivo da dança e do canto ali praticados ${ }^{7}$. Simultaneamente, encontramos na literatura de Alfredo d'Escragnolle Taunay outra antiga referência. Tendo atuado na guerra do Paraguai como engenheiro militar, de 1864 a 1870, Taunay conheceu em detalhes o ambiente rural da parte sudeste da então província de Mato Grosso (atualmente Mato Grosso do Sul) e extraiu dos costumes e valores daquela região a inspiração para sua mais famosa obra de ficção, o romance Inocência, publicado em 1872. Nele, foram descritos diferentes tipos de violas nas mãos dos camaradas que ali buscavam trabalho, o canto

\footnotetext{
${ }^{6}$ MOUTINHO, Joaquim Ferreira. Notícia sobre a província de Mato Grosso seguida d'um roteiro da viagem da sua capital a S. Paulo. São Paulo: Typografia de Henrique Schroeder, 1869, p. 18.

${ }^{7}$ STEINEN, Karl von den. Entre os aborígenes do Brasil central. São Paulo: Dep. De Cultura, 1940, p. 711.
} 
das mulheres consideradas de má reputação, além da música que animava as festas mais importantes daquelas paragens. Mais um autor deste período a mencionar pioneiramente o termo cururu foi o general Couto de Magalhães, que destacou em conferência proferida no ano de 1897 a referida prática entre os índios aculturados da região de São Paulo e apontou sua origem no trabalho de catequese promovido pelos padres jesuítas. Couto de Magalhães identificou tal manifestação não apenas no território brasileiro como defendeu na época a existência da mesma prática nos vizinhos Paraguai, Argentina e Bolívia ${ }^{8}$. Também merece destaque o registro da dança feito em 1901 por Max Schmidt, testemunhando o seu cultivo entre "pessoas de todas as gradações de cor", na cidade mato-grossense de Rosário Oeste, ainda hoje uma das regiões caracterizadas pela forte herança da escravidão de origem africana. Por ocasião das festas do mês de dezembro, Schmidt registrou nesta localidade a prática do Cururu, do Siriri e da dança do Congo, sendo este também um dos mais importantes relatos antigos sobre o tema ${ }^{9}$. Por fim, cabe mencionar o primeiro registro sonoro de Cururus mato-grossenses, feito por Edgard Roquette-Pinto em 1912. Como integrante da Missão Rondon, Roquette-Pinto reuniu um vasto acervo etnográfico para o Museu Nacional do Rio de Janeiro, incluindo a gravação de três cantos sertanejos cuiabanos ${ }^{10}$.

O que os exemplos de Moutinho, Steinen, Taunay, Magalhães, Schmidt e Roquette-Pinto guardam em comum, além das referências feitas aos gêneros de canto e dança que aqui estudamos, é o fato dos sujeitos destas práticas integrarem em sua maioria uma parcela da população conhecida durante o Brasil Colônia e o Império pelo nome de camaradas. Segundo Divino Marcos de Sena, esse grupo complexo de homens que não eram senhores nem escravos encontrou na condição de trabalhadores livres e pobres os meios de garantir sua subsistência, atuando nos

\footnotetext{
${ }^{8} \mathrm{~A}$ afirmação do político e folclorista mineiro relacionando o uso do mesmo tipo de violas à música introduzida pelos jesuítas castelhanos nestes países é por nós comentada no capítulo III desta tese. Cf. COUTO DE MAGALHÃES, General. Anchieta e as raças e as línguas indígenas. $7^{\mathrm{a}}$ Conferência para o tricentenário de Anchieta. São Paulo: Typografia C. Gerke e Cia, 1897, p. 30.

${ }^{9}$ SCHMIDT, Max. Estudos de etnologia brasileira: peripécias de uma viagem entre 1900 e 1901. São Paulo: Cia. Ed. Nacional, 1942, p. 13-14. Cabe ressaltar que, anteriores aos registros acima citados, há também os relatos de práticas musicais na região, em cujo texto seus autores não empregam a palavra Cururu. Os detalhes apresentados nestes registros nos levaram, todavia, a relacionar com segurança tais práticas à mesma categoria estudada. São eles os estudos de Castelnau (1847), Koslowsky (1894) e do próprio Steinen (1884). Para mais detalhes, ver cap. III p. 106-19.

${ }^{10}$ ROQUETTE-PINTO, Edgard. Rondônia. Rio de Janeiro: Imprensa Nacional, 1919, p. 325.
} 
garimpos e fazendas, assim como nos transportes fluvial e terrestre. Tanto o modo como eram contratados quanto a diversidade de funções exercidas fizeram com que muitos camaradas não fixassem moradia por muito tempo nas localidades onde se oferecia trabalho, daí resultando uma maior mobilidade e um maior intercâmbio de pessoas na região, sempre lembrada por sua geografia distante dos centros da administração e negócios do Império ${ }^{11}$.

0 que se conhece hoje a respeito da presença desta parcela heterogênea da sociedade, em Mato Grosso dos séculos XVIII e XIX, é devido em grande parte aos relatos destes viajantes e aos documentos dos processos criminais do mesmo período, envolvendo peões de fazendas e membros de comunidades ribeirinhas nos arredores das principais cidades da província. Muitos deles eram índios que se encontravam na condição de trabalhadores pobres e sem acesso à terra que, pela considerável perda de elementos da sua cultura tradicional, eram considerados apenas "remanescentes", sendo por esta razão alvos de uma depreciação ainda maior. O controle rígido da vida social destes homens era uma das preocupações que tinham as autoridades responsáveis pela manutenção da ordem estabelecida, uma vez que a forma esporádica com que eram remunerados e a posição marginal que ocupavam na sociedade imprimiam nestes mesmos indivíduos a pecha de desocupados ${ }^{12}$. Deste modo, as rodas de Cururu e os Batuques, que constituíam o principal espaço de sociabilidade das camadas baixas acabaram se transformando em um dos principais alvos da repressão policial nas principais cidades da Província, por serem consideradas contrárias aos modos civilizados e frequentemente associadas a bebedeiras, brigas e assassinatos.

Neste capítulo, analiso a prática do Cururu entre os camaradas e os negros cativos na sociedade mato-grossense do século XIX, tendo como principais fontes as crônicas dos visitantes estrangeiros, os códigos de posturas editados pelas

\footnotetext{
${ }^{11}$ SENA, Divino Marcos de. Camaradas: livres e pobres em Mato Grosso (1808-1850). Dissertação de mestrado em história. Dourados, MS: UFGD, 2010, p. 62-3.

${ }^{12}$ VOLPATO, Luiza Rios Ricci. Cativos do sertão: vida cotidiana e escravidão em 1850/1888. Cuiabá: Marco Zero, 1993, p. 205.
} 
autoridades governamentais e os registros de ocorrências criminais envolvendo indivíduos pertencentes aos segmentos subalternos daquelas comunidades ${ }^{13}$.

Inicio com um retrato da vida musical da província neste período, dando conta não apenas do cultivo da dança nos arredores de Cuiabá e na área rural do sul de Mato Grosso, mas também de expressões de cultura dos demais segmentos daquela sociedade, como no caso dos batuques dos negros e das serenatas, bailes e festas de santos em que tomavam parte as chamadas "boas famílias". Também trato de alguns aspectos do povoamento da região, cujos primórdios estão intimamente ligados à infiltração das bandeiras paulistas, inicialmente para a captura de índios para o trabalho escravo e posteriormente para a exploração das minas de ouro e diamante descobertas no final do século XVII. A promessa do Eldorado atraiu mineiros e colonos de diversas localidades, estabelecendo nas terras de Mato Grosso uma rede de atividades que ligavam a mineração não só ao transporte fluvial entre São Paulo e Cuiabá, mas também ao comércio nos povoados e à produção das fazendas, possibilitando a reprodução dos modos de vida do mundo rural do centro-sul gestados desde os primeiros tempos do Brasil Colônia. Juntamente com a cultura do colono trazida inicialmente pelo bandeirante paulista, busco, neste processo, entender a contribuição do escravo de origem africana, submetido ao árduo trabalho das minas de ouro e diamante da região. Além de responsáveis por firmar tradições como a dança do congo, que hoje sobrevive em cidades mato-grossenses como Nossa Senhora do Livramento e Vila Bela da Santíssima Trindade, esses negros e seus descendentes logo se apropriaram de manifestações como o Cururu, mesclando muitos dos seus costumes com os do colono ${ }^{14}$. Através da análise de documentos como as Posturas Municipais e as ocorrências policiais deste período, procuro também aferir a tênue distância entre o lugar social do escravo e do trabalhador livre e pobre da região, motivada pela distância física dos centros da economia nacional e a carência de recursos monetários necessários na compra desta força de trabalho ${ }^{15}$. Por fim, reflito sobre outra designação genérica para o habitante pobre da região, a de

\footnotetext{
${ }^{13}$ Estes processos referentes ao Cururu e seus praticantes, na Cuiabá da segunda metade do século XIX, encontram-se no Arquivo Público de Mato Grosso e foram também estudados pelos pesquisadores Luiza Rios Ricci Volpato (1993), Verone Cristina Silva (2001) e Cleber Alves Pereira Júnior (2011).

${ }^{14}$ SCHMIDT, Op. cit., p. 13-17.

${ }^{15}$ VOLPATO, Op. cit., p. 15.
} 
ribeirinho. Este tipo, tradicionalmente representado pelo habitante das proximidades dos rios, cujo meio de subsistência circunscreve-se não apenas à coleta de peixes, será também identificado por outras atividades desempenhadas no campo e no entorno das cidades, com sua cultura, porém, fortemente vinculada ao mundo rural e à herança indígena.

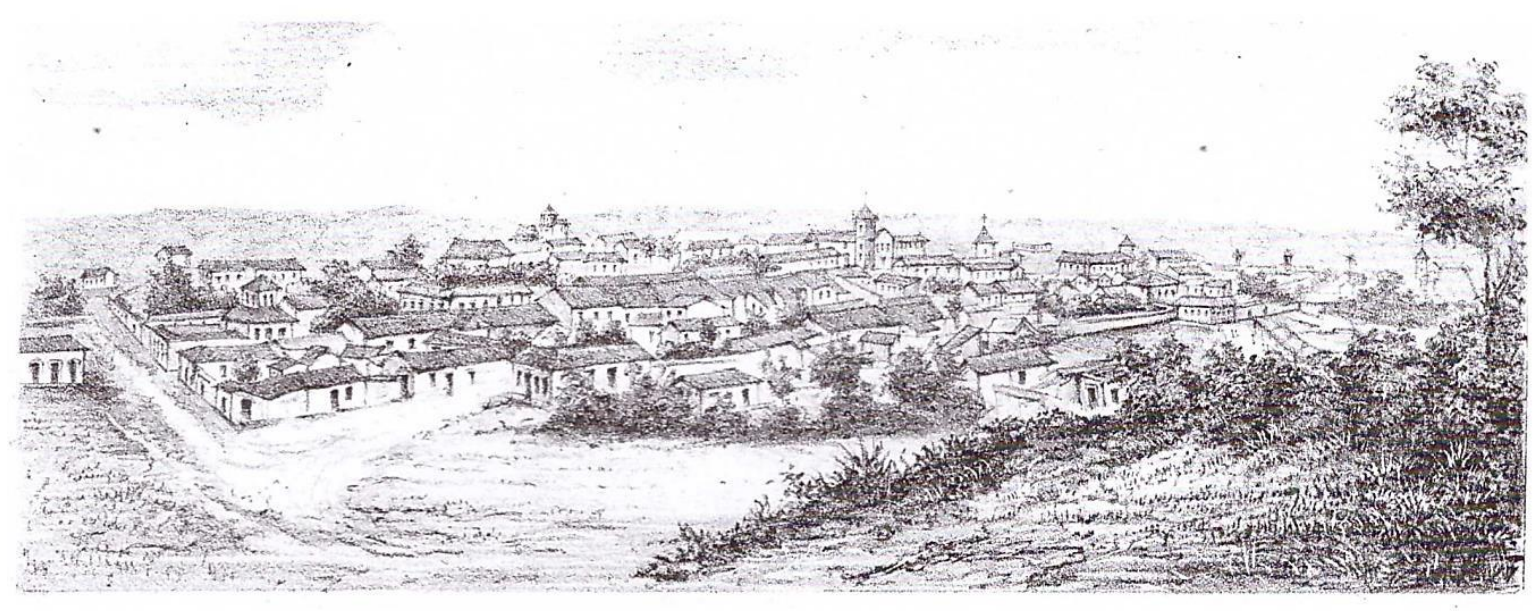

Figura 3: Florence, vista de Cuiabá em 1827

Fonte: Freitas, 2011

\section{CRONISTAS EM MATO GROSSO}

Tratamos inicialmente da contribuição dos viajantes estrangeiros para o conhecimento da natureza, dos povos nativos e dos colonos em diversas regiões do território brasileiro. Em vários momentos, estes mesmos viajantes tiveram um olhar atento para o entrecruzamento das culturas destes povos, relatando a vida dos núcleos e dos arredores das cidades, bem como a dos sertões pouco habitados. Dentre aqueles que observaram pioneiramente a sociedade mato-grossense através de seus personagens, costumes e conflitos, destaca-se o português Joaquim Ferreira Moutinho. Tendo sido mais que um viajante, já que viveu na região de 1850 a 1868, Moutinho não só procurou traçar um panorama das possibilidades econômicas do lugar como também esteve sensível aos costumes e à cultura dos seus habitantes, incluindo os camaradas. Casou-se, segundo Siqueira, com uma cuiabana, teve filhos e viveu alguns dos episódios mais dramáticos da história da província. Presenciou os efeitos trágicos da invasão das tropas paraguaias, iniciada em dezembro de 1864, como no caso das agruras da epidemia de varíola trazida pela guerra, que vitimou um 
de seus filhos ${ }^{16}$. Também testemunhou a enorme enchente de 1865, do rio Cuiabá, e viveu o clima de animosidade em relação aos estrangeiros, ainda derivado da revolta popular de 1834 que ficou conhecida pelo nome de Rusga ${ }^{17}$. Por ter provavelmente se estabelecido como comerciante neste período, boa parte da visão depreciativa de Moutinho acerca das condições de vida das pessoas e da política local advinha de sua expectativa em relação ao potencial econômico da região. Daí a razão para a constante crítica em sua crônica, por ser a região uma das mais bem dotadas de recursos naturais de todo o país, estando, porém, “tão pouco aquinhoada [...] pelo Governo na distribuição dos seus favores, que tudo ali é difícil, e tudo existe ainda no seu estado embrionário" 18.

Além disso, identificamos em seu relato uma especial atenção prestada à vida musical da província. A predileção pela música em Cuiabá, segundo o cronista, era "dominante entre homens e senhoras" e parecem ter as serenatas ao ar livre o encantado em particular, ao ponto de lamentar o declínio deste cultivo na capital.

Nas noites de luar que são lindíssimas naquelas paragens, e como nunca as apreciamos em outro qualquer ponto da America do Sul, costumavam os músicos de profissão ou os amadores a fazer poéticas serenatas, que ainda mais encantadoras tornavam essas noites cheias de magia e doçura. Por último essas serenatas foram se fazendo mais raras, e hoje quase que têm desaparecido, sem que possamos atinar com a causa verdadeira desse indeferentismo que vai lavrando entre as diversas classes da sociedade. E que as obriga a fugir aos prazeres de que antes eram apaixonadas ${ }^{19}$.

Também os bailes eram divertimentos que vinham se tornando raros, com as pessoas cada vez mais recolhidas em suas casas, mas sendo neles ainda possível notar o entusiasmo dos seus frequentadores, "em razão de serem considerados verdadeiras novidades" 20. É provável que essa diminuição no número de reuniões dançantes e serenatas, bem como a apatia das pessoas em manter vivo um costume que elas tanto

\footnotetext{
${ }^{16}$ SIQUEIRA. Elizabeth Madureira. História de Mato grosso: da ancestralidade aos dias atuais. Cuiabá: Entrelinhas, 2002, p. 140.

${ }^{17}$ MOUTINHO, Op. cit., p. 8-11.

${ }^{18}$ Ibidem, p. 7

19 Ibidem, p. 18.

${ }^{20}$ Ibidem, p. 15.
} 
prezavam, tenha se dado em virtude das tragédias que abateram Mato Grosso naquele tempo. Moutinho assinala que, somado aos saques das propriedades do sul da província e à violência a que foram submetidos seus habitantes pela invasão das tropas paraguaias, "o flagelo das bexigas", como foi chamado o surto de varíola de 1867, reduziu para menos da metade a população da capital e fez com que o povo perdesse a disposição física e moral necessária para a superação de tantas adversidades. Para o autor, o quadro de crise era ainda agravado pelo descaso do governo central no envio de recursos e pela nomeação desastrosa de seus representantes, como no caso da escolha do então presidente da província, o general Couto de Magalhães ${ }^{21}$.

Em relação aos instrumentos musicais normalmente presentes na vida doméstica daqueles moradores, Moutinho nos fala da preferência dos cuiabanos pelo piano, a flauta, o violino e o violão, com seu estudo "cultivado com feliz resultado". Não se atém a um levantamento preciso, mas menciona a existência de dezesseis pianos no mobiliário das casas de família e nos locais de convívio social, tendo esta referência o intuito de ressaltar a presença variada da música no quotidiano das famílias ${ }^{22}$.

Mais repletas de detalhes são, porém, as descrições dos folguedos praticados pelos habitantes pobres da cidade. Mesmo marcadas pelo estranhamento e pela reprovação ao gosto de seus praticantes, como era típico dos representantes da elite local, essas descrições também revelam o quanto o entusiasmo daqueles personagens no cultivo de suas danças impressionara o cronista português naquele momento. Ali temos provavelmente o mais antigo relato produzido em Mato Grosso em que são empregadas as palavras cururu e cocho, designando respectivamente a dança com canto que aqui estudamos e o seu principal instrumento musical acompanhante. Outro aspecto a ser considerado em sua observação, é que Moutinho ajuíza negativamente que só mesmo as danças dos índios selvagens eram para ele carregadas de mais exotismo que o Cururu dos cuiabanos.

\footnotetext{
${ }^{21}$ Ibidem, p. 9.

22 Ibidem, p. 18.
} 
Quanto ao gosto pela música entre as classes baixas e a gente do campo, resume-se ele no uso de um instrumento a que dão o nome de "cocho", que não é mais do que uma viola grosseira, do adufo e do tambor que é feito de um pedaço de pau oco, coberto com couro de boi afinado ao calor do fogo.

Ao som desses instrumentos dançam o "cururu", o mais insípido e extravagante divertimento a que temos assistido, depois da dança dos bugres. Formam uma roda composta de homens, um dos quais toca o afamado cocho, e volteando burlescamente, cantam à porfia numa toada assaz desagradável versos improvisados ${ }^{23}$.

Ainda sobre as afinidades apontadas entre as representações do Cururu em Mato Grosso e a sua presença na cultura dos índios, o cronista português prossegue descrevendo alguns detalhes destas práticas que também coincidem com o que relacionamos no segundo capítulo desta tese. Em 1900 Schmidt relata, por exemplo, os humores exaltados e as manifestações violentas dos praticantes do Cururu na etnia Guató motivados pelo consumo intenso da aguardente de cana e da chicha, a bebida da tradição antiga daqueles povos. 0 mesmo aspecto é ressaltado por Koslowsky seis anos antes, ao visitar estes índios na região do Amolar, sendo possível identificar nos dois casos a mesma herança nativa das longas e inebriantes festas regadas a cauim, como as que foram registradas pelo frei Cardim nos primórdios da Colonização ${ }^{24}$. Outros aspectos do Cururu, como a disposição dos dançarinos em roda, os volteios dos violeiros e cantadores, além do improviso nos versos cantados, são igualmente lembrados nas crônicas destes autores. Vejamos, então, o que diz o cronista português:

Este folguedo é sempre acompanhado da apreciada - cachaça - que não dispensam, e de uma outra bebida conhecida sob o nome de aluá - feita de arroz ou de milho em fermentação.

É admirável a força dos pulmões desses cantores "sui generis" que, começando a cantar ao descambar do dia, veem o despontar da aurora sempre cantando, e prosseguem até a noite seguinte sem descanso de um só momento. Finalizam o folguedo sempre no estado da mais completa embriaguez.

Dois ou três dias depois estão dispostos a tripudiar de novo, e assim levam a vida folgada e sem cuidados, entregues a esses prazeres brutais que julgam superiores a todas as distrações da alta sociedade.

\footnotetext{
${ }^{23}$ Ibidem, p. 18.

${ }^{24}$ KOSLOWSKY, Julio. Tres semanas entre los indios Guatós: excursión efectuada en 1894. Revista del Museo de La Plata. Tomo VI, 1895, p. 231.
} 
Algumas vezes as mulheres fazem parte do "cururu", mas cedem logo aos efeitos da cachaça e ficam prostradas mesmo no lugar da festa, até que se dissipe a bebedeira ${ }^{25}$.

Também com Moutinho é possível identificar o caráter tanto religioso quanto profano da dança, uma vez que o autor observa que seus brincantes costumam sempre folgar em homenagem a algum santo, obedecendo ao calendário das festividades católicas $^{26}$. Em suas descrições, eles participam coletivamente do preparo das festas e dos rituais de fé que têm no Cururu um dos pontos altos das celebrações e divertem-se, ao mesmo tempo, retratando os prazeres mundanos da vida e o pitoresco das relações entre homens e mulheres ${ }^{27}$.

Karl von den Steinen foi outro estrangeiro que retratou a vida musical da elite e das classes baixas da sociedade mato-grossense do século XIX. No seu livro O Brasil Central, que documenta a expedição ao rio Xingu de 1884, o naturalista alemão narra a sua estada em Cuiabá citando inicialmente as bandas militares que se revezavam aos sábados em apresentações nos jardins da residência oficial da presidência da Província28. Estas mesmas bandas também atendiam à população local nas celebrações religiosas, conforme pôde atestar participando dos vários festejos ligados à Semana Santa daquele ano:

Reunimo-nos à noite na igreja do Rosário, onde a concorrência era enorme. Do lado de fora achavam-se os archoteiros, de capas verdes, em volta da cruz [...]. Duas bandas militares. Uma menina que representava Santa Verônica achava-se de pé, sobre um pedestal, a desdobrar o véu e elevando a voz estridente numa lamentação que repetia cada vez que paravam [...]. Negros, grandes e pequenos, cantaram, olhando para a música, uma melodia uniforme e com um instrumento especial arrancavam sons esquisitos como estalidos. [No "sábado de Aleluia"], quando as lojas já abriam as suas portas, as igrejas ainda eram visitadas e à noite toda a cidade dançava ${ }^{29}$.

\footnotetext{
${ }^{25}$ MOUTINHO, Op. cit., p. 18-9.

26 Ibidem, p. 20

27 Ibidem, p. 21

${ }^{28}$ STEINEN, Karl von den. O Brasil central: expedição em 1884 para a exploração do rio Xingu. São Paulo: Cia Ed. Nacional, 1942, p. 79.

${ }^{29}$ Ibidem, p. 90-2.
} 
Eventualmente, estas bandas militares também atuavam como orquestras de teatro, em participação nas representações dramáticas encenadas na sede da sociedade cultural Amor à Arte, além de se fazerem presentes nas agremiações voltadas para o lazer cultural da elite local, que se dedicavam à promoção de chás dançantes e saraus literomusicais ${ }^{30}$. A programação do clube Terpsícore, promovida pelos dirigentes do partido Liberal, constava, por exemplo, de discursos, palestras e debates, seguidos de apresentações de canto e piano. Ao final, dançava-se ao som das bandas de sopros ${ }^{31}$. Um pouco mais animadas eram, ainda segundo Steinen, as reuniões da agremiação concorrente que abrigava os membros do partido conservador, o Recreio Cuiabano:

Num baile do Recreio realizado na residência do chefe do partido, a sociedade apresentou-se bastante misturada, predominando indivíduos pardo-escuros. Isso ainda mais chamava a atenção desde que a esposa do Presidente e ainda algumas "filhas de outras províncias" também estavam presentes. Começaram pela terceira parte do programa. Dançava-se animadamente em três grandes compartimentos ${ }^{32}$.

Steinen também observou a música praticada na periferia da Capital, experiência esta que foi registrada no apêndice do seu segundo livro sobre Mato Grosso, Entre os aborígenes do Brasil Central, publicado em 1894. Nesta obra, o naturalista fala dos participantes do Cururu, dos instrumentos utilizados, da coreografia e dos rituais de devoção que normalmente acompanhavam o folguedo. Por se tratar de notas de apêndice, o estilo adotado é mais próximo daquele encontrado nos verbetes dos dicionários de folclore, não apresentando assim o mesmo frescor da sua crônica anterior. E mesmo revelando algumas possíveis imprecisões, os detalhes apresentados coincidem em boa parte com as descrições de seus contemporâneos, dando conta da curiosidade e do estranhamento despertados nos visitantes que àquela época tinham a chance de conhecer a cultura dos arredores da cidade. Um aspecto a ser destacado no relato é o pioneirismo na identificação da expressão de canto e dança que estudamos, uma vez que o termo cururu é

\footnotetext{
${ }^{30}$ Ibidem p. 79.

${ }^{31}$ Ibidem p. 81-2.

32 Ibidem p. 83.
} 
anteriormente empregado, segundo o que se sabe até o momento presente, apenas na crônica de Moutinho. Trata-se, portanto, de uma das descrições mais antigas do Cururu, pela qual o autor não só menciona o nome da dança como também busca definir suas peculiaridades. São estas as suas impressões:

O cururu é a dança preferida do Mato Grosso, da qual só participam os homens. Instrumentos de música: Koscho, violino com poucas cordas de tripa que os próprios moradores fabricam de madeira de salgueiro; Krakaschá, um pedaço de bambu ou uma cuia comprida com entalhos, o qual se toca outro pedaço de bambu "krakascha..."; Adufe, um tamborim com velhas moedas de cobre em vez de guizos; Viola, o violino com cordas de arame; às vezes a Marimba dos negros. 0 início da festa é um jogo em que todas as pessoas da festa tomam parte. Dança-se e canta-se em roda do santo, e quem passa diante dele, faz uma genuflexão. Em seguida canta-se em honra do rei e da rainha, os dois entram no círculo munidos da garrafa de cachaça, oferecendo um trago a cada um e juntando depois ao círculo, que passa a cantar para outro personagem, o qual, por sua vez, oferece cachaça, e assim por diante. Há versos em quantidade, sempre em quadras, e sobre os mais variados assuntos; no cururu os cantos de devoção são seguidos pelos de amor, de zombaria e outros inventados conforme as inspirações do momento; as quadras adaptam-se ao humor da festa e as conhecidas são substituídas, dentre em pouco, pelas improvisadas ${ }^{33}$.

Para Elisabeth Travassos, as descrições de Steinen, embora importantes por fazer referência aos nomes da viola-de-cocho e do Cururu nas festas religiosas de Cuiabá, suscitam algumas dúvidas. A primeira delas diz respeito à presença naquele contexto da marimba ou marimbau, instrumento transplantado das culturas bantu da África subsaariana e que hoje apenas subsiste isoladamente nas congadas do litoral norte de São Paulo (detalhe na figura 5). A marimba de negros, hoje praticamente desaparecida no território brasileiro, foi bastante popular até o séc. XIX, sendo provável que ela estivesse, para Travassos, presente na cultura dos camaradas que viviam nos arredores da Cuiabá de 1884, mas não especificamente na prática do Cururu. Outra questão levantada é a do uso das violas. Tanto aquela por ele chamada de Koscho (ao que tudo indica, a viola-de-cocho, tal como a conhecemos hoje em dia e que à época era também o instrumento musical mais importante do Cururu) quanto a

\footnotetext{
${ }^{33}$ STEINEN, Entre os aborígenes do Brasil central. Op. cit., p. 711.
} 
conhecida viola de arame (cordofone de ordens duplas de corda, que passou a ser comumente chamado no Brasil de viola caipira) são descritas como diferentes tipos de violino (geige, no alemão) de cordas dedilhadas. Travassos não só duvida de um instrumento de nome koscho, cujas cordas deveriam ser friccionadas por um arco, como também considera improvável a presença da viola de arame naquele contexto. Para a antropóloga, as afirmações que relacionam todos estes instrumentos ao cultivo do Cururu daquela época em Mato Grosso podem sugerir que o autor alemão acabara por misturar àquela representação outras descrições de danças populares também por ele observadas. 0 que se deve levar em conta, no entanto, é que a viola de arame convivia com outros tipos rústicos de violas nas práticas do Cururu paulista observadas, por exemplo, na década de 1940 por Maynard de Araújo ${ }^{34}$. Além disso, é preciso notar que o termo geige é também usado no alemão para designar genericamente mais de um tipo de instrumento de cordas, assim como acontece com o uso da palavra viola na língua portuguesa.

Juntamente com o pioneirismo dos relatos publicados em 1869 por Joaquim Ferreira Moutinho, as descrições de Steinen ressaltam em mais de um momento a proximidade da prática do Cururu com algumas representações comumente associadas às culturas de origem africana, não somente ao mencionar a marimba dos negros, mas também descrevendo um instrumento de percussão de nome tambaque, que era confeccionado a partir de "um tronco de árvore escavado e coberto com um pedaço de couro". Este termo foi igualmente usado por Steinen para designar a dança associada a ele, observada pelo autor naquela mesma ocasião ${ }^{35}$. Segundo a Enciclopédia da Música Brasileira, além de uma variação do termo atabaque, designando genericamente os tambores africanos de formato alongado com couro em uma só boca, o tambaque era também o nome de um batuque feito pelos negros durante as festas de Nossa Senhora do Rosário. Observado na província de São Paulo, o tambaque era precedido de um cortejo com rei e rainha, que ao final convidavam os

\footnotetext{
${ }^{34}$ ARAÚJO, Alceu Maynard. Cururu rural. In: Semana Nacional de Folclore. Rio de Janeiro: IBECC/CNF, 1949, v. 2. p. 36 .

${ }^{35}$ STEINEN, Entre os aborígenes do Brasil central. Op. cit., p. 711.
} 
participantes para um banquete ${ }^{36}$. Ainda no mesmo parágrafo, Steinen menciona o cultivo de outras danças, além do Cururu e os dois gêneros de origem africana. Fala do gosto por um folguedo que ele classifica como "danças de animais", descrevendoas como danças exclusivas de mulheres, dançadas nas festas de santos, que ora representam bichos como o jacaré, ora abelhas e pirilampos, ora aves como o peru. São também descritas como danças circulares que empregam bastões ou varetas nos passos em que os dançantes alternam suas posições e que, de tão inofensivas, não chegam a "magoar o santo" 37. Embora o alemão não as identifique como tal, pertencem, ao que parece, ao um conjunto de expressões caracterizado pela fusão de elementos da cultura ibérica e da aborígene ${ }^{38}$.

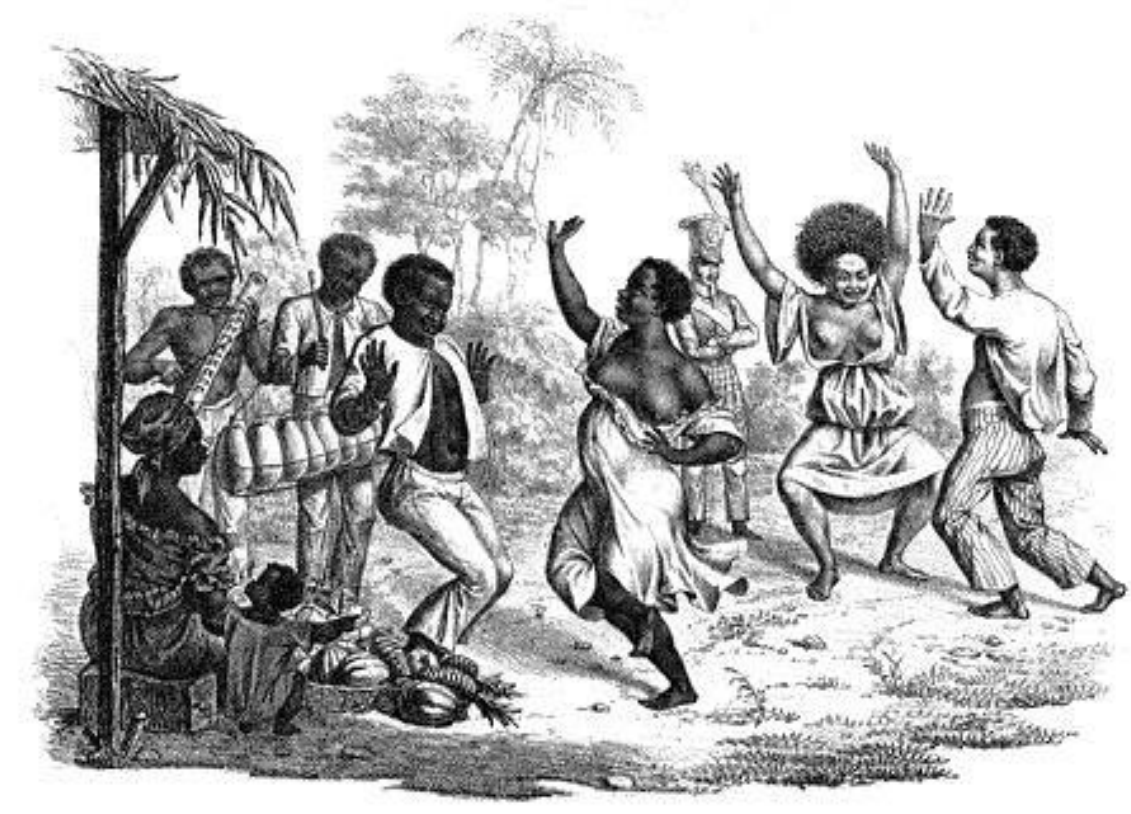

Figura 4: Batuque (instrumentos: marimba e ganzá, à esq.) Fonte: Spix e Martius, 1824

\footnotetext{
${ }^{36}$ Enciclopédia da Música Brasileira: erudita, folclórica e popular. São Paulo: Art Editora, 1977, v.1 p. 740. Ver na p. 89 deste capítulo referência à mesma dança, com sua prática proibida pelas Posturas Policiais da Câmara Municipal de Cuiabá, de 04 de janeiro de 1831. Acervo: APMT, PM 02, Caixa 1.

${ }^{37}$ STEINEN, Entre os aborígenes do Brasil central. Op. cit., p. 712.

${ }^{38}$ Herbert Baldus relaciona algumas danças de roda tribais, em especial as danças do sapo dos índios Guajajara do Maranhão, cujos traços são identificáveis em algumas expressões folclóricas estudadas no norte de Goiás. Cf. CÂNDIDO, Antônio. Possíveis raízes indígenas de uma dança popular. 1965, p. 389. Maynard Araújo também menciona os cordões de bichos, dançados no Estado do Pará, cuja influência indígena se faz sentir no uso de bastões enfeitados de penas coloridas. Cf. ARAÚJO, Alceu Maynard. Cultura popular brasileira. São Paulo: Melhoramentos, 1973, p. 61.
} 
Embora inteiramente distintas das rodas de Cururu e dos batuques praticados pelos homens e mulheres pobres dos arredores de Cuiabá, algumas das celebrações em que tomavam parte a nata da sociedade cuiabana também eram frequentadas por membros de variadas etnias, revelando nos principais festejos religiosos e cívicos uma permeabilidade social bem maior do que as convenções aparentemente podiam indicar. É o que nos mostra Steinen em seu primeiro livro, com as já citadas celebrações da Semana Santa do ano de 1894, o lazer nos passeios públicos e as reuniões de partido nos grêmios recreativos, ocasiões em que "certa gente de pele mais escura" também tomava parte na diversão ${ }^{39}$. A mescla de pessoas e de expressões de cultura nesta época em Cuiabá refletia ainda o modelo colonial formador das cidades erguidas em função da exploração mineradora, da economia agrária e da burocracia portuguesa, numa pujança, segundo Darcy Ribeiro, que de modo algum justificava a visão de um Brasil interiorano com suas principais cidades vivendo isoladas do poder central ou possuindo uma importância menor em relação aos espaços rurais ${ }^{40}$. As festas de cunho oficial e religioso revelavam uma das principais marcas da empresa colonizadora das nações ibéricas, que era justamente a intensa miscigenação com o nativo, cabendo ao colono se apossar de braços e mentes, multiplicando-os para o ganho material desenfreado e assegurando-lhes, em troca, a salvação espiritual pela catequese.

[...] estes instrumentos ideológicos de controle e expressão proporcionaram as bases sobre as quais se edificou a sociedade e a cultura brasileira como uma implantação colonial europeia. Uma e outra, menos determinadas por suas singularidades decorrentes de incorporação de múltiplos traços de origem indígena ou africana, do que pela regência colonial portuguesa que as conformou como uma filial lusitana da civilização europeia ${ }^{41}$.

Deste modo, a música e a dança, ao mesmo tempo em que demarcava os lugares sociais, também se constituía no mais efetivo elemento de ligação entre as

\footnotetext{
${ }^{39}$ STEINEN, O Brasil central. Op. cit., p. 83.

${ }^{40}$ Para Ribeiro, o comando da sociedade colonial brasileira se dava a partir de "grupos eruditos" baseados nestes centros urbanos que, no decorrer desses séculos, "cresceram e se ornaram como portentosos centros da vida urbana, só comparáveis aos do México". Este é um argumento que busca relativizar, entre outras questões, a noção recorrente de uma sociedade colonial brasileira essencialmente rural. Cf. RIBEIRO, Darcy. O povo brasileiro: a formação e o sentido do Brasil. São Paulo: Companhia das Letras, 2006, p. 177.

${ }^{41}$ Ibidem, p. 69.
} 
diferentes categorias de pessoas que habitavam Cuiabá em fins do século XIX, funcionando nas ocasiões permitidas como um amálgama destas relações e imprimindo nelas o modo particular com que os cuiabanos se dedicavam ao lazer em geral e à vida religiosa. A importância de tal convívio para a vida na cidade fez com que Steinen empregasse em sua crônica as seguintes palavras:

"Insipidez" é do que se queixam habitualmente os imigrados de
outras províncias, pertencentes à categoria mais elevada. O natural
do lugar não se compenetra muito dessas impressões alheias e tem a
sua maneira de gozar a vida. Não é possível que haja uma outra
cidade no mundo onde se toque mais música, se dance mais, se jogue
mais baralho que aqui... É impossível, também, que em algum lugar se
alteiem mais frequentemente os estandartes da procissão e se saiba
associar melhor as missas com os prazeres sociais ${ }^{42}$.

Couto de Magalhães também reconheceu nos cuiabanos, além da forte miscigenação, uma predileção especial pela diversão, considerando-os à época "grandes cantores e amigos da dança, como todos os povos proximamente unidos aos indígenas [...], dignos herdeiros dos paulistas que lhes descobriram o solo" 43.

Mais adiante, já nos primeiros anos do século seguinte, outro etnólogo alemão se ocupa do tema. Max Schmidt excursiona, nos primeiros meses de 1901, pelas cabeceiras do rio Xingu (seguindo os passos do seu professor e conterrâneo Karl von den Steinen) e, em seguida, pela região do alto Paraguai, para observar algumas das tribos indígenas destas localidades. Na preparação para os dois destinos, Schmidt hospedou-se nas cidades de Cuiabá e Rosário (atual Rosário Oeste), tendo a chance de conhecer também um pouco da cultura local. Estes eventos estão registrados no livro Estudos de etnologia brasileira: peripécias de uma viagem entre 1900 e 1901, publicado na Alemanha em 1905.

Durante sua estada na capital da província, Schmidt evitou repetir o mesmo relato dos cenários visitados anteriormente por Steinen, por julgar que pouca coisa havia mudado em seis anos. Limitou-se às notícias de que atendera ao convite do presidente da província para um baile no palácio do governo, em homenagem à data da República, e que a sociedade cuiabana passara a ter então o privilégio de passear

\footnotetext{
${ }^{42}$ STEINEN, Karl von den. O Brasil central, Op. cit., p. 68.

${ }^{43}$ COUTO de MAGALHÃES, General. O Selvagem. Belo Horizonte: Itatiaia, 1975, p. 98.
} 
em dois novos jardins públicos, com direito a "concertos gratuitos da banda militar as quartas e sábados à tarde" ${ }^{44}$. Por sorte, Schmidt não foi igualmente econômico ao noticiar os festejos da virada do ano em Rosário, ocasião em que pôde testemunhar expressões que considerou as mais populares e as mais características da região.

Como se comemorou durante quase todos os seis dias que estive em Rosário uma data católica diferente, tive ocasião de observar as danças e os cantos brasileiros.

Já no dia 31 de dezembro de 1900 a festa da Imaculada Conceição foi comemorada solenemente. Assim, para esse dia, uma das famílias transformou a sua mísera cabana em um local de reunião, para o qual em breve convergiu certo número de pessoas de todas as gradações de cor. No interior da casa foi erigida uma espécie de altar. Um caixote de vidro com diversas imagens de santos havia sido enfeitado com papel de cor e fitas de pano; diante dele ardiam duas grandes velas. Uma banda militar, que se pode caracterizar pelo fato de o regente da mesma ser ao mesmo tempo o tangedor dos pratos de cobre e o timbaleiro, começou o início da cerimônia. Seguiram-se longas orações com cantos e música. Dois velhos negros ajoelhavamse diante do altar orientando esses cantos e orações, ficando atrás deles muitas senhoras. Pouco depois fez-se um intervalo em que foi servida aguardente e, então, agrupou-se em torno do altar certo número de dançantes, formando semicírculo para começar a dança do "cururu", tão conhecida em Mato Grosso. Parte dos que dançavam acompanhava na "viola" os versos ali mesmo improvisados pelos cantores. Outra parte dos presentes seguia o ritmo por meio de um pau que roçava numa ripa de bambu, instrumento que denominavam "caracachá". Os dançarinos dispuseram-se em duas filas e, depois, em círculo fechado. Assim foi indo, cada vez mais animadamente, até a madrugada, sendo apenas interrompido o movimento, de vez em quando, para se afinar os instrumentos de corda e dar aguardente aos cantores, o que lhes emprestava novas forças ${ }^{45}$.

Pelas suas descrições, estavam ali presentes praticamente todos os principais elementos característicos do Cururu; a dança em torno do altar, os versos improvisados, o emprego dos mesmos instrumentos musicais de hoje e o uso da cachaça para animar a dança e a cantoria. Schmidt também destaca a participação de uma banda de sopros e percussão que acompanhava as orações e os cânticos no início da cerimônia e ressalta a variedade de raças entre os devotos presentes.

\footnotetext{
${ }^{44}$ SCHMIDT, Op. cit., p. 7.

${ }^{45}$ Ibidem, p. 13-4.
} 
Outra grande novidade para o etnólogo alemão foi a dança que acontecia simultaneamente na área externa da residência que abrigava a festa, além da surpresa em relação ao emprego - corriqueiro, na verdade - dos assentos cobertos de couro como tambores (mochos) e dos pratos e garfos usados como reco-recos (caracachás).

Enquanto se dançava o cururu dentro de casa, lá fora se realizava outra espécie de dança, muito apreciada em Mato grosso, o "siriri", acompanhado também por música e versos cantados. Como não se dispunha de mais instrumentos, cobriram-se algumas cadeiras com couro à guisa de tambores e os pratos fizeram de caracachá, em que tocavam ritmicamente por meio de garfos. Dançarinos e cantores formavam uma roda em que ia constantemente um par para o centro dançar. A dança tinha muitas variações e os movimentos eram cada vez mais rápidos, principalmente no fim, quando os dançarinos já não vinham em par e sim cada um de per si. Um rapazola negro mostrou resistência excepcional, mas a sua companheira preta não ficava atrás em flexibilidade. 0 tempo passou depressa em meio de festas, de modo que entrei no novo ano sem ter dado por isso ${ }^{46}$.

Além do Siriri e do Cururu, Schmidt também conheceu nos festejos de Rosário uma das mais difundidas expressões populares do país, o congo. Chamado por Mário de Andrade de dança dramática, com cantos, figurinos, coreografias, cortejos e embaixadas (cenas teatrais), o congo ou congado rememora ritos e acontecimentos de nações e tribos africanas, como a coroação dos reis do Congo e Angola, tendo a tradição se firmado num contexto em que o português incentivava nos dominados a celebração dos reinados fictícios, inclusive misturando-os ao culto católico, na adoração às figuras da Virgem do Rosário e São Benedito ${ }^{47}$. É resultado, segundo Maynard Araújo, de uma interessante mescla de costumes trazidos pelos escravos negros com elementos da tradição católica ibérica, como as canções de gesta da Europa medieval, representando a luta de mouros e cristãos nas cruzadas ${ }^{48}$. Em Mato Grosso, a dança do congo é hoje celebrada principalmente em devoção a São Benedito

\footnotetext{
${ }^{46}$ Idem.

${ }^{47}$ Este autor ainda assinala: "Num tempo em que a escravaria predominava em número, os reis e rainhas negros, com os quais os padres e senhores condescendiam, a que os chefes profanos da Colônia chegavam a honrar e prestar homenagem como se fossem legítimos, esses reis de fumaça eram bons instrumentos nas mãos dos donos e excelente para-choque entre o senhorio revoltante do senhor e a escravidão revoltada (mais revolta que revoltada...) do escravo". ANDRADE, Mário de. Danças dramáticas do Brasil. Belo Horizonte: Itatiaia, 1982, $2^{\text {a }}$ ed. v. 2, p. 18-20.

${ }^{48}$ ARAÚJO, Cultura popular brasileira. Op. cit., p. 43.
} 
e mantém forte tradição nos municípios de Vila Bela da Santíssima Trindade e Nossa Senhora do Livramento. 0 tema é a disputa entre o rei do Congo e o rei Monarca, que sempre triunfa, com todos celebrando a paz ao final da representação ${ }^{49}$. Por certo, tal riqueza de cores e sons fora causa de forte impressão no viajante alemão, que na ocasião registrou as seguintes linhas:

Já o ano novo começara com um "dia santo", isto é, o dia do Espírito Santo. Desde cedo ouviam-se ruídos de música que vinham de várias direções. Pela tarde, apareceu uma quantidade de negros fantasiados, cantando e tamborilando pelas ruas - iam dançar o "congo". Fizeram parada em uma das ruas para uma demonstração teatral. Para isso dividiram-se em dois grupos, sendo que um deles apresentava o seu rei. Assim, surgiu um arauto de cada um dos grupos. Ambos começaram um diálogo animado em que o rei se intrometeu várias vezes em tom bombástico. Finalmente o partido oposto deu vivas ao rei e continuaram a caminhar ${ }^{50}$.

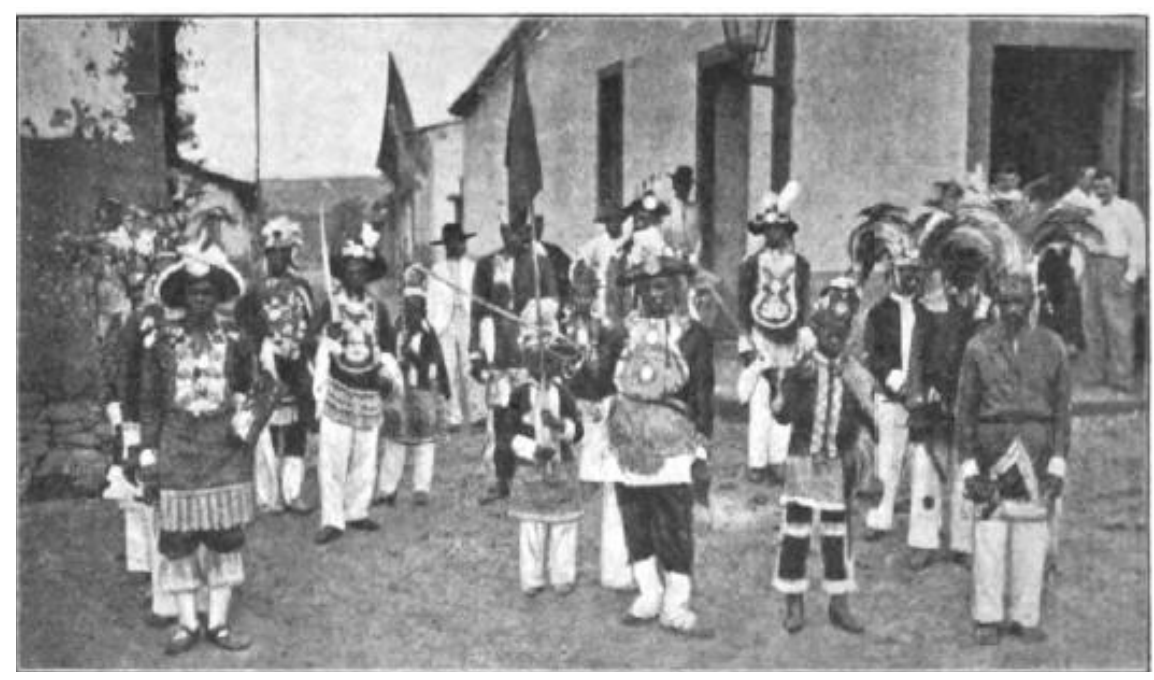

Figura 5: dançarinos do congo em Rosário.

Fonte: Schmidt, 1905

As novidades não pararam aí. Schmidt ainda teve a oportunidade de conhecer na cidade de Rosário outros dois folguedos; um a que chamou "dança de animais" e outro que identificou como "um baile de máscaras". Com base no trecho que transcreveremos a seguir, é possível relacionar o relato do viajante alemão a duas das representações atualmente características do folclore de Mato Grosso. A primeira

\footnotetext{
${ }^{49}$ LOUREIRO, Roberto. Cultura mato-grossense. Cuiabá: Entrelinhas, 2006, p. 81.

${ }^{50}$ SCHMIDT, Op. cit., p. 16.
} 
delas seria a dança boi-à-serra, também representada em outras regiões brasileiras com nomes como bumba-meu-boi, boi-bumbá, boi-de-reis, entre outros. A segunda parece ser a dança dos mascarados, também retratada pelo folclorista mato-grossense Roberto Loureiro, que a relaciona aos folguedos das cavalhadas. Ainda segundo este autor, a dança dos mascarados integra principalmente as celebrações do Divino e São Benedito, sendo ainda praticada na cidade de Poconé, com seus mascarados (adultos e crianças do sexo masculino) realizando danças específicas como o lundu, o carango, cara-dura e a trança-fitas, todas ao som das bandas de música locais¹. Já a animada tradição do boi-à-serra mantém-se nos municípios de Cuiabá e Santo Antônio do Leverger, com destaque para a indumentária do boi (ornada de tecido colorido com enfeites e a cabeça feita da própria caveira do animal), com a caracterização dos demais personagens mascarados (o toureiro, a ema, a onça, entre outros) variando levemente de lugar para lugar ${ }^{52}$. Eis, portanto, o que anotou Max Schmidt:

Numa das noites seguintes pude assistir a uma festa que me interessou bastante, pois realizaram-se danças de animais exatamente como as descreve Avé-Lallemant quando fala do Rio Negro. Primeiro, dois grupos de 6 figuras cada um, estando o primeiro vestido de encarnado e pintado de preto, cuja principal tarefa era recolher as moedas que o público atirava, e bem assim distribuir lenços para que o mesmo público amarrasse neles algum dinheiro. Repentinamente aparece um jaguar, bem vestido, de rabo e orelhas, que provocou terrível alarido entre as crianças negras presentes, de modo que as mães tiveram que sair com elas. 0 jaguar gesticulava furiosíssimo, mas sem sair do ritmo. 0 bobo, munido de duas bexigas de porco entumecidas, devia enfrenta-lo. Depois que desapareceu o jaguar, entrou uma coisa negra de grandes proporções, com chifres e focinho pontudo, a representar um boi. Novamente as crianças presentes puseram-se a chorar. 0 boi começou logo a dançar comicamente, mas sentiu-se mal e foi preciso chamar um médico que o fez restabelecer-se. Os detalhes também correspondiam inteiramente aos relatos que Avé-Lallemant faz em passagens idênticas. Não pude estar presente quando se apresentou, depois, o cavalo, de forma semelhante. Na noite seguinte, a última da minha permanência em Rosário, festejou-se o santo do dia diante da igreja. Os foguetes, inevitáveis em tais ocasiões, riscavam ininterruptamente o céu, assim como os balões de papel e fogos comuns. Ao mesmo tempo houve um baile de máscaras no largo,

\footnotetext{
${ }^{51}$ LOUREIRO, Op. cit., p. 94-6.

52 Ibidem, p. 88.
} 
cujas fantasias em nada se diferenciavam das europeias, pois tinham sido importadas. Um sujeito muito bem fantasiado de chinês que ali vivia certamente nem suspeitava o que o seu traje representava ${ }^{53}$.

Os relatos dos naturalistas e exploradores estrangeiros, que em fins do século XIX e início do XX visitaram Mato Grosso, contêm uma quantidade relevante de informações sobre a música e a dança cultivadas neste contexto, conforme podemos notar no recorte aqui proposto. Em muitos casos, esta literatura se constitui na principal fonte histórica para o conhecimento de práticas que se tornaram o símbolo primeiro de uma identidade regional consolidada muito posteriormente. Sua importância é ainda maior se considerarmos a tendência dos documentaristas locais de ignorar até então as manifestações ligadas às camadas subalternas da população, por considerá-las sem valor artístico algum ou por achar que, prestigiando seus costumes rudes, isso seria um entrave para a tão almejada civilidade da região. Segundo Galletti, o esforço empreendido na construção de uma identidade coletiva em Mato Grosso passaria, nas duas décadas seguintes, primeiramente pela "exaltação à terra e ao homem mato-grossenses", sendo este homem idealizado apenas na figura de alguns dos seus personalidades históricos ${ }^{54}$. As riquezas naturais do lugar e os heróis do passado (bandeirantes, militares e políticos pioneiros) constituir-se-iam, deste modo, no mote encabeçado pelo Instituto Histórico de Mato Grosso (IHMT) e o Centro Mato-grossense de Letras (CML), as duas instituições aglutinadoras da intelectualidade local a consolidar entre os anos 1910 e 1920 um ideário baseado nestes símbolos locais ${ }^{55}$. Esta seria uma das razões para que no discurso regionalista da Primeira República não se levassem em conta as formas de expressão das comunidades pobres da região.

As referências ao cururu e ao siriri, entre outras manifestações culturais populares, estão praticamente interditadas no discurso histórico do IHMT nos anos 1920, até porque eram manifestações tidas como coisa da ralé, identificadas com a "falta" de civilização dos mato-grossenses e, algumas delas, como o cururu e o batuque, eram proibidas na zona urbana e criminalizadas. Nos anos 30, observa-se um apelo, ainda tímido, a estas manifestações como reveladoras da

\footnotetext{
${ }^{53}$ SCHMIDT, Op. cit., p. 16-7.

${ }^{54}$ GALETTI, Lylia da Silva Guedes. Sertão, fronteira, Brasil: imagens de Mato Grosso no mapa da civilização. Cuiabá: Entrelinhas, 2012, p. 321.

${ }^{55}$ Idem.
} 
"alma" mato-grossense, correspondendo ao movimento de valorização das "raízes" culturais brasileiras [...] ${ }^{56}$.

Quanto à crônica dos viajantes estrangeiros do século XIX, não fora ela a única iniciativa de representação deste universo sertanejo, em sua época. Coube também à nascente literatura de caráter regionalista o papel de lançar um olhar pioneiro sobre tais manifestações, reverenciando alguns de seus valores estéticos e dando voz aos seus atores, ausentes tanto nos discursos voltados à construção de uma identidade local quanto na historiografia da época. É o que se pode apreender, a seguir, dos trechos selecionados em uma das mais importantes obras da literatura nacional.

\section{A LITERATURA DE TAUNAY}

Inocência, o romance regionalista de Alfredo d'Escragnolle Taunay, publicado em 1872, principia com a visão dos vastos cerrados do sudeste da província de Mato Grosso, atualmente Mato Grosso do Sul. A partir das imediações do povoado de Santana do Paranaíba, confluência dos caminhos por terra de quem vinha naquela época dos territórios de Goiás, Minas Gerais e São Paulo, esta é a primeira imagem sugerida pelo romancista, a do viajante do século XIX a penetrar gradativamente a natureza exuberante. Por algumas dezenas de léguas, ainda próximo do rio Paranaíba, o viajante podia testemunhar a construção de habitações que iam escasseando até o caminhar de "dias inteiros sem se ver morada nem gente", para daí adentrar o chamado sertão "bruto" 57. Os personagens principais da trama são também sugestivos. 0 fazendeiro viúvo Pereira e sua filha Inocência, prometida em casamento ao vaqueiro Manecão, representariam os códigos e costumes rígidos do sertão. Já Cirino, jovem farmacêutico prático que oferece tratamento aos enfermos daqueles rincões, significaria, no papel do moço de fora (criado nas províncias de São Paulo e Minas Gerais), o contraponto a estes valores, levando adiante um romance proibido que viria a alterar de maneira profunda o equilíbrio daquele lugar. A outra figura estrangeira, a do naturalista alemão Meyer, em missão científica patrocinada pelo seu país, poderia ser entendida como um espelho do olhar de fora, buscando a

\footnotetext{
${ }^{56}$ Ibidem, p. 368

${ }^{57}$ TAUNAY, Visconde de. Inocência. São Paulo: Moderna, 2000, p. 17.
} 
compreensão de uma natureza a ser explorada conforme os referenciais europeus de progresso e civilização daquela época.

É, no entanto, pela breve descrição de alguns dos personagens secundários e de minúcias do cotidiano daquelas vidas que a narrativa de Taunay nos fornece detalhes a respeito das representações sobre a música que pretendemos estudar. Em uma das cenas, os camaradas de Cirino, acomodados em um rancho da propriedade de Pereira, embalam o seu descanso do meio-dia com "monótonas modulações de umas chulas e modinhas, cantadas ao som da viola de três cordas" 58. Teria o instrumento acompanhador destas modas e chulas algum parentesco com as violasde-cocho de hoje, empunhadas pelos ribeirinhos da região? Possuiriam as cantorias dos camaradas de Cirino algum ponto de contato com gêneros musicais hoje considerados típicos de Mato Grosso? Couto Magalhães é um dos folcloristas desta mesma época a mencionar uma viola de três cordas nas mãos de indígenas que cultivavam o Cururu e o Cateretê, prática certamente tomada dos colonos do centrosul brasileiro ${ }^{59}$. Sabe-se também, graças a pesquisas de campo realizadas na década de 1940 por Maynard Araújo, que na região paulista do médio Tietê o Cururu era acompanhado por uma viola bastante rústica, conhecida por cocho, juntamente com os demais instrumentos que são ainda hoje empregados nas práticas remanescentes do gênero paulista ${ }^{60}$. Estes seriam indícios, nas práticas do cancioneiro rural cultivado à época no centro-sul brasileiro, do emprego de uma variedade de instrumentos cordofones que eram aparentados das violas de uso mais comum.

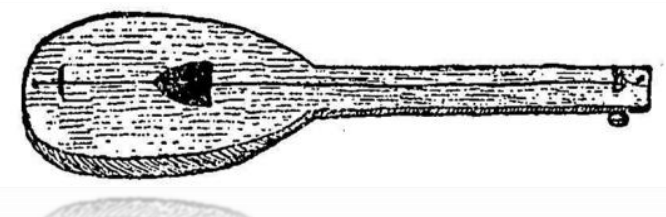

Figura 6: instrumento de uma cordaobservado por Maynard Araújo na década de 1940, também chamado "cocho"

Fonte: Araújo, 1973

\footnotetext{
58 Ibidem, p. 73.

${ }^{59}$ COUTO DE MAGALHÃES. Anchieta e as raças e as línguas indígenas. Op. cit., p. 23.

${ }^{60}$ Em 1947, o folclorista piracicabano registrou, no município de Tietê, o uso de um instrumento de nome cocho feito de uma só corda (figura 6). No mesmo ano, teve notícias da existência, em uma fazenda do município de Pereiras, próximo a Tatuí, de um cocho de quatro cordas e com a caixa de ressonância e braço escavados a partir de uma única peça de madeira. As similaridades no nome, formato e construção destes instrumentos com as violas-de-cocho mato-grossenses atestam a ligação histórica das práticas do Cururu de São Paulo com as de Mato Grosso. Cf. ARAÚJO, Cururu rural. Op. cit., p. 36 e 58.
} 
Do mesmo romance de Taunay destacaríamos também a cena em que "umas mulheres com uns homens", de passagem pela propriedade de Pereira, são recebidos com reserva pelo fazendeiro. A filha Inocência pergunta ao pai a razão para não serem convidadas a ocupar as dependências da casa onde se sentavam as famílias, ao que Pereira responde: "Não, Nocência, são mulheres perdidas, de vida alegre" [...]. Em seguida, a filha reconhece um tanto envergonhada que as coitadas "caíam tontas no chão... pitavam e cantavam muito alto com modos tão feios [...]" 61. Em certo sentido, mesmo levando em conta os padrões de moralidade há muito implantados pela colonização, a passagem representa a rejeição daquela sociedade aos excessos relativos às suas formas antigas de lazer, demonstrando o modo como uma parte destes costumes passara a ser condenada pelos códigos de conduta da época. A respeito destes juízos, Luiza Volpato comenta que os ideais de progresso da segunda metade do século XIX, baseados em modelos adotados no centro-sul do País, fizeram com que os modos de vida cultivados pelas camadas populares da região passassem a ser considerados "manifestações de baixo grau de civilização", sendo vários os casos de repressão a elas pelo poder local. Estes novos parâmetros de sociabilidade alteraram, inclusive, as relações dos homens pobres com o trabalho, uma vez que todos deveriam cultivar bons modos para não cair na marginalidade ${ }^{62}$. Por outro lado, o prestígio das festas junto ao povo era garantido justamente pela animação da dança e pelos gestos de devoção religiosa expressos em folguedos como o do Cururu. Tanto que Manecão, em outra cena do livro, discute os preparativos do seu casamento lembrando que não poderá faltar na festa "um cururu valente" 63.

Uma obra com personagens de ficção como Inocência, mesmo quando se propõe a traçar um retrato acurado da realidade vivida, está sujeita evidentemente a certa dose de invenção por parte do seu autor, podendo até significar uma junção aleatória de cenas e circunstâncias vividas em cenários distintos. Mas estas não seriam razões suficientes para refutá-la como fonte para o conhecimento do tema, uma vez que estariam em conformidade com o modelo de investigação descrito por Ginzburg, que leva o historiador, através de indícios indiretos (como mitos, emblemas

\footnotetext{
${ }^{61}$ Ibidem, p. 100.

${ }^{62}$ VOLPATO, Op. cit., p. 229.

${ }^{63}$ TAUNAY, Op. cit., p. 123.
} 
e sinais), a se alimentar de rastros e de outros elementos imponderáveis, à maneira do psicanalista que chega a um diagnóstico a partir dos sintomas de comportamento de seu paciente ${ }^{64}$.

Todas as referências do romance de Taunay a práticas musicais, a costumes e a festejos locais são bastante coerentes com o que se sabe a respeito da vida rural e dos povoados da parte sul de Mato Grosso, no século XIX. Isto se deve principalmente ao fato de o autor ter travado contato direto com aquela realidade, integrando como segundo-tenente a comissão de engenheiros das tropas brasileiras que combateram na Guerra do Paraguai. Taunay foi um dos protagonistas de um dos episódios mais dramáticos do conflito, a Retirada da Laguna, quando a coluna comandada pelo coronel Carlos Morais Camisão - partindo do povoado de Miranda, em janeiro de 1867 - penetrou o território paraguaio e sofreu severos ataques das forças inimigas ${ }^{65}$.

\section{REGULAMENTOS}

Não distante dos enredos e imagens da ficção de Taunay e da narrativa dos cronistas oriundos do Velho Mundo, os processos criminais e os relatos das ocorrências policiais deste período fornecem um vasto material para a análise do perfil dos representantes das expressões musicais aqui estudadas. Também as Posturas Municipais, conjuntos de leis que regulavam os mais diversos aspectos do convívio social urbano no Brasil do século XIX, constituem importante fonte de informação acerca do modo como eram aceitas as rodas de Cururu e de Batuques na Província. Isto porque o aumento da população e a diversidade da economia nas principais cidades passaram a exigir uma série de medidas sanitárias, de segurança e conveniência, normatizando a vida pública "através de uma constante vigilância sobre

\footnotetext{
${ }^{64}$ Ginzburg destaca, como exemplo, a bem sucedida conjunção de "erudição e imaginação, provas e possibilidades", da história privada de Arnaud du Tilh, Martin Guerre e sua mulher Bertrande, na França do século XVI, contada por Natalie Zemon Davis. Por conta do desaparecimento das atas do processo contra Arnaud du Tilh, Ginsburg observa que N. Davis não teve outro caminho senão o de tomar as "reelaborações literárias" do juiz Jean de Coras e de Le Sueur como ponto de partida. Mas a historiadora foi muito além, ao buscar preencher as lacunas documentais com dados de outros processos e outras pessoas da região, estabelecendo elos conjecturais por intermédio de uma narrativa de fundo também literário. Cf. GINZBURG. Carlo. Mitos, emblemas, sinais: morfologia e história. São Paulo: Companhia das Letras, 1989, p. 150; A micro-história e outros ensaios. Lisboa: Difel, 1989, p. 182. Ver também: DAVIS, Natalie Zemon. $O$ retorno de Martin Guerre. Rio de Janeiro: Paz e Terra, 1987.

${ }^{65}$ Este episódio foi retratado na literatura nacional pelo referido autor, em 1874. Cf. TAUNAY, Visconde de. A retirada da laguna: episódio da guerra do Paraguai. São Paulo: Melhoramentos, 1952.
} 
os atos e comportamentos dos indivíduos" 66. Luiza Volpato e Cleber Pereira Júnior são dois dos pesquisadores que analisaram parte desta documentação, com o fim de conhecer o cotidiano dos escravos e demais trabalhadores pobres (militares de baixa patente, camaradas, pequenos sitiantes e agregados) da região de Cuiabá, na segunda metade do século XIX. São estudos que destacam a preocupação das autoridades locais com a repressão aos tumultos e agressões físicas que eram normalmente creditados aos hábitos considerados não civilizados das classes subalternas, ao mesmo em tempo em que revelam as condições de vida e as relações de proximidade estabelecidas entre estas pessoas através do lazer e do trabalho ${ }^{67}$.

Da documentação em arquivo que também tivemos acesso, é possível notar a proximidade existente entre as culturas destes segmentos, como no caso relatado pelo chefe de polícia Jesuíno Souza Martins ao presidente da Província Antonio Pedro de Alencastro, dando conta em agosto de 1860 da prisão de Francisco de Faria, Gertrudes da Silva, Josefa Maria, Francisca Corrêa e Maria José (todos livres), juntamente com os escravos João e Gregório (pertencentes ao Reverendo José Jacinto e ao Alferes João Poupino Caldas, respectivamente), "por estarem formando motins na Rua do Bahú com danças de batuque" 68. Em outro relatório de dezembro de 1860, o mesmo chefe de polícia anuncia "que fora solto e entregue à sua senhora Da. Mariana Rosa o escravo Mathias, preso na noite de 15 do corrente por ser encontrado em uma função de cururu na Rua da Sé sem bilhete da dita senhora" 69.

Com estes dois exemplos, os Batuques de origem negra e o Cururu de origem cabocla, notamos uma associação direta das danças praticadas pelos habitantes pobres em geral à ideia de contravenção, sendo o controle das autoridades locais exercido tanto através da proibição de tais funções quanto pela concessão de

\footnotetext{
${ }^{66}$ SCHMACHTENBERG, Ricardo. Código de posturas e regulamentos: vigiar, controlar e punir. Anais do IX Encontro Estadual de História. Porto Alegre, RS jul 2008 UFRS/ANPUH-RS 13 p. Disponível em <http://eeh2008.anpuhrs.org.br/resources/content/anais/1209158027 ARQUIVO CODIGOSDEPOSTURAS.pdf> Acesso: 28/08/2014.

${ }^{67}$ VOLPATO, Op. cit. Ver também: PEREIRA JR, Cleber Alves. O código de posturas e o futuro Cururu oitocentista. Anais do XXV Simpósio Nacional de História. Fortaleza, CE 2009. 8p. Disponível em $<$ http://anpuh.org/anais/wp-content/uploads/mp/pdf/ANPUH.S25.1325.pdf> acesso: 28/08/2014.

${ }^{68}$ Ofício ${ }^{\circ} 130$ do Chefe de Polícia Jesuíno de Souza Martins ao Cel. Antonio Pedro de Alencastro. Cuiabá, 24 de agosto de 1860. Acervo: APMT; CAIXA 1860 A-4.

${ }^{69}$ Ofício $n^{\circ} 310$ do Chefe de Polícia Jesuíno de Souza Martins ao Cel. Antonio Pedro de Alencastro. Cuiabá, 18 de dezembro de 1860, Acervo: APMT, CAIXA 1860 B-2.
} 
autorização por escrito. Citando o caso do escravo Benedito - acusado em 1866 de ferir o cabo Ricardo Fernandes Paes, em reação à prisão decretada pelo militar, por se encontrar em uma função de Cururu que não havia sido permitida pelas autoridades Pereira Júnior também ressalta que, mesmo proibidas ou controladas através de licenças expressas, tais "brincadeiras" mantiveram-se presentes no cotidiano das pessoas $^{70}$.

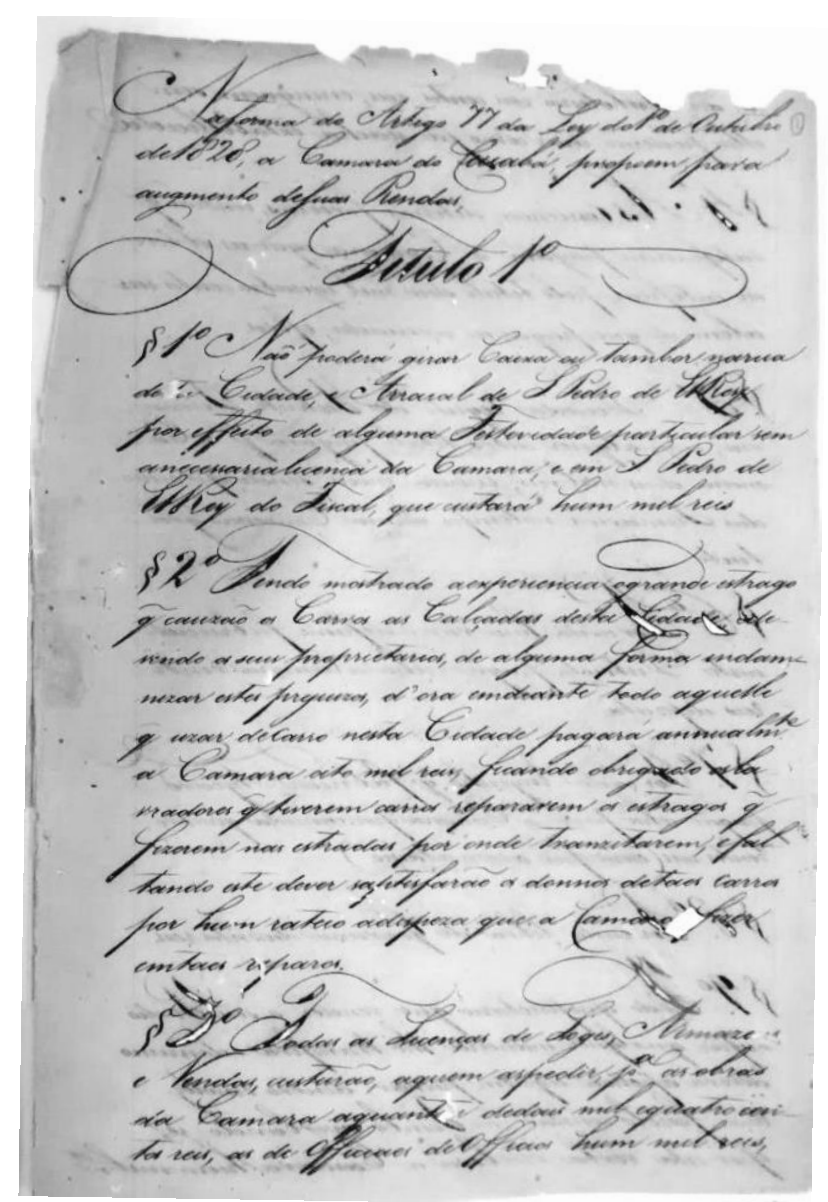

Figura 7: Posturas da Câmara de Cuiabá (1831) Fonte: $A P M T$

As ações que buscavam reprimir os folguedos tinham respaldo nas Posturas Policiais editadas pela Câmara Municipal de Cuiabá, que estabeleciam punições que iam de multas em dinheiro à destruição dos instrumentos musicais, de açoites ao encarceramento, a depender do grupo social a que pertenciam os infratores e o

\footnotetext{
${ }^{70}$ Sumário de culpa produzido contra o escravo Benedito. Acervo APMT; Fundo: Judiciário; Ano: 1866. Apud PEREIRA JR, Op. cit. p. 7.
} 
envolvimento de cada um no delito. É o que estabelecia o parágrafo décimo da Lei de 04 de janeiro de 1831:

Sendo mais conveniente prevenir os males que remediar os danos que continuadamente resultam dessas funções de batuques, cururus e tambaques, cuja consequência são pancadas, facadas e mortes, como por muitas vezes têm acontecido, d'ora em diante ficarão proibidas estas funções; e aquele proprietário ou inquilino que [ilegível] ou consentir pagará para as obras da Câmara $30 \$ 000$ ou trinta dias de prisão; sendo na rua, serão quebrados os instrumentos e presos os da função; sendo livres, por 30 dias; e sendo escravos, 100 açoites e metidos presos até os senhores ${ }^{71}$.

O que também chama a atenção no conteúdo do documento, além do intuito de prevenir as frequentes "pancadas, facadas e mortes" entre os participantes, são o três tipos de danças que eram mal vistas por aquelas autoridades: os "batuques, cururus e tambaques". Os mesmos exemplos citados nos relatos de Ferreira Moutinho, 38 anos mais tarde, e Steinen, 56 anos depois, atestando o longo período de proximidade existente entre negros cativos e pessoas livres e pobres do lugar. Ao desprezo das autoridades por tais práticas somava-se a pecha de desocupados atribuída àqueles homens e mulheres, que eram, por necessidade, levados a um convívio estreito com os negros cativos. Costumavam folgar nas mesmas festas e cultivavam, muitas vezes, as mesmas devoções, estabelecendo vínculos pelo sexo, pela amizade e pela rivalidade, numa constante disputa pelos mesmos espaços de sobrevivência. Com os delitos praticados em comum, tinham a sua imagem diretamente associada aos principais problemas de violência que afligiam as cidades e assim suas expressões culturais eram alvo de censuras ainda maiores ${ }^{72}$.

Para Sylvia de Carvalho Franco, que estudou o quotidiano dos trabalhadores livres e pobres da região cafeeira do Vale do Paraíba, esta mesma violência emerge, por outro lado, como um padrão de comportamento face ao ajustamento possível do homem pobre a uma sociedade cada vez mais fundamentada no trabalho escravo e na grande propriedade fundiária. Com a introdução de relações de trabalho não mais voltadas apenas à sua própria subsistência e a gradativa interdição da ocupação da

\footnotetext{
${ }^{71}$ Posturas Policiais da Câmara Municipal da Cidade de Cuiabá, de 04 de janeiro de 1831. Acervo: APMT, PM 02, Caixa 1 (grifos meus).

${ }^{72}$ VOLPATO, Op. cit., p. 208.
} 
terra, do modo como havia originalmente se habituado, resta ao caipira um dos poucos atributos pelos quais ele se vê em condições de lutar: a reputação pessoal expressa nas afirmações de valentia sobre os seus pares ${ }^{73}$. Na análise da historiadora, o inconformismo deste indivíduo, impossibilitado de contar com algo além da força bruta, encontrará "sua expressão mais livre na esfera menos regulamentada da sociedade, a vida lúdica", sendo através do desafio (e a palavra desafio pode aqui ser empregada tanto no sentido das pelejas que resultavam em ofensas físicas quanto para os folguedos praticados em grupo, como as troças e desafios cantados) que este homem irá preservar a honra, reafirmando perante todos sua coragem e valentia ${ }^{74}$.

Ainda sobre a legislação e o papel das autoridades na ordenação do lazer das classes pobres, na cidade de Cuiabá do século XIX, Pereira Júnior identifica no Projeto de Posturas de 1873 uma importante mudança em relação às Posturas Policiais de 1831. Pela lei posterior, estariam liberadas as funções de Cururu, desde que os seus praticantes comprovassem o pagamento de uma licença para a respectiva prática ${ }^{75}$. No entanto, é possível identificar no já citado relatório de 18 de dezembro de 1860, do chefe de polícia Jesuíno de Sousa Martins, um caso em que as proibições ao Cururu expressas nas Posturas de 1831 podiam ser substituídas por autorizações escritas. Diz o referido relatório que a prisão do escravo Mathias "por ser encontrado em uma função de cururu" dava-se pelo fato do mesmo não portar o "bilhete" da sua senhora, Dona Mariana Rosa. Assim, mesmo proibidas ou controladas através de autorizações expressas, as rodas Cururu, Siriri e Batuques, que eram tachadas de insípidas, barulhentas e violentas, continuariam a se formar ao longo do século XIX.

\section{RIBEIRINHOS}

Outro termo atribuído com frequência ao homem pobre da região é o de ribeirinho, designação determinada obviamente pelos fatores característicos do seu meio natural e pelos traços mais marcantes da sua formação étnica. Sua explicação, segundo Martina Neuburger, é a de uma forma de vida rural ou semi-rural

\footnotetext{
${ }^{73}$ FRANCO, Maria Sylvia de Carvalho. Homens livres na ordem escravocrata. São Paulo: Ed Unesp, 1997, p. 113.

${ }^{74}$ Ibidem, p. 62

${ }^{75}$ Projeto de Posturas da cidade de Cuiabá, ano de 1873. Acervo: APMT; Câmara, Códigos de Posturas. Apud PEREIRA JR. Op. cit. p. 4.
} 
"intimamente atrelada ao contato com o rio", tendo como base uma economia de subsistência de certa forma variada76. Para Ana Carolina da Silva Borges, que emprega em seu estudo a palavra "ribeirinho" entre aspas, trata-se de um grupo de pequenos trabalhadores rurais livres "que possuíam relativa autonomia em relação às fazendas e aos engenhos e usinas", e que também praticavam uma agricultura e uma caça e pesca voltada para seu próprio sustento ${ }^{77}$. Assinala ainda a autora que, não sendo esta uma autodesignação, uma vez que estes homens se viam internamente como camaradas, lavradores, criadores, pescadores, oleiros, artesãos, entre outros tantos ofícios, a figura do "ribeirinho" da região resulta de uma construção externa, presente nos relatos de estrangeiros e autoridades locais, tanto na forma descrita dos seus modos de vida quanto na utilização do termo em si ${ }^{78}$.

Esta seria uma imagem também intrinsicamente atrelada à figura do índio e seus descendentes, dada à sua familiaridade com o regime das águas e o seu alto grau de miscigenação. No relato da expedição Langsdorff em terras mato-grossenses, Florence ressalta a enorme desproporção entre o número de brancos e a maioria da população formada de índios, negros e mestiços. Diz o francês que, ao chegar a algumas das principais cidades da Província, como Albuquerque, Vila Maria e Vila Bela, avistara não mais do que uma família ou conjunto de seis ou sete pessoas de pele branca, em contraste com o restante dos habitantes, cujo destaque era o caburé, mistura do negro com o índio ${ }^{79}$. Em Cuiabá, Florence também descreve o "caminho de meio quarto de légua que vai ter ao porto", onde se avistava poucas casas, algumas canoas, índios, negros, caburés e mulatos ${ }^{80}$. Já no início do século seguinte, Schmidt também destaca o predomínio dos mestiços de pele mais escura, descrevendo as "gradações de cor" dos participantes de uma função de Cururu em Rosário ${ }^{81 .}$

Neste sentido, o modo como estes homens se relacionavam com o solo ocupado passa a ser também um dos temas de interesse dos viajantes. Bartolomé

\footnotetext{
76 NEUBURGUER, Martina. Engenho Velho e Miguel Velho: comunidades ribeirinhas em transformação. Cuiabá: Cadernos do NERU/UFMT, n 3, Set. 1994, p. 109.

${ }^{77}$ BORGES. Ana Carolina da Silva. Nas margens da história: meio ambiente e ruralidade em comunidades "ribeirinhas" do Pantanal Norte: 1870-1930. Cuiabá: Ed UFMT/ Carlini \& Caniato, 2010, p. 42.

78 Ibidem, p. 43.

${ }^{79}$ FLORENCE, Op. cit., passim.

${ }^{80}$ Ibidem, p. 124.

${ }^{81}$ SCHMIDT, Op. cit., p. 14.
} 
Bossi relata, em 1863, as facilidades para obter-se o alimento diário através da coleta de peixes, sempre abundante nos rios mato-grossenses. Uma conveniência que levava a província a ter, segundo o explorador, uma agricultura bastante incipiente ${ }^{82}$. Tal estilo de vida fez com que muitos assentassem suas casas nos barrancos desses rios e vivessem de pequenas roças, artesanatos, trabalhos esporádicos, incluindo, claro, a pesca. Esta era também a visão de Jacomo Vicenzi, cônego residente no Rio de Janeiro e que em 1918 empreendera viagem de treze meses pela região:

Os habitantes por aqui são todos adventícios, ou melhor, vagabundos, no bom sentido da palavra. Com efeito, eis como eles costumam estabelecer-se: uma família mete-se numa canoa, desce o rio, atraca no ponto que lhe apraz, sem indagar a quem pertence, semeia alguns cereais, planta um pouco de mandioca e, com meia dúzia de forquilhas faz uma choupana, à toa, que as águas, ao engrossarem, levam por ali abaixo... E, na verdade, vejo, em passando, essas choças prestes a serem invadidas, e arrebatadas; em muitos a água entrou ou está a entrar, não de surpresa, e sim maciamente. E se isto se der? Recorrem de novo à barquinha, sem motivo de lágrimas pelos edifícios que acabam de perder ${ }^{83}$.

Em 1872 o então presidente da Província, tenente-coronel Francisco José Cardoso Júnior, ao relatar os problemas enfrentados na produção e comércio agrícola, expressa-se do mesmo modo perante a Assembleia Legislativa, lamentando as infrutíferas ações de governo no sentido de implementar na região uma economia empreendedora:

[...] o que mais afeta o progresso da lavoura no Mato grosso é a indolência e a inércia. Aqui o proletário não pensa no dia de amanhã. Hoje pesca; e como o resultado da pesca dá-lhe para viver dois ou três dias, dorme no quarto e torna à pesca no seguinte. Os rios Cuiabá, Paraguai e outros, que contém a Província, são abundantíssimos em pescado. Parece um bem, e realmente o é, debaixo de certo ponto de vista, mas converte-se num grande mal, porque, pode-se dizer sem medo de errar, alimenta a ociosidade em que vive e a que se abandona a maior parte da população. [...] A prova evidente dessa descrença está no fato de ter o Governo Imperial, em circular de 22 de julho do ano passado e sob condições facílimas, oferecido instrumentos e mudas de sementes aos lavradores,

\footnotetext{
${ }^{82}$ BOSSI, Bartolomé apud Siqueira, Op. cit., p. 141.

${ }^{83}$ VICENZI, Jacomo. Paraíso verde: impressões de uma viagem a Mato Grosso em 1918. Ed. do autor s.d., p. 79.
} 
mediante uma pequena retribuição. Fiz o oferecimento chegar ao conhecimento de todos, mas ninguém se quis utilizar dele ${ }^{84}$.

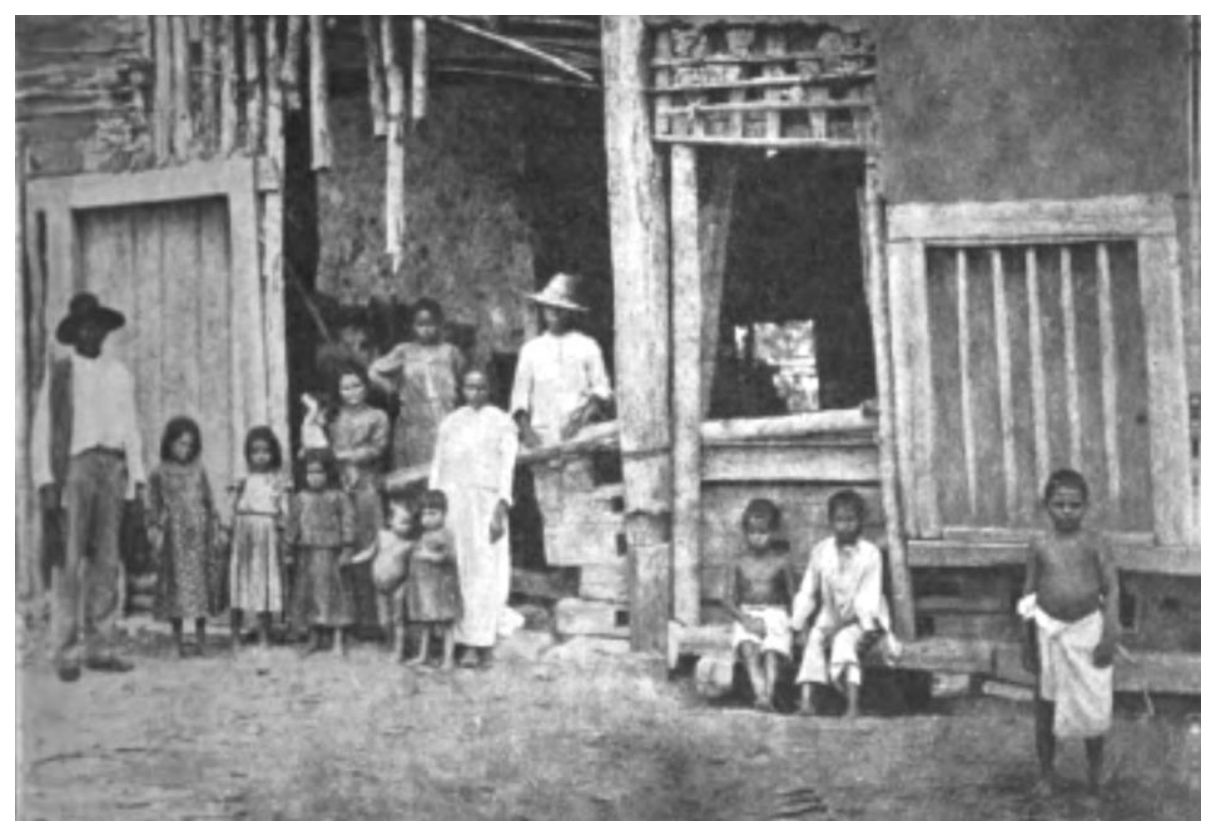

Figura 8: Moradores das margens do Cuiabá Fonte: Schmidt, 1905

As representações em torno do termo "ribeirinho" emergiram, segundo a análise de Borges, inicialmente de um olhar estrangeiro e foram imediatamente incorporadas às narrativas oficiais, com seus líderes políticos delas se valendo para a legitimação de seus projetos de progresso, exploração e regulamentação territorial ${ }^{85}$. Todavia, essa imagem singular de uma camada nada homogênea, com sua variada gama de designações relativas ao trabalho e suas inter-relações étnicas, acabou por se ressignificar ao longo das três últimas décadas do século $\mathrm{XX}$, através de um discurso consagrador de sua cultura e como uma das principais marcas identitárias dos estados de Mato Grosso e Mato Grosso do Sul.

\section{O HOMEM, A TERRA E A SUA CULTURA}

O Cururu é, para Maynard Araújo, uma das mais antigas danças populares brasileiras, sendo os bandeirantes os primeiros responsáveis pela sua difusão por

\footnotetext{
${ }^{84}$ CARDOSO JÚNIOR, Francisco José. Relatório apresentado à Assembleia Legislativa da Província de Mato Grosso, no dia 4 de outubro de 1872. Rio de Janeiro: Typografia do Apóstolo, 1873, p. 87.

${ }^{85}$ BORGES, Op. cit., p. 220.
} 
toda a área de expansão da Capitania de São Paulo. Quando partiam da vila de São Paulo de Piratininga, "descendo o Anhembi, nos pousos e ranchos dançavam o Cururu, e desta forma, a dança, inicialmente aprendida com os jesuítas, foi sendo disseminada por toda a Paulistânia [...]" 86. Esses sertanistas, que entre os séculos XVI e XVII penetraram as florestas e os campos do Brasil colonial na captura do gentio, na busca de minérios preciosos e no extermínio dos quilombos, eram em sua grande maioria mestiços gestados pelo colono branco com a mulher índia. Mamelucos acostumados "à bruteza selvagem da selva tropical, herdeiros do saber milenar acumulado dos índios sobre terras, plantas e bichos", que fizeram de suas características físicas e de suas técnicas de domínio da natureza o grande motor da expansão portuguesa pelo interior ${ }^{87}$. 0 termo Paulistânia diz respeito, justamente, a este esforço expansionista; foi cunhado em 1946 por Joaquim Ribeiro, como referência à extensa região do centro-sul brasileiro por onde penetrou o bandeirismo e onde se fixaram os modos de vida e os valores espirituais das populações oriundas do planalto piratiningano ${ }^{88}$.

Outro fator de ampliação destes domínios foram monções do Cuiabá, as expedições fluviais que nos séculos XVIII e XIX interligaram as capitanias de São Paulo e Mato Grosso. Sua história constitui-se num desdobramento imediato da história da empresa bandeirante, já que a descoberta das minas do Coxipó-Mirim, em 1719 por Pascoal Moreira Cabral, atraiu uma grande quantidade de sertanistas e mareantes (como eram também chamados os camaradas que atuavam na navegação dos rios da região), vindos principalmente da capitania de São Paulo. Inicialmente voltados à necessidade de escoamento da produção aurífera e provimento da vida nas minas, os trajetos adotados passaram também a servir regularmente o comércio em geral e a estrutura militar local, durante todo o período entre a segunda década do século XVIII e a primeira metade do século XIX, contribuindo cada vez mais para a afluência de trabalhadores oriundos de áreas mais povoadas ${ }^{89}$.

\footnotetext{
${ }^{86}$ ARAÚJO, Cururu rural. Op. cit., p. 66 (grifos meus).

${ }^{87}$ RIBEIRO, Darcy. Op. cit., p. 97.

${ }^{88}$ RIBEIRO, Joaquim. Folklore dos bandeirantes. Rio de Janeiro: José Olympio, 1946, p. 185-6.

${ }^{89}$ HOLANDA, Sérgio Buarque de. Monções. São Paulo: Alfa-Ômega, 1976, p. 47.
} 


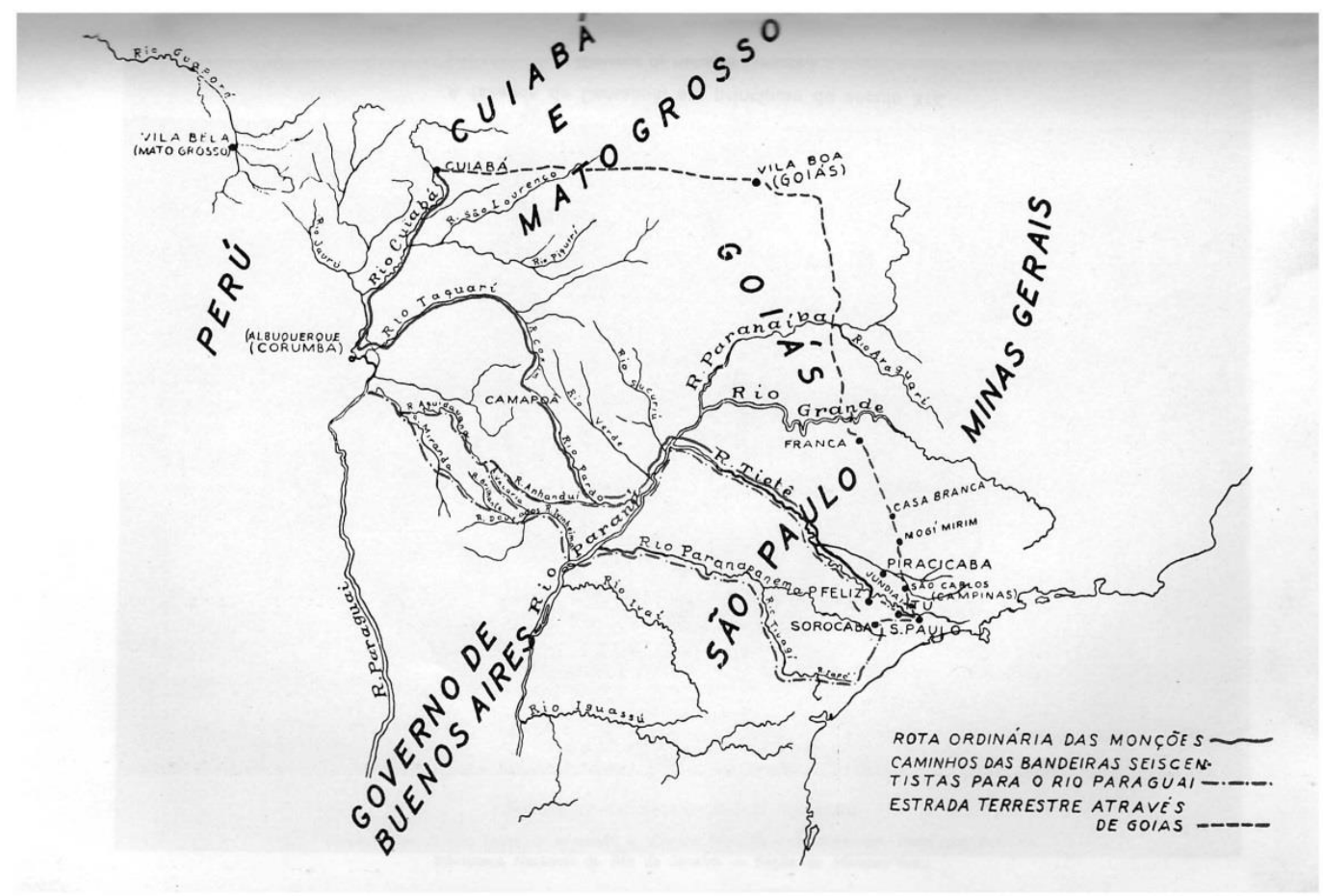

Mapa 1: Rota das monções

Fonte: Holanda, 1976

Neste processo, onde os vários saberes nativos mantidos por estes homens (o bilinguismo; a coleta, o cultivo e o preparo dos alimentos; a cooperação vicinal através dos mutirões, entre outros) continuaram se somando a valores e técnicas adventícias (dentre eles, o uso maior de manufaturados; incremento da exploração do solo e do comércio; o transporte fluvial e terrestre como negócio), a sociedade se tornou mais estratificada, tendo de um lado as vilas e as fazendas abastadas, com suas relações de trocas cada vez mais intensas e, de outro, o pequeno assentamento rural, baseado no provimento mínimo das suas necessidades materiais. Este último foi o responsável, no dizer de Antônio Cândido, pela difusão de um "lençol de cultura caipira" que se estendeu, com algumas variações locais, pelas capitanias de Minas, Goiás e Mato Grosso e unificou os seus costumes e modos de subsistência a partir da fixação ao solo dos herdeiros do bandeirismo. Segundo este autor, era possível notar por toda parte da Paulistânia, "as mesmas práticas festivas, a mesma literatura oral, a 
mesma organização da família, os mesmos processos agrícolas, o mesmo equipamento material" 90.

Ainda no caso específico das representações em música e dança ligadas à população pobre da região, parece não haver dados suficientes para o estabelecimento de um fio condutor ao longo de toda a sua história. Com base nos registros feitos no século XIX, sabemos do seu cultivo entre algumas das etnias indígenas que experimentaram um maior contato com a cultura do colono, da sua incorporação aos costumes das comunidades de negros na região, assim como temos notícia da mesma presença na cultura dos descendentes dos sertanistas paulistas. 0 que, porém, nos falta é uma informação consistente acerca dos seus primórdios. Consultando os autores que se empenharam na investigação de um possível cancioneiro próprio dos bandeirantes, Joaquim Ribeiro reconhece que não há vestígio algum que confirme a existência de uma produção desta espécie. 0 mesmo autor admite que nada avançou no sentido de se confirmar a hipótese formulada por Sílvio Romero, na qual os bandeirantes cultivaram gestas narrando sua coragem e seus feitos $^{91}$. Tampouco os estudos acerca das monções revelam cenas em que seus tripulantes portam instrumentos musicais e representam em canto a realidade das expedições fluviais. É razoável supor que as condições peculiares destas viagens - o exíguo espaço nas canoas e os enormes perigos enfrentados na transposição de cachoeiras e nos ataques de animais e índios, além dos longos trechos percorridos a pés descalços pelos bandeirantes que ainda carregavam seus suprimentos - não permitissem aos seus integrantes ocupar-se efetivamente da música. Por outro lado, ao mesmo tempo em que entrava em declínio a atividade das entradas e bandeiras e se estabelecia uma regularidade maior na navegação fluvial, os sertanistas iam cada vez mais se fixando em lugares que antes eram apenas de passagem. É neste sentido que, ao investigar este processo de transformação no espírito pessoas que viviam das monções, Buarque de Holanda pondera:

As primeiras monções do Cuiabá deveriam recrutar a mesma gente fragueira e turbulenta que constituíra as bandeiras do século XVII. Todavia os elementos de que agora dispõe o sertanista para alcançar

\footnotetext{
${ }^{90}$ CÂNDIDO, Antônio. Os parceiros do Rio Bonito: estudo sobre o caipira paulista e a transformação dos seus meios de vida. São Paulo: José Olympio, 1964, p. 61.

${ }^{91}$ RIBEIRO, Joaquim. Op. cit., p. 120.
} 
sua terra de promissão, vão deixar menor margem ao capricho e à iniciativa individuais. É inevitável pensar que o rio, que as longas jornadas fluviais, tiveram uma ação disciplinadora e de algum modo amortecedora sobre o ânimo tradicionalmente aventuroso daqueles homens ${ }^{92}$.

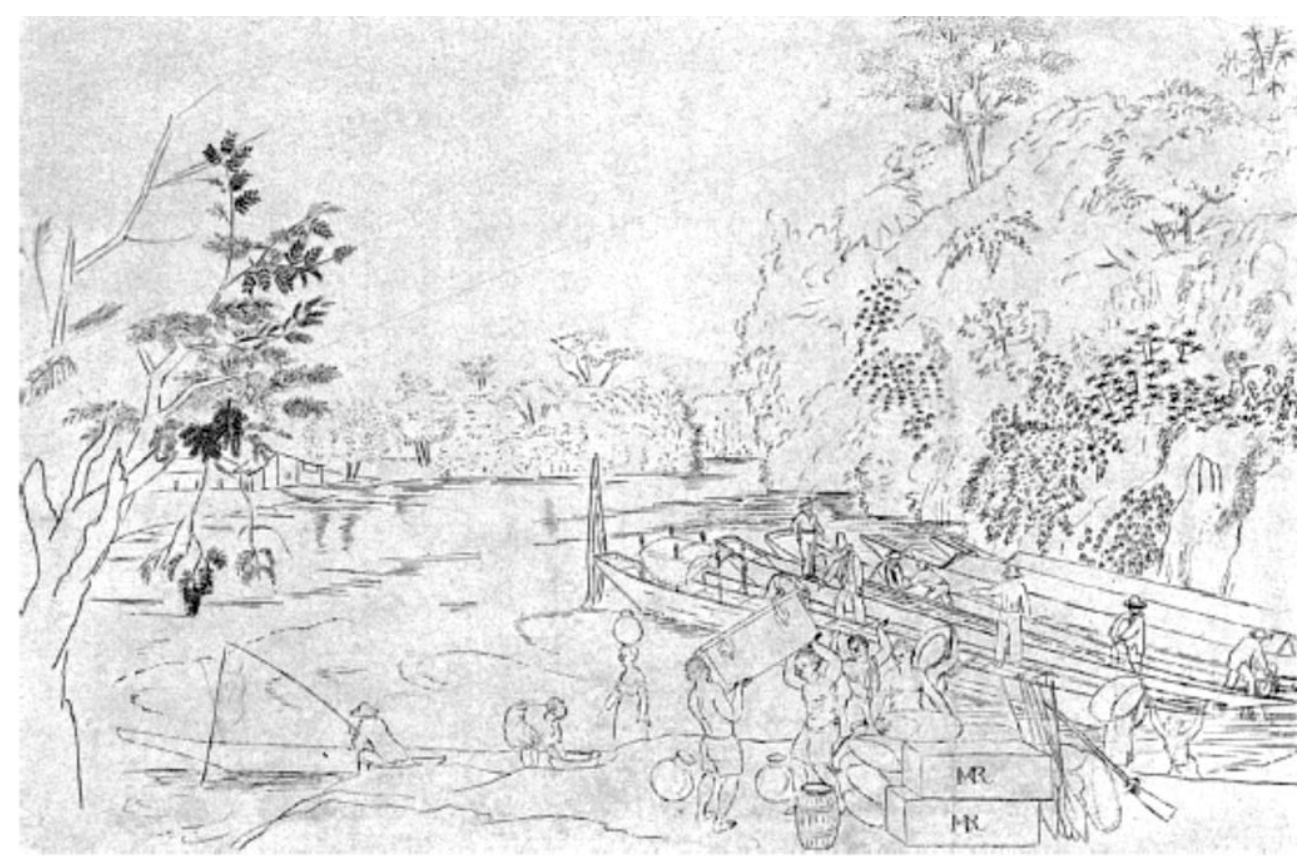

Figura 9: Florence, Expedição de Porto Feliz para Cuiabá Fonte: Florence, 2007

Igualmente indicativo é o relato de Florence, quando membro da expedição Langsdorff, não só pela menção ao lazer com música desfrutado pelos viajantes em locais de pouso como também pela presença de negros nestes ambientes. Após um trecho percorrido em canoa entre Santos e Cubatão, no ano de 1825, o cronista francês retrata um batuque entre camaradas tropeiros.

Parti de Santos com alguns dias de avanço sobre meus companheiros a fim de mandar preparar cômodos em Cubatão e contratar com antecedência algum tropeiro, que se encarregasse de transportar para São Paulo toda a bagagem pertencente à comissão. Embarqueime numa canoa feita dum só pau e tripulada por dois negros remadores. [...] Presenciando a atividade que reinava em Cubatão, [...] vi diariamente chegar três a quatro tropas de animais e outras tantas partirem. [...] Acontece que quando muitas delas ali se reúnem, os camaradas se congregam todos para dançarem e cantarem a noite inteira o batuque. Gritam a valer e com as mãos batem

92 HOLANDA, Sérgio Buarque de. Op. cit., p. 76 
cadenciadamente nos bancos em que estão sentados. Assim se divertem ${ }^{93}$.

Não há menção a este tipo de experiência nas descrições dos pousos nos trechos seguintes, entre Porto Feliz e Cuiabá. Porém, já em terras mato-grossenses, Florence registra a música praticada em uma festa de batizado pelos escravos da fazenda Jacobina, no caminho do município de Santa Maria (atual Cáceres).

Os músicos da fazenda que eram negros cativos tocaram, desde a aurora, árias debaixo das janelas da casa e passearam em bando ao redor do pátio grande. [...] Fez-se o batismo logo depois da missa, e durante a cerimônia, a música, os rojões e foguetes atroavam com extraordinário estrépito. [...] À tarde houve a ideia de dançar-se o batuque $e^{94}$.

Exceto pela menção à dança do batuque, o viajante não fornece maiores detalhes sobre a música feita pelos escravos desta que foi a mais rica fazenda da região. Não se sabe, por exemplo, quais foram os instrumentos utilizados nem o estilo executado por aqueles negros na cerimônia religiosa e nas cantorias sob as janelas do casarão. Mas o ambiente descrito nos dá uma ideia da variedade e da importância da música nesta parte remota da Paulistânia, cuja expansão se deu principalmente com a música dos camaradas, representada em algumas localidades pelo Cururu, noutras pelo Cateretê e outras tantas pelas demais modas sertanejas.

A música antiga dos sertanejos da região de Mato Grosso passa a ser conhecida como algo mais que um rastro difuso no passado, a partir dos registros etnográficos de sua prática. São diários de campo, descrições ou coletas de instrumentos, compilações de letras e melodias, etc., selecionados e revelados pela operação do etnógrafo, constituindo-se ela mesma, segundo Clifford, em uma forma própria de narrativa ${ }^{95}$. Dentre os exemplos importantes para o tema estão os cantos sertanejos cuiabanos recolhidos por Edgard Roquette-Pinto, em 1912, na ocasião em que integrou a Comissão de Linhas Telegráficas e Estratégicas de Mato Grosso ao Amazonas, liderada pelo Marechal Cândido Rondon. Em uma das expedições

\footnotetext{
${ }^{93}$ FLORENCE, Hercules. Op.cit., p. 2-4.

94 Ibidem p. 211-2.

${ }^{95}$ CLIFFORD, James. The predicament of culture: twentieth-century ethnography, literature, and art. Cambridge, MA: Harvard University Press, 1996, passim.
} 
empreendidas pela equipe, com o fim de estabelecer ligação por terra entre as cidades de Cuiabá e Porto Velho, Roquette-Pinto deparou com as numerosas tribos dos Pareci e Nambiquara que viviam a noroeste de Cuiabá, em uma extensa região entre a Chapada dos Parecis e a Serra do Norte. 0 convívio com esses povos permitiu a Roquette-Pinto reunir mais de 3.000 objetos destinados ao Museu Nacional, no Rio de Janeiro, e publicar o livro Rondônia, considerado um clássico da antropologia brasileira. Em meio a este vasto material, havia dezessete cilindros de cera gravados por Roquette-Pinto em um fonógrafo portátil movido a corda, doze deles com música dos Pareci e dois com música dos Nambiquara, constituindo os primeiros registros sonoros de música indígena feitos por um brasileiro ${ }^{96} .0$ que pouco se destaca nestas gravações é que também constavam três cantigas cuiabanas, acompanhadas por violas-de-cocho e ganzás, que foram transcritas em partitura pelo musicólogo e professor Astolfo Tavares para o livro Rondônia, juntamente com as demais músicas ${ }^{97}$. 0 cilindros de cera gravados por Roquette-Pinto foram irreversivelmente danificados pelo seu uso intenso, restando apenas uma única cópia de parte da coleção, feita em disco de 12 polegadas em 1937. Infelizmente, as cantigas cuiabanas não estão entre as nove músicas preservadas na referida cópia, mas é possível, ao menos, ouvi-las a partir das partituras transcritas por Astolfo Tavares. Com este intuito, preparamos a gravação de duas das cantigas (as que contêm letra), exibidas no CD em anexo deste estudo (faixas 4 e 5), e reproduzimos abaixo letra e música das mesmas:

\author{
Oh! dai, dai! \\ Oh! dai, dai! \\ Eu hei de morrê cantando \\ Agarrado no meu côtcho \\ Quando me vê chorando, menina, \\ É meu amô que vai s'imbora...
}

\footnotetext{
${ }^{96}$ PEREIRA, Edmundo; PACHECO, Gustavo. Texto do encarte do CD Rondônia 1912: gravações históricas de Roquette-Pinto. Rio de Janeiro: Museu Nacional/UFRJ, 2008.

97 A respeito da viola-de-cocho, mencionada na letra de uma das músicas, ROQUETTE-PINTO escreve: "Cotcho: voz cuiabana do vocábulo cocho. É uma viola feita a facão, com duas ou quatro cordas de tripa ou de fibras de palmeira, arranjadas com o material da região. Em certos desafios, o cotcho é acompanhado pelo ganzá, espécie de matraca ou reco-reco. Na sua coleção de etnografia sertaneja o Museu Nacional possui ambas. Cf. ROQUETTE-PINTO, Edgard. Op. cit., p. 344.
} 

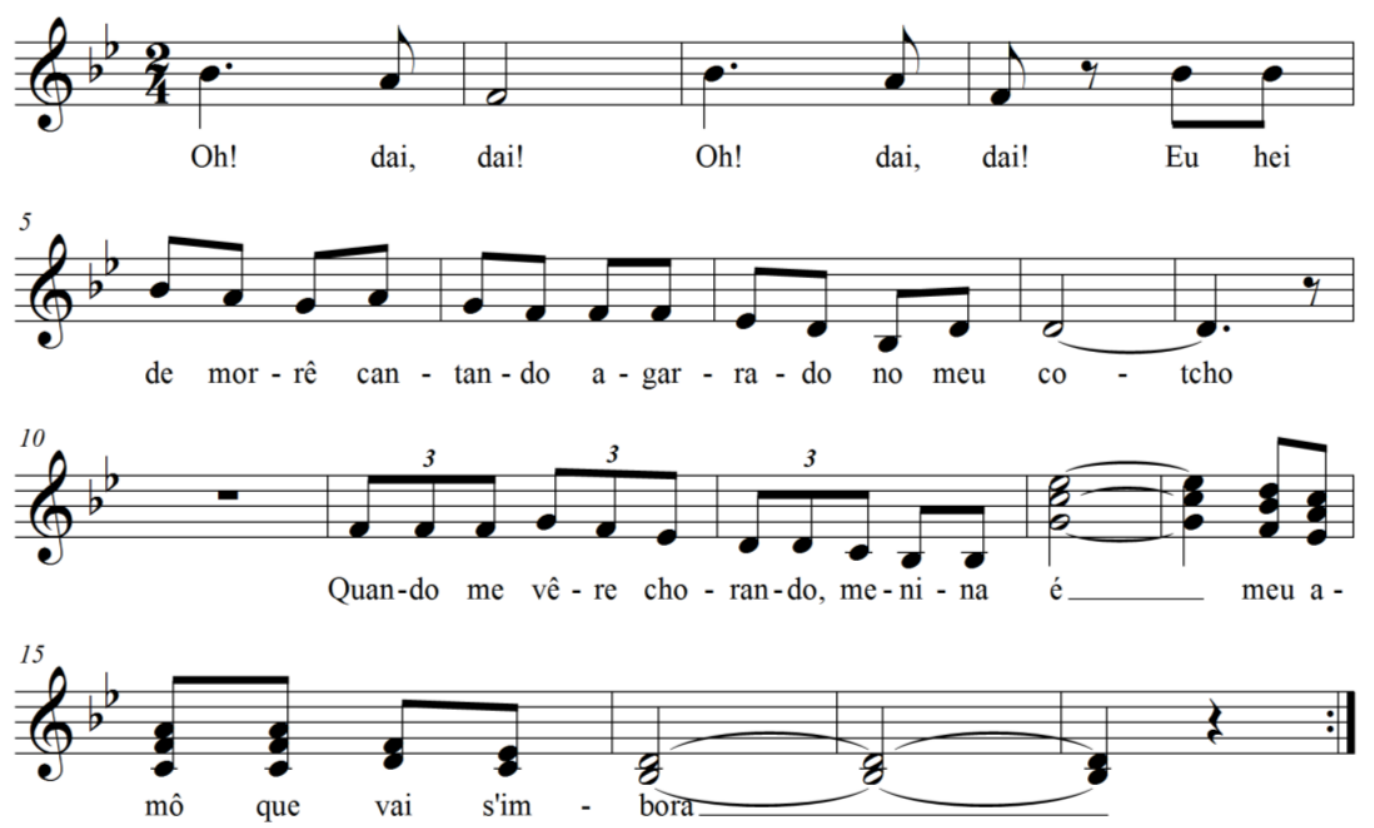

Exemplo 1: Canto dos sertanejos cuiabanos Fonograma 14.608, transcrito por Astolfo Tavares Fonte: Excursão Roquette-Pinto, 1912

Assim como na cantiga anterior, as frases melódicas curtas, em compasso binário simples, são precedidas no exemplo seguinte pelo canto silábico conhecido por baixão (oi, dai, dai... e dão, dão, dão...). Analisados isoladamente, estes dois aspectos sugerem que as duas canções podem ser tanto exemplos de Siriri quanto de Cururu. No entanto, por não serem simétricas, estas mesmas frases melódicas não permitem o canto responsorial normalmente usado no Siriri, em que o coro de dançarinos responde ao trecho cantado que é lançado em forma de pergunta pelo grupo de cantores e instrumentistas. Este aspecto nos faz, portanto, identificar ambas as canções como as mais antigas transcrições musicais de Cururu que se tem notícia. A seguir, o segundo exemplo:

Dão, dão, dão!

o que ôro não arruma,

Não tem mais arrumação...

Alecrim à beira d'água,

Mangerona d'outra banda,

É sinar de querê bem... 

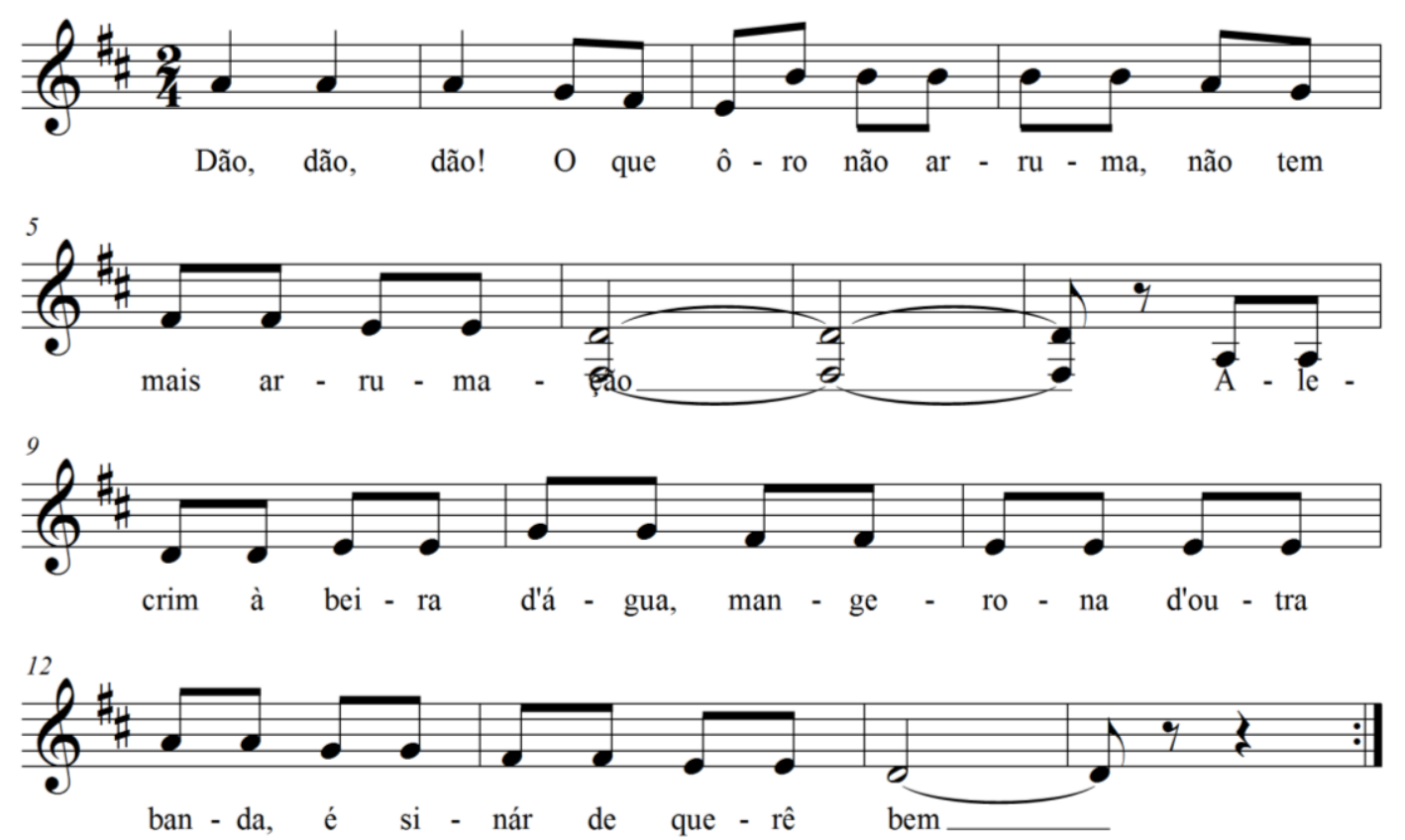

Exemplo 2: Canto dos sertanejos cuiabanos Fonograma 14.609, transcrito por Astolfo Tavares

Fonte: Excursão Roquette-Pinto, 1912

Levando-se em conta os rastros históricos aqui apresentados e considerando as hipóteses de Joaquim Ribeiro e Maynard Araújo acerca de uma cultura herdada dos bandeirantes e disseminada nas áreas mais distantes do centro-sul brasileiro, parecenos razoável supor que uma expressão musical própria dos homens pobres do lugar, como os cantos registrados por Roquette-Pinto, se fez efetivamente presente nestes meios somente a partir da sedentarização do sertanista. Ao fixar morada na beira dos rios, no entorno dos povoados, ou nas fazendas que agregavam sua força de trabalho, estes homens de condição outrora errante foram estabelecendo vínculos cada vez mais consistentes em seus novos meios, sendo a música um dos aspectos mais evidentes deste processo de territorialização das tradições. Fruto do ajustamento do colono português ao Novo Mundo (com as suas heranças ibéricas se somando a influências aborígenes), essa cultura trazida pelo sertanista paulista adquiriu em terras mato-grossenses características locais, influenciada tanto pelo contato com algumas tribos nativas quanto pela gradativa incorporação do negro ao universo rural e ribeirinho. 
Outro dado igualmente relevante neste processo foi a realidade do contingente escravo da província, que ao longo da segunda metade do século XIX se mostrou bastante próxima do cotidiano dos trabalhadores livres e pobres da região, com o dinamismo próprio da economia local levando os seus membros a estabelecer entre si laços de cooperação, amizade e família ${ }^{98}$. 0 mesmo tipo de proximidade ocorrido nos agrupamentos indígenas dos arredores de cidades como Cuiabá, onde eram igualmente constantes os conflitos e disputas entre os indivíduos que ali conviviam. É o que se pode extrair dos relatos de viagem, das posturas municipais e dos processoscrimes, que evidenciavam, além das restrições impostas pelas autoridades a tais práticas, a proximidade entre si dos cantos e danças pertencentes aos cativos e às diversas categorias de trabalhadores livres e pobres da província de Mato Grosso.

${ }^{98}$ VOLPATO, Op. cit., p. 208. 


\title{
CAPÍTULO III
}

\section{ENTRE ÍNDIOS}

\begin{abstract}
Os cunumis [...]pintados de várias cores, nusinhos, vinham com as mãos levantadas receber a benção do padre, dizendo em português, "Louvado seja Jesus Cristo." Outros saíam com uma dança d'escudos à portuguesa, fazendo muitos trocados e dançando ao som da viola, pandeiro e flauta, e juntamente representavam um breve diálogo, cantando algumas cantigas pastoris. Tudo causava devoção debaixo de tais bosques, [...] muito mais por não se esperarem tais festas de gente tão bárbara.

Pe. Fernão Cardim, Tratados da terra e gente do Brasil, 1584.
\end{abstract}

Em 1929, o escritor e musicólogo Mário de Andrade dizia haver muito pouco de "positivo" acerca da influência ameríndia na música popular que ganhou forma no Brasil do século XIX. Particularidades como a de certos sons nasais no canto, formas poéticas marcadas por refrães curtos, bem como o uso comum de maracás e outros instrumentos de percussão aborígenes, eram para o autor subsídios modestos para se formar um conhecimento técnico a respeito da contribuição do índio para a música do seu tempo ${ }^{1}$. Esse argumento era na época reforçado por Luciano Gallet, um dos primeiros estudiosos do folclore musical brasileiro, que via na facilidade com que os nativos substituíram a sua música por outra trazida pelos jesuítas uma prova de que nada de prático restara de influência indígena na cultura musical brasileira ${ }^{2}$. No entanto, a dança do Cururu significava para Mário de Andrade um dos casos evidentes de fusão "ameríndio-jesuítica" no folclore brasileiro, resultado da estratégia de

\footnotetext{
${ }^{1}$ ANDRADE, Mário de. Pequena história da música. São Paulo: Martins Editora, 1980, p. 180.

${ }^{2}$ GALLET, Luciano. O índio na música brasileira. Ensaio enviado ao Congresso Internacional de Artes Populares de Praga em 1928. In: CASCUDO. Luís da Câmara. Antologia do Folclore Brasileiro. São Paulo: Global, 2002, v. 2 p. 290.
} 
catequese adotada pelos primeiros jesuítas de permitir que os índios trouxessem suas danças para o novo culto, "deformando-lhes os textos no sentido da religião católica" 3. O autor ainda acrescentava que bastava comparar os vários registros em filme de danças praticadas por tribos não civilizadas com as coreografias do Cururu observadas nas festas religiosas dos arredores de São Paulo para se ter a certeza desta síntese ${ }^{4}$. Esta era, aliás, a tese defendida anteriormente por Couto de Magalhães, que afirmava serem duas as danças brasílicas que os jesuítas utilizaram para aquele fim: o Cateretê e o Cururu. Dentre os vários casos em que as presenciou, Magalhães contava que na capela de seu sítio de São Paulo, na estrada de Santo Amaro, essas danças e cantorias eram "rezadas" aos sábados, "pela maneira por que as ensinou o padre José de Anchieta aos Guayanás"5.

Em Mato Grosso, a associação da figura do índio ao Cururu ocorre não somente pelas possíveis origens ameríndias da dança ou pelo seu nome em si, que na língua tupi quer dizer sapo. Também participam desta soma os relatos de sua prática no seio de algumas tribos aculturadas da região, como a dos índios Guató, os Guaná e também os Bacairí, feitos por cronistas e cientistas estrangeiros que estiveram na região, em fins do século XIX e início do XX. Dentre os que trataram direta ou indiretamente desta aproximação de culturas destaca-se o etnólogo alemão Max Schmidt, que observou em 1901 o Cururu e o Siriri dançados pelos Guató da região do alto Paraguai. Além de descrever o modo como se expressavam através daquela música, Schmidt também compilou textos de canções e juntou à sua coleção dois exemplares dos instrumentos musicais confeccionados para os folguedos, uma viola-de-cocho e um caracachá, sendo o registro fotográfico destes objetos (figura 1) um dos argumentos mais usados na ligação da dança com os nativos ${ }^{6}$. Outro importante estudo é o do naturalista argentino Julio Koslowsky, que em 1894 conviveu por três semanas com os Guató daquela mesma localidade. Koslowsky não só relacionou em suas anotações alguns dos aspectos comumente associados à dança, como também

\footnotetext{
${ }^{3}$ ANDRADE, Op. cit., p. 181.

${ }^{4}$ Ibidem, p. 181.

${ }^{5}$ COUTO DE MAGALÃES, General. Anchieta, as raças e as línguas indígenas. $7^{\mathrm{a}}$ Conferência para 0 tricentenário de Anchieta. São Paulo: Typografia C. Gerke e Cia, 1897, p. 27.

${ }^{6}$ SCHMIDT, Max. Estudos de etnologia brasileira: peripécias de uma viagem entre 1900 e 1901. São Paulo: Cia. Ed. Nacional, 1942, p. 115.
} 
colheu detalhes da construção da viola pelos índios ${ }^{7}$. 0 também alemão Karl von den Steinen foi outro viajante que descreveu o que tudo indica ser a mesma prática, a julgar pela descrição dos versos cantados, dos passos da dança e o tipo de instrumento musical empregado, quando esteve em 1884 entre os Bacairí da atual região de Nobres, ao norte de Cuiabá8. Em maio de 1845, ou seja, bem antes dos relatos dos três cientistas citados, tivemos também o testemunho do naturalista e geógrafo francês Laporte de Castelnau acerca dos mesmos índios Guató do Alto Paraguai e suas violas, sendo este o mais antigo relato de viajantes usado nesta análise ${ }^{9}$.

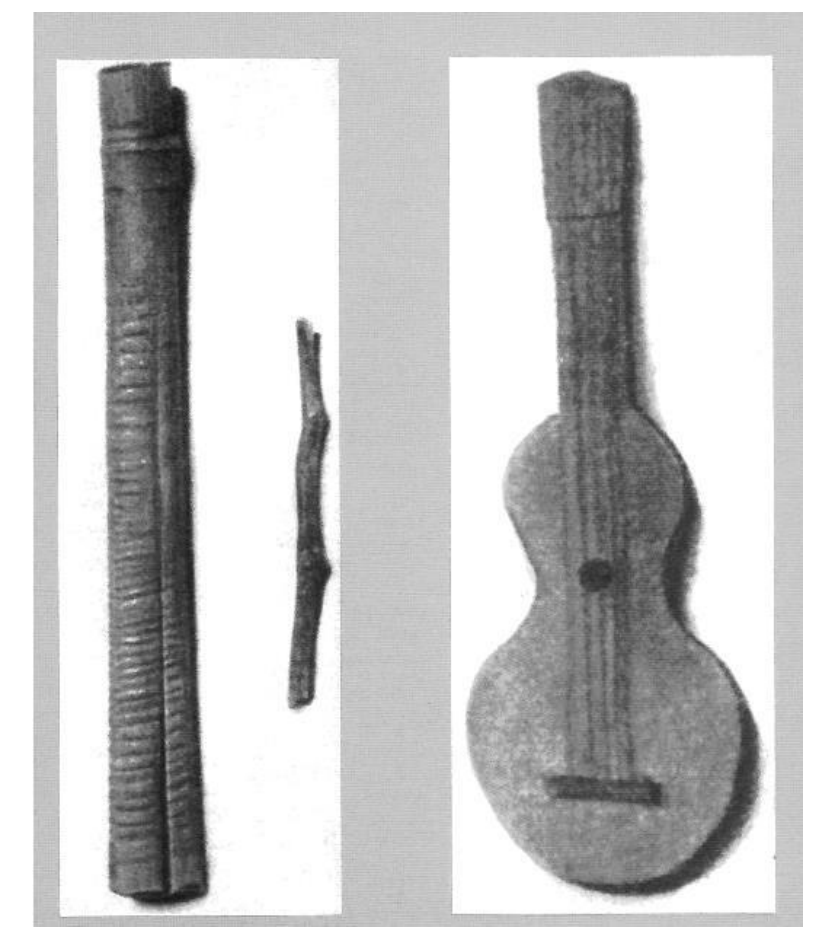

Figura 1: viola e caracachá, instrumentos de música dos Guató Fonte: Schmidt, 1942

Neste capítulo, busco articular alguns trabalhos de etnografia que fazem direta ou indiretamente menção ao Cururu entre os chamados índios "misturados" de Mato Grosso (povos, segundo Oliveira, que têm como registro uma considerável mescla de

\footnotetext{
${ }^{7}$ KOSLOWSKY, Julio. Tres semanas entre los indios Guatós: excursión efectuada en 1894. Revista del Museo de La Plata. Tomo VI, 1895, p. 231.

${ }^{8}$ STEINEN, Karl von den. O Brasil central: expedição em 1884 para a exploração do rio Xingu. São Paulo: Cia. Ed. Nacional, 1942, p. 128.

9 CASTELNAU, Francis de. Expedição às regiões centrais da América do Sul. São Paulo: Cia. Ed. Nacional, 1949, tomo II, p. 128.
} 
etnias e uma menor "distintividade cultural" 10) com outras fontes que tratam da relação desses grupos com o projeto de colonização da região. Inicio com os diários de viagem dos já citados naturalistas Castelnau, Koslowsky, Schmidt e Steinen, que são as obras que trazem a maior variedade de informações acerca da dança e dos hábitos cultivados em torno dela na região. Em seguida, abordo o contato dos índios do litoral com os missionários jesuítas que primeiro vieram ao Brasil, reconhecendo no uso da música trazida da Europa para a catequese o início de um processo de fusão de culturas que resultará em expressões até hoje presentes em algumas partes do país. Na seção seguinte, falo das missões religiosas em Mato Grosso iniciadas com a vinda dos jesuítas da América espanhola para a região, no século XVII, e com a chegada dos inacianos de origem portuguesa, por ocasião da criação da Capitania de Mato Grosso, em 1750. Também me ocupo dos relatos sobre a política de aldeamento indígena no século XIX e o deslocamento destas populações para as principais cidades da província. A abordagem do tema em uma dimensão física e temporal mais ampla se justifica em razão dos acontecimentos provenientes do contato intercultural entre índios, colonos e missionários terem ocorrido em Mato Grosso até meados do século XIX de uma forma análoga aos processos de aculturação vividos pelos índios, colonos e missionários do Brasil colonial, fazendo deste contexto um dos cenários possíveis para os sujeitos do Cururu mato-grossense.

\section{QUATRO ESTUDOS DE ETNOLOGIA}

Max Schmidt realizou sua primeira expedição científica junto aos índios da região, entre 1900 e 1901, visitando inicialmente os índios Bacairi, Naucuá, Meinacú e Camaiurá, nas áreas do alto Paranatinga e cabeceiras do Xingu. A caminho destes sítios, o jovem etnólogo permaneceu alguns dias em Rosário e assistiu pela primeira vez ao Cururu e à dança do Congo, dançados pelos negros do povoado, na festa da Imaculada Conceição. Em etapa seguinte, iniciada em setembro de 1901, Schmidt conviveu com os índios Guató do extremo oeste do Pantanal, na divisa com os estados de Mato Grosso e Mato Grosso do Sul e Bolívia. No pequeno lugarejo chamado Bracinho, um entreposto no trajeto que o levaria por canoa às aldeias próximas às

\footnotetext{
${ }^{10}$ OLIVEIRA, João Pacheco de. Uma etnologia dos "índios misturados"? Situação colonial, territorialização e fluxos culturais. Revista MANA n. 4 v.1, 1998, p. 48.
} 
baías de Guaíba e Uberaba, o alemão presenciou o Cururu entre índios e outros camaradas, em uma festa na casa do negro Reginaldo, companheiro da índia Guató Rosa. 0 local, os preparativos, as pessoas e a animação do festejo davam uma medida da importância e do significado de celebrações como aquela, sendo a embriaguez dos participantes o aspecto de maior estranheza para o autor, que registra através de seu olhar europeu e suas opiniões particulares as curiosidades daqueles primeiros contatos:

Reginaldo havia trazido de Amolar uma enorme garrafa de aguardente. Dessa maneira o cururu começou logo, dança essa que já conhecia de Rosário e que agora muito me acabrunhava, pois não poderia descansar depois das peripécias do dia. Todos fizeram círculo, João Caracará afinou a viola, alguns pratos serviram de pandeiros para as colheres e, logo depois, ouviram-se os gemidos das vozes que entoavam os versos uníssonos. 0 andar regularmente ritmado em círculo era de momento a momento interrompido por uns pulos executados pelo nosso amigo Reginaldo, que ainda procurava completar o ruído dos chamados instrumentos, batendo com as palmas das mãos nas diferentes partes do corpo propícias a isso. [...] Já havia clareado o dia e aquela gente ainda estava bebendo, de modo que quis tirar a cachaça dali e mandar que se preparassem para partir, mas notei, pelas correrias para a casa do vizinho João Procópio e seus dois irmãos e mãe, que algo de anormal ocorria. Foi hesitando que me disseram ter João Procópio e seu irmão Leonardo brigado fortemente. [...] Já havíamos perdido muito tempo com o incidente, mas como não bastasse, a índia Rosa parecia tão embriagada que não foi capaz de arrumar suas coisas. [...] Desse modo precisamos, ainda uma vez, largar depois do meio dia. Pelo menos estávamos longe de Bracinho, tendo evitado uma repetição do bailado cururu ${ }^{11}$.

Na chegada à aldeia de nome Figueira, Schmidt decide não ofertar logo de início aos moradores a aguardente que trouxera, para que pudesse dormir uma primeira noite sem ser perturbado por mais uma festa inesperada que a presença da bebida certamente iria motivar. Era para que tivesse mais tempo de conhecer os costumes da tribo. Na tarde seguinte, porém, os índios o apresentaram à chicha, bebida obtida pela fermentação da seiva da palmeira acurí, e intimaram, em troca, que a cachaça trazida pelo alemão fosse partilhada por todos,

\footnotetext{
${ }^{11}$ SCHMIDT, Estudos de etnologia brasileira. Op. cit., p. 109-10.
} 
[...] e por mais que fizesse em dar-lhes pouco, a velha mãe do Timóteo lá estava de braços dados com uma companheira, ambas deitadas à beira do rio, ora balbuciando versos do cururu, ora chorando e lamentando em altas vozes. [...] Mas é extraordinário como os índios se refazem rapidamente do estado de embriaguez. Depois do quadro descrito, adormeceram. Ao acordarem tomaram banho e então pude conversar com eles prazerosamente até que, ao anoitecer, começou o detestável cururu e suas desagradáveis consequências ${ }^{12}$.

Com todos prontos novamente para a festa, o pesquisador vivencia então sua segunda experiência com o Cururu entre os Guató. A novidade é que ele e seu novo amigo da aldeia, o garoto Mequi, de onze anos, tomam parte na celebração como músicos. No largo espaço sob as árvores, as mulheres e as crianças se acomodam em redes de dormir, enquanto os homens ao centro iniciam a dança formando um círculo.

Mequi e eu, sentados ao pé do tronco, fazíamos música, isto é, ele brandia as cordas da viola com melancólica inspiração, em acordes compassados, e eu fazia o possível para contribuir com a minha parte no "caracaxá", instrumento recém adquirido. Não foi pouca a animação produzida na festa pela minha pequena lanterna de vela de estearina que foi suspensa num galho da árvore, dominando o conjunto. Em breve os versos improvisados também estavam em bom andamento. Neles se dizia das minhas boas qualidades e, como eu era o motivo de toda alegria daquela festa ${ }^{13}$.

Mas a animação só se completou quando o alemão e o menino índio foram para o círculo dançar com os demais. A partir daí, com a bebida servida tantas vezes aos presentes, os seus efeitos passaram a dominar a cena, iniciados com os berros de uma mulher tomada de emoção pela perda dos filhos; berros estes que eram acompanhados pela também gritaria de todas as outras mulheres e mais o choro das crianças. E já perto do amanhecer as brigas entre os homens passam a fazer parte dos incidentes, com o detalhe curioso da primeira delas ter seu início motivado pelos versos improvisados da cantoria.

\footnotetext{
12 Ibidem, p. 113-14.

${ }^{13}$ Ibidem, p. 114-15.
} 
O velho Timóteo havia em verso provocado a briga, encontrando como adversário um rapazola. Assim que apareci houve ainda a possibilidade de paz. Timóteo deixou-se enganchar pelo braço, prometeu não cantar mais sob a condição de ainda dar-lhe um pequeno gole da bebida predileta e foi conduzido ao seu mosquiteiro. Houve um silêncio por algum tempo, depois ouviu-se a gritaria de uma índia que, conforme soube depois, manifestava assim o amor despertado nela pelo meu companheiro José. Esse clamor foi acompanhado durante muito tempo pelo ruidoso palavrório da mãe da índia, emudecendo, afinal, pouco a pouco. Do terreiro, porém, vinha de novo um alarido infernal, gritos agudos de medo por parte de mulheres e crianças partiam numa confusão selvagem. Antes que pudesse pular da rede e afivelar o cinto das armas, Rosa veio pedirme socorro. Dentro da escuridão só pude reconhecer o velho Timóteo nu, deitado no chão de cabeça para baixo e imóvel. 0 irmão dele, João, urrava como um animal feroz ali no mato. Tinha entrado em discussão com Timóteo, acabando por dar-lhe na cabeça com um pau. [...] Toda essa complicação surgira em virtude de João achar que Timóteo se havia embriagado muito mais que ele durante a festa ${ }^{14}$.

Koslowsky também chama a atenção em sua crônica de 1894 para os casos de agressões físicas motivadas pela bebedeira entre os Guató, como um comportamento socialmente aceitável naquela cultura, citando uma cena de luta entre tio e sobrinho que se seguiu a um momento em que todos os índios em estado de embriaguez choravam em conjunto a morte de membros da tribo ${ }^{15}$.

Para Schmidt, os alvoroços causados pelo consumo da chicha de acurí e da aguardente de cana nas celebrações de Bracinho e Figueira tinham, em parte, explicação no costume dos índios de extravasar em grupo as suas emoções e seus impulsos agressivos que, uma vez liberados pelos efeitos da bebida forte, transformavam o ambiente em pura algazarra ${ }^{16}$. Era provavelmente um estranhamento parecido ao experimentado pelos cronistas que primeiro testemunharam as cauinagens promovidas pelos Tupinambá, os festejos regados a vinho de raízes e de frutas, como o milho e a mandioca fermentados pela mastigação das mulheres das tribos, onde se decidiam alianças e guerras, choravam os mortos,

\footnotetext{
${ }^{14}$ Ibidem, p. 116-17.

${ }^{15}$ KOSLOWSKY, Op. cit., p. 237.

${ }^{16}$ Ibidem, p. 116.
} 
celebravam casamentos e, não raro, incluíam rituais de canibalismo ${ }^{17}$. Segundo Fernandes, estas formas próprias de beberagens deveriam ser um dos primeiros costumes bárbaros a se erradicar nos nativos, seja pela catequese ou pela influência do colono que iria substituir os cauins pelo hábito da aguardente de cana ${ }^{18}$. 0 consumo desenfreado desta bebida entre os nativos era, aliás, visto com igual preocupação por parte dos clérigos responsáveis pelos aldeamentos indígenas em Mato Grosso, conforme se lê no decreto de 12 de outubro de 1860, do diretor dos índios do distrito de Miranda, Frei Mariano de Bagnaia, que proibia o uso de "bebidas espirituosas" (destilados) entre os aldeados daquele distrito:

[...] em virtude das ordens do Exmo. Sr. Presidente da Província de 30 de agosto último, em conformidade com o parágrafo 24 do Art. $1^{\text {o }}$ da Lei de Regulamentos da Catequese, fica expressamente proibida a introdução de bebidas espirituosas nas Aldeias deste distrito, e as pessoas que quiserem se negociar nelas, negócios de gêneros lícitos, será sempre com a prévia e expressa permissão desta Diretoria, conforme o parágrafo 16 da referida Lei ${ }^{19}$.

\footnotetext{
${ }^{17}$ O testemunho dado no século XVI pelo jesuíta português Fernão Cardim é exemplar: “[...] alguns dias particulares em que fazem grandes festas, todas se resolvem em beber, e duram dois, três dias, em os quais não comem, mas somente bebem, e para estes beberes serem mais festejados andam alguns cantando de casa em casa, chamando e convidando quantos acham para beberem, e revezando-se continuam estes bailes e música todo o tempo dos vinhos, em o qual tempo não dormem, mas tudo se vai em beber, e de bêbados fazem muitos desmanchos, e quebram as cabeças uns aos outros, e tomam as mulheres alheias, etc." [CARDIM, Fernão.] Tratados da terra e gente do Brasil. São Paulo: Cia. Ed. Nacional, 1978 [1584]. p. 104-105. Exemplos como este são encontrados também nos períodos seguintes, como no relato do século XVIII do naturalista português Alexandre Rodrigues Ferreira: "Como ignoram a arte que têm os Europeus de ar aos licores pela fermentação uma força de embebedar, obtêm o mesmo efeito por diferentes meios. Lançam de infusão em água grandes quantidades de uns bolos chatos de mandioca (a que chamam beijus) depois de mastigados pelas velhas. A saliva excita neles uma fermentação vigorosoa, e dentro em poucos dias fica um licor de um sabor e furtum forte para a sua bebida. [...] durante o baile, mais se refina a crápula, e para não caírem de todo, em eles principiando a cambalear, encadeiam-se uns com os outros, abraçando-se pelos pescoços. Em semelhante estado é que eles cometem as maiores perfídias e impiedades; e é certo que rara é a dança que acaba sem efusão de sangue. No entanto eles só deixam de beber, em se lhes esgotando a última gota dos seus vinhos." [FERREIRA] Alexandre Rodrigues. A expedição filosófica pelas capitanias do Pará, Rio Negro, Mato Grosso e Cuiabá. Petrópolis, RJ: Kapa Editorial, 2005 [1783-1792] p. 60.

18 FERNANDES. João Azevedo. Selvagens bebedeiras: álcool, embriaguez e contatos culturais no Brasil colonial. Tese de doutorado em história. Niterói, RJ: UFF, 2004 p. 77.

${ }^{19}$ Edital do Diretor do Distrito de Índios de Miranda Frei Mariano de Bagnaia, de 12 de outubro de 1860. Acervo: APMT, Caixa 1860 A-3.
} 


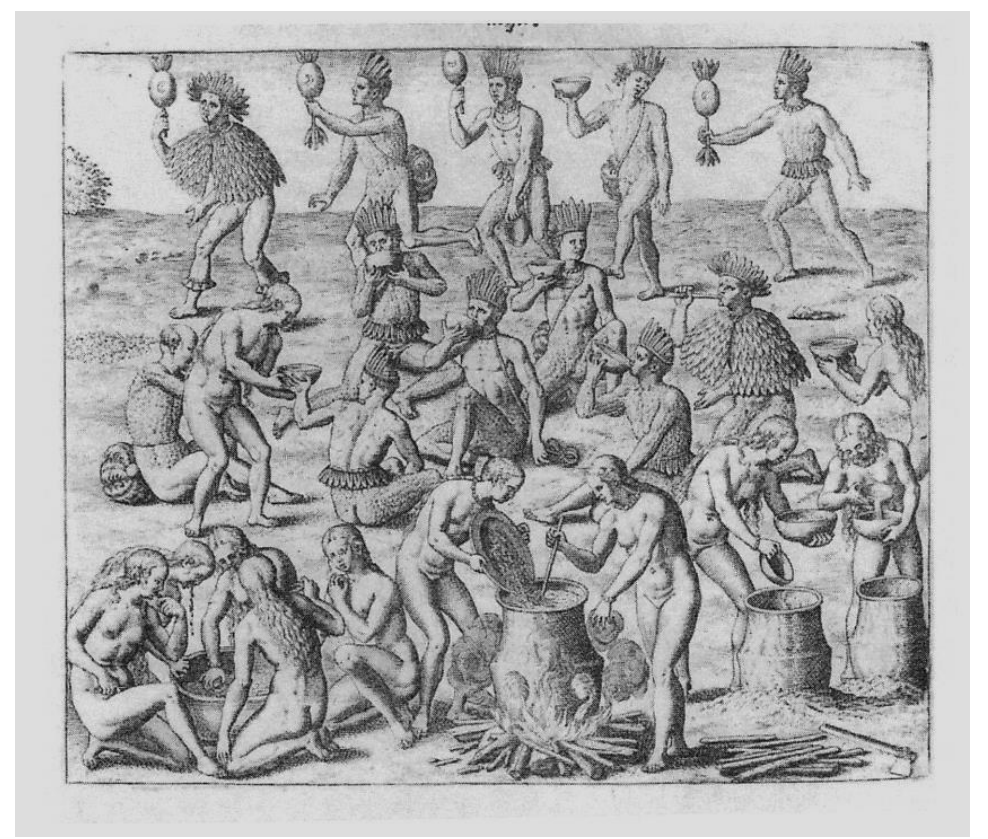

Figura 2: Theodor de Bry, Cauinagem, 1592 Fonte: Fernandes, 2004

Nos casos das brigas entre os Guató observadas por Schmidt e Koslowsky, nos hábitos de prevenção impostos aos índios aldeados da Província e mesmo nas diversas ocorrências em que as funções de Cururu nos arredores de Cuiabá eram reprimidas pelas autoridades policiais, o uso desmedido de bebidas alcoólicas que levava aquelas pessoas aos atos violentos descritos era visto pelos cronistas estrangeiros como um resquício das práticas sociais antigas dos índios, ainda não inteiramente eliminado pelo processo de aculturação e contrário aos ideais de progresso e civilização de que eram representantes.

As mesmas descrições de Max Schmidt também trazem informações importantes acerca do modo como era tocado e dançado o Cururu entre os Guató. Os instrumentos musicais são basicamente os mesmos de hoje, com destaque para o emprego de utensílios domésticos nas rodas de cantoria, a exemplo dos pratos que eram percutidos com colheres, fazendo conjunto com as violas de cocho e o ganzá (caracachá ou kerekechê). Nota-se também uma maior presença dos homens no canto e na dança, com as mulheres integrando o círculo em momentos esporádicos, descrição que coincide com a informação de Loureiro acerca da participação de homens e mulheres na época dos primeiros registros (prática que hoje é reservada 
aos homens $)^{20}$. 0 improviso nos versos é também uma característica antiga do gênero, evidenciada nas saudações ao convidado e nos desafios entre os participantes. Pelas letras das canções transcritas por Schmidt e pelo fato de não haver nenhuma menção à língua dos índios, deduz-se que o único idioma cantado no Cururu dos Guató é o português. Já a devoção aos santos católicos é um detalhe que não está presente na festa dos Guató, diferentemente do caráter religioso do Cururu praticado entre os índios Kinikináu do rio Taquari, um dos subgrupos da etnia Guaná, conforme foi observado por Döppenschmidt em região próxima àquela onde esteve Schmidt, em $1951^{21}$.

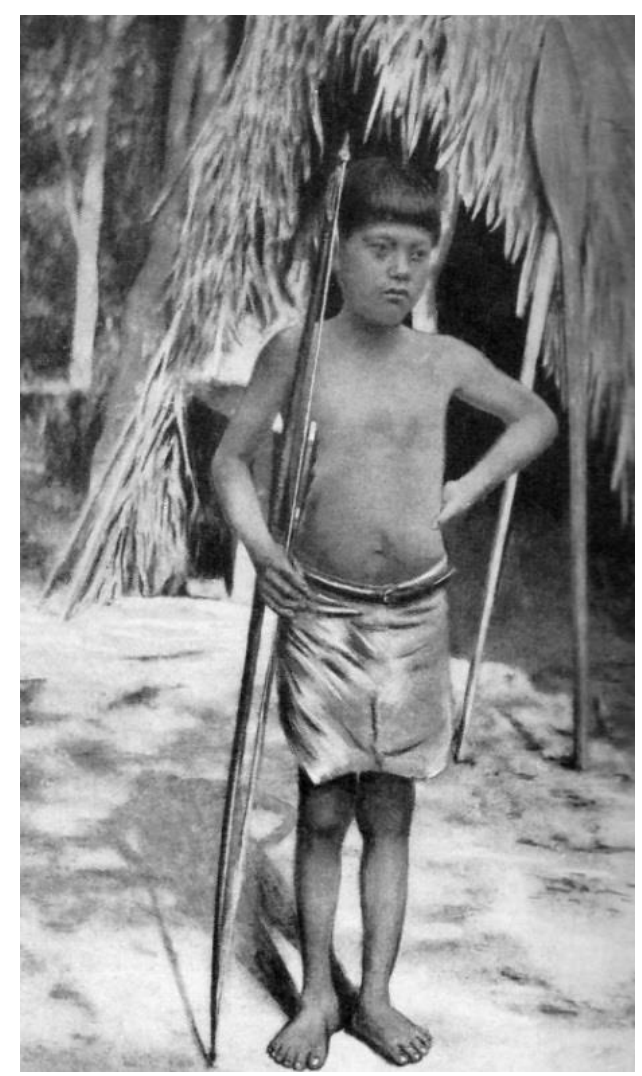

Figura 3: Mequi, o menino Guató Fonte: Schmidt, 1942

Nas duas semanas seguintes em que permaneceu nas regiões alagadas próximas à serra do Amolar, Schmidt visitou novos agrupamentos dos Guató, na beira da lagoa Uberaba, e notou em relação às comunidades anteriores alguns hábitos que

\footnotetext{
${ }^{20}$ LOUREIRO, Roberto. Cultura mato-grossense: festas de santos e outras tradições. Cuiabá: Entrelinhas, 2006 p. 73.

${ }^{21}$ DÖPPENSCHMIDT, Edmund apud CANDIDO, Antônio. Possíveis raízes indígenas de uma dança popular. In: SHADEN, Egon. Leituras de etnologia brasileira. São Paulo: Cia Ed. Nacional, 1976, p. 388.
} 
eram diferentemente afetados pela cultura do branco, como a cobertura de palhoça das habitações até o solo e o uso pelos homens de calças tecidas em algodão que ficavam presas com um fio apenas na parte frontal dos seus corpos (ver, na figura 3, a vestimenta do menino Mequi e o detalhe da habitação ao fundo) ${ }^{22}$. Presenciou nestes sítios "o inevitável cururu" em pelo menos mais quatro noites ${ }^{23}$.

Koslowsky também nos conta que foi saudado em sua visita a uma morada dos Guató pelos versos cantados do índio Joaquim Antônio e que repetiu em diversas passagens o seu improviso acompanhado à viola com as palavras "vem, rapaziada, vem ver o meu compadre!"24 (o mesmo tipo de saudação no Cururu descrito sete anos depois por Schmidt). Neste mesmo relato, outro Guató de nome Joaquim demonstra animadamente o modo como os homens da tribo caçavam as enormes onças da região, primeiro encenando a aventura com gestos e sons, depois através do seu canto acompanhado pela viola e seus passos de dança:

Después de haber templado el instrumento con rapidez, Joaquim demostró destreza en su manejo y también su talento vocal, en cuyo desempeño recordó pasajes de la reciente provocación del fingido tigre; por último se mostró digno adorador de Terpsícore, acompañando a su música y canto con saltos y pasos $[. .].]^{25}$.

A representação de animais e a exaltação das façanhas dos seus caçadores observadas na música e na dança dos Guató são também, segundo Cândido, elementos comumente encontrados nos cantos de diversas etnias indígenas, que teriam sido incorporadas a práticas hibridadas como a do Cururu. Dentre os atributos valorizados nos cantos indígenas, que também aparecem nos desafios dos cururueiros, estão o vigor físico, a eloquência e a coragem, além da habilidade do improviso na saudação e na disputa entre os participantes ${ }^{26}$. E não foram apenas estes os hábitos antigos misturados com os dos brancos que foram notados por

\footnotetext{
${ }^{22}$ SCHMIDT, Op. cit., p. 125.

${ }^{23}$ Ibidem, p. 124.

${ }^{24}$ KOSLOWSKY, Op. cit., p. 235.

25 "Depois de afinar o instrumento com rapidez, Joaquim demonstrou destreza em seu manejo e também seu talento vocal, em cujo desempenho recordou passagens da recente provocação da onça fictícia; por último, se mostrou digno adorador de Terpsícore, acompanhando sua música e seu canto com saltos e passos" [...]. Ibidem, p. 231.

${ }^{26}$ CÂNDIDO, Op. cit., p. 396.
} 
Koslowsky; os trançados de folhas em conjunto com peças de vestuário em algodão (presas ao corpo da mesma maneira observada por Schmidt), o crucifixo católico e os vasos funerários nos locais de sepultamento, uso simultâneo do português e da língua Guató no dia-a-dia além de flautas e cantos cerimoniais antigos praticados juntamente com o canto com a viola foram alguns dos costumes relatados na excursão de $1894^{27}$.

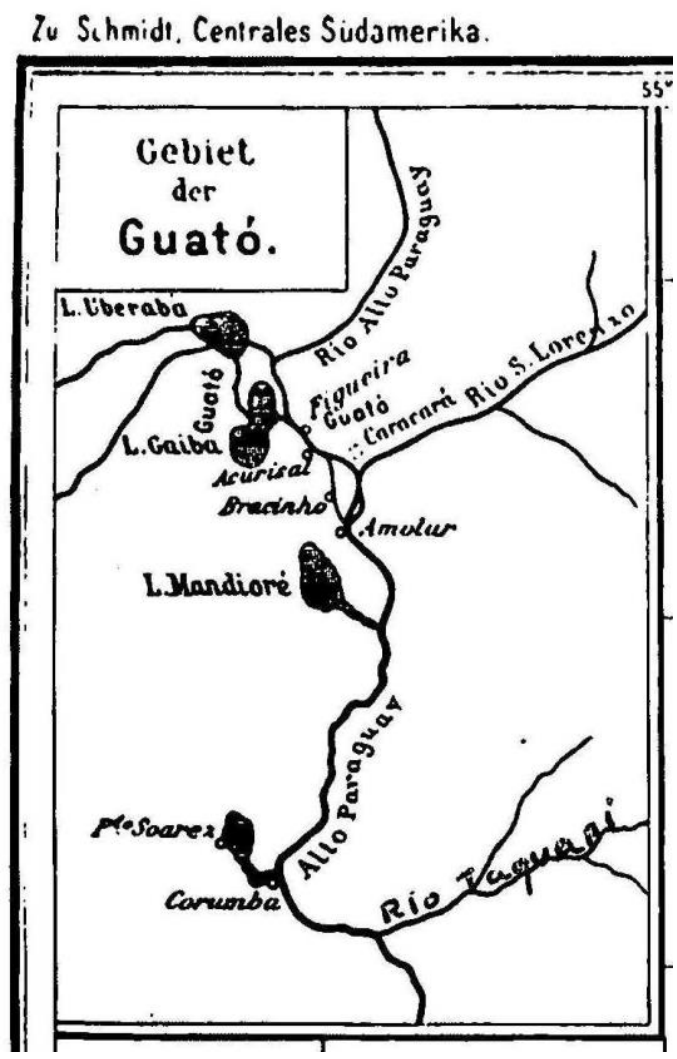

Mapa 1: região dos índios Guató, no alto Paraguai Fonte: Schmidt, 1942.

Menos rica em detalhes que a dos demais cronistas, a descrição do canto dos índios Guató feita por Francis de Castelnau é importante, sobretudo pelo seu pioneirismo. De 1843 a 1847, o geógrafo e naturalista francês percorreu longos trechos nos territórios do Brasil, Paraguai, Bolívia e Peru, registrando não apenas roteiros, cenários e características gerais dos povos visitados como também realizando estudos avançados de meteorologia, geologia, zoologia e botânica. Publicados inicialmente em Paris, entre 1850 e 1857, os relatos de Castelnau incluem o seu encontro com os Guató, na região do Alto Paraguai, em 1845, ocorrido 38 anos

\footnotetext{
${ }^{27}$ KOSLOWSKY, Op. cit., passim.
} 
antes de Koslowsky e 58 anos antes de Schmidt visitarem os mesmos lugares. Outro dado de interesse é o fato de o encontro ocorrer duas décadas antes da invasão pelas tropas paraguaias do território mato-grossense, episódio que provocou a morte de muitos índios na região. A etnia Guató despertou especial interesse em Castelnau, pelo seu físico robusto, a notável habilidade de canoeiros, o gosto destemido pela caça às onças, o uso de enormes flechas e lanças, além da sonoridade "doce" da sua língua ${ }^{28}$. A respeito dos instrumentos e da música por eles produzida, o cronista registra:

Encontramo-nos com algumas canoas de índios guatós. Dois deles traziam guitarras de sua própria fabricação e copiadas provavelmente dos civilizados. Os sons que produziam com estes instrumentos não eram mais desagradáveis do que os que conseguem os brasileiros com os seus ${ }^{29}$.

Embora Castelnau não forneça maiores detalhes da música ouvida e nem nomeie o tipo de canção ou o gênero musical ali praticados, é possível estabelecer um paralelo entre a cena descrita e os episódios similares narrados por Koslowsky e Schmidt. Nesta ocasião o viajante francês demonstra bem pouca simpatia com a música das populações pobres da região, tanto a daqueles índios quanto a dos que ele chama de "brasileiros", classificando-as como "desagradáveis" aos seus ouvidos. Um juízo que coincide com o dos demais cronistas, traduzido na imagem de uma enorme distância a ser transposta entre aquele estado, o da barbárie, e um ideal europeu de civilização $0^{30}$.

Outro exemplo a ser citado é o relato sobre os Bacairi "mansos" do Rio Novo, feito por Karl von den Steinen, quatro décadas depois, em 1884, na região do atual município mato-grossense de Nobres, ao norte de Cuiabá. Nesta aldeia, o pesquisador da Universidade de Berlim notou o que parece ser também a prática do Cururu:

Logo que anoitecia começava-se a fazer música. Os bacairís tinham aprendido, com o colono de Mato Grosso, a fazer a própria guitarra

\footnotetext{
${ }^{28}$ CASTELNAU, Op. cit., p. 321-2.

${ }^{29}$ Ibidem, p. 330.

${ }^{30}$ GALETTI, Lylia da Silva Guedes. Sertão, fronteira, Brasil: imagens de Mato Grosso no mapa da civilização. Cuiabá: Entrelinhas/EdUFMT, 2012, p. 138.
} 
que tocavam com paixão. Improvisavam pequenos "versos", eram louvores aos cães, às bananas, à lua, a uma casa e a outras coisas dessa natureza ${ }^{31}$.

O jovem Bacairí João, um dos índios cantadores que Steinen apelidara de "trovador" e que decidira acompanhar sua comitiva até as cabeceiras do Xingu, aparece em outra cena, em que "improvisa no seu violão, do qual não se separa absolutamente, mesmo quando vai banhar-se"32. Chama a atenção o fato de Steinen, assim como Castelnau e Koslowsky, não usar o termo Cururu nesta sua primeira expedição mato-grossense; ele somente o faz quatro anos depois, ao observar a dança junto aos habitantes da periferia de Cuiabá33. É possível que isto se deva ao domínio limitado da língua portuguesa e ao pouco conhecimento que o alemão possuía àquela altura da cultura musical do lugar. No entanto, isto não o impediu de registrar outro importante fato em torno da "guitarra" tocada pelo índio Bacairí, que era o de ter aprendido a confeccioná-la com o colono de Mato Grosso. Ora, um instrumento musical de feitio rústico como a viola-de-cocho, era algo perfeitamente possível de ser construído naquelas condições, ao contrário de uma "guitarra" ou um "violão" convencionais, que são os termos usados na tradução do seu livro. ${ }^{34}$

Koslowsky, ao narrar o contato feito uma década depois com o Guató Joaquim e sua viola, também forneceu ricos detalhes acerca da anatomia e da construção daquele instrumento. Descreveu o tamanho, o número de cordas e o emprego do braço e caixa de ressonância escavados em uma única peça de madeira, a exemplo das violas-de-cocho feitas atualmente:

Mi huésped se presentó, de repente, con una guitarra construida por él mismo, de cinco cuerdas como todas las guitarras que usan los Guatós y los indios Chiquitos de Bolivia. El fondo, como los costados y el mango de estas guitarras, son hechos de uno solo trozo de madera, y solo la cubierta, sobre la que se apoyan las cuerdas, está pegada sobre la caja con resina del árbol "yatubá", cuyos frutos proporcionan también alimento. Las tales guitarras miden la mitad del tamaño de

\footnotetext{
${ }^{31}$ STEINEN, O Brasil central, Op. cit., p. 128.

${ }^{32}$ Ibidem. 158.

33 Idem. Entre os aborígenes do Brasil central. São Paulo: Dep. De Cultura, 1940, p. 117.

34 Termos traduzidos do alemão "Guitarren" e "Violine". Cf. STEINEN, Karl von den. Duch Central-Brasilien: expedition zur erforschung des Schingú in jahre 1884. Leipzig: F. A. Borockhaus, 1886, p. 105 e 131.
} 
las españolas, no fabricándolas nunca más grandes. [...] Después de haber cantado y bailado hasta el cansancio, este indio no tuvo dificultad en darme su guitarra en cambio de algunos objetos ${ }^{35}$.

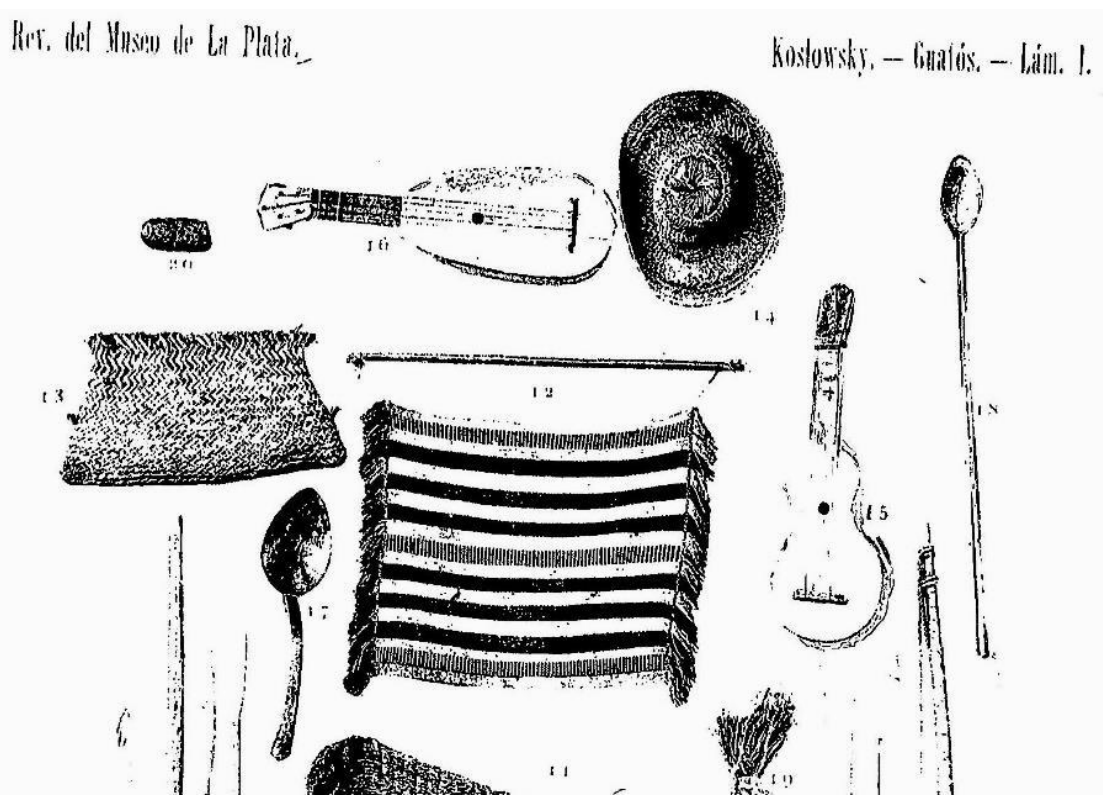

Figura 4: objetos etnológicos dos Guató Fonte: Koslowsky, 1894.

Também vale destacar o que Couto Magalhães menciona em mais de uma ocasião, a existência de violas há muito incorporadas pelos índios, que eles próprios confeccionavam e as nomeavam em sua própria língua: “[...] tendo assistido muitas vezes a estas festas e danças ao som da viola, que era instrumento indígena de três cordas de tripa, a que eles chamavam guarará-pewa" [...] ${ }^{36}$. Florence é outro cronista que relata o mesmo costume entre os tapuios (apelido dado aos índios aculturados) que viviam nos arredores de Santarém de forma modesta, contentando-se com muito

\footnotetext{
35 "Meu anfitrião se apresentou, de repente, com uma viola de cinco cordas, construída por ele mesmo, como todas as violas que usam os Guatós e os índios Chiquitos da Bolívia. O fundo, as laterais e o braço, são feitos de uma única peça de madeira, e somente o tampo sobre o qual se apoiam as cordas está pregado sobre a caixa com resina da árvore do jatobá, cujos frutos também são alimento. Estas violas têm a metade do tamanho das guitarras espanholas, nunca sendo fabricadas em maior tamanho. [...] Depois de haver cantado e bailado até se cansar, não foi difícil para este índio dar-me sua viola em troca de alguns objetos." KOSLOWSKY, Op. cit., p. 231.

${ }^{36}$ COUTO DE MAGALHÃES, Op. cit., 1942, p. 23 (grifo meu).
} 
pouco: "uma choupana, umas plantaçõeszinhas, algumas galinhas, roupa pouca de algodão, uma viola, eis o que desejam" 37.

Além do canto acompanhado pela viola do colono, outro episódio a ser destacado no contato de Steinen com os Bacairí de Mato Grosso é o da noite em que o etnólogo alemão testemunha a música tocada pelos índios em "seus originais instrumentos indígenas [...] guardados na floresta" ${ }^{38}$. Steinen descreve flautas de variados tamanhos com os quais os índios executavam uma melodia simples, "composta de cinco tons", que o impressionou a ponto de dizer que possuía "algo de suave ao mesmo tempo de terrível"39. A sua visão de mundo era, segundo Galetti, típica do cientificismo eurocêntrico de fins do século XIX e inícios do $\mathrm{XX}^{40}$, o que não impede de identificamos naquela narrativa a percepção de um entrelaçamento de culturas que se revela mais complexo que a simples imagem de um contínuo processo de suplantação de uma cultura dominada por outra dominante. 0 caso de alguns Bacairí aculturados que se vestiam com calças de algodão e cantavam acompanhados da viola, mas que também se "despiam", se adornavam e se reuniam para celebrar rituais como faziam os "antigos" 41 indicava, ao menos, o mesmo tipo de negociação estabelecida no processo geral de aculturação experimentado na época da colonização portuguesa, que possibilitou

[...] a elaboração de discursos que justificaram o domínio europeu, mas que, por outro lado, também permitiu aos índios montar esferas de autonomia espiritual que foram fundamentais para o seu próprio esforço de resistência e adaptação ao torvelinho da expansão europeia ${ }^{42}$.

Posteriormente, em 1901 e 1926, seu discípulo Max Schmidt visitou as mesmas aldeias Bacairi da região de Nobres e em nenhuma das duas ocasiões encontrou violeiros e cantadores que haviam aprendido a arte da viola com o

\footnotetext{
${ }^{37}$ FLORENCE, Hercules. Viagem fluvial do Tietê ao Amazonas de 1825 a 1829. Brasília: Senado Federal, 2007, p. 264 (grifo meu).

${ }^{38}$ STEINEN, O Brasil central. Op. cit., p. 128.

${ }^{39}$ Ibidem p. 129.

${ }^{40}$ GALETTI, Op. cit., p. 125.

${ }^{41}$ STEINEN, O Brasil central. Op. cit., p. 124.

${ }^{42}$ FERNANDES, Op. cit., p. 3.
} 
colono $^{43}$, fato que nos leva, por sua vez, a relativizar a identificação de uma determinada prática adotada por indivíduos ou grupos como sendo a de traços já incorporados àquela cultura. Também nas ocasiões seguintes em que viajou à região dos Guató, em 1910 e 1928, Schmidt não fez menção alguma ao Cururu, direcionando suas pesquisas para a coleta arqueológica e o levantamento de dados sobre a língua dos índios ${ }^{44}$. É possível que o cultivo da dança tenha deixado de ocupar o espaço que tinha anteriormente naquela sociedade, em especial pela diminuição da população e sua dispersão provocada pelo avanço dos fazendeiros em suas terras.

Os ecos desta larga prática foram também abordados no documentário “500 Almas”, filmado em 2005 por Joel Pizzinni. Em uma das cenas vemos os índios José e Veridiano, já falecidos, dedilhando uma viola-de-cocho e demonstrando no esculpir da madeira e no preparo da cola (feita da poca, a bexiga natatória do peixe) o modo como confeccionavam aquele instrumento ${ }^{45}$. Pelas notícias que obtive em 2012 pelo professor e antropólogo Jorge Eremites de Oliveira acerca das pessoas retratadas no filme, apenas os índios Vicente e Zequinha viviam ainda no rio São Lourenço e na ilha Ínsua e conheciam a arte da viola-de-cocho ${ }^{46}$. Isto também demonstra um declínio do Cururu entre os Guató, se compararmos ao que foi observado desde Castelnau, em 1845, até Max Schmidt, em 1901. O esforço iniciado em 1977 pela FUNAI de reunir os membros remanescentes em seus territórios tradicionais e reorganizar os elementos mais antigos de sua cultura, através do ensino regular da língua aos mais jovens, o apoio ao artesanato dos trançados, da madeira e da cerâmica, bem como a garantia de seus meios tradicionais de subsistência, poderá contribuir para permanência da tradição do Cururu se a mesma ainda fizer parte da sua atual realidade ${ }^{47}$.

\footnotetext{
${ }^{43}$ SCHMIDT. Max. Resultados a minha expedição bienal a Mato Grosso, de setembro de 1926 a agosto de 1938. Boletim do Museu Nacional. Rio de Janeiro: Imprensa Nacional, XIV - XVII, 1942, p. 242.

44 _. Resultados de mi tercera expedición a los Guatos efectuada en el año de 1928. Revista de la Sociedad Científica del Paraguay, Asunción, 5(6), 1942, p. 41-75. Ver também OLIVEIRA, Jorge Eremites de. Os primeiros passos em direção a uma arqueologia pantaneira: de Max Schmidt e Branka Susnik a outras interpretações sobre os povos indígenas nas terras baixas do Pantanal. Revista de Arqueologia. São Paulo: SAB, v. 20, 2007, p. 90.

45500 Almas (2005). Direção de Joel Pizzini Filho. São Paulo: Grifa Filmes. DVD (109 min.), son. color.

${ }^{46}$ OLIVEIRA, Jorge Eremites de. Guató. Mensagem recebida por <eremites@ufgd.edu.br> 26/04/2012.

${ }^{47}$ Desde o século XVI a presença dos Guató é noticiada em toda a planície alagada do Alto Paraguai, onde vivem em pequenos núcleos familiares. A expansão da atividade pecuária em fins da década de 1940 levou a um radical processo de expulsão de seus territórios, com muitos se mudando para a periferia de cidades como Corumbá, Aquidauana, Cáceres e Poconé. Isso fez com que fossem considerados extintos na década
} 


\section{A MÚSICA DOS JESUÍTAS NO BRASIL COLONIAL}

As práticas anotadas por Castelnau, Steinen, Schmidt, Döppenschmidt e Koslowsky podem, como dissemos, ser relacionadas às primeiras experiências que tiveram os índios do Brasil, nos primeiros contatos com os jesuítas. Isso porque, desde a sua chegada em 1549, os inacianos liderados por Manuel da Nóbrega perceberam a enorme curiosidade do gentio pela música que traziam e se valeram da novidade como instrumento de aproximação para a catequese. Além de adaptar seus cantos religiosos à língua geral nengatu e ensinar os meninos curumins a tocar flautas, rabecas e violas, os jesuítas permitiram que os índios trouxessem para o contexto de algumas das celebrações católicas suas próprias danças e cantos, o que significou provavelmente o primeiro importante fenômeno de hibridismo de culturas no Brasil. Entendiam os padres que a tolerância aos costumes nativos nos cultos que eles ensinavam era um recurso provisório, porém necessário ao trabalho de conversão, mesmo quando não contavam com a aprovação dos seus superiores ${ }^{48}$. É o que Nóbrega testemunha, em 1552, a respeito das críticas do Bispo da Bahia ao modo como os meninos trazidos do Colégio dos Órfãos de Lisboa ${ }^{49}$ eram colocados em contato com as tribos:

Os meninos desta casa costumavam cantar, pelo mesmo tom dos Índios, e com seus instrumentos, cantigas em louvor de Nosso Senhor, com que se muito atraíam os corações dos índios; e assim alguns meninos da terra traziam o cabelo cortado à maneira dos Índios, que têm muito pouca diferença do nosso costume, e faziam tudo para a todos ganharem. Estranhou-o muito o Bispo, e na primeira pregação falou nos costumes dos gentios muito largo, por donde todo o auditório o tomar por isso e foi assim, porque a mim o repreendeu mui asperamente, nem aproveitou escusar-me que não

\footnotetext{
de 1950 pelo Serviço de Proteção aos Índios e não recebessem qualquer tipo de apoio dos governos. A situação mudou a partir de 1976, quando missionários indigenistas de Corumbá começaram a identificar membros da etnia dispersos em várias localidades, passando-se desde então a trabalhar pelo seu reconhecimento étnico. Cf. SILVA, Giovani José da. Enciclopédia dos povos indígenas. $<$ http://pib.socioambiental.org/pt/povo/guato/print>. Acesso em: 07/08/2013.

${ }^{48}$ HOLLER, Marcos. Os jesuítas e a música no Brasil colonial. Campinas, SP: Unicamp, 2010, p. 159.

${ }^{49}$ A fundação do primeiro colégio da ordem em solo brasileiro, o Colégio dos Meninos de Jesus da Bahia, se dá com a chegada em 1550 de sete dos meninos órfãos acolhidos no colégio de Lisboa. Cf. HOLLER, Op. cit., p. 51.
} 
eram ritos nem costumes dedicados a ídolos, nem que prejudicasse a fé católica ${ }^{50}$.

Estes meninos continuariam a ser educados para a ordenação no sacerdócio, além de convocados a atuar como chamariz dos índios normalmente arredios ao primeiro contato. Nóbrega indica em outra carta de 1552 que as mesmas tarefas eram também cumpridas pelos curumins: "Eu tinha dois meninos da terra para mandar a V. R., os quais serão muito para a Companhia. Sabem bem ler e escrever e cantar, e são aqui pregadores, e não há mais que aprender" ${ }^{51}$. Vê-se como era importante o uso da música na formação do novo rebanho, mesmo não tendo sido ela uma prática recomendada pelos superiores da Companhia, posto que eram vários os regulamentos determinando que os padres se ocupassem dos "exercícios espirituais" e não de atividades que os distraíssem ${ }^{52}$.

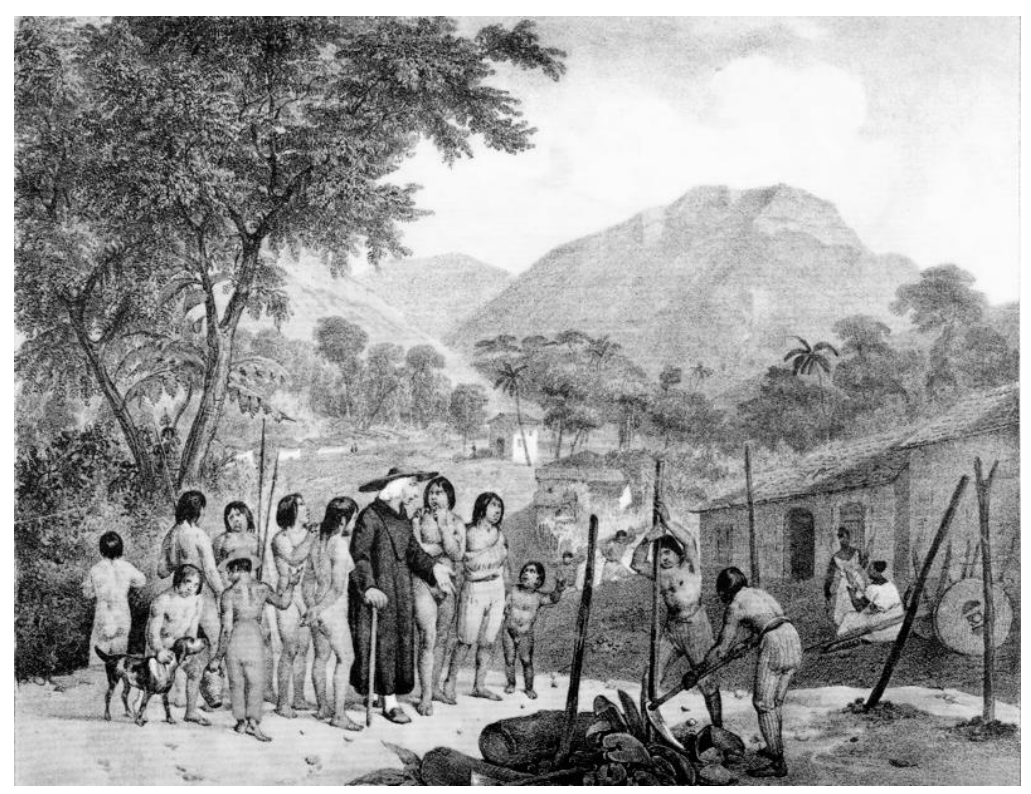

Figura 4: Rugendas, Aldeia de Tapúyas Fonte: Costa, 1995

Do momento da sua chegada ao Brasil até a assinatura do decreto real de 1759 que determinou o sequestro dos bens e a expulsão imediata de todos os seus membros, a ordem manteve perto de duas centenas de estabelecimentos, entre

\footnotetext{
${ }^{50}$ Carta de Nóbrega ao padre Simão Rodrigues, de julho de 1552. In: LEITE, Serafim. Novas cartas jesuíticas. São Paulo: Cia. Ed. Nacional, 1940, p.32.

${ }^{51}$ Carta de Nóbrega ao padre Simão Rodrigues, de junho de 1552. In: HOLLER, Op. cit., p. 161.

${ }^{52}$ HOLLER, Op. cit., p. 138-141.
} 
colégios, seminários, casas, aldeias e fazendas, sendo a proximidade destes estabelecimentos com os aglomerados urbanos o principal diferencial da empresa jesuítica no Brasil colonial, quando comparada ao lado espanhol. Ao priorizar sua atuação em áreas distantes das cidades, o sistema missionário na América espanhola fazia com que os índios reunidos nesses núcleos se dedicassem integralmente ao culto e aos trabalhos da aldeia. Um dos resultados deste maior isolamento foi justamente a emergência de uma prática musical mais fiel à tradição europeia, tendo a descoberta de instrumentos, partituras musicais e documentos escritos demonstrado tal particularidade no modelo ibérico ${ }^{53}$. Mas, se a experiência brasileira se caracterizava pela inconstância gerada pela proximidade dos povoados e o regime de repartição do trabalho com o colono, eram estas mesmas dificuldades que permitiam uma negociação mais balanceada entre os valores autóctones e a cultura trazida de fora. Negociação em que, "de um lado, os grupos indígenas incluíam na sua vida religiosa elementos tomados ao cristianismo; de outro, a catequese assumia certos compromissos com a cultura local" 54 .

No interior das igrejas a música deveria seguir o repertório universal prescrito por Roma, mas as condições em que eram desenvolvidos os trabalhos evangelizadores faziam com que práticas como ladainhas, procissões e folias se fizessem mais presentes que os ofícios e as missas. Estas celebrações ao ar livre, que foram incentivadas pelos jesuítas, seus grandes cultores no período colonial, tinham o propósito de fazer com que tomassem o lugar dos festejos nativos, como única forma de manifestação lúdica possível dentro da rotina da catequese ${ }^{55}$. Para isso, os missionários inicialmente se apropriaram da língua e das danças dos índios, para que, atuando em seus mundos, a conversão se fizesse com mais facilidade. A ironia dos fatos fez com que o caráter, ao mesmo tempo, religioso-educativo e recreativo daquelas procissões se impregnasse de elementos das culturas dos dois mundos, dando forma a muitas das festas religiosas que conhecemos hoje. E foi, portanto, em decorrência deste menor rigor no trato de suas obrigações como catequistas que os

\footnotetext{
${ }^{53}$ Como exemplo da maior importância dada à música pelas reduções espanholas, os inventários mostram um número aproximado de 1.700 instrumentos musicais pertencentes aos seus estabelecimentos, ao passo que as relações de bens das missões portuguesas mostram um total de 56 instrumentos. Cf. HOLLER, Op. cit., p. 207.

${ }^{54}$ CÂNDIDO, Op. cit., p. 391.

${ }^{55}$ TINHORÃO, José Ramos. As festas no Brasil colonial. São Paulo: Editora 34, 2000, p. 26.
} 
primeiros jesuítas contribuíram para a emergência de práticas sincréticas de devoção, repletas de superstições e ritos notadamente carregados de acentos ameríndios, que se fazem presentes ainda hoje nas festas religiosas dos lugares brasileiros onde permanecem aspectos da vida rústica colonial ${ }^{56}$.

\section{AS MISSÕES JESUÍTICAS EM MATO GROSSO}

A presença dos padres da Companhia de Jesus no vasto território de Mato Grosso foi uma iniciativa dos lados espanhol e português. Ambos assumiram, nos séculos XVII e XVIII, respectivamente, a difícil missão de evangelizar o gentio e defender os interesses de suas coroas naquele território que era alvo de disputa pelos dois lados. Os obstáculos impostos por condições naturais adversas e um número reduzidíssimo de missionários, que se somavam a diversos conflitos de interesses entre colonos, governos e os próprios clérigos, fizeram com que a empresa inaciana tivesse em Mato Grosso uma existência curta, porém, com efeitos práticos no modo como se desenvolveu posteriormente a política de aldeamento dos índios. E mesmo não havendo neste período referência a práticas musicais como as relatadas pela Companhia em outras partes do Brasil ou nas mais organizadas reduções (ou missões) castelhanas, é possível relacionar a história deste período ao cenário de práticas culturais que se delineará futuramente.

Os levantamentos acerca dos estabelecimentos da ordem na América portuguesa feitos à época da expulsão promovida pelo Marquês de Pombal relacionam apenas duas aldeias jesuíticas no governo de Cuiabá57. Embora não estejam especificados nomes ou localidades, estes dados podem ser atribuídos ao número de missionários que inauguraram a presença inaciana portuguesa na região. Segundo a historiografia local, os padres Estêvão de Castro e Agostinho Lourenço fizeram parte da comitiva do governo nomeado para a recém-criada Capitania de

\footnotetext{
56 CASTAGNA, Paulo. A música como instrumento de catequese no Brasil dos séculos XVI e XVII. D.O. Leitura. São Paulo, ano 12, n.143, 1994, p. 6.

57 Relação a partir das seguintes fontes: "Catálogo das residências, colégios, seminários e missões nas províncias do Brasil em 1749"; "Relação por capitania do número de colégios, seminários casas, missões e residências da Companhia de Jesus no Brasil em 1750"; História da Companhia de Jesus na extinta província do maranhão e Grão Pará, do padre José de Morais (1759); História da Companhia de Jesus, de Serafim Leite (1938-1949). In: HOLLER, Marcos Tadeu. Uma história de cantares de Sion na terra dos brasis: a música na atuação dos jesuítas na América Portuguesa (1549-1759). Tese de doutorado em musicologia. Campinas, SP: UNICAMP, 2006, p. 68.
} 
Cuiabá, tendo o primeiro se encarregado da fundação, em 1751, de uma missão no atual município de Chapada dos Guimarães e o segundo acompanhado o Governador e Capitão-General Dom Antônio Rolim de Moura na construção da capital, Vila Bela da Santíssima Trindade, na região do rio Guaporé58. Em seu relato de viagem, o fidalgo português descreve o embarque no povoado paulista de Porto Feliz dos dois missionários citados e observa, ao longo do trajeto monçoneiro de mais de seis meses que começava pelo rio Tietê rumo às minas de Cuiabá, a presença dos jesuítas “castelhanos, entre Rio Grande e Paraguai, onde eles têm infinitas missões”59.

Apesar do testemunho de Rolim de Moura acerca das "infinitas missões" que se irradiaram a partir de Assunção, as investidas jesuíticas do lado espanhol também não prosperaram por muito tempo na parte setentrional da bacia do rio Paraguai. Fundadas em 1631, nas proximidades do atual município de Aquidauana e destruídas pelos bandeirantes luso-paulistas por volta de 1647 , as missões do Itatim tiveram seu funcionamento condicionado por uma geografia pouco conhecida e uma natureza inóspita que chegava a privar os missionários das condições mínimas de sobrevivência ${ }^{60}$. Dificuldades ocorriam também em função dos bloqueios impostos pelas numerosas tribos da região do Chaco, em especial os bravios Guaicuru e Paiaguá, que frustraram a intenção dos missionários espanhóis de interligar as missões paraguaias do Itatim com as de Mojos e Chiquitos. Isto fez com que os jesuítas castelhanos não tivessem êxito em estabelecer na região de Mato Grosso o mesmo modelo sofisticado de redução dos índios experimentado nos atuais territórios do Paraguai, Bolívia e sul do Brasil. Sendo assim, a música não poderia florescer nestas comunidades com a mesma pujança registrada nas principais missões espanholas. No entanto, é sabido que nestes estabelecimentos vizinhos eram ensinados diversos ofícios, incluindo a música, a pintura, estatuária, carpintaria e a

\footnotetext{
58 SIQUEIRA. Elisabeth Madureira. História de Mato Grosso: da ancestralidade aos dias atuais. Cuiabá: Entrelinhas, 2002, p. 42.

${ }^{59}$ Relação da viagem que fez o Conde de Azambuja, D. Antonio Rolim, da Cidade de S. Paulo para a Villa de Cuyabá, em 1751. Revista do Instituto Histórico e Geográfico Brasileiro. Rio de Janeiro: L. P. Costa, n. 25 tomo VII, 1815, p. 473. Estas missões eram provavelmente as do Guairá que foram obrigadas, pelos ataques dos bandeirantes, a se mudar para o lado oeste do rio Paraná. Cf. NETO, Miranda. A utopia possível: missões jesuíticas em Guairá, Itatim e Tape, 1609-1767, e seu suporte econômico-ecológico. Brasília: FUNAG, 2012, p. 30.

${ }^{60}$ GADELHA, Regina Maria A. F. As missões jesuíticas do Itatim: um estudo das estruturas socioeconômicas coloniais do Paraguai, séculos XVI e XVII. Rio de Janeiro: Paz e Terra, 1980, p. 191.
} 
luteria. Com isso, é possível que instrumentos como o representado na escultura em madeira, da figura 5, tenham chegado à região das missões do Itatim pelas mãos dos mesmos jesuítas, sendo esta suposição ainda mais pertinente se lembrarmos que este é o mesmo território onde Schmidt presenciou o Cururu entre os Guató (ver mapas 1 e 2).

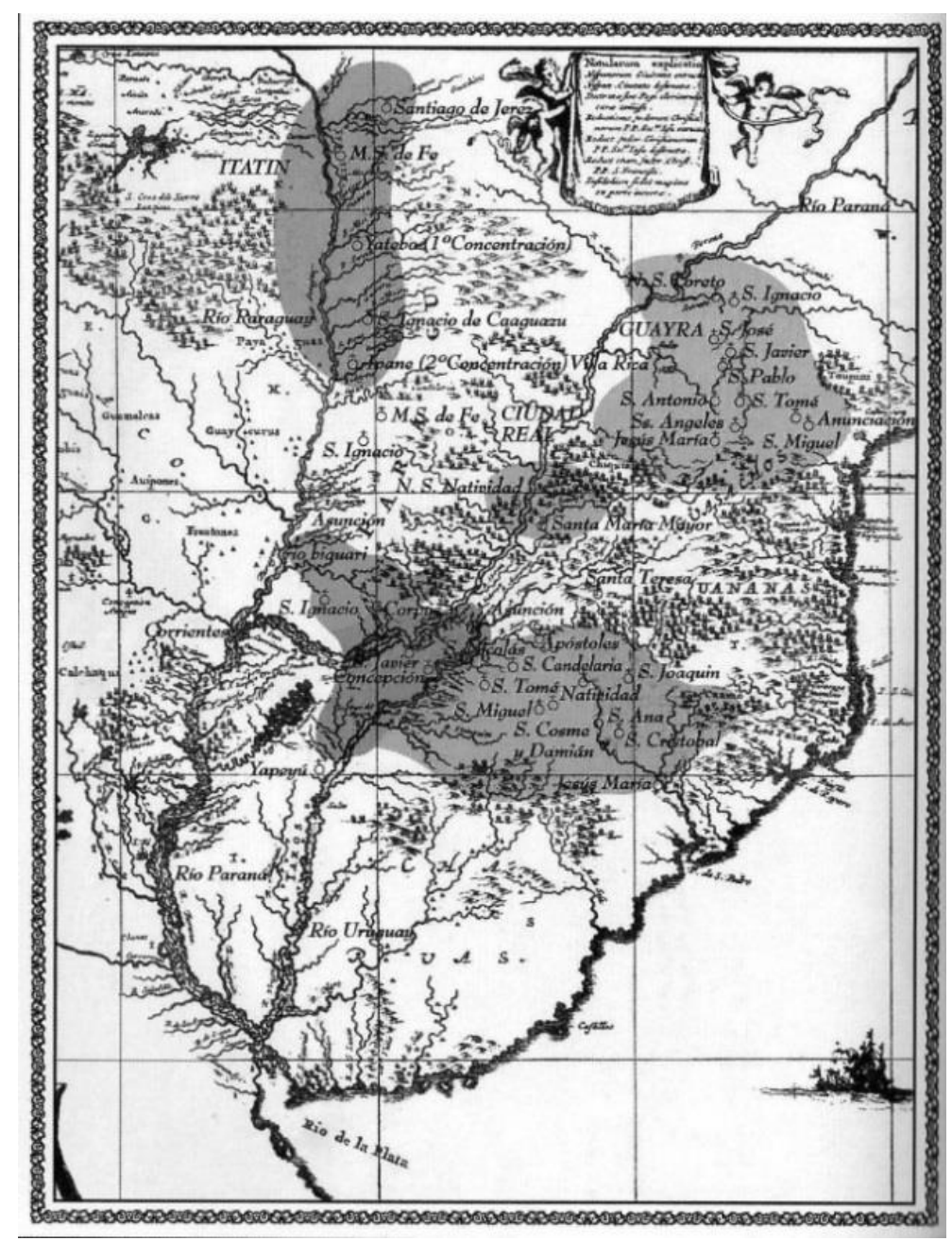

Mapa 2: Missões irradiadas de Assunção, séc. XVII Fonte: Heguy, 2009

Ainda em relação à música ensinada pelos missionários castelhanos, Couto de Magalhães nos traz, em sua conferência proferida em 1897, informações que identificam na herança destes missionários o mesmo tipo de contribuição musical que os jesuítas de origem portuguesa deixaram junto aos índios no Brasil colonial: 
Creio que os jesuítas da República Argentina, do Paraguai e da Bolívia adaptaram também os cantos e danças do cateretê para festas religiosas entre os índios, pelo menos as de Santa Cruz, porque assisti em Corrientes e Assunção celebradas com ele, como se faz até hoje nos sítios e povoados anteriores ${ }^{61}$.

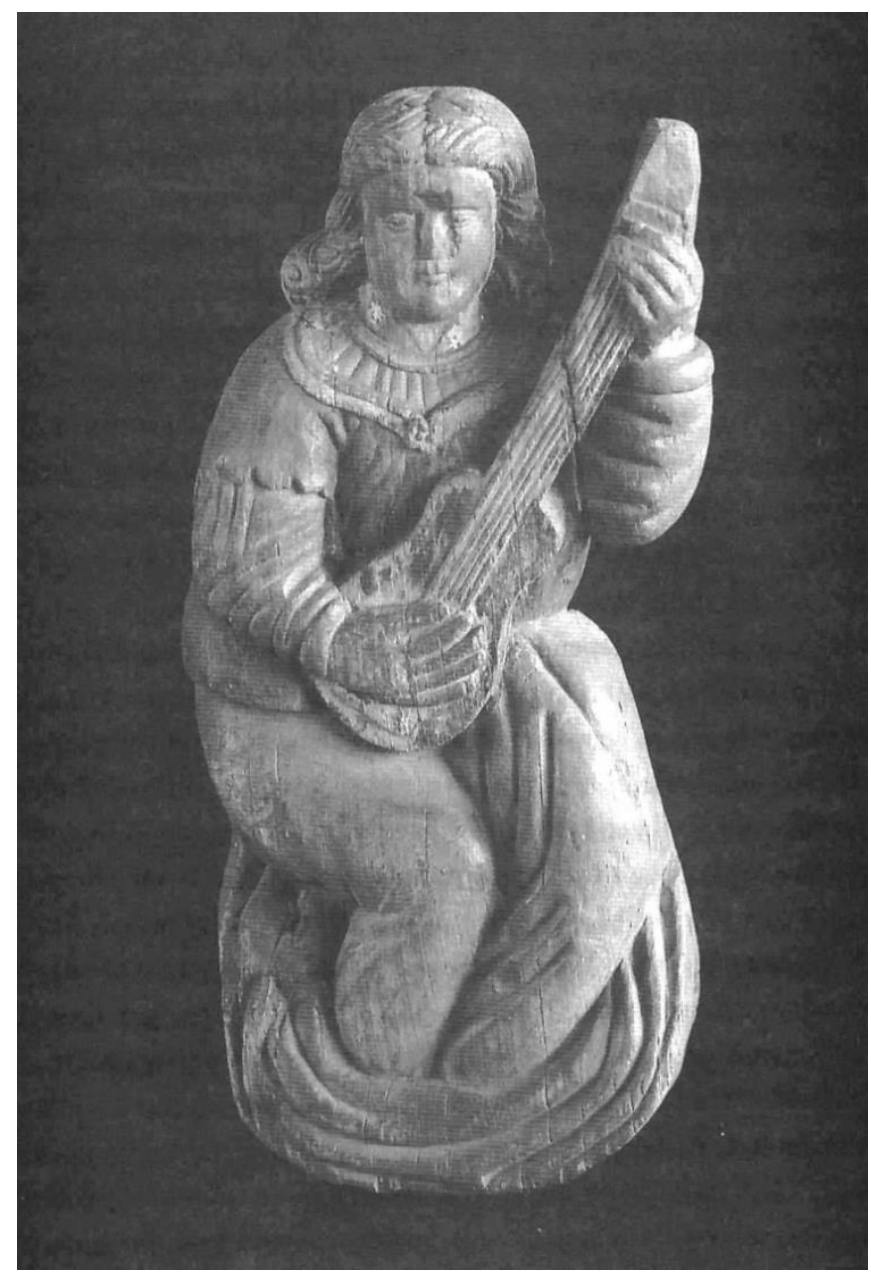

Figura 5: Anjo músico - madeira policromada (Sete Povos das Missões) Fonte: Assunção, 2009

É sugestiva a ideia de terem partido de regiões da Argentina, Paraguai e Bolívia expressões musicais análogas, que se intercomunicaram com outras provenientes das regiões mais próximas do litoral brasileiro, mesmo sendo possível haver o político e folclorista brasileiro se enganado quanto ao emprego do termo cateretê para as manifestações que presenciara nestes países hispânicos. Isto porque há uma série de indícios que apontam para uma maior troca de influências entre a música cultivada pelas camadas baixas das Américas portuguesa e espanhola, a começar pelos aspectos

${ }^{61}$ COUTO DE MAGALHÃES, Op. cit., p. 30 (grifo meu). 
musicais, formas de expressão e designações comuns aos dois lados. Poderíamos refletir sobre o que alguns dicionários de música e folclore nos informam a respeito destes termos. Segundo a Enciclopédia da Música Brasileira, tanto o fandango (palavra proveniente da dança espanhola de origem andaluz e castelhana) quanto o cateretê (de origem ameríndia) adquiriram no Brasil, em fins do século XIX, um sentido genérico designando os bailes e as danças populares das províncias do Sul ${ }^{62}$. Sílvio Romero dizia, por exemplo, que o cateretê era em Minas Gerais sinônimo de samba, xiba e fandango ${ }^{63}$. Já no nordeste brasileiro, o fandango é sinônimo de marujada, auto de Natal que emprega cantigas de origem portuguesa, representando a chegança dos marujos mouros e cristãos ${ }^{64}$. Em sua maioria, há características comuns nestes gêneros, como o bater palmas, o sapateado e o emprego de determinados instrumentos, que dão sentido à coincidência de termos. Castelnau foi um dos viajantes que em meados do século XIX presenciou um fandango em solo paraguaio, descrevendo sua estada no Forte Bourbon, às margens do rio Paraguai:

A noite os soldados se reuniram, dançando fandangos, ao som da harpa e do violino. Havia uma graça particular nos movimentos dos homens, que indicavam um grande senso de medida. Era grande o interesse com que contemplávamos estas cenas, novas para nós ${ }^{65}$.

Vimos também que Koslowsky, ao descrever as violas confeccionadas pelos Guató, referiu-se a elas como sendo as mesmas que usavam os índios Chiquitos da Bolívia ${ }^{66}$. Um exemplar destas violas foi fotografado juntamente com outros objetos etnográficos para o Museo de La Plata (figura 4), tendo junto a ela figurado outro instrumento, no formato de alaúde, provavelmente um dos muitos cordofones trazidos à região pelos espanhóis, como é o caso da bandurria, que se incorporou à cultura andina (detalhe da figura 6). Não é possível afirmar se este segundo instrumento foi coletado na expedição de 1894 ou em outra ocasião, porém, as descrições de Koslowsky certamente indicam um caminho para estudos futuros acerca do quanto há de influência hispano-americana na cultura musical brasileira e o

\footnotetext{
${ }^{62}$ Enciclopédia da Música Brasileira. São Paulo: Art Editora, 1977, p. 175-6 e 261-2.

63 Ibidem, p. 176.

${ }^{64}$ CASCUDO, Luís da Câmara. Dicionário do folclore brasileiro. São Paulo: Global, 2001, p. 225.

${ }^{65}$ CASTELNAU, Op. cit., p. 263.

${ }^{66}$ KOSLOWSKY, Op. cit., p. 231.
} 
modo como teriam ocorrido tais intercâmbios. Outro importante indício são as similaridades encontradas pelo pesquisador suíço Luis Fernandez da viola-de-cocho brasileira com a mejorana e o socavon do Panamá67. Estes dois instrumentos folclóricos, provavelmente levados pelos jesuítas espanhóis à América Central, guardam a mesma forma de pera característica das violas-de-cocho, possuem de quatro a cinco ordens simples de cordas e são igualmente construídos a partir de um bloco maciço de madeira (figuras 8 e 9).

De volta à época da criação da capitania de Mato Grosso, encontramos os missionários trazidos por Rolim de Moura também enfrentando enormes dificuldades no estabelecimento de suas aldeias. Através do "Termo de Junta que se fez para a determinação do sítio em que se devia fazer Aldeia", onde o padre Estêvão de Castro justifica a escolha do lugar e reforça a urgência no atendimento àqueles índios, é que se tem conhecimento da atuação do missionário e das condições de vida dos índios aldeados:

Eu que há vinte e três meses cuido no cargo dos Índios para que Deus me chamou e a minha religião me entregou e havendo quatro meses que estou no Cuiabá, em cujo distrito ordena S. Majestade se funde a nova Aldeia para os Índios que estão dispersos e maltratados por alguns moradores, não tenho achado sítio mais cômodo que o da Chapada, [...] é que sendo urgente o recolher a muitos Índios, que nos estão chamando pelo regate da liberdade e má doutrina e tiranias que experimentam, sendo muitos deles ainda por batizar, não obstante que estão há dez e mais anos nas mãos ou poder dos administradores, sendo necessário os recolher já a estes miseráveis $[\cdots]^{68}$.

${ }^{67}$ FERNANDEZ, Luis. La viola de cocho du Mato Grosso. Cahiers de musiques traditionnelles. Musée d'ethnographie de la Ville de Genève, vol. 2, 1989. Apud GUAPO, Milton Pereira de Pinho. Remedeia co que tem. Cuiabá: Carlini \& Caniato, 2010, p. 38.

${ }^{68}$ Termo da Junta que fez para a determinação do sítio em que se devia fazer Aldeias dos Padres da Missão. Revista do Arquivo Público de Mato Grosso, Cuiabá, v. 1, n. 2, 1982, p. 66. 


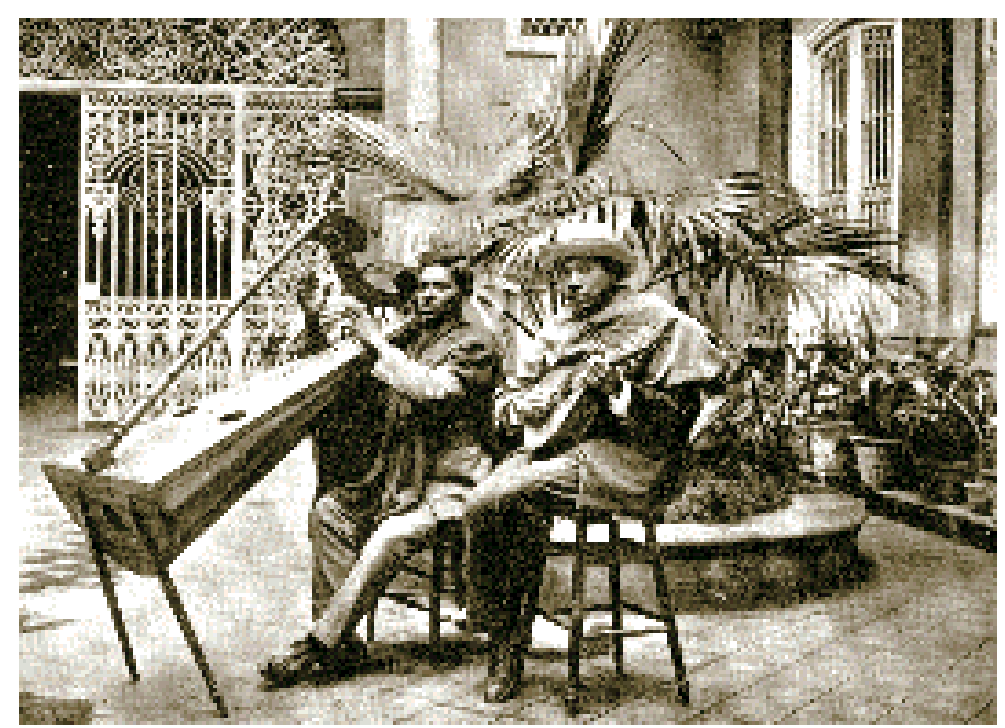

Figura 6: harpa e bandurria, em Cuzco Fonte: Jimenéz, 2012

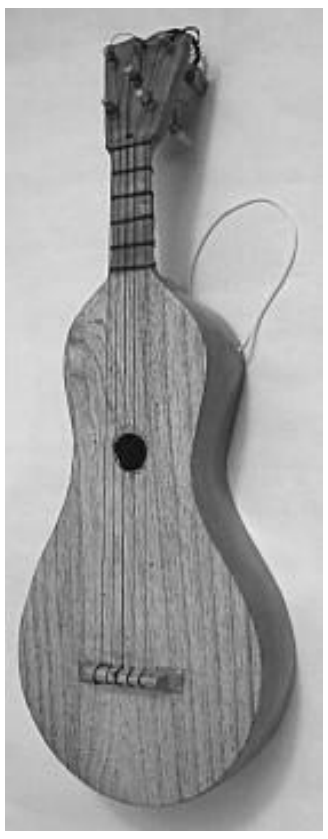

Figura 7: mejorana panamenha Fonte: Jiménez, 2012

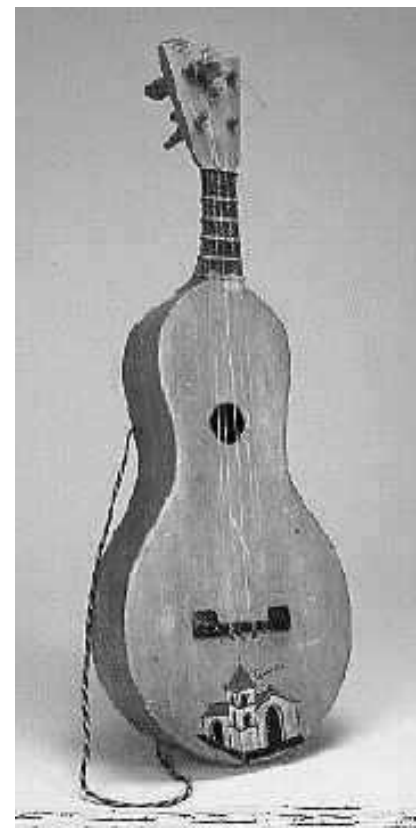

Figura 8: socavon panamenho Fonte: Jiménez, 2012 
A observação do padre Castro era a mesma que Hercules Florence fez mais de sete décadas depois, quando esteve em Chapada dos Guimarães no ano de 1827, notando naquela ocasião que os descendentes dos índios aldeados pelos jesuítas, continuavam vivendo à mercê dos administradores (fazendeiros), "na miséria e quase nada [possuindo] de seu" 69. Tanto os índios aldeados quanto aqueles tidos por administrados contribuíram enormemente para o processo de povoamento da província no séc. XIX, miscigenando-se com negros, brancos e outros índios e integrando-se à vida econômica dos povoados e das fazendas, como trabalhadores pobres (camaradas) que exerciam diversas funções como as de vaqueiros, lavradores, condutores de canoas, remedeiros, seringueiros, extratores de poaia, etc. ${ }^{70}$ Foi na mesma localidade que conheci "Seo Tuti", um caboclo violeiro de mão cheia que me contou como sua família é parte da antiga tradição do Cururu na região. Dentre as memórias, ouvi a de um de seus tios, há muito falecido, que tocava rabeca. Se realmente existiu a prática da rabeca na região, informação que é também fornecida no livro de Loureiro ${ }^{71}$ e na Monografia folclórica sobre o Rio das Garças de Francisco Brasileiro $^{72}$, ela está desaparecida.

Para o padre Agostinho Lourenço, o segundo dos missionários trazidos por Rolim de Moura, as condições eram ainda mais adversas. A população por ele reunida na aldeia de São José, às margens do Guaporé, chegou em 1754 a um número aproximado de 600 índios, tendo logo caído para um terço, em razão das doenças. Haviam ainda as disputas de fronteira com os espanhóis, que se valiam da quantidade maior de missionários e da localização estratégica de suas aldeias para fazer frente aos interesses dos portugueses. Rolim de Moura não só reconhecia as dificuldades inerentes ao trabalho como expressava em carta ao governador do Grão-Pará e Maranhão grande admiração pela figura do padre Lourenço:

Posso assegurar a Vossa Excelência que o Padre Agostinho Lourenço, desde que saiu comigo do Rio de Janeiro, nunca me deu o menor

\footnotetext{
${ }^{69}$ FLORENCE, Op. cit., p. 165-6.

70 SENA, Divino Marcos de. Camaradas: livres e pobres em Mato Grosso (1808-1850). Dissertação de mestrado em história. Dourados, MS: UFGD, 2010, p. 93.

${ }^{71}$ LOUREIRO, Op. cit., p. 61.

72 BRASILEIRO, Monografia folclórica sobre o Rio das Garças. São Paulo: Dep. de Cultura, 1951, p. 341.
} 
motivo de pesar de o haver trazido. [...] tem começado a fundação da Aldeia de São José [...] padecendo nesta empresa fomes, trabalho e doenças, em uma das quais chegou a termos de morrer sem confissão, [...] e sem embargo disso não cessa de trabalhar com a mesma boa vontade ${ }^{73}$.

Os elogios também traduziam o seu pesar em relação às circunstâncias que o obrigavam a providenciar a remoção dos jesuítas que estavam sob o seu governo, em razão da campanha contra a Ordem que culminou no decreto real de expulsão assinado em 3 de setembro do ano seguinte ${ }^{74}$. E o que se viu em seguida ao banimento da Companhia de Jesus das terras brasileiras foi o agravamento dos quadros de abandono e de desestruturação sociocultural por que passaram os índios já aculturados; uma situação ainda mais evidente no território de Mato Grosso que, mesmo povoado por muitas etnias, sofria com a distância e o isolamento em relação ao poder central 75 .

\section{OS ALDEAMENTOS APÓS A EXPULSÃO DOS JESUÍTAS}

Da modesta presença portuguesa da Companhia de Jesus na região, não temos, como foi dito, registros de uma prática musical fomentada pelos seus missionários, ao contrário do que se produziu nas reduções castelhanas construídas a oeste do Guaporé. Ainda assim, é possível ter uma ideia da imagem de bons catequistas e educadores musicais mantida pelos jesuítas, através de documentos como o da resposta do capitão-general Caetano Pinto de Miranda Montenegro, que governou Capitania de Mato Grosso de 1796 a 1803, ao parecer do Capitão de Engenheiros do Forte Novo de Coimbra, Ricardo Franco de Almeida Serra, que não recomendava o aldeamento dos índios Guaicuru e Guaná naquelas proximidades. Em carta de 1803, o governador discordava da análise do militar, se reportando à eficácia do método dos inacianos:

\footnotetext{
${ }^{73}$ [MOURA, Rolim de]. Carta de 15 de novembro de 1758 a Francisco Xavier de Mendonça Furtado. Rolim de Moura: correspondências. Coleção documentos ibéricos - série: Capitães-generais n. 4 vol. 3. Cuiabá: UFMT, 1983, p. 144-145.

${ }^{74}$ CORRÊA FILHO, Virgílio. História de Mato Grosso. Rio de Janeiro: Instituto Nacional do Livro, 1969, p. 337.

${ }^{75}$ MOUTINHO. Joaquim Ferreira. Notícia sobre a província de Mato seguida d'um roteiro da viagem da sua capital a S. Paulo. São Paulo: Typografia de Henrique Schroeder, 1869, p. 131.
} 
[...] escolheria homens proporcionados para tal empresa, animados de um verdadeiro zelo pelo serviço de Deus e do Estado, e que sem terem a ambição jesuítica, tivessem a mesma arte e indústria, com que eles ordinário ganhavam o coração desta gente. Nas mesmas povoações, colocadas em terreno saudável, próprio para a cultura, e abundante de caça e peixe, faria casas, cômodos, templos que infundissem respeito, e não me esqueceria da grande influência que tem a música em homens ainda novos, e que não estão ainda safados com a multiplicidade de sensações ${ }^{76}$.

Montenegro não só aponta a catequese como o instrumento mais eficaz para a integração do índio à ordem social da Colônia, como também reconhece na atuação pioneira dos padres expulsos pelo decreto de 1759 o modelo a ser adotado pelos novos missionários. Só não deveriam ser eles, por conta da "ambição jesuítica", os responsáveis pela administração temporal dos índios, conforme determinava o Alvará de 7 de junho de 175577. Segundo a mesma lei, também denominada Diretório Pombalino, caberia aos governos das Capitanias a proteção dos índios, reunindo-os sob a administração de um missionário ou de um leigo, para no futuro "incorporá-los aos demais habitantes" 78. Era esta a estratégia da Coroa Portuguesa para o povoamento dos sertões, deslocando grupos indígenas já civilizados para os povoados próximos e encorajando a sua integração por intermédio da mestiçagem.

Em 1819, os índios Guaná que habitavam esta mesma região, à época chamada baixo Paraguai, foram reunidos na Missão de Nossa Senhora da Misericórdia, situada próxima à freguesia de Albuquerque (atual município de Corumbá, MS). Seu fundador, o missionário capuchino José Maria Macerata, foi durante quatro anos o responsável pela catequese daqueles nativos, até assumir a prelazia de Cuiabá, em 1823. Vários Guaná, segundo Verone Cristina da Silva, seguiram o padre Macerata na

\footnotetext{
${ }^{76}$ Resposta do General Caetano Pinto de Miranda Montenegro ao Parecer sobre o aldeamento dos índios Uaicurus e Guanás, com a descrição dos seus usos, religião, estabilidade e costumes, por Ricardo Franco de Almeida Serra. Revista do Instituto Histórico e Geográfico de Mato Grosso - tomo CXLVI, ano LXX. Cuiabá, 1898, p. 216 (grifo meu).

${ }^{77}$ Diretório que se deve observar nas Povoações dos Índios do Pará, e Maranhão. Alvará de 7 de junho de 1755. Disponível em:

< http://www.iuslusitaniae.fcsh.unl.pt/verlivro.php?id_parte=105\&id obra=73\&pagina=532 > Acesso em: 03/09/2013.

${ }^{78}$ SILVA, Verone Cristina. Missão, aldeamento e cidade: os Guaná entre Albuquerque e Cuiabá (1819-1901). Dissertação de mestrado em história. Cuiabá: UFMT, 2001, p. 77
} 
sua transferência para a capital, sobretudo entre os anos 1843 e 1844, e se aldearam à margem direita do rio Cuiabá, em frente ao Porto Geral ${ }^{79}$. Estes índios, como veremos adiante, foram aos poucos se integrando à população cuiabana, trazendo parte de suas histórias para cultura dos lavradores ribeirinhos, pescadores e artesãos.

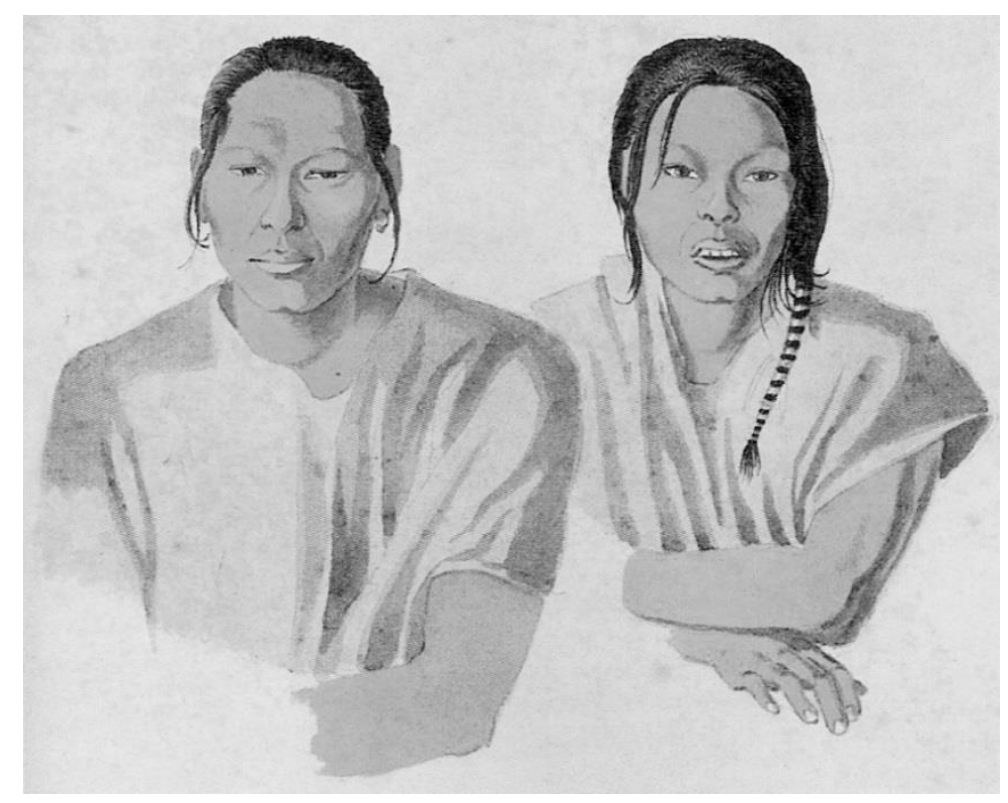

Figura 9: Florence, Índios Guaná (1827)

Fonte: Siqueira, 2002

Com o Decreto Imperial no 426, de 24 de julho de 1845, todos os aldeamentos da Província passaram à administração da Diretoria Geral dos Índios e assim o novo órgão manteve a mesma política de meados do século XVIII, determinada pelo Diretório Pombalino ${ }^{80}$. Foi através da documentação do novo órgão que Verone Cristina da Silva pesquisou as origens da Missão de Nossa Senhora do Bom Conselho, também fundada nas proximidades de Albuquerque, na localidade chamada MatoGrande. Esta missão, que tinha na maioria dos seus índios aldeados os Kinikináo, considerados um subgrupo da etnia Guaná, contava na época de sua implantação com

\footnotetext{
79 Ibidem, p. 10.

${ }^{80}$ Decreto no 426 de 24 julho de 1845, que contém o regulamento acerca das Missões de catequese e civilização dos índios. Disponível em:

<http://legis.senado.gov.br/legislacao/ListaTextolntegral.action?id=66320\&norma=82240 > Acesso em: 03/09/2013.
} 
um diretor permanente, um missionário apostólico e três instrutores (um professor de primeiras letras, outro de música e uma mestra de costura) ${ }^{81}$.

O cronista português Joaquim Ferreira Moutinho visitou a referida aldeia, em 1862, na época dirigida pelo frei Agnelo de Caramanico:

0 aldeamento de mais digna menção na província era o dos Quiniquináos, na aldeia do Bom Conselho em Albuquerque. [...] Os rapazes formavam uma excelente banda de música, e as raparigas todas, muito bem vestidas e calçadas, dançavam perfeitamente. [...] Haviam escolas de primeiras letras e música, onde estudavam com muito aproveitamento. [...] Falavam entre si a língua geral, mas conheciam perfeitamente a portuguesa, e se exprimiam claramente ${ }^{82}$.

Os aldeamentos subordinados à Diretoria Geral dos Índios tiveram, em vários casos, o seu funcionamento descontinuado, não só pela carência de recursos mas ainda pelos crescentes deslocamentos daquelas populações para as cidades. Também foram trágicos os efeitos da invasão paraguaia de 1865 e a epidemia de varíola que tomou conta da Província em 186783. Com isso, o destino provável de grande parte dos Kinikináo sobreviventes foi a periferia de cidades como Cuiabá e Corumbá; porém, somos levados a indagar se teria a experiência da Missão de Nossa Senhora do Bom Conselho alguma relação com o Cururu "de acentuados elementos religiosos" praticado na década de 1950 pelos kinikináo do rio Taquari, a mesma região do baixo Paraguai 84 .

Uma iniciativa mais recente e digna de nota, ocorrida de certo modo nos moldes das intervenções dos padres católicos do século XVIII e XIX, foi a das missões da Congregação Salesiana junto aos Bororo e Xavante, na região do Sangradouro, sudeste de Mato Grosso. Em 1904, após tentativas frustradas de transferência das colônias indígenas que estavam sob o controle de militares e que haviam sido extintas na década anterior, os salesianos decidiram estabelecer-se autonomamente, comprando a fazenda Sangradouro Grande e iniciando a assistência às tribos Bororo

\footnotetext{
${ }^{81}$ SILVA, Op. cit., p. 59.

${ }^{82}$ MOUTINHO, Op. cit., p. 135-37.

${ }^{83}$ SILVA, Op. cit., p. 120.

${ }^{84}$ DÖPPENSCHMIDT apud CANDIDO, Op. cit., p. 388.
} 
dispersas na região. Os índios, após sua instalação na colônia Sagrado Coração, assimilaram o uso de roupas e nomes cristãos, se dispuseram a frequentar missas e a trabalhar em oficinas e plantações, mas não abriram mão da essência de sua cultura, preservando ao longo dos anos costumes e práticas rituais próprias. Isso obrigou os padres a rever suas estratégias de catequese, sendo tolerantes, a contragosto, com práticas como "cantos, jogos, ritos de nominação e iniciação, funerais, etc" ${ }^{85}$. Ao que parece, não estiveram em jogo negociações em torno de expressões híbridas do cancioneiro local, no entanto, a experiência em Sangradouro representou bem o modo como continuam a se processar trocas, conflitos e acomodações resultantes de uma das mais importantes relações interculturais da história brasileira.

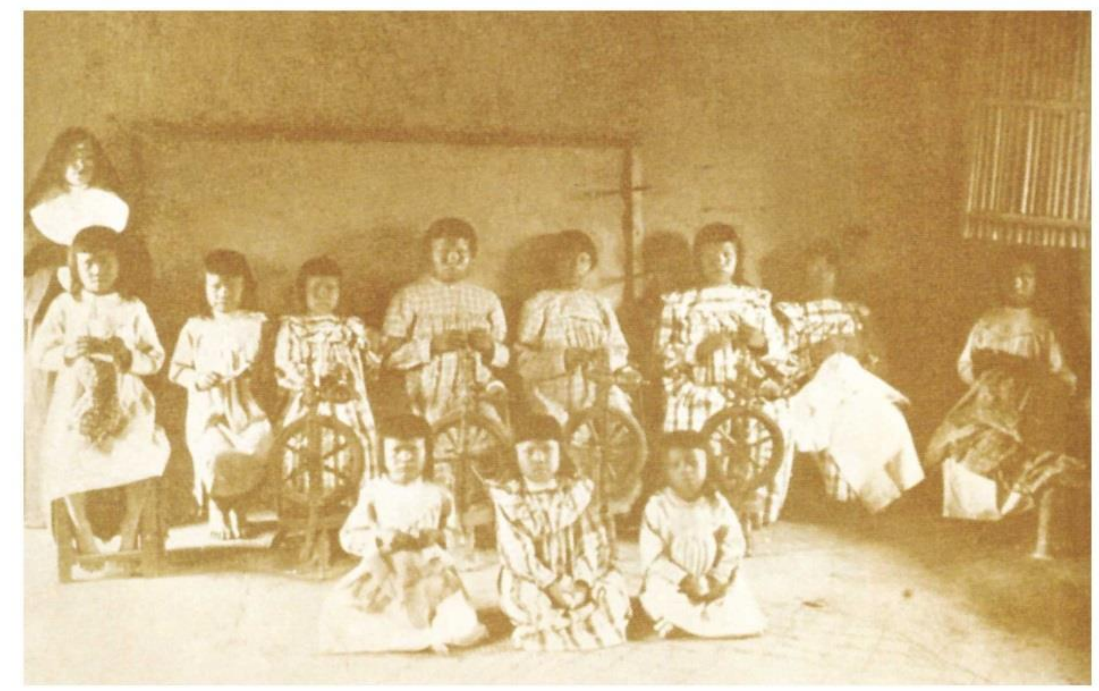

Figura 10: oficina de tear da Missão Salesiana em MT (1908)

Fonte: Lucidio, 2008

\section{NOS ARREDORES DAS CIDADES}

A partir da década de 1850, os índios que se deslocaram para os arredores das cidades de Mato Grosso irão se integrar cada vez mais àqueles espaços, tanto como força de trabalho quanto como beneficiários dos serviços públicos ${ }^{86}$. Terão seus nomes relacionados a ocorrências criminais, quase sempre associadas a confusões,

85 CAREAGA, Aroldo. Salesianos e Bororo nos sertões mato-grossenses: das práticas missionárias às resistências culturais (1894-1910). Revista Nures n. 16, Set/Dez 2010 - Núcleo de Estudos Religião e Sociedade - Pontifícia Universidade Católica - SP p. 2 Disponível em:

< http://www.pucsp.br/revistanures > acesso em: 02/10/2014.

86 SILVA, Op. cit., p. 115. 
como as que citamos anteriormente neste capítulo. Em processos envolvendo os Guaná que viviam em frente ao Porto Geral de Cuiabá, estes serão reconhecidos como índios, porém tratados como os demais moradores pobres da cidade. Dentre os exemplos, figura o caso de assassinato de uma índia por seu marido, morto em seguida pelo cunhado:

O assassinato da índia Rosa teve por princípio o estado de embriaguez de seu marido Miguel dos Santos que nesse dia assistia a um festejo, depois do qual entrou com ela em alterações dando-lhe a final uma facada de que logo sucumbiu; acudiu em socorro o índio José da Silva e sendo ofendido, ainda que levemente, retirou-se, vindo então o índio Francisco Antônio, irmão da assassinada, que deu no dito Miguel uma facada de que morreu no dia seguinte, apesar de todos os socorros que lhe foram ministrados pela Santa Casa de Misericórdia. Procedeu-se o respectivo subdelegado a exame e corpo de delito em todas as ofensas, fazendo logo prender e recolher à cadeia o índio Francisco Antônio ${ }^{87}$.

Em sua crônica publicada em 1869, Moutinho também se refere ao cotidiano dos Guaná da mesma localidade, dizendo: "fazem ainda suas festas e danças que terminam sempre pela embriaguez a que todo índio é afeiçoado" 88. Há que se perguntar que tipo de festejo era aquele em que o citado crime ocorreu. Teria sido uma festa animada pelo Cururu? Outro exemplo de agressões entre familiares motivado pelo uso da bebida é a ocorrência de julho de 1852:

Houve no último dia da semana passada (10 do corrente) um homicídio em S. Antonio do Rio Abaixo perpetrado pela Índia Maria na pessoa de seu marido o Índio José. Fez-se corpo de delito, e está a delinquente na cadeia, as cousas que até agora sei, não são mais que a embriaguez de ambos que nesse estado brigaram em sua mesma casa $^{89}$.

Ademais, os Guaná oriundos de Albuquerque, que inicialmente se instalaram na margem direita do rio Cuiabá, já estavam na década de 1860 integrados à vida

\footnotetext{
${ }^{87}$ Doc. Avulso, Cuiaba, 1 o de outubro de 1853. LATA 1853 B, APMT. Apud. SILVA, p. 107-108.

${ }^{88}$ MOUTINHO, Op. cit., p. 138.

89 Illmo. Exmo. Capitão de Fragata Augusto Leverger Presidente e Commandante das Armas da Provincia. Cuiaba, 1ㅇ de agosto de 1852. Lata 1852 A, APMT. Apud. SILVA, p. 110.
} 
local, ao ponto de os mais jovens viverem entre os demais habitantes da capital e merecerem elogios de Moutinho quanto à sua aparência civilizada:

Em frente ao Porto Geral, da cidade de Cuiabá, na margem direita do rio está um aldeamento de guanás, que se empregam no serviço de camaradas. Estes índios de boa índole podem-se dizer perfeitamente civilizados, e apenas alguns velhos restam no aldeamento, porque os demais estão confundidos com a população da cidade. Têm tipos muito bonitos; as raparigas vestem-se bem, e não gastam absolutamente fazenda ordinária; os seus vestidos são feitos por elas mesmas, ao passo que cuidam também das roupas de seus maridos e filhos $\left[\ldots . .{ }^{90}\right.$.

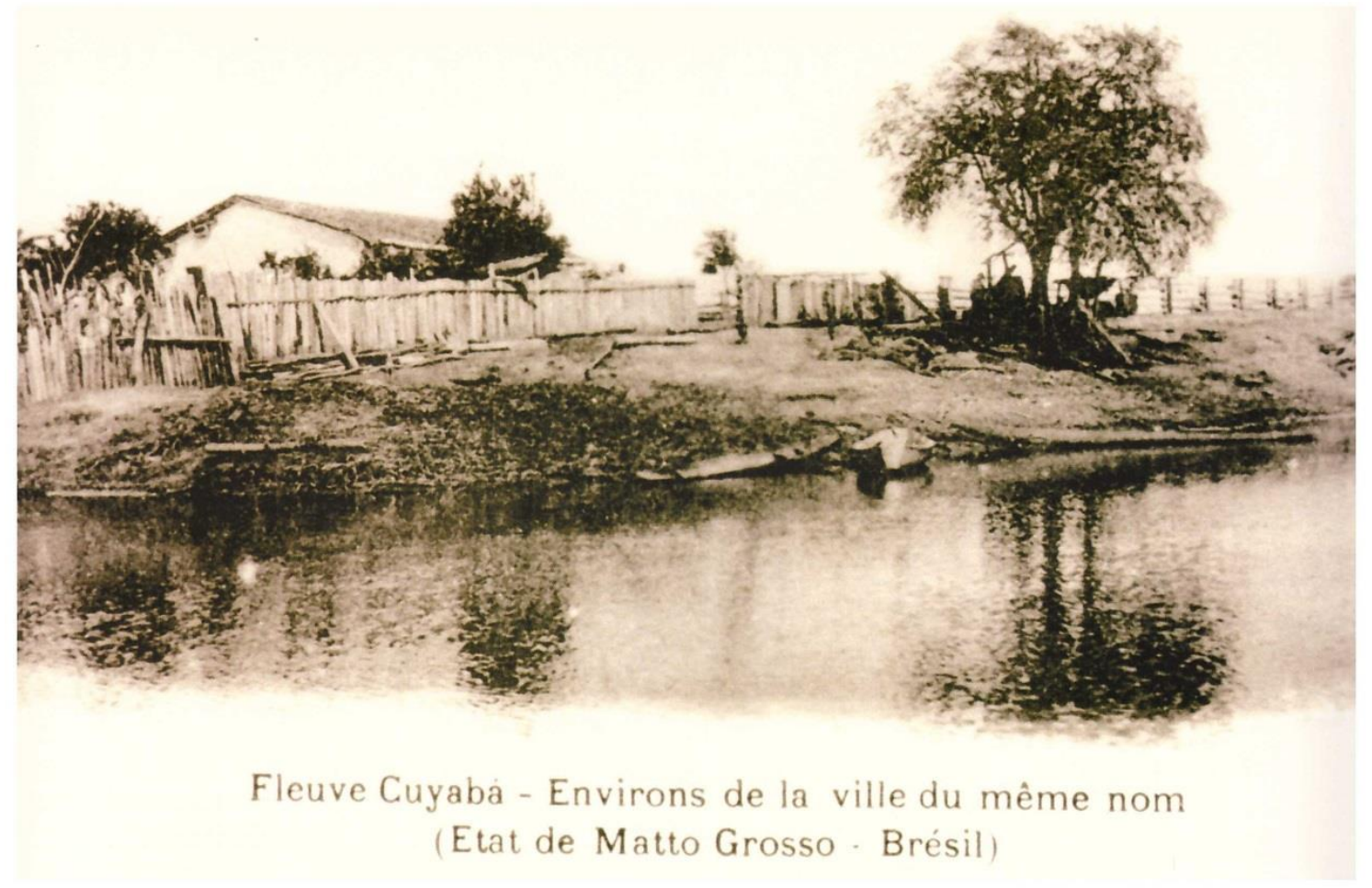

Figura 11: cartão postal das margens do rio Cuiabá (1902)

Fonte: Lucidio, 2008

Os que permaneceram em suas choças às margens do Cuiabá, sobretudo os mais velhos que, no dizer de Moutinho, mantiveram em seus costumes "um misto dos usos bárbaros com os da civilização", serão cada vez mais identificados genericamente como os ribeirinhos que "caçam, pescam plantam suas roças, criam

\footnotetext{
${ }^{90}$ MOUTINHO, Op. cit., p. 138.
} 
galinhas, porcos, etc., e vivem finalmente em completa harmonia com os nossos costumes" 91.

Na periferia do município de Cáceres, no bairro Jardim Cohab Nova, conheci o Sr. Lourenço Ferreira Mendes, o cururueiro e artesão de violas mais conhecido daquela cidade. Mestre Lourenço é membro fundador de associações folclóricas na cidade, incluindo o Grupo Guató, vinculado aos programas de extensão da Universidade Estadual de Mato Grosso - UNEMAT. Na ocasião, pude observar os modos de vida mais recentes de muitos dos ribeirinhos que hoje vivem nas principais cidades de Mato Grosso e que têm no artesanato e no Cururu e Siriri exibidos nas formas de espetáculo o seu principal meio de subsistência. A antiga prática, que antes era mal vista pela sociedade e reprimida pelas autoridades policiais, hoje se "civiliza" e se transforma em vitrine regional para a nação.

À maneira das tribos nativas que nos primórdios da colonização europeia tiveram a sua vida sociocultural e ecológica desestruturada pelas novas circunstâncias, uma grande parcela dos índios das regiões do Pantanal e Mato Grosso encontrou na assimilação dos modos de vida do colono e do missionário catequista uma solução possível para a sua existência. Estes índios adotaram o cancioneiro brasilíndio como sua música sem que, no entanto, a vida religiosa e recreativa se conformasse inteiramente aos modelos de devoção e civilidade esperados. Por sua vez, os colonos só puderam se firmar de forma mais efetiva naquele novo ambiente quando se somaram à força produtiva dos nativos, conformando-se à natureza local e engrossando seus contingentes através da miscigenação, Neste contexto, o lazer com música e dança tornou-se importante fator de aproximação destes dois mundos, caracterizado desde o início por uma prática permeada de negociações e influências mútuas. Como exemplo deste sincretismo, citaríamos o costume nem sempre aceito das funções de Cururu, meio religiosas e meio pagãs, que, não raro, terminavam de forma violenta, como nos festejos de Bracinho, na beira do São Lourenço. Além disso, o exemplo da etnia Bacairi do Rio Novo, que, mesmo tendo tomado para si a prática da viola do colono, não deixara de impressionar Steinen com seus cantos e rituais primitivos. Esses modos particulares de adaptar e incorporar valores constituíram-se,

\footnotetext{
${ }^{91}$ Idem.
} 
ao final, num processo bem mais complexo que a noção de deculturação indígena defendida por antropólogos como, Darcy Ribeiro - e que também foram usadas por folcloristas como Gallet - uma vez que seus personagens conferiram novos sentidos à assimilação, à maneira do que enxergou Certeau a respeito dos índios da América espanhola:

[...] mesmo subjugados, ou até consentindo, muitas vezes esses indígenas usavam as leis, as práticas ou as representações que lhes eram impostas pela força ou pela sedução, para outros fins que não os dos conquistadores. Faziam com elas outras coisas: subvertiamnas a partir de dentro - não rejeitando-as ou transformando-as (isto acontecia também), mas por cem maneiras de emprega-las a serviço de regras, costumes ou convicções estranhas à colonização da qual não podiam fugir. Eles metaforizavam a ordem dominante: faziam-na funcionar em outro registro ${ }^{92}[\ldots]$.

Se não se pode afirmar de modo categórico que a tradição musical da região surge primeiramente da interação do índio com o missionário católico - uma vez que esta era provavelmente a mesma cultura trazida pelo bandeirante, o colono ou o mineiro; grupos, enfim, que já possuíam em sua trajetória uma expressiva carga de miscigenação - a história nos permite identificar experiências em que índios e seus descendentes, por vezes "escondidos" na condição de "ribeirinhos", se revelam representantes de uma prática arcaica como a do Cururu. Uma mesma história que também nos mostra pontos de intersecção entre os nativos e a presença espanhola na região, podendo ela ter determinado algumas das particularidades manifestadas na cultura do lugar. Daí o fato de o mesmo sabor ameríndio citado por Mário de Andrade ser notado nas danças e cantorias ainda cultivadas em localidades mais velhas do Estado, como Cuiabá, Poconé, Nossa Senhora do Livramento, Diamantino, Rosário, Chapada dos Guimarães e Santo Antônio do Leverger. Especialmente nas festas de santos tradicionalmente comemoradas nas casas de famílias.

\footnotetext{
${ }^{92}$ CERTEAU. Michel de. A invenção do cotidiano: artes de fazer. Petrópolis, RJ: Vozes, 1994, v.1, p. 94-5.
} 


\title{
CAPÍTULO IV
}

\author{
FESTA E DEVOÇÃO
}

Os sinos e os tiros anunciam a ressurreição de Cristo e a abolição do luto. Neste dia, quando as lojas já abriam as suas portas, as igrejas ainda eram visitadas e à noite toda a cidade dançava.

Karl von den Steinen, Através do Brasil Central, 1886

A julgar pela crônica referida neste estudo, as festas do calendário católico em Mato Grosso representavam, em mais de uma época, um dos pontos altos da vida comunitária e da cultura tradicional da região. Nem mesmo as mais importantes efemérides cívicas e as comemorações de cunho familiar, como os casamentos e batizados, rivalizavam em prestígio com os festejos dos dias santos. É como Steinen parecia ver a celebração dos feriados da Semana Santa e das festas de Pentecostes em Cuiabá, no ano de 1884. O envolvimento de toda a cidade com as procissões, os sermões ao ar livre, a missas solenes e as festas das esmolas, além da dimensão teatral daqueles momentos festivos, fizeram o viajante alemão confessar estarem todos os membros de sua comitiva constantemente "movidos" pela emoção reinante1. Do mesmo modo, a pompa e o luxo ostentados na festa de São Benedito impressionaram Florence, por ocasião de sua visita a Diamantino, em 1838. Era uma prestigiada festa oferecida por um negro de posses daquela região mineradora, distante 36 léguas ao norte de Cuiabá, que costumava reunir entre os seus convidados todas as pessoas importantes da cidade e seus arredores ${ }^{2}$. Castelnau, sem disfarçar seu desconforto com o clima insalubre da região de Vila Bela, surpreendeu-se com o

\footnotetext{
${ }^{1}$ STEINEN, Karl von den. O Brasil Central: expedição em 1884 para a exploração do rio Xingu. São Paulo: Cia Ed. Nacional, 1942, p. 86-92.

${ }^{2}$ FLORENCE, Hercules. Viagem fluvialdo Tietê ao Amazonas de 1825 a 1829. Brasília: Senado federal, 2007, p. 201.
} 
número de fiéis reunidos nas cerimônias do dia de Santo Antônio, no ano de 1854, no povoado que havia sido a antiga capital da Província e que vivia àquela época um acentuado declínio econômico e populacional ${ }^{3}$. Também citadas anteriormente, as comemorações de Ano Novo e a Festa da Imaculada Conceição do povoado de Rosário do Rio Acima foram, já no início do século seguinte, a ocasião em que Max Schmidt testemunhou pela primeira vez em Mato Grosso "danças e cantos brasileiros", incluindo o Siriri e o Cururu4 4

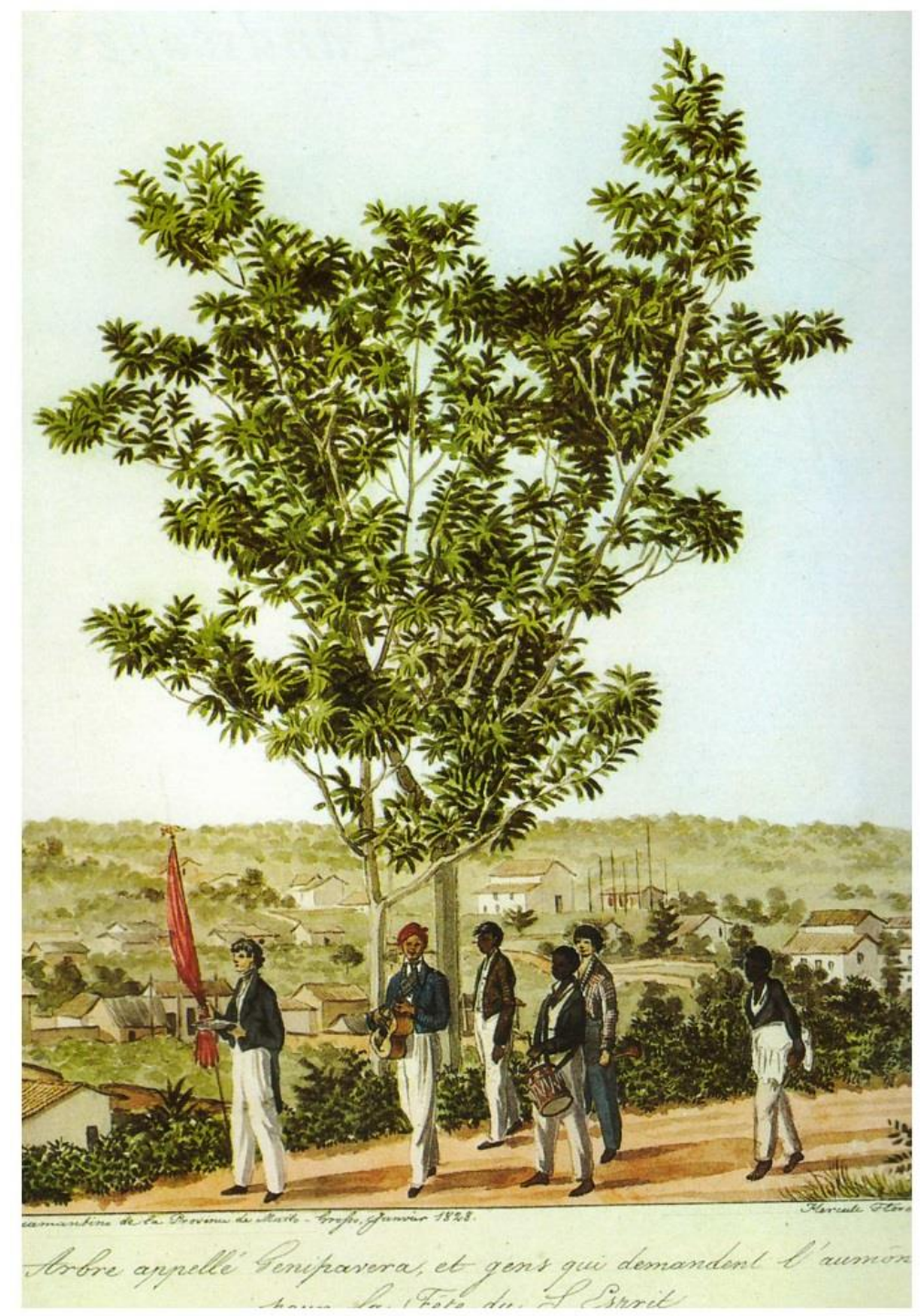

Figura 1: Florence, Bandeira do Divino em Diamantino Fonte: Loureiro, 2006

\footnotetext{
${ }^{3}$ CASTELNAU, Francis de. Expedição às regiões centrais da América do Sul. São Paulo: Cia Ed. Nacional, 1949, tomo II, p. 364.

${ }^{4}$ SCHMIDT, Estudos de etnologia brasileira: peripécias de uma viagem entre 1900 e 1901. São Paulo: Cia Ed. Nacional, 1942, p. 13-4. Ver também p. 77-9 do cap. II desta tese.
} 
De certo modo, estas impressões acompanharam o senso comum dos cronistas europeus que estiveram anteriormente em terras brasileiras, alguns deles como partícipes diretos do projeto de implantação da fé católica na América portuguesa. As cartas e os tratados jesuíticos do período colonial são exemplos pioneiros desta narrativa, com suas doutrinas ora reconhecendo nos povos não europeus elementos formadores de uma nova cristandade (advogando, com isso, o lugar do índio no reino das criaturas de Deus), ora justificando a opressão política e mercantil como partes desta expansão religiosa. Através dos relatos enviados a seus superiores e dos fragmentos históricos por eles escritos, Manuel da Nóbrega e José de Anchieta retrataram as contradições do esforço missionário daqueles primeiros anos, que em muitas vezes apontava a guerra e a submissão atroz do índio ao trabalho escravo pelo colono como o meio possível para a evangelização. Fernão Cardim, que esteve no Brasil como visitador e provincial da Companhia de Jesus, também narra em sua obra o complexo processo de conversão do gentio, nos períodos de 1583 a 1598, e de 1604 a 1609, juntamente com o interesse dos seus pares pelo abandono gradativo dos costumes considerados bárbaros em suas festas e a sua substituição pelas celebrações de cunho cristão. Mais adiante, os padres Antônio Vieira e João Felipe Bettendorff desempenham o mesmo papel ao norte da Colônia, nas capitanias do Grão-Pará e Maranhão, buscando manter na catequese dos índios uma proximidade maior com os chefes das tribos locais. Também se colocam contrários ao aproveitamento indiscriminado da mão-de-obra indígena pelos colonos da região, embora se queixem dos costumes por eles considerados perniciosos e da resistência à conversão por parte destes mesmos nativos ${ }^{5}$. 0 relato dos missionários inacianos deste período refere-se, portanto, aos desafios e sucessos da empresa colonizadora encampada pelos países ibéricos, que incluía a expansão da cristandade por todos os domínios além-mar, ainda que fosse necessário usar a força das armas. Ao mesmo tempo, nos fala da capacidade de resistência não direta da cultura desses povos convertidos, resistência esta que fez surgir novas formas de expressão religiosa, conforme veremos neste capítulo.

\footnotetext{
${ }^{5}$ HOORNAERT, Eduardo (Org.) História da lgreja no Brasil: ensaio de interpretação a partir do povo. Petrópolis, RJ: Vozes, 1992, tomo II, v. 1, p. 321.
} 
Ainda mais adiante, a narrativa dos naturalistas estrangeiros que nas primeiras décadas do século XIX percorreram os sertões do norte, nordeste e centrosul revela a tradição das festas católicas, já entranhada em grande parte do território brasileiro. A afluência destes viajantes e o interesse pelo estudo das populações brasileiras ocorrem no contexto da transferência da corte portuguesa para o Brasil, da abertura dos portos e da expansão do comércio mundial, com um grande impulso dado às ciências naturais pelas principais nações europeias e o interesse pelo conhecimento dos territórios mais distantes do Velho Mundo. Este momento é descrito por Sérgio Buarque de Holanda como um "novo descobrimento" do território brasileiro $^{6}$, quando o olhar estrangeiro se orienta preferencialmente pelos caminhos do Brasil de dentro, em um movimento cujo encontro com a natureza exuberante dos trópicos e os seus tipos humanos irá produzir um discurso que opõe a imagem do sertão à do litoral e ressaltará a necessidade do povoamento e da integração econômica como motores do processo civilizatório. A expedição do príncipe renano Maximiliano Wied-Neuwied, que por dois anos percorreu o Rio de Janeiro, Espírito Santo e Bahia, é um dos exemplos. Noticiou os festejos anuais em homenagem ao Espírito Santo e a São Sebastião, nos distritos de Vila Nova e Ilhéus, incluindo o modo como o culto católico influenciou os costumes dos índios dessas regiões ${ }^{7}$. 0 botânico francês Auguste de Saint-Hilaire é outro viajante que nos mostra a importância das festas religiosas nos povoados de Minas e Goiás, com destaque para o esmero com que os moradores se vestiam nos dias santos e o modo como desfrutavam de uma comida farta durante esses dias, apesar da escassez de recursos no dia-a-dia ${ }^{8}$. 0 mesmo interesse pode ser destacado no relato dos exploradores bávaros Spix e Martius, caracterizando a vida rude dos habitantes dos sertões de Minas pela ausência de uma moral condizente com o ideal de civilidade defendido àquela época. Para eles, mesmo se devotando a práticas festivas cuja ostentação demandava muitas vezes um ano inteiro de sacrifícios, os sertanejos cultivavam hábitos sociais

\footnotetext{
${ }^{6}$ HOLANDA, Sérgio Buarque de (org.). A herança colonial: sua desagregação. In História geral da civilização brasileira. São Paulo: Difel, 1976, tomo II, vol. 1, p. 13.

${ }^{7}$ WIED-NEUWIED, Maximilian. Viagem ao Brasil nos anos de 1815 a 1817. São Paulo: Cia Ed. Nacional, 1940, p. 345.

${ }^{8}$ SAINT-HILAIRE, Auguste de. Viagem às nascentes do rio S. Francisco e pela província de Goyaz. São Paulo: Cia. Ed. Nacional, 1937, p. 30.
} 
considerados moralmente frouxos, em função da mestiçagem e da vida "em estado de natureza" 9 .

O tema central deste capítulo é o modo como a religião popular se configurou em Mato Grosso através das suas festas de santos. Para desenvolvê-lo, busco em algumas das atuais representações festivas locais os rastros de um passado que teve na Igreja católica uma das principais forças coordenadoras na implantação em terras brasileiras do projeto civilizatório lusitano. Imagens deste Brasil antigo estão presentes em outros tantos momentos da sua formação, com crenças, cultos e ritos preservados junto às suas paróquias, irmandades e famílias, sendo estes exemplos aqui utilizados como fontes para uma etnografia do tema na região. Inicio apresentando as festas católicas tradicionais dos municípios mato-grossenses de Cuiabá, Poconé e Rosário Oeste, incluindo Corumbá, em Mato Grosso do Sul, a partir da observação de folcloristas e etnógrafos como Roberto Loureiro, Maria de Lourdes da Silva Ramos e Eunice Rocha. São elas as festas do Divino, São Benedito, São João, São Gonçalo e Sant'Ana. Este retrato é complementado com dados de minhas pesquisas de campo, realizadas em Mato Grosso nos meses de junho e julho de 2012, ocasião em que pude presenciar aspectos da tradição mantidos vivos ao longo dos períodos, como nos ritos da subida do mastro e da lavagem dos santos, entre outros. Também trago o testemunho de novidades tomadas de formas de lazer mais recentes, como nos casos da utilização de músicas gravadas por meios eletrônicos nos bailes e a montagem de palcos para a apresentação de danças e cantos que antes eram cultivados coletivamente, pela maioria dos participantes. Na sequência, o quadro desta análise é ampliado através da abordagem de algumas manifestações de religiosidade popular ocorridas em mais de uma região brasileira, a partir de práticas que podemos considerar afins. Utilizando exemplos de registros do Período Colonial, do Império e dos primeiros anos da República, também procuro relativizar as noções hoje frequentemente difundidas acerca de manifestações consideradas típicas de um só lugar, comparando entre si expressões como a festa de Ramos na aldeia de São João (Espírito Santo, 1584), os mascarados da festa de São Sebastião em Ilhéus

\footnotetext{
${ }^{9}$ SPIX, Johann Baptist von e MARTIUS, Carl. Friedrich Philipp von. Viagem pelo Brasil: 1817-1820. São Paulo: Melhoramentos, 2a ed. s.d., v. 2 p. 80.
} 
(Bahia, 1817), a bandeira do Divino em Diamantino (Mato Grosso, 1838), e a folga de São Benedito em Destacamento (Espirito Santo, 1859).

O cultivo destas festas, ao mesmo tempo em que buscou ordenar a sociabilidade em torno do ideário católico, através da introdução de elementos eruditos da tradição ibérica, permitiu desde o seu início a aproximação de práticas populares europeias com ritos de origem indígena e africana, dando forma a um catolicismo camponês repleto de traços locais. Carlos Rodrigues Brandão ressalta o papel formador dos diversos agentes dessa religião popular (capelães, rezadoras, benzedeiras, mestres cantadores e folgazões em geral), reconhecendo haver ao longo da sua trajetória poucos espaços sociais onde "o poder dos fracos [conseguiu] ser tão consistente e criativo" ${ }^{10}$. Combinando o sacro e o profano em suas rezas, danças, simpatias, comidas e procissões, a experiência desses homens e mulheres nos permite relacionar sua história não só aos ritos católicos dos aldeamentos jesuítas e arraiais dos colonos dos primeiros séculos no Brasil, como também às práticas populares da Europa no início da era moderna, onde às camadas subalternas eram permitidos espaços de aproximação, de sincretismos e de simulacros de uma maior permeabilidade social.

\section{AS FESTAS CATÓLICAS EM MATO GROSSO}

As festas do Divino Espírito Santo e São Benedito são, segundo Loureiro, as mais tradicionais celebrações de santos na Capital. Hoje organizadas por comissões pastorais mais diretamente ligadas à hierarquia da Igreja, elas eram até a década de 1980 promovidas por confrarias regidas por leigos. No caso das festas citadas, a Irmandade do Senhor Divino e as Irmandades de Nossa Senhora do Rosário e São Benedito, respectivamente ${ }^{11}$. Agremiações como estas eram comuns no Brasil colonial, sobretudo nas regiões mineradoras onde nem sempre o catolicismo se fazia presente através das suas instâncias oficiais. No lugar de um vínculo direto do clero com a população, a vida religiosa era mediada por tais confrarias, que, além de manter o culto ao seu santo padroeiro, também promoviam a solidariedade entre

\footnotetext{
${ }^{10}$ BRANDÃO, Carlos Rodrigues. Os deuses do povo: um estudo sobre a religião popular. Uberlândia, MG: EdUFU, 2007, p. 142.

${ }^{11}$ LOUREIRO, Roberto. Cultura mato-grossense: festas de santos e outras tradições. Cuiabá: Entrelinhas, 2006, p. 25.
} 
seus membros, cuidando dos enfermos, sepultando os mortos e amparando seus órfãos e viúvas. Embora cada uma delas tivesse um compromisso ou estatuto firmado junto à Coroa e representantes da Igreja, reunidos no sistema de padroado, as irmandades possuíam considerável autonomia, inclusive para o emprego de suas finanças em melhorias públicas como a abertura e a manutenção de caminhos e pontes que serviam aos peregrinos. Também à população negra era permitido que se congregasse, porém mantendo a mesma distinção existente nos demais setores da vida social, o que possibilitou a formação de confrarias como as dos "homens pretos" e dos "homens pardos". Irmandades como as de Nossa Senhora do Rosário e São Benedito possuíam a prerrogativa de angariar recursos não só para a edificação de suas capelas e a promoção de suas festas, como também para o amparo seus membros, incluindo a compra de cartas de alforria ${ }^{12}$.

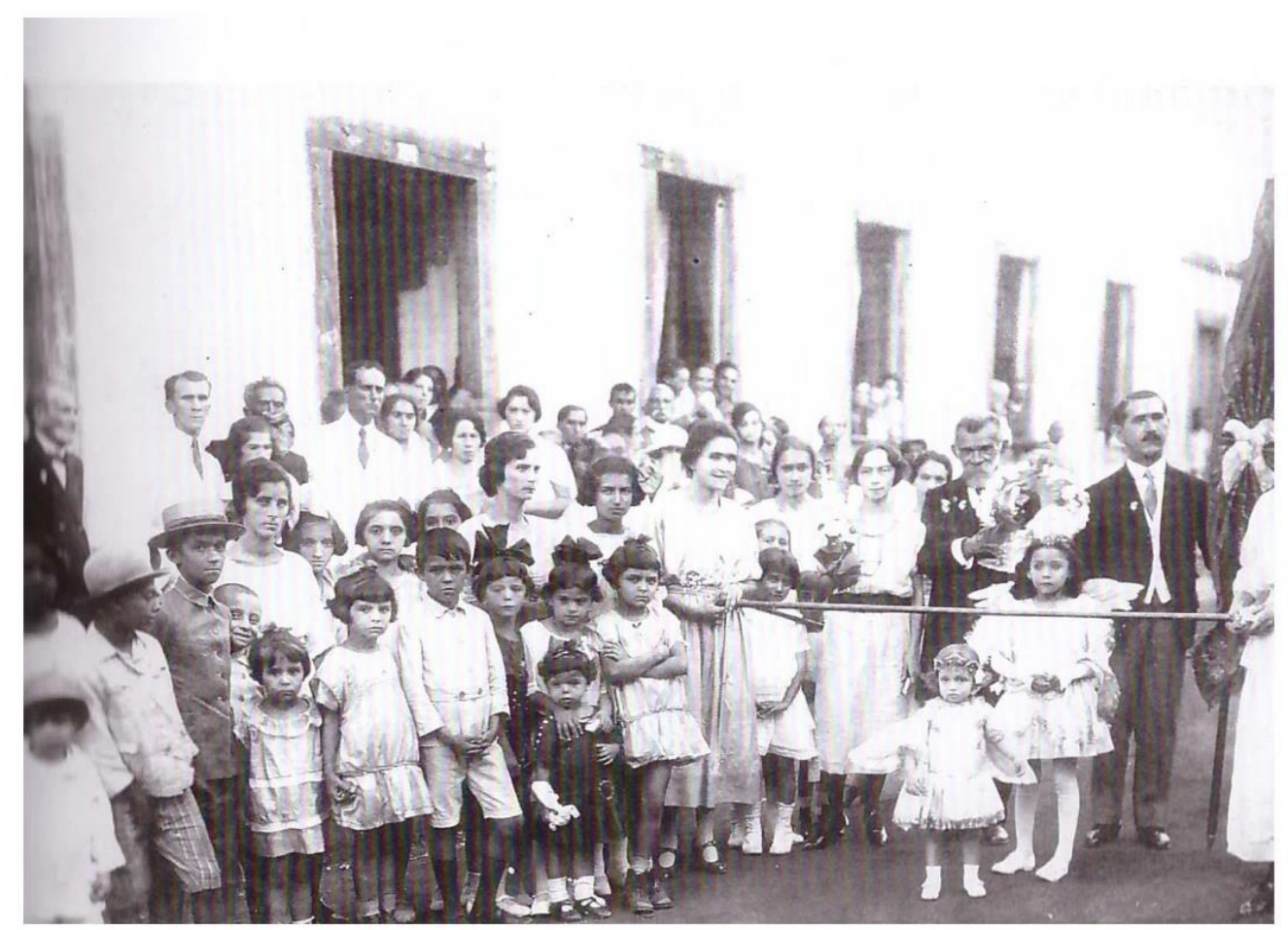

Figura2: festeiros do Divino em Cuiabá, 1919 Fonte: Loureiro , 2006

${ }^{12}$ HOORNAERT, Op. cit., p. 383. 


\subsection{Festa do Divino Espírito Santo, em Cuiabá}

A festa do Divino em Cuiabá, como em diversas regiões brasileiras, nos remete à tradição portuguesa do século IV, quando o Espírito Santo era festejado com banquetes públicos e esmolas aos pobres. Trazida ao Brasil provavelmente por imigrantes açorianos, a festa difundiu-se especialmente durante o Império (época dos primeiros registros na província de Mato Grosso), em função da forte acolhida que tiveram as doutrinas joaquimitas que consideravam aquela época como a do Império do Espírito Santo ${ }^{13}$. Tem sua realização durante o Tempo Pascal, em fins de maio ou começo de junho, terminando no domingo de Pentecostes, quando são eleitos para o ano seguinte o Imperador, Imperatriz, Alferes de Bandeira e demais festeiros devotos do Divino. Pelos registros desta tradição feitos em Cuiabá entre fins do século XIX e início do $\mathrm{XX}$, os eleitos se ocupavam por meses dos preparativos, arcando com as principais despesas dos festejos, sendo representados normalmente por famílias tradicionais e abastadas ${ }^{14}$. A comemoração tinha início no domingo anterior ao de Pentecostes, quando saía em desfile o grupo de cavaleiros fantasiados chamado "Bando do Senhor Divino", tendo à frente um arauto mascarado que recitava versos em tom de chiste, anunciando que era chegado o tempo da festa:

\section{Eu, Sinfronio Simplício Sinforoso \\ Capitão da Briosa, destemido, \\ Tendo fama de bravo e valoroso, \\ Embora viva aqui mesmo e esquecido, \\ Venho agora por parte do Festeiro \\ E por ser dentre os mais, o mais ladino, \\ Anunciar para o povo muito ordeiro \\ Que é chegada a festança do Divino. [...]}

Vinte e um, vinte e dois e vinte e três.

Deste mês que é de todos o primeiro

De maio o mais florido e lindo mês

\footnotetext{
${ }^{13}$ CARVALHO, Maria Michol Pinho de. Divino Espírito (re)ligando Portugal/Brasil no imaginário religioso popular. VI Congresso português de sociologia. Universidade Nova de Lisboa, FCSH, Jun, 2008. Disponível em: <http://www.aps.pt/vicongresso/pdfs/188.pdf> acesso em: 24/11/2014.

${ }^{14}$ LOUREIRO, Op. cit., p. 27.
} 
Sairá da casa do Festeiro,

O bando precatório das esmolas

A percorrer as ruas da cidade,

Levando, muitas moças, sacolas

E velhas com balaios dessa idade! [...]

No dia vinte e quatro quem puder

Não deve então perder essa função...

É uma festa que agrada mais mulher,

Receber uma prenda no leilão.

De ordem do Festeiro podem já

Dispensar a comida da pensão,

Contanto que, no dia, estejam lá,

Rematando umas prendas no leilão. [...]

No dia vinte e sete, finalmente,

Grande missa haverá e procissão

À noite, arrasta pé muito imponente,

Pra rematar de vez esta função.

E agora que já dou por terminado

Minha parte também nesta folia

Vos digo pra frente rapaziada

Vamos pregar em outra freguesia.

Estes versos fazem parte da tradição dos festejos do Divino na Cuiabá da virada do século XIX, reunidos pelo general João Luís Pereira Neto na década de 1920, revelando aspectos da tradição mantidos ao longo dos anos, como a guarda das insígnias, as esmolas, o leilão e a escolha dos festeiros entre as famílias ilustres da cidade $^{15}$. No entanto, algumas mudanças introduzidas na sociedade local refletiram-se nas representações ligadas à festa, a exemplo do "Bando do Divino", anteriormente representado por cavaleiros fantasiados, que foram substituídos na década de 1920

\footnotetext{
${ }^{15}$ MENDONÇA, Rubens de. Roteiro histórico e sentimental da Vila Real do Bom Jesus de Cuiabá. Cuiabá: Igrejinha, 1975, p. 86-7.
} 
por jovens da sociedade que percorriam a cidade anunciando a festa em automóveis decorados (figura 2$)^{16}$.

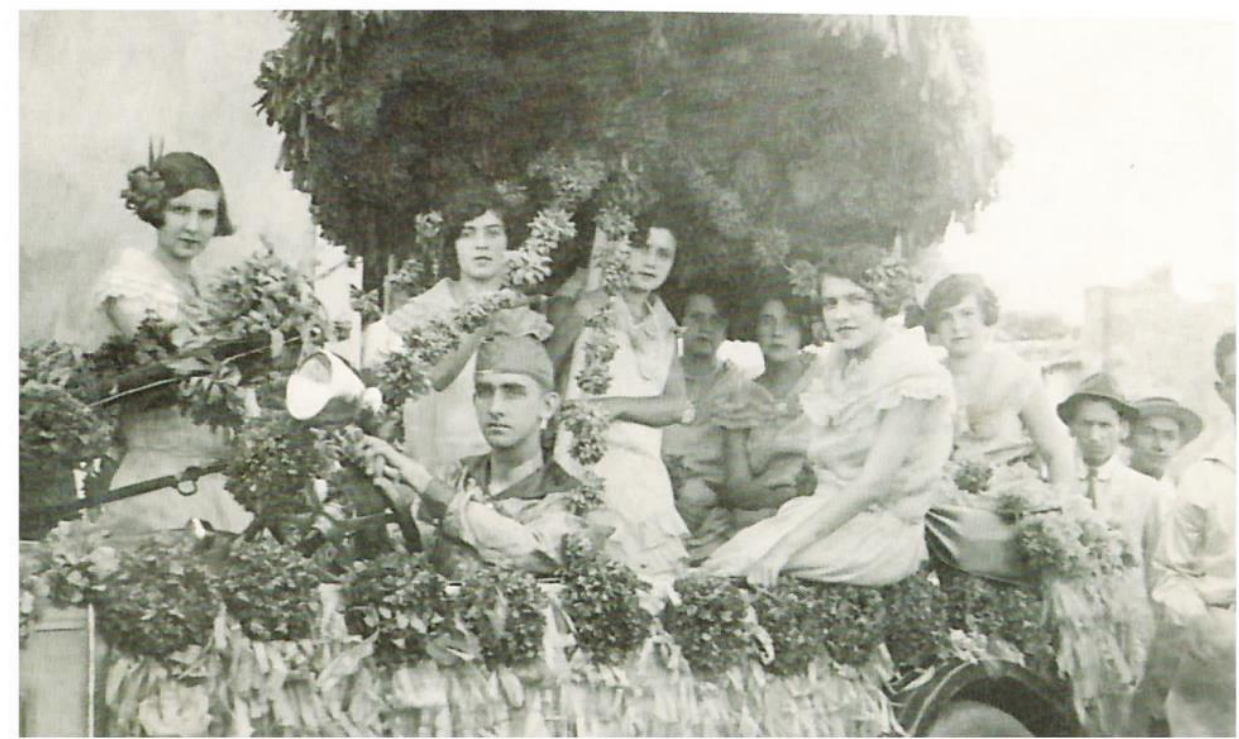

Figura 3: Bando do Divino em 1929

Fonte: Loureiro , 2006

Durante os três dias seguintes ao anúncio, um grande número de fiéis acompanhava em procissão a Bandeira do Divino, com o Imperador e os demais festeiros, à frente, portando as relíquias do Santo e recolhendo esmolas que ajudavam nas despesas da festa. Uma banda militar acompanhava o cortejo executando o hino ao Divino, com rezas, cantorias e breves danças realizadas nas casas visitadas. A comida era também um elemento importante nos festejos, com a famosa distribuição do pãozinho bento do Divino, que simbolizava fartura e prosperidade. A partir do quarto dia, tinha início o tríduo ao Espírito Santo, com missas rezadas na madrugada, subida do mastro enfeitado com a bandeira e as cores do Divino e queima de fogos, com grande participação dos populares. O Imperador também ofertava farta comida aos fiéis em sua casa, onde se montava o altar e se realizava o leilão e o baile do sábado. No domingo de Pentecostes, mais uma procissão percorria a cidade, seguida de missa solene, descida do mastro e banquete na casa do Imperador, onde ainda era oferecido o grande baile de encerramento dos festejos ${ }^{17}$. Nos três dias seguintes ao término dos serviços religiosos, ainda eram oferecidas, sempre às tardes, duas

\footnotetext{
${ }^{16}$ RAMOS, Maria de Lourdes da Silva apud LOUREIRO, Op. cit., p. 31.

${ }^{17}$ Ibidem, p. 27-32.
} 
modalidades de diversão ao ar livre: as cavalhadas e as touradas realizadas na Praça da Matriz e no antigo Campo d'Ourique ${ }^{18}$.

Os festejos do Divino em Cuiabá tornaram-se, conforme o que já foi dito, uma manifestação da elite mato-grossense, mesmo contando com uma significativa participação popular em alguns dos seus eventos. Este perfil elitista não inibiu, segundo Loureiro, que as camadas mais pobres da sociedade cuiabana também organizassem suas próprias diversões, determinando alguns outros formatos para a mesma data ${ }^{19}$. É provável que venha destes espaços reservados ao populacho o costume ainda mantido da celebração do Divino em residências de bairros antigos, como a função de Cururu registrada em 2011 por Gushiken, em festa da família de Maria Lorin no bairro Don Aquino (figura 4) 20.

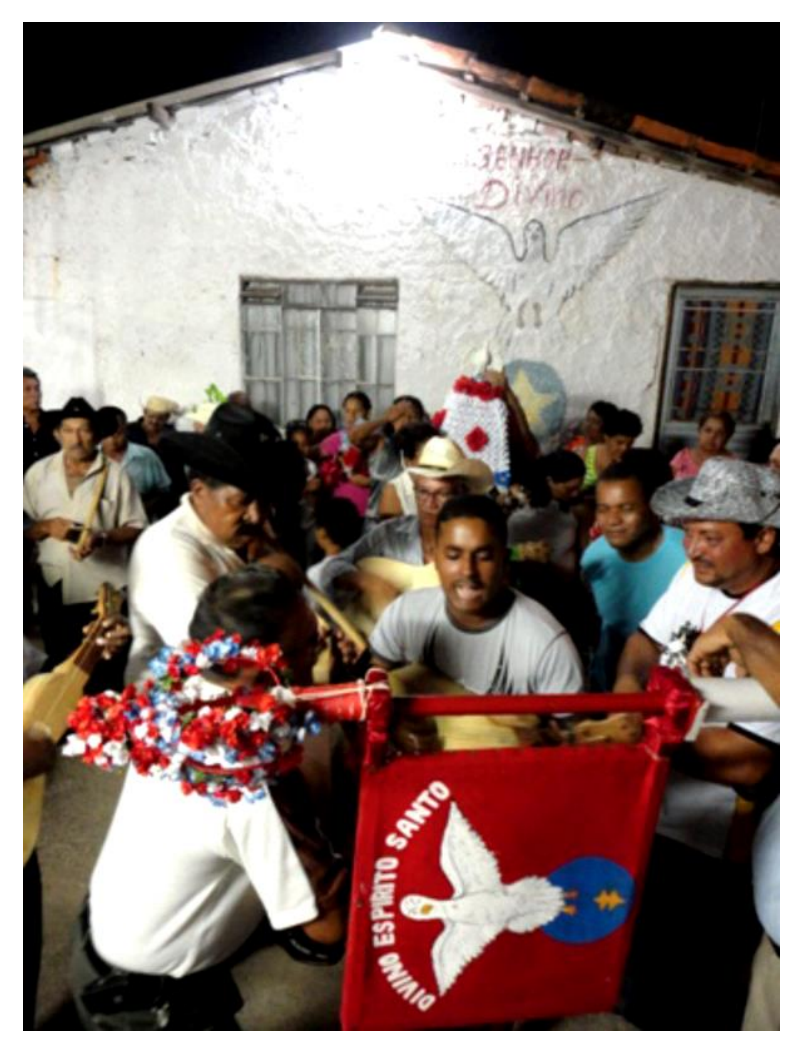

Figura 4: Cururu na festa do Divino Espírito Santo Fonte: Gushiken, 2012

\footnotetext{
${ }^{18}$ MENDES, Francisco Alexandre Ferreira. Lendas e tradições cuiabanas. Cuiabá: FCMT, 1977, p. 94-6. ${ }^{19}$ LOUREIRO, Op. cit., p. 32.

${ }^{20}$ GUSHIKEN, Yuri. Mapa das festas de santos da grande Cuiabá e interlândias. Anuário da Cátedra Unesco/Metodista de Comunicação para o Desenvolvimento Regional. Universidade Metodista de São Paulo Ano 16, no. 16, p. 47-66, jan/dez 2012, p. 59.
} 
Do outro lado, o caráter predominantemente pomposo da festa pôde ser ainda percebido nas celebrações programadas pela arquidiocese de Cuiabá para o ano de 2013. Neste ano a festa do Divino iniciou com missa presidida pelo cura da Catedral Basílica de Cuiabá, seguida da entrega das insígnias ao Imperador e levantamento da bandeira do Divino, ao som da banda da Polícia Militar. E na manhã seguinte, o então prefeito Mauro Mendes e a primeira dama do município Virgínia Mendes recepcionaram a Bandeira do Divino e seus devotos para mais uma missa solene na mesma basílica (figura 5).

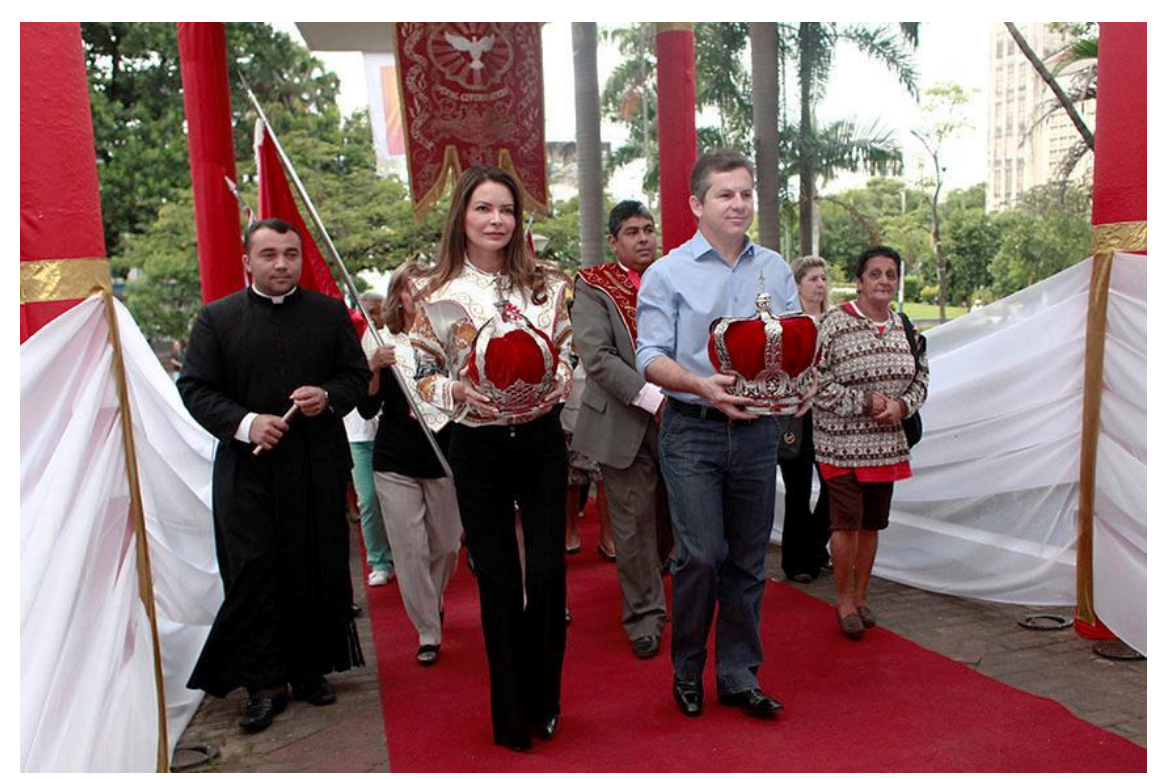

Figura 5: Festa do Divino Espírito Santo

Fonte: Arquidiocese de Cuiabá, 2013

\subsection{Festa de São Benedito, em Cuiabá}

A festa de São Benedito da paróquia de Nossa Senhora do Rosário e São Benedito, comemorada entre os meses de julho e agosto, é hoje a festa de santo de maior público na cidade, sobrepujando inclusive o culto ao padroeiro do município, o Senhor Bom Jesus. Isto porque, além dos eventos tradicionais que iniciam na primeira madrugada (a subida do mastro da bandeira do santo, as missas às cinco da manhã seguidas de chá com bolo, as procissões e o foguetório), são programadas ao longo dos quatro dias de festa algumas atrações do entretenimento de massa. 0 pátio e as ruas ao redor da igreja são tomados ao final da tarde pelo público e por vendedores a oferecer em suas barracas imagens do santo e souvenires em geral, além de comidas 
típicas da região e bebidas industrializadas. Os pratos da feira gastronômica e os shows musicais de grupos folclóricos e nomes do circuito comercial local, realizados em um grande palco montado pela prefeitura e o principal canal de televisão da região, são bastante concorridos, extrapolando assim o seu caráter original de celebração desta ou daquela determinada comunidade. É justamente esta cada vez mais comum interação do popular com os meios massivos, com a promoção do turismo e com os atos das políticas culturais que faz Canclini ressaltar os diferentes posicionamentos em cena dos seus atores como modos dinâmicos de afirmação das tradições. Já não mais exclusivos de determinados grupos étnicos ou religiosos, estes fenômenos são hoje o produto de uma economia dinâmica e uma cultura interativa e multideterminada por "agentes populares e hegemônicos, rurais e urbanos, locais, nacionais e transnacionais". ${ }^{21}$

Em Cuiabá, a devoção a São Benedito inicia com a construção de uma capela para o santo na Rua do Sebo, em 1722, pelos escravos trazidos para os trabalhos das minas do Sutil. Esta capela acabou ruindo em pouco tempo e o culto dos negros foi transferido para uma anexa à Igreja de Nossa Senhora do Rosário, em meados do século XVIII, na margem esquerda do córrego da Prainha (figura 6). Já nesta época, a Irmandade do Glorioso São Benedito passa a ocupar o mesmo templo da Irmandade de Nossa Senhora do Rosário, a exemplo de congregações afins em outras localidades brasileiras. É o que indica o auto de partilha de uma jazida de ouro destinada a ambas as ordens, no ano de 1747, demonstrando que as mesmas eram próximas entre si já na época de sua formação ${ }^{22}$. Através do seu estatuto ou compromisso de 1867 , o terceiro das três edições aprovadas ao longo da história da Irmandade de São Benedito de Cuiabá, é possível aferir o tipo de controle a que estavam submetidas as confrarias católicas dos homens pretos e pardos. Para serem aceitos, estes membros deveriam professar a crença católica, "não ter crimes e vícios" e não podiam estar "filiados a algumas das seitas condenadas pela Igreja Católica". Mesmo com estas ressalvas, havia certa liberdade na manifestação das tradições africanas e no desenvolvimento de práticas religiosas sincréticas no seio destas ordens, uma vez que

\footnotetext{
${ }^{21}$ CANCLINI, Néstor García. Culturas híbridas: estratégias para entrar e sair da modernidade. São Paulo: Edusp, 2013, p. 220.

${ }^{22}$ MENDES, Marcos Amaral. Devoção e território: a Irmandade de São Benedito em Cuiabá (1722-1897). Território e Fronteiras - ICHS/UFMT V. 4 N.1 - Jun/Jul 2011, 84-108, p. 88.
} 
a figura do Rei e da Rainha negros e a dança do Congo praticada pelos seus devotos eram destaques nas festas antigas da Irmandade em Cuiabá. Além disso, o compromisso de 1865 instituía uma Caixa Pia destinada, entre outros fins, a "coadjuvar a alforria de seus Irmãos cativos", embora não haja notícia de intervenções desse tipo na história da Irmandade 23.

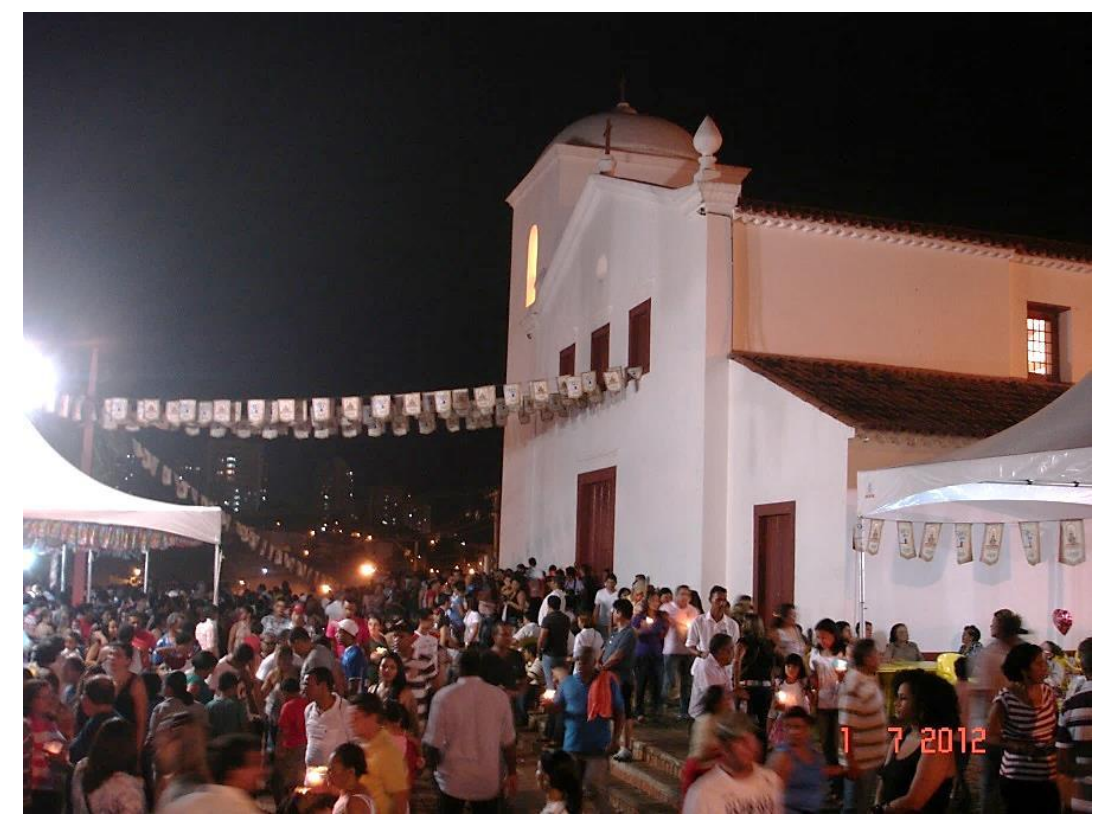

Figura 6: Igreja N. S. do Rosário na Festa de São Benedito em Cuiabá Fonte: o autor, 2012

Nas comemorações de São Benedito de 2012, o Cururu e o Siriri foram representados no formato dos espetáculos públicos de música e dança, com os seus músicos e bailarinos dispostos no palco montado próximo ao adro da igreja e à frente dele. Foi assim com o prestigiado grupo Flor Ribeirinha, da comunidade de pescadores e artesãos São Gonçalo Beira Rio, que apresentou variadas coreografias a partir de canções próprias e da tradição. Ao contrário do que sugere a tradição ribeirinha, não se viu na principal festa cuiabana a São Benedito, em frente ao altar e ao mastro, o Cururu cantado e dançado em louvor ao santo. Nem se soube de baile algum animado pelo Siriri, na voz e nos instrumentos dos mesmos cantadores. Porém, o público foi brindado com os passos e os figurinos do Grupo Flor Ribeirinha, realçados pelo jogo de luz e movimento criado pelos seus coreógrafos e cenógrafos.

\footnotetext{
${ }^{23}$ Ibidem, p. 91-3.
} 


\subsection{Outras festas de santos populares}

Por serem espaços onde mais comumente se consagram práticas autônomas de devoção popular, as festas juninas em homenagem a Santo Antônio, São João e São Pedro revelam um sem-número de peculiaridades, se as compararmos às festas organizadas pelas paróquias ou irmandades. Tradicionalmente realizados nas casas das famílias e com pouca participação da Igreja, estes festejos expressam através de suas obrigações e diversões alguns dos saberes religiosos mais antigos em suas comunidades. São também comuns deste período os cultos a São Gonçalo e a Sant'Ana, celebrados em junho e julho, respectivamente. Estes festejos são geralmente extensivos ao seu meio - com a casa dos festeiros aberta não só aos moradores do bairro, como também a toda cidade - e têm sua origem na devoção antiga de um clã ao seu santo, motivada muitas vezes pelas promessas feitas em razão de uma determinada graça alcançada. Em Mato Grosso, tais celebrações podem ocorrer tanto nos dias consagrados ao orago quanto em dias posteriores, podendo o período se estender até meados de agosto. Também é comum a homenagem a mais de um santo de devoção da família na mesma data, como no caso da festa dedicada a São João e São Gonçalo que presenciei na casa de Dona Apolônia de Siqueira, em junho de 2012 na cidade de Poconé.

A festa oferecida pela família de Dona Apolônia tem a duração de três dias, sem contarmos aqueles envolvendo a sua preparação. Na ocasião de minha visita, a organização geral estava a cargo de seu neto, Robert de Siqueira, e contava com a dedicação de quatro gerações da família, entre filhos, netos e bisnetos. Uma tradição que perdura a mais de 50 anos, tendo sido iniciada pela mãe de Dona Apolônia, que esteve à frente das festividades por mais de 25 anos seguidos. A razão de tanto empenho da família em abrir as portas de sua casa a toda a cidade e em oferecer a festa a milhares de devotos é o sentimento de caridade e devoção inspirados por ela e sua progenitora, ambas mães-de-santo e devotas de São João e São Gonçalo ${ }^{24}$. 0 antropólogo Carlos Rodrigues Brandão observa que a memória do saber da religião popular se preserva quando estão "ativas as condições do trabalho coletivo dos especialistas do sagrado" e a transmissão desse saber, ou seja, “a guarda dessa

\footnotetext{
${ }^{24}$ Parte das informações sobre festa da família Siqueira foi obtida em entrevista com o Sr. Gonçalo Siqueira, filho de Dona Apolônia, realizada pelo autor em 20/06/2012. Ver também LOUREIRO Op. cit., p. 45.
} 
memória" se dá no exercício constante da sua função, com os mais moços ajudando no trabalho dos velhos ${ }^{25}$. Porém, esta estrutura de transmissão revela-se frágil, mesmo contando com o auxílio dos elos de família, uma vez que ela depende da atividade contínua e da sobrevida da pequena ordem social que a mantém ${ }^{26}$. Em 2012, a festa contou com o esmero de grande número de devotos, tendo a frente os netos e filhos de Dona Apolônia, empenhados em seguir a sua orientação.

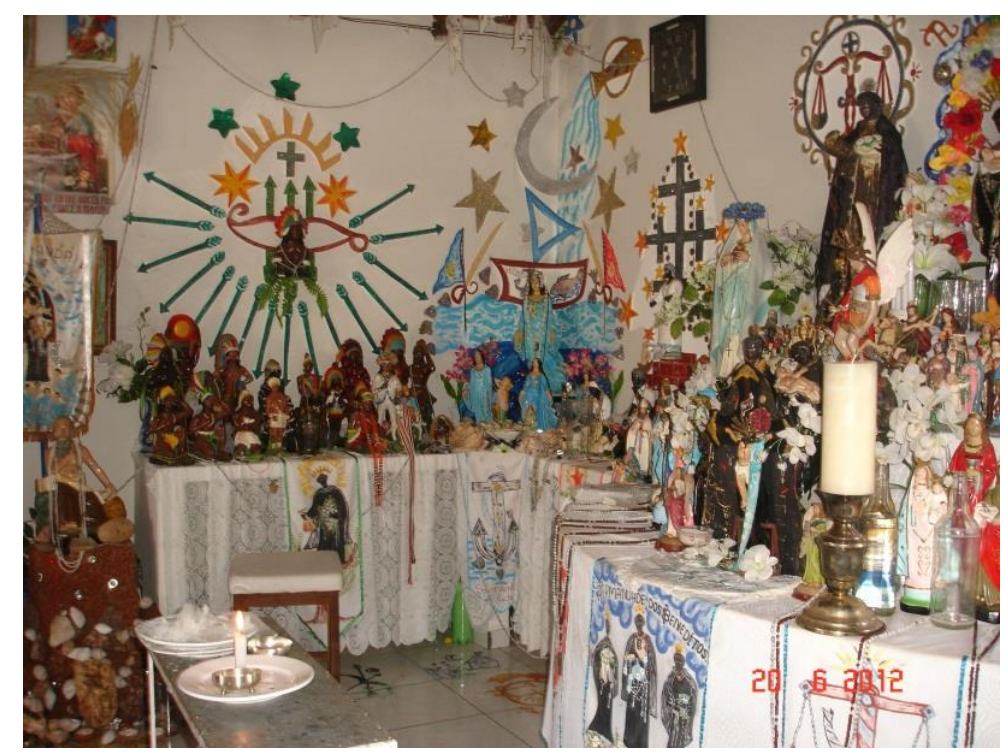

Figura 7: Sala das imagens, residência de Dona Apolônia em Poconé Fonte: o autor, 2012

Nos dias de véspera, da quarta até a sexta-feira, o portão da casa esteve constantemente aberto. A sala das imagens dos santos e divindades africanas foi arrumada e encheu-se de saquinhos de biscoitos preparados pelas cozinheiras e ofertados a todos os devotos; toda a área externa foi decorada e refeições fartas foram oferecidas nestes dias a todos os presentes, sem a cobrança sequer de um centavo pela comida. A festa teve início na sexta-feira à noite com reza e cantoria em frente ao altar, seguida de procissão com velas até a Igreja Matriz, acompanhada de músicos da banda e foguetório. Terminada a procissão, ocorreu a cerimônia de subida do mastro, momento em que normalmente os cururueiros louvam os santos. Naquele ano, o Sr. Robert de Siqueira, neto de Dona Apolônia, decidira que não haveria o Cururu na subida do mastro "pra não ficar muito comprido". Fiquei um tanto

\footnotetext{
${ }^{25}$ BRANDÃO, Os deuses do povo. Op. cit., p. 303-6.

${ }^{26}$ Ibidem, p. 308.
} 
decepcionado por não ouvir os cantadores e violeiros naquele momento, uma vez que permaneceria apenas aquela noite em Poconé, e pensei que aquele poderia ser um indício da perda, descrita por Brandão, de uma parte da rede de transmissão do saber religioso. Mas a festa prosseguiu com o baile de Rasqueado madrugada adentro, após os convidados se servirem do jantar oferecido. Já no sábado, os cantadores puderam brincar o Cururu, louvando os santos em frente ao altar e seguindo a procissão. E no domingo brincaram também a dança de São Gonçalo.

Para que tenhamos uma melhor noção das permanências e mudanças nos costumes que caracterizam as festas religiosas ao longo de um tempo mais recente, julgo interessante mencionar a experiência vivida pela historiadora Eunice Ajala Rocha, observando os cururueiros na cidade de Corumbá, Mato Grosso do Sul, durante os festejos de Sant'Ana, entre 1977 e 1979. Segundo a pesquisadora, o culto à Sant'Ana era considerado àquela época o festejo mais tradicional da cidade, havendo notícias de sua celebração por cerca de 50 anos ininterruptos ${ }^{27}$. A festa observada durava uma semana inteira, tendo o seu início na madrugada do sábado anterior a 26 de julho, o dia oficialmente dedicado à santa. Era quando o capitão do mastro, os cururueiros e fiéis traziam o mastro para o local das celebrações. Na noite de abertura, os cantadores postavam-se em frente ao altar e pediam licença para cantar em homenagem os donos da casa e à santa, enquanto aguardavam a capelã, que era leiga, dizer suas primeiras rezas em latim. Em seguida, era organizada uma procissão até o local da subida do mastro, na esquina próxima à casa dos festeiros, com todos os devotos portando velas e entoando cânticos em louvor à santa ${ }^{28}$. Assim a festa prosseguia com muita reza, ladainha e cantoria, além da diversão garantida pela comida e os arrasta-pés que se estendiam por toda a semana até o encerramento, com a descida do mastro e a escolha dos festeiros para o próximo ano. Um dos aspectos mais relevantes na descrição feita por Eunice Ajala Rocha há mais de 25 anos é a presença constante dos cururueiros, cumprindo suas "obrigações" com a santa e também promovendo a "diversão". As funções de Cururu, que já não eram mais uma prática contínua como nas festas de antigamente, continuavam ainda assim

\footnotetext{
${ }^{27}$ ROCHA, Eunice Ajala. Uma expressão do folclore mato-grossense: Cururu em Corumbá. Dissertação de mestrado em história. Porto Alegre: PUCRS/IFCH, 1981, p. 71.

${ }^{28}$ Ibidem, p. 72-5.
} 
como um elemento de destaque na festa de Sant'Ana, com seus cantadores de tudo cuidando, inclusive convidando cada um dos presentes "a rezar, a beijar a bandeira, a pagar as promessas". ${ }^{29}$ Com a crescente interferência das ações voltadas para o turismo e as mudanças nos costumes ligados ao lazer festivo, o papel evangelizador do Cururu cedeu espaço para o seu cultivo sobretudo no âmbito das mostras de folclore.

Mesmo com os fatos apontando para um declínio da participação dos cantadores nas práticas religiosas do lugar, é grande ainda o prestígio do cururueiro que preserva a habilidade de cantar na letra (segundo a Escritura). Nas festas de santos cujas tradições ainda são mantidas pelas irmandades locais ou pelas antigas famílias, estes renomados cururueiros são chamados a tomar parte nas celebrações, sendo recebidos com grande deferência pelos festeiros. A cada um dos cantadores convidados cabe saudar os santos, os donos da casa e convidar a todos, sempre cantando, para as rezas, a formação da procissão e o levantamento do mastro. Durante todas as etapas é dada aos devotos a oportunidade de ouvir, por intermédio da cantoria, diversas passagens da Bíblia, como a que ouvi de "Seo" Gonçalo de Santo Antônio de Leverger, em agosto de 2014, narrando a cena da escada avistada em sonho pelo patriarca Jacó (exemplo 1, faixa 6 do CD em anexo). Nesta cena, depois de fugir a um confronto com o seu irmão Esaú, motivado pela traição engendrada por sua mãe Rebeca que disfarçou o filho para que recebesse a benção do seu pai Abraão, Jacó vislumbra em sonho uma escada que ia da terra aos céus, onde anjos subiam e desciam continuamente através dela ${ }^{30}$.

Era uma noite d'onde, n'ela,

Jacó inventou para ser disfarçado.

Sonhou com uma grande escada,

Que tinha grande mistério.

Era uma turma de anjos,

Lá ia da terra para o céu.

\footnotetext{
${ }^{29}$ Ibidem, p. 75-6.

${ }^{30}$ Genesis, 28: 10-19. A Bíblia Sagrada. São Paulo: Sociedade Bíblica do Brasil, 1978, p.31-2.
} 
A Fátima te levava,

Ia no trono até Daniel.

Oh, Deus , Pai Eterno!

Oi, lai, lai, lai, lai, lai...
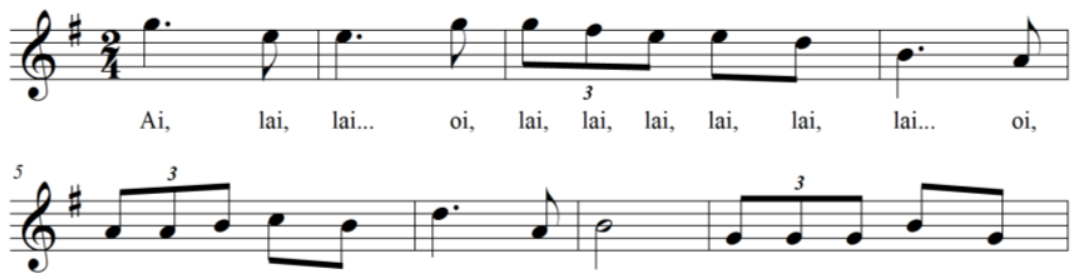

lai, lai, lai, lai, lai, lai, oi, ai... E - ra - ma noi - te on -

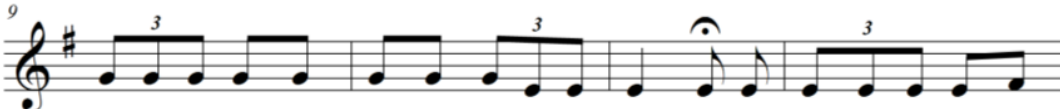

de e-la in-ven - tou pa - ra ser dis-far - ça - do. So-nhou com u - ma es -
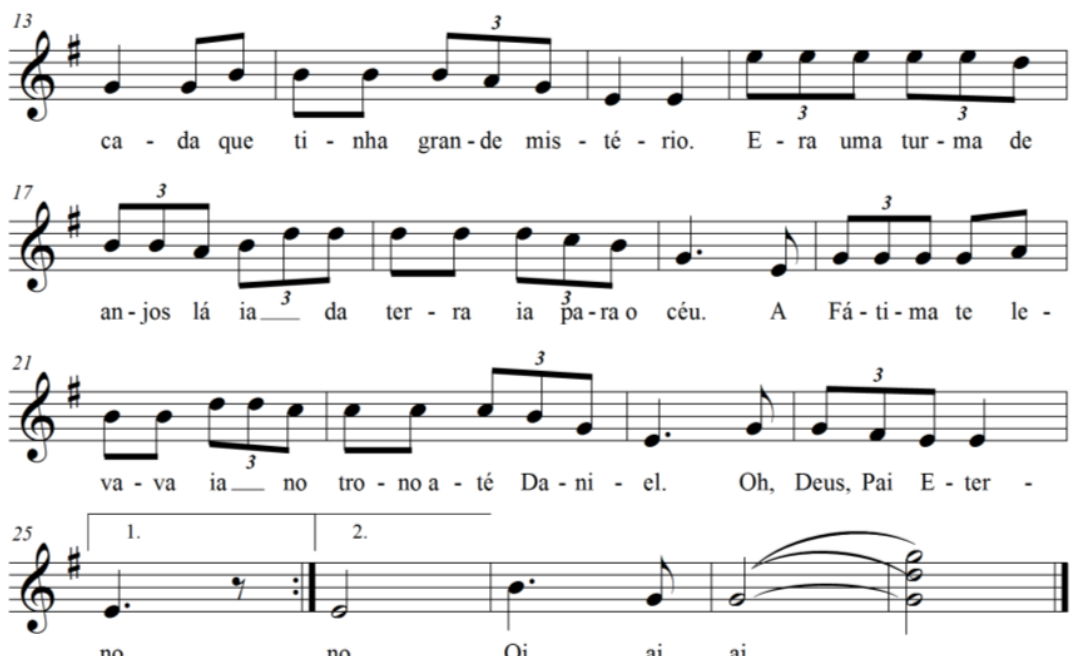

$\mathrm{Oi}$

Exemplo 1: Toada de Cururu ("Seo" Gonçalo de Sto. A. Leverger) Fonte: o autor

Em outra toada, o Sr. Euclides Maia da Silva, cururueiro de Cuiabá, narra de modo singelo a visita de Maria Madalena ao túmulo de Jesus, sepultado no Monte Calvário a mando de José de Arimatéia (exemplo 2, faixa 7 do $\mathrm{CD}$ em anexo). Na descrição, Maria Madalena ficara "aborrecida" ao encontrar o sepulcro vazio, sem saber ainda que Jesus havia ressuscitado ${ }^{31}$.

\footnotetext{
${ }^{31}$ Evangelho de João, 19: 38-42 e 20: 1-19. Op. cit., p. 148-50. Esta toada de Cururu foi recolhida por Elisabeth Travassos e Roberto Corrêa em 1988 e transcrita por Edilberto Fonseca em 2009. In VIANNA, Letícia (org.). Dossiê Iphan 8: modo de fazer viola-de-cocho. Brasília: Minc/Iphan, 2009, p. 89.
} 
Oi, ai, ai...

Deus te salve, casa santa

Oi, ai, ai...

Onde Deus fez a morada

Meu Jesus quando morreu

Chegou Santa Madalena

Para visitar o túmulo

Onde estava a sepultura

Ficou borrecida

Chegou em Monte Calvário.
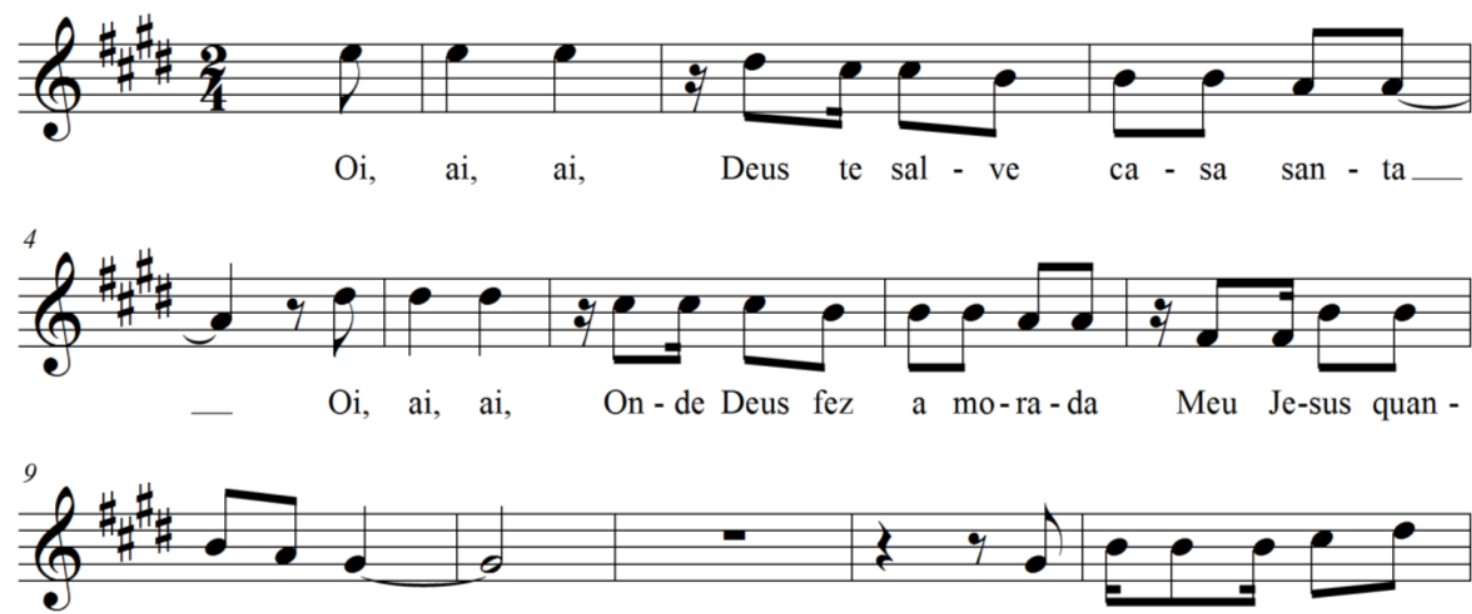

do mor - reu

Che - gou San - ta Ma - da -
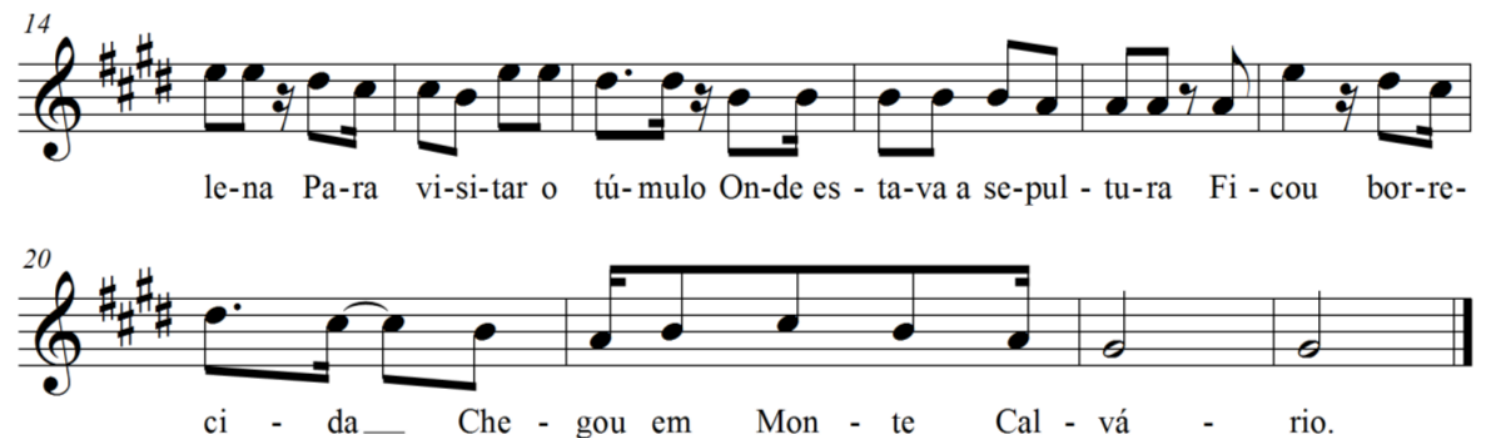

Exemplo 2: Toada de Cururu, de Cuiabá

(Sr. Euclides Maia da Silva e outros)

Fonte: Travassos, Corrêa e Fonseca, 2009 
No ano de 2011, participei de uma festa em homenagem a São João na casa de Dona Felipa e Seu Odair, no bairro Jardim Araçá, em Cuiabá. A família conserva por anos o gosto pelas festas juninas, em especial no dia 24 de julho, a data em que é também comemorado o aniversário do filho João Felipe, preparando com esmero os pratos típicos para o jantar, os licores e os doces, além de conservar outros hábitos antigos da família, como a reza para o santo, a procissão pelas ruas das imediações da residência e a "lavagem do santo". Este ritual consiste em levar à agua uma imagem do santo, simbolizando o batismo praticado por João Batista na conversão dos judeus. Um simbolismo desdobrado pela religião popular em variadas simpatias, como, por exemplo, a de atar o pedestal da imagem a um cordão e mergulhá-la de ponta-cabeça em uma botija ou bacia d'água para que o devoto, no o ato de "judiar do santo", o instigue a atender seus pedidos. Steinen reproduz em sua segunda crônica sobre Cuiabá, no final do século XIX, uma carta pastoral de 27 de maio de 1888 em que o bispo D. Carlos de Cuiabá condena, "com palavras severas", o costume de se "lavar" o santo. Dizia o clérigo que, na véspera do dia em homenagem a São João,

[...] pequenas imagens são levadas, com verdadeira palhaçada aos rios, às fontes, e mesmo à torneira, onde são mergulhadas na água com acompanhamento de cantos e música e tudo isso com a convicção de estarem praticando atos piedosos; no dia seguinte levam-se as imagens à igreja, onde são colocadas no altar durante a missa. [Este] abuso extremo deve ser removido por [ser] intolerável ${ }^{32}$.

Steinen observa, no entanto, que a censura das autoridades da Igreja à "lavagem" do santo não era coerente com a tolerância dos clérigos a outras práticas supersticiosas, como o pagamento de promessas de curas firmadas junto aos santos pelos mesmos devotos 33 .

Mais um detalhe da comemoração de São João, no Jardim Araçá em Cuiabá: um cardápio primoroso foi servido (com delícias como o sarapatel e maria isabel com farofa de banana; doces de caju, banana e casca de limão; furrundu, maria-mole e goiabada), todos os presentes rezaram e saíram em procissão, "lavou-se" a imagem do santo, mas não havia o cururu animando a festa.

\footnotetext{
${ }^{32}$ STEINEN, Karl von den. Entre os aborígenes do Brasil Central. São Paulo: Dep. de Cultura, 1940, p. 712.

${ }^{33}$ Idem.
} 


\section{NO BRASIL COLONIAL}

Além de instrumentos de afirmação da hegemonia política e espiritual da Metrópole, as celebrações de caráter comunitário no Brasil dos séculos XVII, XVII e XVIII visavam, segundo Tinhorão, ordenar o tempo das pessoas, através de um extenso e pomposo calendário cívico-religioso, para que fossem erradicados costumes considerados detestáveis pelas autoridades. Sendo o colono português em número bem menor que o de nativos, africanos e mestiços, havia a premência de se conter os arroubos contrários à disciplina imposta pela catequese, de preferência sem que se fizesse concessão alguma à cultura original desses grupos ${ }^{34}$. Mas esta não era uma preocupação da Igreja apenas nas regiões colonizadas, onde a cristandade deveria se difundir seguindo os preceitos do Concílio de Trento; na Europa recémsaída da Idade Média também se buscava conter a herança pagã nas festas, através de uma reforma da cultura popular.

Peter Burke nos mostra que a reforma encabeçada pela Igreja na Europa do início da Idade Moderna teve a festa, no contexto da cultura popular europeia tradicional, como uma de suas principais preocupações, com os reformadores investindo contra uma longa lista de manifestações da cultura secular - incluindo certas danças, baladas, jogos, contos, máscaras, baladas, charivari, magias e adivinhações ${ }^{35}$. Nas comemorações das famílias ou nas das comunidades (como a dos santos padroeiros dos povoados) e nas festas anuais comuns à maioria dos europeus (a Páscoa, o Solstício de Verão e o Carnaval, entre outras), as pessoas deixavam de lado o trabalho e se entregavam por vários dias à diversão. Era a ocasião em que exibiam suas melhores roupas e consumiam toda a bebida e a comida que havia, contrapondo-se a um cotidiano de "cuidadosa economia." 360 aproveitamento de celebrações pagãs no calendário cristão era uma estratégia adotada desde o início da difusão da doutrina pela Europa, mas era ainda preciso insistir na transformação do seu sentido original, de um lado orientando o tempo para o cultivo da fé e de outro permitindo um pouco de alívio na rotina de penitências a que as pessoas estavam

\footnotetext{
${ }^{34}$ TINHORÃO, José Ramos. As festas no Brasil colonial. São Paulo: Ed. 34, 2000, p. 7.

${ }^{35}$ BURKE, Peter. Cultura popular na Idade Moderna: Europa 1500-1800. São Paulo: Cia das Letras, 2010, p. 281.

${ }^{36}$ Ibidem, p. 243.
} 
submetidas. E mesmo tendo o clero obtido resultados a seu favor, alguns dos impulsos dionisíacos herdados do mundo antigo acabaram por permanecer nas práticas festivas da Europa, sobretudo nas regiões mais próximas ao Mediterrâneo, conforme demonstra a reação dos bispos da região do Languedoc, que até mesmo no final do século XVII expressavam

[...] seu horror a charivari violentos, danças indecentes em dias de festa, adivinhos, atores ambulantes e uma ignorância generalizada sobre a religião, [...] precisando proibir seus párocos de frequentar peças, danças e mascaradas, como se a reforma nunca tivesse acontecido ${ }^{37}$.

As condições que envolviam o zelo pela fé católica no Brasil colonial também estavam aquém das expectativas do clero, não só por ter o ambiente descrito por Burke sido provavelmente o mesmo do colono português antes de sua chegada às novas terras, como também devido à influência contrária dos costumes e das práticas rituais dos povos nativos e dos escravos trazidos do continente africano. Para o padre José de Anchieta, havia uma predisposição geral à indolência e aos excessos mundanos por parte dos primeiros moradores dos povoados brasileiros, sobretudo em virtude do clima dos trópicos e do convívio com o gentio.

É terra desleixada e remissa e algo melancólica e por esta razão os escravos e os Índios trabalham pouco e os Portugueses quase nada e tudo se leva em festas, convívios e cantares, etc., e uns e outros são mui dados a vinhos e facilmente se tomam deles e os Portugueses não o têm por afronta e desonra e os convívios que se dão nesta terra, além de serem muito ordinários, são de grande custo e neles se fazem muitos excessos de comeres esquisitos, etc. ${ }^{38}$

Outro cronista que, ao relatar as dificuldades enfrentadas na primeira missão jesuítica da América, acabou por produzir uma rica etnologia dos povos locais foi o padre Manuel da Nóbrega. Em carta de 1549, endereçada ao seu mestre na Universidade de Coimbra, Martinho de Aspilcueta Navarro, Nóbrega dizia-se

\footnotetext{
${ }^{37}$ Ibidem, p. 314-5.

${ }^{38}$ ANCHIETA, José de. Informação da Província do Brasil para nosso Padre [1585] in Cartas, informações, fragmentos históricos e sermões (1554-1584). Rio de Janeiro: Civilização Brasileira, 1931, p. 245.
} 
admirado por ter Deus destinado, até então, terra como aquela, com tamanha riqueza e vastidão, a seres que se encontravam em completo estado de barbárie. E dentre os "apetites sensuais" que regiam aquelas vidas, o missionário apontava a poligamia e o adultério como algumas de suas piores inclinações, assim como o "ódio cordial" devotado aos inimigos de guerra, que os levava a tratar como iguais os prisioneiros a serem canibalizados ${ }^{39}$. No entanto, reconhecia o missivista que, ao lado de toda a distância existente entre os costumes dos índios e o mundo cristão, muitos eram os curumins a demonstrar interesse no caminho proposto pela catequese:

Onde quer que vamos somos recebidos com grande boa vontade, principalmente pelos meninos aos quais ensinamos. Muitos já fazem as orações e as ensinam aos outros. [...] E alguns vêm pelos caminhos a nosso encontro, perguntando-nos quando havemos de batizar, mostrando grande desejo e prometendo viver conforme o que lhes aconselhamos. [...] Outra vez descobriu o Padre [João de Aspilcueta] em uma aldeia, que cozinhavam o filho de um inimigo, a fim de comerem-no: e porque fossem repreendidos, soubemos mais tarde que o enterraram e não o quiseram comer ${ }^{40}$.

Em mesma carta, Nóbrega também lamentava o número reduzido de sacerdotes em tão vasto território, reconhecendo estar a sua missão junto aos nativos sempre em falta com o número imenso de catecúmenos que morriam antes mesmo de terem suas almas consideradas salvas pelo batismo.

De muitas partes somos chamados, para irmos ensinar as coisas de Deus e não podemos chegar, porque somos poucos, e certo, creio que em todo o mundo não se nos depara terra tão disposta para produzir o fruto como esta, onde vemos almas perecerem por se não poder remediá-las: em falta, vamos lhes acendendo a vontade de ser cristãos, para que se morrerem, neste comenos, enquanto dura o catecismo, deles Deus haja misericórdia ${ }^{41}$.

Esta carência de catequistas fazia com que os novos devotos, já no início da formação do Brasil, buscassem alternativas criativas para os ritos ensinados pelos

\footnotetext{
${ }^{39}$ NOBREGA, Manuel da. Cartas do Brasil (1549-1560). Rio de Janeiro: Officina Industrial Graphica, 1931, p. 90.

${ }^{40}$ Ibidem, p. 92.

${ }^{41}$ Ibidem, p. 93-4.
} 
jesuítas, como no caso ocorrido em uma aldeia da Bahia, em 1584, por ocasião do Dia de Cinzas, no início da Quaresma. Contou o padre visitador Fernão Cardim que os índios daquela aldeia chegavam de longe para a cerimônia em que o sacerdote traçava uma cruz na fronte de cada fiel, utilizando as cinzas úmidas em água benta provenientes da queima dos ramos abençoados no Domingo de Ramos. E assim, na ausência do padre celebrante, os mesmos se encarregavam de proceder ao ritual, conforme nos informa Cardim:

[...] do cabo do mundo vêm [os índios] à cinza, e folgam que lhes ponham grande cruz na testa, e se acontece o padre não ir às aldeias, por não ficarem sem cinza eles a dão uns aos outros, como aconteceu a uma velha que, faltando o padre, convocou toda a aldeia à igreja $\mathrm{e}$ lhes deu a cinza, dizendo que assim faziam os Abaés [padres], e que não haviam de ficar em tal solenidade sem cinza ${ }^{42}$.

0 episódio acima descrito ilustra a presença, já nos primeiros anos da implantação do catolicismo no Brasil, de alguns dos elementos que mais caracterizaram as práticas de religiosidade popular ao longo dos períodos seguintes: certa autonomia dos devotos em relação a um poder eclesial central e a reelaboração de suas tradições em virtude do isolamento das regiões. Outro aspecto revelado nestas práticas pioneiras é seu o caráter teatral, presente em procissões como a do Corpo de Cristo e a festa de Santa Úrsula e as Onze Mil Virgens, além dos autos representados nas festas religiosas, que muito agradavam aos índios ${ }^{43}$. Fernão

\footnotetext{
${ }^{42}$ CARDIM, Fernão. Tratados da terra e gente do Brasil [1584?]. São Paulo: Cia Ed. Nacional, 1978, p. 191.

${ }^{43}$ A devoção a Santa Úrsula e as Onze Mil Virgens, hoje pouco conhecida, foi difundida no início da Idade Moderna na Europa católica e suas colônias. Segundo a lenda, Santa Úrsula viveu por volta do século IV ou $\checkmark$ e era filha de um rei bretão. Antes de casar-se, peregrinou pela Europa acompanhada de onze mil moças virgens, tendo sido capturadas e decapitadas pelos bárbaros hunos, perto dos muros da cidade de Colônia. A única virgem poupada da chacina foi a princesa Úrsula que, diante da recusa em se casar com o rei huno, acabou morta em seguida. Ossadas encontradas na região onde acreditou-se ter havido o martírio foram transformadas em relíquias. Em 1575 chegaram ao Brasil duas cabeças das Onze Mil Virgens com grande festa, por serem as primeiras relíquias trazidas para a colônia. Cf. TINHORÃO, Op. cit., p. 34-5. A celebração do Corpo e Sangue de Cristo, instituída pelo papa Urbano IV no século XIII, também ganhou prestígio em muitas cidades portuguesas e brasileiras, com as procissões das ruas enfeitadas com tapetes formados por flores e grãos, carros alegóricos de figuras cristãs e pagãs, além das danças portuguesas das corporações de ofícios. Elementos míticos do sacro e do profano também aparecem no teatro catequético de Anchieta, como o auto Jesus na festa de São Lourenço, misturando a cena do martírio do santo católico a personagens diabólicas representadas por figuras indígenas que, abandonando seus costumes antigos, ao final acolhem os conselhos do Anjo de Deus, fazem o enterro do santo e os meninos índios dançam. Cf. ANCHIETA, José de. Auto representado na festa de São Lourenço. Rio de Janeiro: Serviço Nacional de Teatro - MEC, 1973. Ver também: SANTOS, Danilo José dos. A procissão de Corpus Christi na Vila de Santo Antônio do Recife no
} 
Cardim, em sua visita de 1584 à capitania do Espírito Santo, participou da festa de Nossa Senhora da Conceição, em evento que reuniu na vila toda a população em torno das missas cantadas, indulgências, batismos e casamentos, e assim descreveu as representações dramáticas e os cortejos do evento festivo:

Por haver jubileu concorreu toda a terra, e toda a manhã confessamos homens e mulheres portugueses. Houve muitas comunhões, e tudo se fez com consolação dos moradores índios e nossa. Acabada a missa houve procissão solene pela aldeia, com danças dos índios a seu modo e à portuguesa; e alguns mancebos honrados também festejaram o dia dançando na procissão, e representaram um breve diálogo e devoto sobre cada palavra da Ave Maria [... $]^{44}$.

Ao longo do século XVIII, eram comuns nos principais centros urbanos brasileiros as "entradas" e os ajuntamentos solenes celebrando eventos da vida dos governantes, como casamentos, nascimentos e funerais. Também era motivo de festa a visita de autoridades como a dos bispos do Santo Ofício, nobres e administradores da Coroa Portuguesa, numa afirmação do poder da Metrópole junto à população local e do alcance ultramarino da sua burocracia. Havia ainda o costume de se associar os interesses da Coroa com os da Igreja, através de um extenso calendário cívicoreligioso a ser preenchido pelas festas, que estabeleciam "laços de intimidade com o povo" e atenuavam algumas das tensões decorrentes de um cotidiano marcado em muitos casos pela ausência de liberdades ${ }^{45}$. Nestas datas, em seguida às missas cantadas e os Te Deum realizados no interior das igrejas, ocorriam vários tipos de exibições festivas ao ar livre, como a queima de fogos, bandos de máscaras, passeatas de Reis do Congo, desfiles com música das corporações e os autos e comédias encenadas, entre outras. Uma das mais concorridas manifestações eram os préstitos que contavam com o esplendor de enormes carros alegóricos puxados por animais, como aqueles organizados pelo Capitão General de Mar e Terra Luiz Vasconcellos e Souza para comemorar no Rio de Janeiro as bodas dos infantes de Portugal D. João e

século XVIII como espaço de devoção, status e manutenção do prestígio régio na América portuguesa. Anais do II Encontro Internacional de História Colonial. UFRN, Caicó (RN), v.9 n. 24, set/out 2008. Disponível em: <http://www.cerescaico.ufrn.br/mneme/anais/st_trab_pdf/pdf_4/danilo_st4.pdf> acesso: 10/01/2015.

${ }^{44}$ CARDIM, Op. cit., p. 204-5.

${ }^{45}$ PRIORE, Mary Del. Festas e utopias do Brasil colonial. São Paulo: Brasiliense, 1994, p. 15. 
Carlota Joaquina, no ano de 1786 (figura 8) ${ }^{46}$. Os anais do Senado da Câmara de Cuiabá registram, em outro exemplo de 4 de outubro de 1772, a chegada àquela vila do governante da capitania de Mato Grosso, o general Luiz de Albuquerque de Mello Pereira e Cáceres, tendo sido conduzido em desfile "debaixo de pálio" e acompanhado dos representantes da câmara, nobreza e povo até a igreja da Matriz. Nos dias seguintes houve vários festejos em honra ao dirigente, com óperas e comédias ao ar livre, além de "danças, bailes e outros divertimentos". ${ }^{47}$

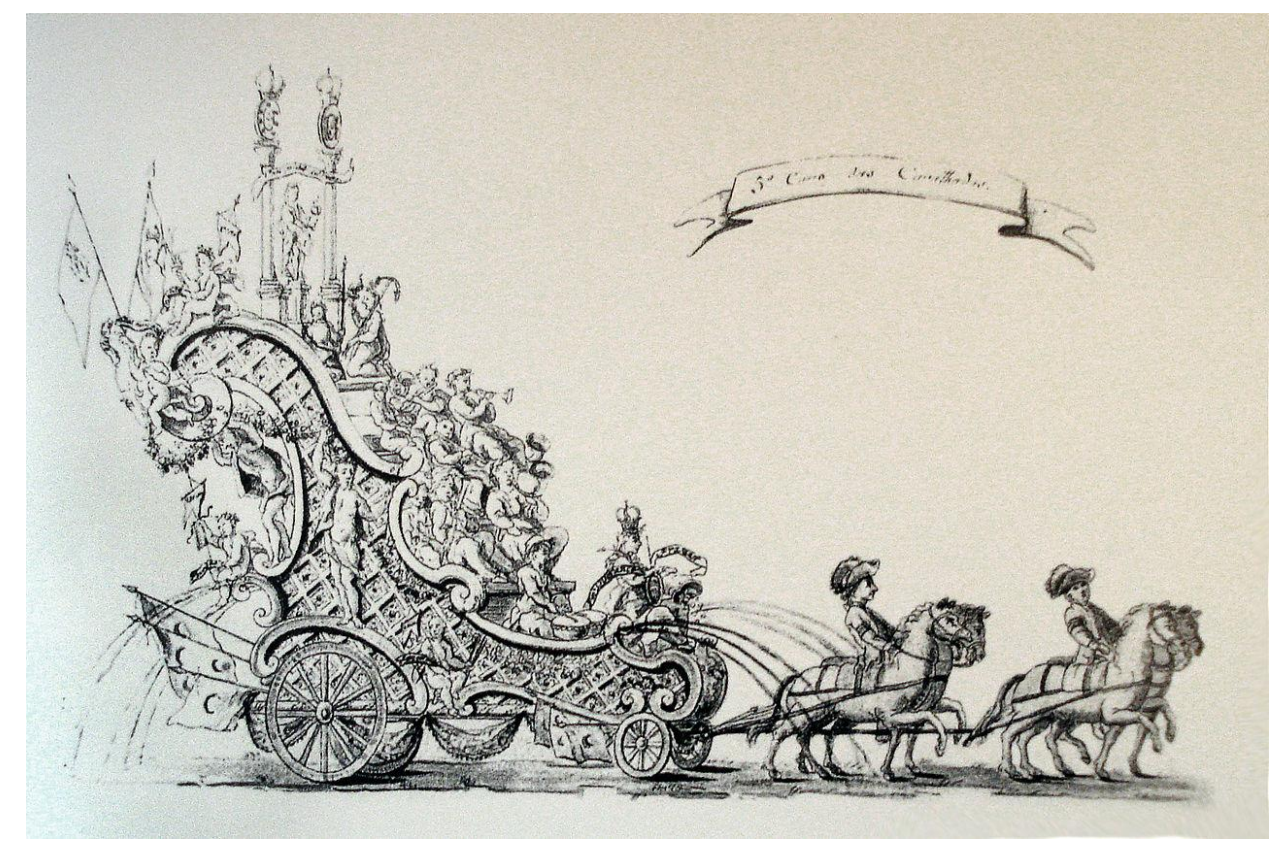

Figura 8: Magníficos carros para a celebração de bodas dos infantes de Portugal Fonte: Reis Pequeno, 1974

Nestes mesmos eventos, Tinhorão identifica elementos de inspirações diversas: o espírito medieval das cavalhadas nas corridas de touros e nos jogos de argolas, a religiosidade de diferentes continentes nas procissões de Corpus Christi e dos Reis do Congo, além do desfile sobre rodas de alegorias barrocas que, segundo o historiador, "valiam por uma encenação espetacular de poder" 48. À medida que se aproxima o final do período colonial, o caráter elitista e o perfil espetaculoso destas manifestações cívicas acabam por perder sua força, permanecendo viva por mais

\footnotetext{
${ }^{46}$ TINHORÃO, Op. cit., p 104.

${ }^{47}$ SIQUEIRA, Joaquim da Costa. Relação Cronológica dos estabelecimentos, fatos e sucessos mais notáveis que aconteceram nestas minas de Cuiabá, registrados nos Livros do Registro das Provisões do Senado da Câmara [1786]. In Crônicas do Cuiabá. Cuiabá: SEC-MT, 2012, P. 99-100.

${ }^{48}$ TINHORÃO, Op. cit. p. 105.
} 
algum tempo a teatralidade barroca dos anos Setecentos apenas nas comemorações religiosas. Isto porque as camadas de baixo, que se divertiam à margem dos eventos, passam a buscar cada vez mais espaço nos desfiles que reuniam corporações de ofícios e confrarias religiosas abrigando negros e mestiços 49 .

Para conquistar fiéis no Novo Mundo, a Igreja Católica apropriou-se de manifestações da cultura mundana, juntando em seus cultos cantigas e danças do português, do espanhol e do gentio. Os vilancetes e seguidilhas, as folias, carolas, e matachins dançados e cantados nos templos e adros da Europa medieval foram aproveitados pelos jesuítas em seus autos de piedade e agradaram em especial aos nativos, que também tinham o momento para as suas danças ${ }^{50}$. Dos aldeamentos indígenas estes dramas se espalharam pelos ciclos de festas dos povoados, tornando as procissões e as folias dos dias santos partes da vida das irmandades religiosas e das paróquias. A estes se juntaram os Congos, as encenações das cortes africanas que eram igualmente marcadas pela pompa. Aos poucos, porém, estas práticas passaram a figurar à margem do culto oficial, conforme apontavam em 1702 as Constituições do Arcebispado da Bahia, recomendando que não se praticassem no interior dos templos "farsas e jogos profanos", "bailes e novenas", tampouco que se fizessem uso de "bebidas e comidas", com a ressalva de poderem as "danças e folias honestas" entrar nas igrejas se as mesmas ocorressem durante as festas.

Pelos inconvenientes que resultam de que as igrejas feitas para louvores de Deus e exercício do espírito servirão de nelas se comer e beber e fazer outras ações muito indecentes ao tal lugar de que nascem mil descomposturas indignas dele: conformando-nos com a disposição de direito, e Sagrado Concílio Tridentino, e Constituição do Santo Papa Pio V, ordenamos e mandamos, sob pena de excomunhão maior e de dez cruzados que nenhumas pessoas eclesiásticas ou seculares tanjam ou bailem, nem façam danças ou jogos profanos, nem se cantem cantigas desonestas ou coisas semelhantes. Porém não é nossa tenção proibir que no adro se possam fazer representações ao Divino, sendo aprovadas primeiro por nós ou por nosso provisor, nem que, outrossim, na ocasião de

\footnotetext{
${ }^{49}$ Ibidem, p. 117.

50 BUDAZ, Rogério. O cancioneiro ibérico em José de Anchiea: um enfoque musicológico. Dissetação de mestrado. São Paulo: Usp, 1996, p. 68-70. Ver também: BOURCIER, Paul. História da dança no Ocidente. São Paulo: Martins Fontes, 2006, p. 48.
} 
festas entrem danças e folias nas igrejas, sendo honestas e decentes enquanto não se disser missa nem se celebrarem os ofícios divinos ${ }^{51}$.

\section{NO BRASIL OITOCENTISTA}

Embora o caráter oficial de algumas das celebrações públicas tenha se transformado ao longo do século XIX em função de um arrefecimento das demonstrações de poder político aqui descritas, apenas no Segundo Império ocorrerão mudanças sensíveis no âmbito das grandes festas das cidades mais povoadas do Brasil. Quando as homenagens aos santos e demais datas festivas do calendário católico cedem parte do seu prestígio para diversões públicas ao gosto da burguesia, como no caso, segundo Tinhorão, dos bailes dos salões, o teatro musicado e os primeiros corsos carnavalescos da capital do Império ${ }^{52}$. Mesmo assim, a tradição dos cortejos, da música e da dança como instrumentos de devoção permanecerá no centro da vida social de grande parte dos povoados brasileiros e da área rural propriamente dita, incluindo os aldeamentos indígenas voltados à catequese. Esta tradição será também objeto do olhar estrangeiro, despertando a curiosidade e o estranhamento de seus viajantes em relação a práticas religiosos encontradas em diversas partes do território brasileiro, conforme veremos, a seguir, nos relatos dos franceses Castelnau, Saint-Hilaire, Biard e Florence, dos germanos Wied-Neuwied, Spix, Martius, Steinen e Schmidt, e do português Moutinho.

Em janeiro de 1817, o príncipe Maximiliano de Wied-Neuwied visita Ilhéus e lá observa a festa de São Sebastião. Admira-se com o fato de ser a cidade tomada durante vários dias pela celebração, que, além dos cultos na igreja, oferece aos participantes músicas e encenações diversas, como as máscaras e as cheganças representando o combate entre mouros e cristãos. Em sua crônica, o viajante também ressalta o clima de alvoroço na cidade, condenando a "ociosidade" e "toda espécie de desordens" provocadas por tamanha mobilização em torno do que ele chama de

\footnotetext{
${ }^{51}$ Constituições Primeiras do Arcebispado da Bahia, feitas e ordenadas pelo llustríssimo e reverendíssimo Senhor Don Sebastião Monteiro da Vida, arcebispo do dito arcebispado e do Conselho de Sua Magestade: propostas e aceitas em o sínodo diocesano que o dito celebrou em 12 de junho do ano de 1707. [Coimbra, Real Colégio das Artes da Companhia de Jesus, 1720] São Paulo: Typografia Antônio Louzada Antunes, 1953, p. 268-9.

52 TINHORÃO, Op. cit., p. 133.
} 
“cerimônias externas". Esta é também a parte da festa pela qual os índios da região se veem atraídos.

Cheguei a Ilhéus no fim de semana do Natal [e] já estavam nos preparativos para celebrar a de São Sebastião. Erguera-se um alto mastro enfeitado de bandeiras e, no dia da festa, homens mascarados percorriam a cidade, ao som de tambores e fazendo toda sorte de brincadeiras. Durante o dia [ouviam-se] muitos tiros de espingarda nas ruas ao passo que, durante a noite, o som do violão e das mãos, batendo em acompanhamento dos batuques, ressoava por toda a parte. Os mais ricos habitantes custeiam esses festejos; costuma-se representar a vida do santo por mascaradas, cenas de teatro, combates e outros espetáculos do gênero. As pessoas que representam nessas pantomimas absurdas são escolhidas alguns dias antes, e vestidas apropriadamente. No dia de São Sebastião, havia dois partidos que guerreavam [entre si], os portugueses e os mouros; cada qual tinha seus capitães, seus tenentes, suas insígnias. Erguerase junto da igreja uma fortaleza de ramadas. Os mouros tomam a imagem do Santo e levam-no para a sua fortaleza; na última noite o partido oposto toma-a de novo e a conduz para a igreja, com grandes demonstrações de respeito. Essa representação durou vários dias, durante os quais o povo vivia num constante movimento e não saía da igreja; só se ocupava, ao mesmo tempo, de se divertir entregandose à ociosidade e a todas as espécies de desordens. Os índios, que não demonstram a menor disposição para os dogmas e preceitos da religião, tomam às vezes parte muito ativa nessas pantomimas e nas cerimônias externas. Por isso, veem-se os missionários aproveitar muitos dos costumes dos selvagens para conseguir a aceitação de sua doutrina por essas gentes ${ }^{53}$.

Em outro exemplo, o naturalista e pintor francês Auguste François Biard, que esteve no Brasil em 1858 e 1859, testemunhou o culto a São Benedito pelos índios Tupiniquim da aldeia Destacamento, na província do Espírito Santo. Revelando detalhes que se assemelham às práticas notadas em Mato Grosso no mesmo período, Biard ressaltou em sua narrativa pontuada de sátira e ironia a importância da música para os festejos, descrevendo o incessante som de tambores e ganzás por toda a aldeia, além da dança a cargo das mulheres da tribo. Também destacou o consumo de álcool entre os moradores, tanto o da aguardente de cana do colono quanto o de suas

${ }^{53}$ WIED-NEUWIED, Op. cit., p. 345. 
próprias beberagens, lembrando em alguns detalhes os relatos feitos por Koslowsky e Schmidt acerca do cururu dos índios Guató no alto Paraguai.

Eles faziam preparativos para essa festa uns seis meses antes e guardavam dela uma recordação pelos outros seis meses do ano. Desde o momento em que esse tambor começa a ser tocado, não para mais, nem de noite nem de dia. [...] Em todos os tetos em que entrávamos bebia-se "câouêba" e cachaça, e a pretexto de se cantar, berrava-se. Mantinham-se os homens sentados tendo entre as pernas um tambor primitivo fabricado com pequeno tronco de árvore oco coberto por um pedaço de couro de boi; outros homens esfregavam uns pauzinhos, num instrumento feito de bambu todo entalhado. Ao som desse charivari, mulheres, mesmo velhas, dançavam devotamente um desgracioso cancã que mereceria certamente a reprovação de nossos virtuosos agentes de polícia. Depois de se ter dançado bem e melhor bebido e urrado, numa casa, ia-se fazer o mesmo numa outra habitação. Numa dela tive a coragem de beber numa espécie de cabaço a tal "câouêba", o que fiz, aliás, para despertar simpatias e conseguir depois me permitissem uns retratos. Não ignorava como se prepara essa bebida: sabia que as mulheres idosas (são elas sempre as encarregadas das funções mais importantes) mastigam raízes de mandiocas antes de deitá-las numa vasilha; cada uma de sua vez cuspia nessa panela o conteúdo das suas bocas e deixavam a massa fermentar. Como se vê, em mim, o amor à arte sobrelevara o instinto da repugnância ${ }^{54}$.

Biard, em outro momento daqueles dias de festa em Destacamento, recebera ainda uma horaria especial, antes da procissão que conduziria a imagem de São Benedito à capela da aldeia. Um dos índios improvisou com o acompanhamento de "um violão" alguns versos cantados em homenagem ao visitante francês, que assim reproduziu o estribilho:

Su Bia ao sertão guerea

Matar passarinhos

Su Bia ao sertão

E também souroucoucou ${ }^{55}$

\footnotetext{
${ }^{54}$ BIARD, François Auguste. Dois anos no Brasil. São Paulo: Cia Ed. Nacional, 1945, p. 100.

$55 \mathrm{O}$ viajante fez a seguinte tradução para o francês dos versos: M. Biard dans la montagne / Désire tuer petitis oiseaux, / M. Biard dans la montagne / Cherche aussi serpentes dangereux [Sr. Biard na montanha / Quer matar pequenas aves / Sr. Biard na montanha / Buscando serpentes perigosas]. Ibidem, p. 101.
} 


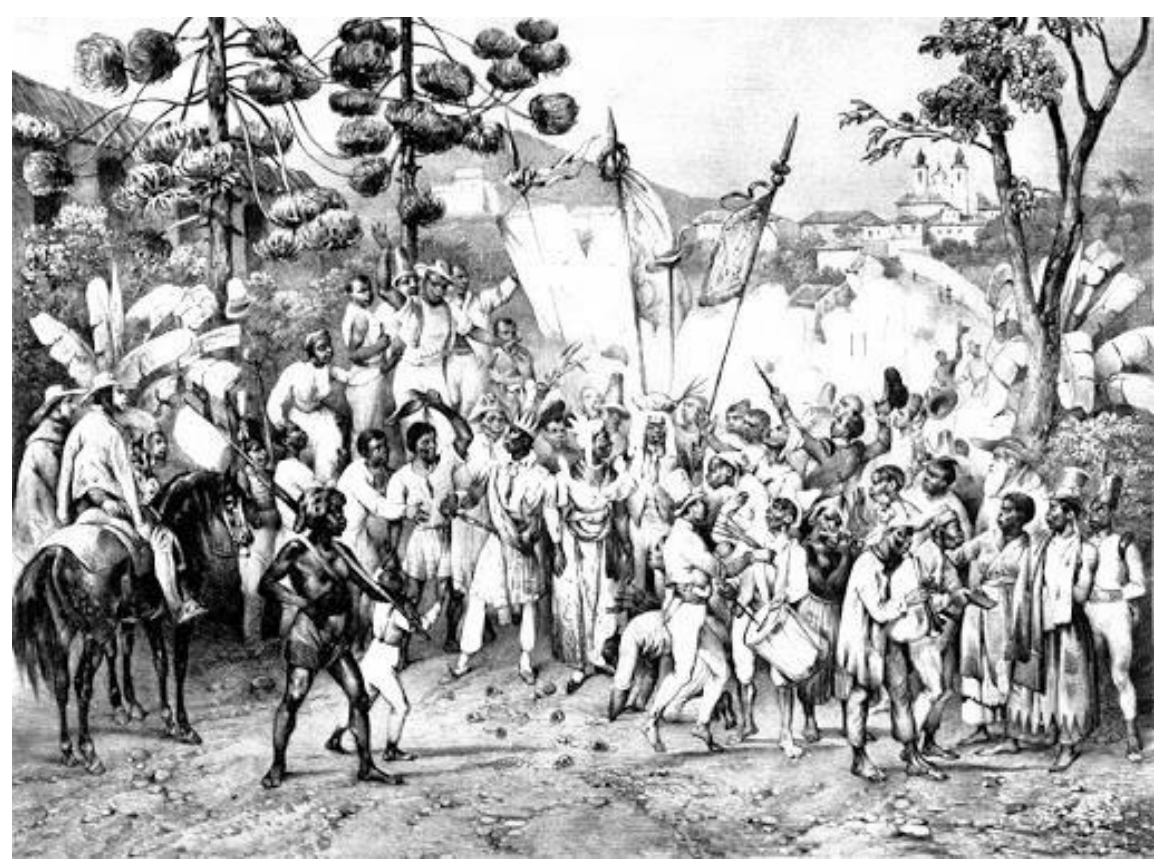

Figura 9: Rugendas, congada na festa de N. S. do Rosário Fonte: Reis Pequeno, 1974

Francis de Castelnau foi outro viajante a expressar sua estranheza diante da entrega dos brasileiros aos costumes das festas. Adotando um tom muitas vezes cáustico, o francês descreveu a festa de Santo Antônio em Vila Bela da Santíssima Trindade, em Mato Grosso no ano de 1847, destacando a participação da população negra no culto ao santo católico. Outro curioso aspecto naquela cidade de clima pouco amigável a um europeu, por ele chamada "inóspita" e "pestilenta", foi a paisagem sonora que Castelnau identificou como pertencente a todas as festas de santos brasileiras.

[...] fomos logo cedinho despertados pelo tremendo barulho de sinos, tambores, cornetas, bombas, etc., acompanhamento infalível de todas as festas brasileiras. Pouco depois vieram buscar-nos para almoçar em palácio e daí seguir para a capela de Santo Antônio, que é pequena, mas, pelo menos, despida da infinidade de ornamentos de péssimo gosto, que atravancam geralmente as igrejas da terra. Quatro eram os padres, dois brancos, um preto e um mulato. A capela estava cheia de mulheres, pretas na sua grande maioria; de tudo porém o que me pareceu mais extraordinário era a música, mais parecida com a que fazem os gatos nas suas expansões amorosas. A procissão saiu da igreja ao meio-dia. [...] Nas paradas, uma menina, vestida de alvo, subia numa cadeirinha trazida por um negro, e recitava versos em honra ao santo, por entre o barulho dos tambores 
e das trombetas [...], enquanto a multidão de pretos entoava em volta os cânticos próprios do dia56.

Duas décadas antes, o também francês Hercules Florence integrava como desenhista e cartógrafo a expedição do barão de Langsdorff, que percorreu o interior do Brasil de 1825 a 1829. Registrou em aquarela a Festa do Divino, em janeiro de 1828 (figura 1), e os festejos em homenagem a São Benedito, em abril do mesmo ano, na Vila de Nossa Senhora da Conceição do Alto Paraguai Diamantino. Nesta última festa, organizada por uma família abastada de negros, presenciou a congada de Diamantino, em exibições de um luxo, segundo o próprio Florence, "tão ostentoso quanto estúpido".

Conheci um velho preto de nação cabinda que, depois de conseguir a dinheiro sua libertação, a de sua mulher e filhos, comprara por seu turno lavras e escravos. Esse estimável negro tinha já por vezes dado a liberdade a uns vinte cativos seus e possuía ainda trinta, todos sãos, fortes e contentes. No dia de São Benedito, santo de cor preta e padroeiro de sua raça, deu ele uma festa, para a qual convidou os principais habitantes, sem se esquecer de nós. Depois de assistirmos à solenidade religiosa na igreja, fomos levados com os mais a uma mesa de doces muito bem servida. Em seguida executaram os escravos um bailado da terra deles, percorrendo no resto do dia a vila e dançado nas ruas e casas ${ }^{57}$.

Igualmente digna de nota era a preocupação com demonstrações exteriores de religiosidade por parte de alguns habitantes abastados do vale do São Francisco, na passagem dos alemães Johann Baptist von Spix e Carl von Martius pelo sertão mineiro, em 1818. Os naturalistas comparam ironicamente o costume revelado no sertão mineiro com as ostentações de fé vistas em Portugal.

Uma fazendeira rica dos arredores tinha feito a Nossa Senhora a promessa de uma procissão, para a qual a gente da freguesia e também nós fomos convidados. A dama vestida de gala conduzia o séquito até à igreja, para assistirmos à missa, e de lá voltamos todos a casa dela, onde estava posta uma grande mesa com as mais finas iguarias e vinhos escolhidos, e, sobretudo, deliciosos doces, da qual

\footnotetext{
${ }^{56}$ CASTELNAU, Op. cit., p. 364-5.

${ }^{57}$ FLORENCE, Op. cit., p. 201.
} 
os amigos da bela penitente eram convidados a participar o dia inteiro. 0 mais singular é que, com esse ato de contrição, a promotora da festa expiatória toma o soberbo título de rainha, nomeia os seus amigos mais íntimos e a gente do séquito, formando aparatosa corte, e, como recordação da festa de sua humildade, distribui medalhinhas de ouro e prata. Essa Festa da Rainha, festa ex-voto, dá motivo para grandes despesas; [...] para um simples copo d'água passa-se até necessidade o ano inteiro, para gastar na ostentação da fé religiosa, tudo num só dia ${ }^{58}$.

Outro francês, o naturalista e botânico Auguste de Saint-Hilaire, escreveu sobre os costumes e a natureza do povoado de Santa Luzia, na região mineradora de Goiás, por ocasião das comemorações da festa do Divino Espírito Santo, em 1819. Era a ocasião em que os camponeses saíam de suas terras e compareciam ao povoado em suas obrigações para com a igreja. Saint-Hilaire fala da dificuldade dos moradores em possuir roupas para os dias de festa e da necessidade guardar o domingo e os dias santos para o lazer. Apesar de viverem da produção de suas fazendas, a vida material destes homens se ressentia do declínio da exploração do ouro e das grandes distâncias dos demais povoados a que estavam subordinados.

Esta gente não vinha aí a não ser uma vez por ano, e para confessarse e assistir à Páscoa aproveitavam a oportunidade das festas de Pentecostes, que se celebram, no Brasil, com grande júbilo e muita solenidade. [...] Não há um único homem que não queira possuir uma roupa própria para os dias de festa, nenhuma mulher que não deseje possuir um vestido de chita, um colar, brincos, lenço de musselina, uma capa de lã, um chapéu de feltro, e a venda desses objetos, que custam aqui preços exorbitantes, basta para retirar da região o escasso ouro e numerário que ainda aí circula. Já não há em Santa Luzia senão pequeníssimo número de lojas muito mal sortidas; tudo se compra a crédito. [...] Certos colonos caíram em tal miséria, que ficam meses inteiros sem poder salgar os alimentos, e quando o pároco faz a sua excursão para a confissão pascal, sucede frequentemente que todas as mulheres da mesma família se apresentam uma após a outra com o mesmo vestido ${ }^{59}$.

\footnotetext{
${ }^{58}$ SPIX e MARTIUS, Op. cit. v. 2 p. 100-1.

${ }^{59}$ SAINT-HILAIRE. Op. cit., p. 25-30.
} 
O português Joaquim Ferreira Moutinho, que viveu em Mato Grosso por quase duas décadas, também noticia a festa do Divino Espírito Santo, no início da década de 1850. Em sua época, a festa do Divino em Cuiabá possuía um perfil elitista comparável ao das comemorações atuais, com o mesmo prestígio social conferido aos festeiros organizadores da festa que tinham os seus nomes sorteados. Além das solenidades programadas ao longo da semana, que contavam com a participação das mais ilustres autoridades, eram doados alimentos aos mais pobres e oferecidos jogos e espetáculos ao ar livre, como touradas e comédias encenadas.

Os festejos em louvor do Espírito Santo são os mais populares e pomposos. 0 festeiro é eleito por sorte. Antes do dia da festa sai ele acompanhado de música e de algumas pessoas, com as insígnias que se compõem de uma coroa de prata, cetro e bandeira, a pedir esmolas que montam ordinariamente a dois contos de réis, e até mais. No dia do Espírito Santo o imperador vai à igreja dentro de um quadrado formado por quatro varas de madeira, cujas extremidades são seguras por quatro homens escolhidos sempre entre pessoas de mais distinção, levando numa salva a coroa e o cetro, precedido da bandeira. Assiste à missa que é pontifical e à tarde acompanha pela mesma forma à procissão. Na véspera há iluminação e fogos de artifício desde a porta da matriz até a casa do festeiro, onde está armado um riquíssimo altar. Depois de concluídos os atos religiosos, há distribuição de carne verde e víveres aos pobres, assim como de pequenos pães a todo o povo. As autoridades recebem presentes especiais que se compõem de grandes roscas de trigo enfeitadas de flores e laços de fitas. Por fim seguem-se as corridas de touros, comédias, bailes, etc., cujas despesas correm por conta do imperador, e montam muitas vezes a 4 e 5 contos de réis ${ }^{60}$.

Moutinho também nos fala do seu interesse por outra celebração religiosa em Cuiabá, a dos feriados da Semana Santa. Nesta data, o cronista português ressalta a atmosfera contida e solene dos eventos, traduzida na vestimenta dos devotos e nas marchas fúnebres a cargo das bandas das corporações militares; nos sons dos tambores, dos sinos e das matracas, bem como do canto solitário representando Maria de Magdalena.

\footnotetext{
${ }^{60}$ MOUTINHO, Joaquim Ferreira. Notícia sobre a província de Mato Grosso. São Paulo: Typografia de Henrique Schroeder, 1869 p. 21.
} 
O dia de sexta-feira da Paixão é completamente silencioso, e o caráter tristonho e majestoso de que se reveste, convida ainda os mais descrentes à meditação e ao recolhimento. A procissão do Enterro, que tem lugar ao terminar o ofício das trevas às 8 horas da noite é feita com luxo, acompanhada de quase toda a população que comparece a esse ato vestida de luto. Segue-a também a força militar com armas em funeral, e a [banda de] música que toca então somente peças fúnebres, sendo o próprio tambor coberto de pano preto, produzindo por isso um som lúgubre e surdo. Quando cessa a voz instrumental, o silêncio é apenas interrompido pelo canto suave e terno de Maria Magdalena ao desenrolar o Sudário ensanguentado do Senhor. Os sinos ficam mudos, e são substituídos pela matraca desde quinta-feira santa até o meio dia do sábado de Aleluia61.

A preocupação dos festeiros com o cumprimento de todos os compromissos que envolviam a organização das comemorações religiosas em Cuiabá, a despeito dos enormes custos em dinheiro e da constante carência artigos necessários à subsistência mínima das pessoas, muito admirava Moutinho, uma vez que eram poucos os que realmente se comportavam como pessoas de fé.

Na festa da Semana Santa, para a qual a mesa do S. S. Sacramento elege um provedor, dispende este não pequenas quantias, começando as despesas desde o primeiro domingo da quaresma. Em um país aonde tudo é excessivamente caro, e os meios de vida dificílimos pela falta de muitos objetos indispensáveis à vida, estas festas são um tributo por demais pesado ao povo. Entretanto, logo que qualquer indivíduo é eleito festeiro (apesar de não serem os cuiabanos muito amantes da carolice), não poupa despesas e esforçase sempre por fazer sua festa com a solenidade e pompa condignas de tão grandes e elevados assuntos ${ }^{62}$.

Três décadas mais tarde, Karl von den Steinen também nos fala das manifestações de devoção católica em Cuiabá. Ao tratar das festas do calendário religioso oficial, em março e abril de 1884, o cronista faz uma mistura de impressões e fatos relacionados às comemorações do Domingo de Ramos, da Semana Santa e Pentecostes. Nos eventos que antecedem a Semana Santa, o viajante destaca a

\footnotetext{
${ }^{61}$ Ibidem, p. 21-2.

62 Idem.
} 
procissão de Ramos, com o acompanhamento de três bandas de música e a participação de autoridades, como o bispo, o presidente da província, o chefe de polícia, oficiais e um padre que lia "um belo sermão na rua" 63 .

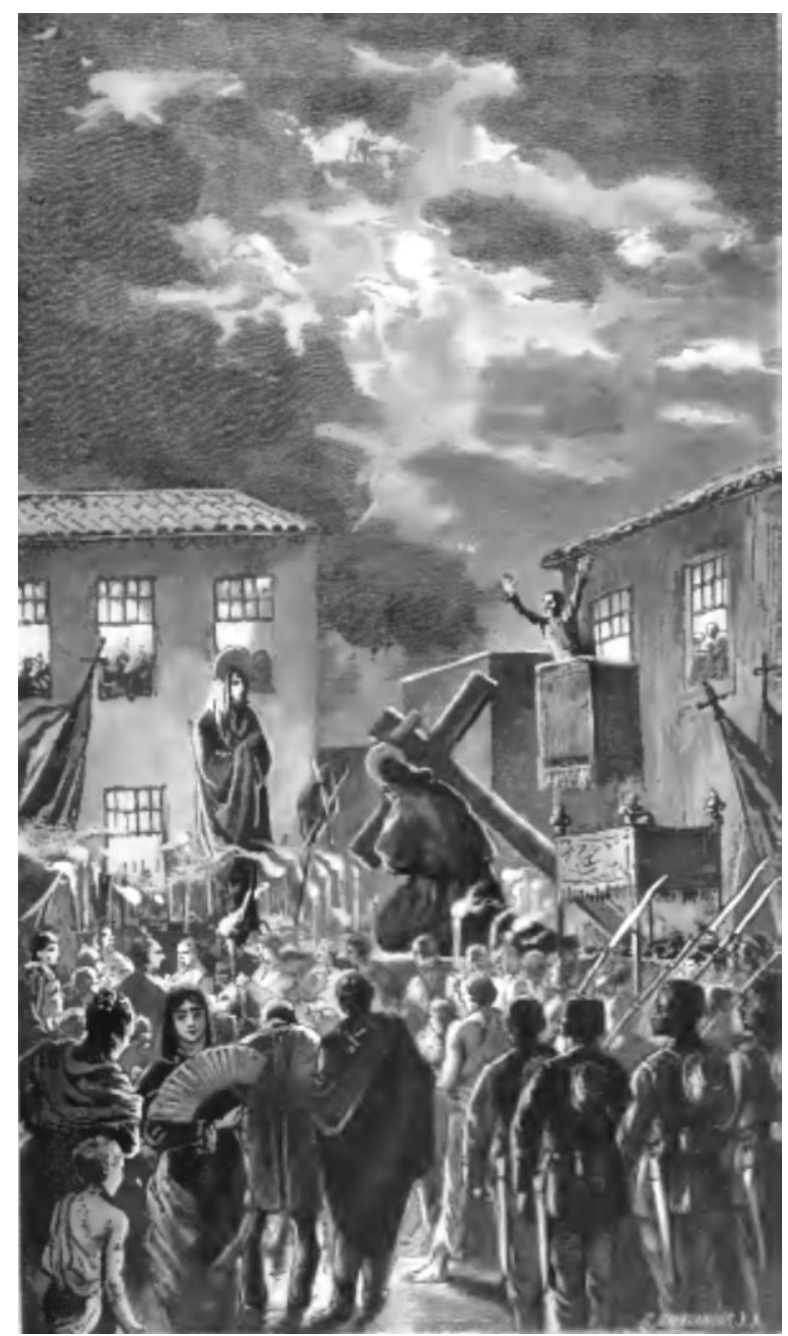

Figura 10: Johannes Gehrts, Semana Santa em Cuiabá Fonte: Steinen, 1886

Durante as datas da Paixão e Ressurreição de Cristo, os detalhes que mais impressionaram o alemão foram a pompa e o luto imprimidos pelos moradores da cidade, em cortejo da igreja do seminário à capela do Rosário, onde desfilavam duas ordens de militares portando baionetas e archotes, uma vestida de vermelho e outra de roxo, que o levou a perguntar: "estaríamos no teatro?" ${ }^{64}$. Ainda segundo Steinen, a

\footnotetext{
${ }^{63}$ STEINEN, O Brasil central, Op. cit., p. 89.

${ }^{64}$ Ibidem, p. 90.
} 
imagem do Cristo representando o Calvário sobre o andor era um dos elementos mais dramáticos na caracterização da Paixão (figura 10):

Carregado numa eça e dobrado sob o peso da cruz apareceu a figura de Cristo, de quase duplo tamanho natural, a roupagem purpúrea e uma corda de ouro atirada ao pescoço. Atrás de Cristo, vinha um baldaquim contendo o santíssimo, depois o bispo e os padres e os dignatários. As velas vinham, agora, na frente, e, lentamente, a procissão se movimentava colina abaixo, completada pela banda de música e uma companhia de soldados de baioneta calada. [...] 0 fulgor amortecido das velas dentro do crepúsculo, a imagem enorme ajoelhada, dominando pesadamente sobre as cabeças, o efeito daquelas cores maravilhosas misturadas com as roupas negras, suavizadas pela amenidade da tarde que findava, a coluna militar de baionetas reluzentes, tudo isso era de efeito impressionante ${ }^{65}$.

\section{AS FESTAS DA ARRAIA-MIÚDA}

É possível identificar nas descrições de Steinen uma parcela do caráter cívicoreligioso apontado por Tinhorão nas festas coletivas do século XVIII, onde cabia à elite ligada ao poder da Metrópole todo o protagonismo das celebrações organizadas nas principais cidades brasileiras. Na prática, o espaço reservado nestas festas para o "povo miúdo" era o do espectador, ficando os seus ritos com cantos, danças e dramas de devoção confinados nos arredores destes centros e nos rincões. Cenas como estas, caracterizadas pelo espetáculo e o elitismo, já não são vistas por Max Schmidt em sua visita ao povoado mato-grossense de Rosário do Rio Acima, na festa da Imaculada Conceição, no último dia do ano de 1900. Ali, Schmidt presenciou o culto à santa em uma das casas de famílias, com o cururu cantado e dançado em frente ao altar. Na mesma residência, chamada pelo cronista de "mísera cabana", conheceu também o siriri dançado do lado de fora, numa roda animada durante toda a madrugada ${ }^{66}$.

Com os festejos prosseguindo na manhã seguinte, Schmidt também assistiu pela tarde ao cortejo do reisado do Congo, com suas roupas e insígnias colorindo e imprimindo brilho à paisagem do modesto lugarejo ${ }^{67}$. Assim como na devoção dos

\footnotetext{
${ }^{65}$ Idem.

${ }^{66}$ SCHMIDT, Op. cit., p. 13-14.

67 Ibidem, p. 16.
} 
negros à Virgem do Rosário e a São Benedito, o catolicismo dominante se mesclou pelas mãos dos negros a representações originárias do continente africano, tendo os congados sido aceitos pelas autoridades da igreja como um meio de se manter no rebanho aquelas almas. No entanto, esta mesma simpatia pelos bailados dramáticos do Congo não ocorria com os rituais africanos praticados à noite em terreiros e estradas na zona rural que, segundo Tinhorão, eram muitas vezes confundidos com atividades apenas lúdicas e chamados genericamente de batuques ${ }^{68}$. Cultos clandestinos que, mesmo passando funcionar nas residências de escravos libertos e seus descendentes, sofreriam a censura das autoridades, conforme atesta o parágrafo oitavo das Posturas Policiais editadas pela Câmara Municipal de Cuiabá, em 04 de janeiro de 1831:

Sendo conveniente dissipar-se o péssimo abuso de misturar-se o profano com o Divino, como continuadamente se vê não só nesta cidade [ilegível] festejando-se este ou aquele santo com terço e ladainha $[\mathrm{e}]$ rematando-se esta festividade com a indecente e obscena dança de batuque e outras semelhantes; portanto, de ora em diante, ficam proibidas tais funções de mistura, com a pena do dono da casa ou inquilino que tal consentir pagar à Câmara $8 \$ 000$ de multa, ou oito dias de cadeia69.

É possível que, juntamente com proibição à "indecente e obscena" dança dos negros, houvesse a determinação de se banir das festas católicas alguns excessos também vistos nas folgas de origem portuguesa. Seriam estas as "outras semelhantes" citadas nas Posturas Policiais de 1831? A musicóloga Yara Moreira destaca no período colonial a presença na paraliturgia católica de danças incorporadas ao teatro e às procissões pelos padres jesuítas, que com o tempo deixaram de ocupar os altares das igrejas, a exemplo das Folias dos Santos Reis ${ }^{70}$. Carlos Brandão é outro pesquisador que chama a atenção para os casos "fervorosamente festivos e barulhentos" das folgas dos devotos de várias partes do interior do Brasil que, via de regra, fugiam ao controle dos párocos, levando-os a combater antigas tradições locais.

\footnotetext{
${ }^{68}$ TINHORÃO, Op. cit., p. 89.

${ }^{69}$ Posturas Policiais da Câmara Municipal da Cidade de Cuiabá, de 04 de janeiro de 1831. Acervo: APMT, PM 02 , Caixa 1.

${ }^{70}$ MOREIRA, Yara. De Folias, de Reis e de Folias de Reis. Revista goiana de artes. UFG vol. 3 n. 2 jul/dez 1982, p. 126.
} 
Para Brandão, é principalmente a partir do processo de romanização da igreja católica no Brasil, iniciado em fins do século XIX, que estes folgazões serão "aos poucos expulsos do interior dos templos e das procissões para o adro, a praça a periferia pobre das cidades e, daí, para as estradas e terreiros do mundo rural". ${ }^{71}$

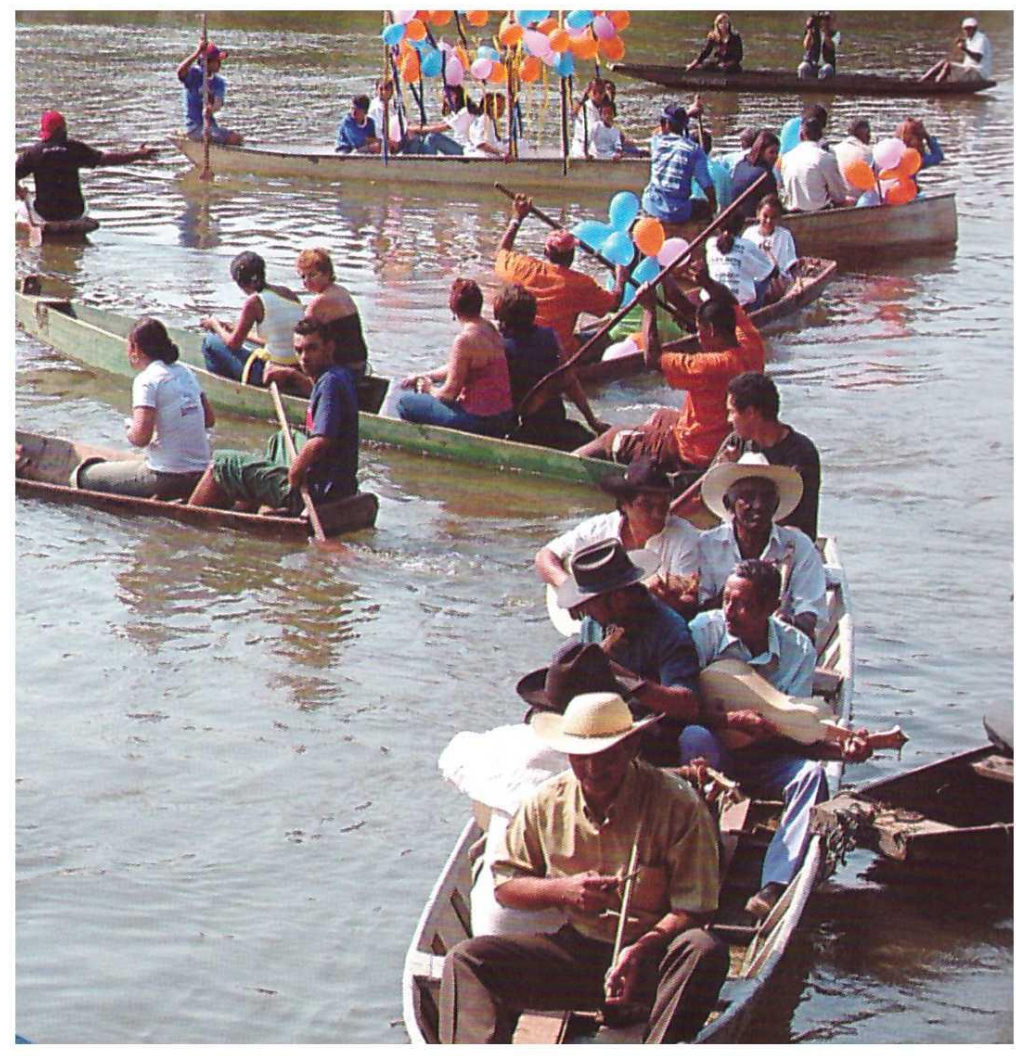

Figura 11: Saída da procissão fluvial pelo rio Cuiabá, na comunidade beira-rio de Bonsucesso Fonte: Loureiro, 2006

Com o cururu não haveria de ser diferente. Tendo a sua prática sido noticiada desde a primeira metade do século XIX na área rural, nos arredores de algumas das cidades antigas de Mato Grosso e em aldeias indígenas como a dos Guató e dos Guaná, os seus agentes por certo não poderiam contar com a presença constante de padres dirigindo os seus ritos. Os cultos teriam, deste modo, que ser organizados pela sua própria gente, sendo esta forma de isolamento a maior razão para que "a criatividade do povo se exprimisse mais livremente", criando assim oportunidades para que se engendrassem "instrumentos, rituais, danças e outras manifestações singulares". ${ }^{72} 0$

\footnotetext{
${ }^{71}$ BRANDÃO, Carlos Rodrigues. Prece, folia, festa e romaria. Aparecida, SP: Ideias e Letras, 2010, p 42.

72 LOUREIRO, Op. cit., p. 23.
} 
percurso histórico traçado até aqui nos permite assegurar que a religião representada através dos cantadores do cururu se fez através dos pobres, no universo cultural ribeirinho, com a sua fé revivida todos os anos nas casas dos vilarejos e nas áreas rurais; nas procissões dos bairros, nos caminhos tropeiros e nos rios (figura 11). Esta é, provavelmente, a razão pela qual não são encontrados nos antigos registros fotográficos das principais cidades de Mato Grosso os cururueiros animando as festas religiosas que desde o seu início se revestiram da pompa de seus organizadores ilustres ${ }^{73}$.

Com isso, não foram poucos os lugares do Brasil católico onde a tradição do culto aos santos se firmou a despeito da presença dos seus clérigos. Enfrentando a escassez de pessoas e recursos, o isolamento dos povoados e tantas outras dificuldades próprias da natureza dos trópicos, os habitantes destes sítios tiveram em diversos momentos que criar suas próprias formas de religiosidade, fazendo delas elementos singulares de suas culturas. Um processo iniciado nas primeiras décadas da Colonização, com os missionários inacianos como os portadores dos ideais da Contrarreforma, acolhendo vários elementos das culturas autóctones em suas práticas catequistas, muitas vezes sob a reprovação de seus superiores. Assim os ritos populares continuaram, ao longo dos séculos, incorporando superstições e cantos, num rico processo em que as práticas trazidas pelos primeiros evangelizadores europeus se mesclaram aos elementos nativos já existentes e às influências externas seguintes. E até nos tempos mais recentes, quando não se podia, por meses, contar com a assistência de um pároco, lá estavam os devotos, nos lugarejos e nos bairros rurais, junto aos capelães, as rezadoras, benzedeiras, cantadores e folgazões de respeito na região; prontos a animar com suas toadas e folias as festas, procissões e rezas; cumprindo promessas, realizando simpatias e curas, e zelando pelas casas das famílias, pelas capelas e suas imagens sagradas.

\footnotetext{
${ }^{73}$ Nas fontes disponíveis acerca das fotos antigas de Mato Grosso, encontramos registros de diversas bandas militares e dos músicos da Lira Operária, dirigida por Mestre Inácio. Nenhuma fotografia dos cururueiros e suas violas-de-cocho. Cf. LUCIDIO, João Antonio Botelho. Ofício e Arte: fotógrafos e fotografia em Mato Grosso (1860-1960). Cuiabá: Carlini e Caniato/EdUFMT, 2008. Ver também: FREITAS, Maria Auxiliadora de. Cuiabá, imagens da cidade: dos primeiros registros à década de 1960. Cuiabá: Entrelinhas, 2011.
} 
Em Mato grosso, algumas das festas religiosas comunitárias que foram documentadas no século XIX tinham o aparato das grandes celebrações cívicoreligiosas inspiradas na tradição colonial portuguesa. Em outras mais pobres, havia a devoção dos evangelizadores do Cururu. 


\section{CAPÍTULO $v$}

NOVOS PALCOS

Sou filho de Mato Grosso

Não nego meu natural

Moro na cidade branca

Capital do Pantanal

Toada de Cururu de Agripino Magalhães

A política atual de valorização das tradições no estado de Mato Grosso segue intrinsecamente ligada à representação do popular. Basta observarmos a frequência com que grupos de dança folclórica são chamados a entreter o público nos eventos de grande repercussão midiática, ocupando lugar de destaque na vitrine do atual programa de desenvolvimento econômico do Estado. O grupo de Siriri Flor Ribeirinha, sediado na comunidade São Gonçalo Beira Rio, à margem esquerda do Rio Cuiabá, é um dos exemplos do sucesso dessas ações, com seu currículo exibindo várias apresentações em todo o país e no estrangeiro. Atualmente atreladas à economia do turismo e ao comércio exterior de produtos do campo, o artesanato e a gastronomia locais são duas outras atividades de forte apelo promocional que, somados à música e à dança, tiveram um largo aproveitamento, por exemplo, nas ações publicitárias em torno do campeonato mundial de futebol de 2014. Atrativos que fizeram parte, aliás, do enredo escolhido para o desfile da escola de samba Estação Primeira da Mangueira, no carnaval de 2013 no Rio de Janeiro, com a prefeitura de Cuiabá e as empresas locais destinando, à época, 2,6 milhões de reais em patrocínios para a agremiação carioca ${ }^{1}$. 0 mesmo deve ser dito a respeito de algumas tendências figurativistas nas artes visuais presentes na paisagem urbana das principais cidades mato-grossenses, representações de tipos e cenas pitorescas nas

\footnotetext{
${ }^{1}$ G1 MATO GROSSO. Cuiabá será tema de enredo da Mangueira no carnaval de 2013 em RJ. Publicado em 07/05/2012. Disponível em:< http://g1.globo.com/mato-grosso/noticia/2012/05/cuiaba-sera-tema-deescola-de-samba-no-rio-de-janeiro-em-2013.html > Acesso em: 23/04/2015.
} 
artes cênicas, além dos seus ritmos populares característicos - o Cururu, o Siriri e o Rasqueado - que compõem hoje um conjunto de símbolos representativos de uma identidade cultural da região.

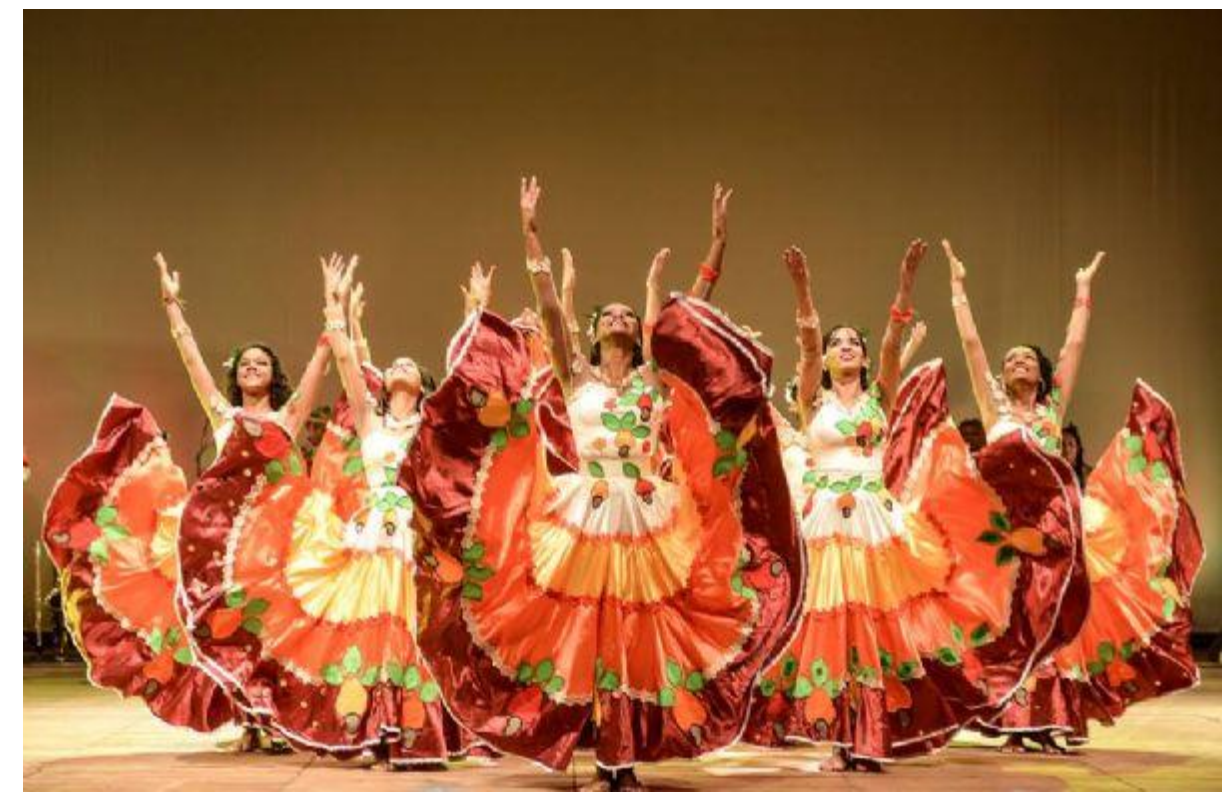

Figura 1: grupo de Siriri Flor Ribeirinha

III Encontro Nacional de Danças Populares, RS

Fonte: Leonor, 2015

Esse interesse pela representação nativa do lugar através das expressões oriundas das classes populares tem como marco a política da Universidade Federal de Mato Grosso (UFMT) para a área, implementada a partir de sua fundação em 1970. Com a proposta de valorização da cultura popular e do indigenismo, o Museu de Arte e Cultura Popular (MACP) foi, desde a sua criação em 1974, o organismo acadêmico responsável pela formulação de um programa voltado para projetos de ações comunitárias, oficinas e mostras livres de arte, além de programas de pesquisa e formação de um acervo temático ${ }^{2}$. Segundo Suzana Guimarães, o programa visava integrar a produção artística local ao circuito brasileiro, orientando o seu conteúdo para o "fazer popular cuiabano", assim como toda a Universidade se comprometia, através do discurso de seu reitor fundador Gabriel Novis Neves, com "a criação e a legitimação de um saber vinculado às questões regionais" 3. Essa orientação coincidiu com uma maior participação do governo federal nas questões ligadas à cultura, em

\footnotetext{
${ }^{2}$ UNIVERSIDADE FEDERAL DE MATO GROSSO. Pró-reitoria de Cultura, Extensão e Vivência. Disponível em: <http://www.ufmt.br/ufmt/unidade/index.php/secao/siteAlt/1168/137/PROCEV> Acesso em: 24/04/2015.

3 GUIMARÃES, Suzana. Arte na rua: o imperativo da natureza. Cuiabá: EdUFMT, 2007, p. 86.
} 
coerência com a proposta de um Plano de Ação Cultural formulado em 1973 pelo Conselho Federal de Cultura, objetivando fortalecer a cultura e o patrimônio histórico e artístico nacional pela perspectiva da regionalização ${ }^{4}$.

Em seguida às primeiras ações da Universidade (com a criação do Museu Rondon, em 1971, e o MACP, em 1974) e da Fundação Cultural do Estado de Mato Grosso (com a Casa do Artesão, em 1975, e a Pinacoteca Estadual, em 1976), surgiram propostas fora da esfera dos governos, que também adotaram o mote da defesa e da preservação dos costumes e das tradições locais. Um destes movimentos foi o movimento Muxirum Cuiabano, fundado em abril de 1984 por uma parcela da elite local conhecida pelo nome de Cuiabania. Inspirada nos tradicionais mutirões dos trabalhadores do campo, que prestavam auxílio mútuo em suas roças e faziam festa, a proposta desta associação era a de promover apresentações artísticas e festividades representativas da cultura da baixada cuiabana, como uma forma de resistência à crescente presença do tradicionalismo dos imigrantes sulistas e nordestinos no Estado $^{5}$. Para isso, incentivavam o cultivo de costumes antigos, como a culinária, as danças e o linguajar dos ribeirinhos, entre tantos outros.

Outra iniciativa no mesmo sentido foi projeto Rua do Rasqueado, criado em 1993 pelo músico Milton Pereira de Pinho, o Guapo, com o apoio da Secretaria de Estado da Cultura e de empresas privadas. Percebendo que havia ainda enorme interesse da população pelo Rasqueado Cuiabano, gênero musical caracterizado pela mescla do Siriri com a polca paraguaia, muito dançado nos bailes e festas da periferia, Guapo passou a promover shows gratuitos na Praça Caetano Albuquerque, transformando os encontros em eventos de massa que incluíam a produção e

\footnotetext{
${ }^{4}$ PAZ, Vanessa Carneiro da. Encontros em defesa da cultura nacional: o Conselho Federal de Cultura e a regionalização da cultura na ditadura civil-militar (1966-1976). Dissertação de mestrado. Niterói-RJ: UFF/ICHF, 2011, p. 117.

${ }^{5}$ O Movimento Muxirum Cuiabano foi principalmente uma resposta deste segmento à larga difusão dos Centros de Tradições Gaúchas e dos Centros de Tradições Nordestinas em Mato Grosso. Um de seus dirigentes foi o apresentador Ulisses Calhão, que promovia a cultura cuiabana em seu programa de TV. 0 Muxirum Cuiabano foi reconhecido como uma associação de utilidade pública pela Lei Estadual $n^{\circ} 5830$ de 20 de setembro de 1991. Cf. SANTOS, Giordana Laura da Silva. O siriri na contemporaneidade em Mato Grosso: suas relações e trocas. Dissertação de mestrado. Cuiabá: UFMT/IL/ECCO, 2010, p. 25
} 
comercialização de $\mathrm{CDs}^{6}$. Estas experiências prepararam o terreno para a criação em 2001 do Festival de Siriri e Cururu de Mato Grosso por produtores independentes apoiados pelo Conselho Municipal de Cultura de Cuiabá. O Festival foi criado com a proposta central de reunir os principais grupos folclóricos do Estado, proporcionando maior visibilidade à sua atividade, orientando-a no sentido da profissionalização. 0 evento abriga hoje mais de 20 associações e grupos folclóricos de todo o Estado, promovendo não só os shows das três noites da mostra como também oferecendo apoio no acesso a fontes de financiamento e elaboração de projetos. A partir 2005, juntaram-se ao projeto duas novas atrações: o Festival Gastronômico Sabor \& Arte e a Feira de Artesanato, tornando-se assim o maior evento de massa decorrente da política para a cultura popular no Estado7.

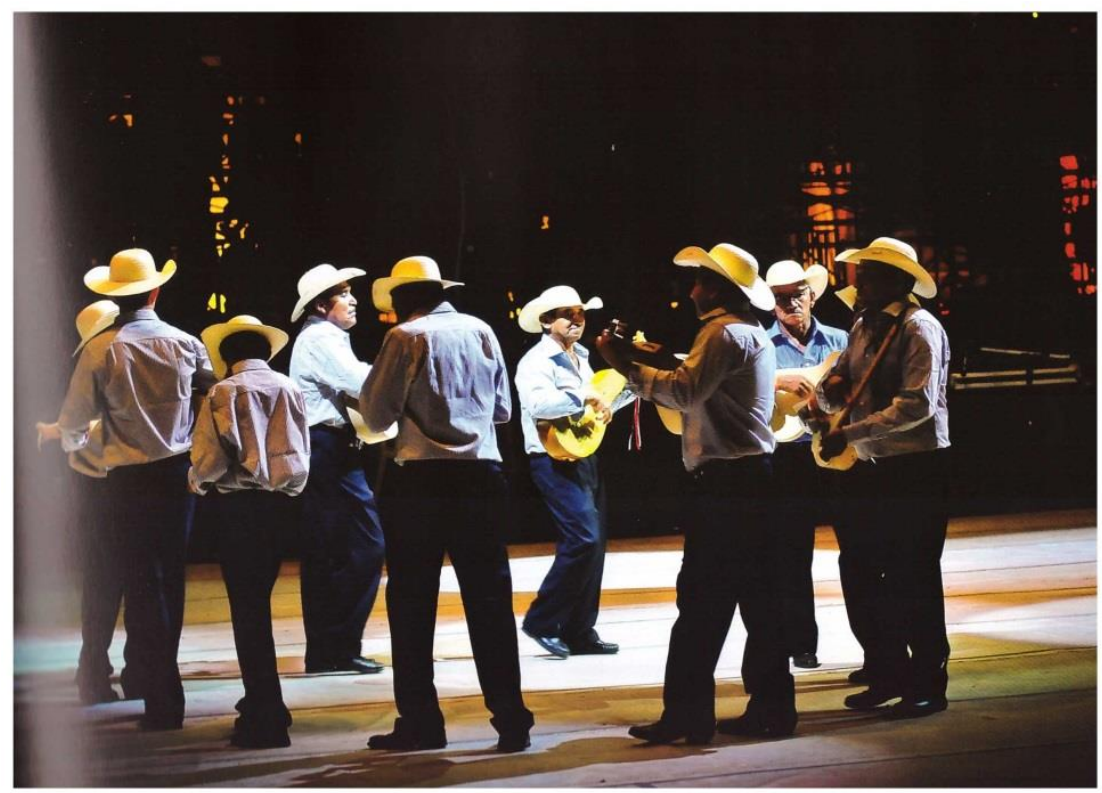

Figura 2: cururueiros no Festival Fonte: Loureiro, 2006

Ainda que a análise dos exemplos selecionados identifique nas ações políticas da década de 1970 o impulso inicial para a viabilização de um projeto específico para a cultura em Mato Grosso, o da legitimação de expressões das camadas populares, é importante ressaltar que algumas das discussões mais consistentes em torno da construção de uma identidade coletiva regional são percebidas através de uma

\footnotetext{
${ }^{6}$ MORENO, Vanessa. Guapo, na vanguarda do rasqueado. Diário de Cuiabá, DC Ilustrado. Publicado em : 21/01/2015. Disponível em:< http://www.diariodecuiaba.com.br/detalhe.php?cod=465022 > Acesso em: 24/04/2015.

7 PREFEITURA MUNICIPAL DE CUIABÁ. Catálogo do 8o Festival Siriri Cururu. Cuiabá: Central de Texto, 2009.
} 
cronologia mais ampla. Um dos momentos cruciais neste processo acontece, segundo Lylia Galleti, entre os anos 1918-1922, quando são criados o Instituto Histórico de Mato grosso - IHMT (1919) e o Centro Mato-grossense de Letras - CML (1921). A narrativa produzida por estas instituições irá enfatizar as riquezas naturais da província e os feitos de alguns dos personagens que foram alçados à condição de heróis da história de Mato Grosso. São eles o administrador colonial Luiz de Albuquerque Pereira e Cáceres, o bandeirante Paschoal Moreira Cabral, o governante e combatente na Guerra do Paraguai Augusto Leverger e, mais recentemente, o sertanista Cândido Rondon ${ }^{8}$.

0 ano de 1919 viverá também as comemorações do bicentenário da fundação de Cuiabá, com a figura do seu arcebispo emérito D. Francisco de Aquino Correia ocupando o mais alto posto político no Estado e participando ativamente da produção intelectual das referidas instituições ${ }^{9}$.

Baseada no ideário do bandeirantismo paulista, a influência do IHMT na formação identitária de Mato Grosso significou obviamente uma continuidade do discurso do desbravamento dos sertões como motor do desenvolvimento da região e estendeu-se a outros períodos. Assim, a Marcha para o Oeste, empreendida no período do Estado Novo da era Vargas, cerca de duas décadas após o governo de Don Aquino, valeu-se do legado indianista de Cândido Rondon - pioneiro na integração dos vazios demográficos da região através dos telégrafos e no contato cordial com várias etnias nativas - e da contribuição etnográfica de Edgar Roquette-Pinto - que à época, como um dos intérpretes da mestiçagem brasileira, advogou o progresso técnico e material dos habitantes de áreas isoladas - ambos influenciando na estratégia de povoamento e progresso econômico para o centro-oeste brasileiro ${ }^{10}$.

\footnotetext{
${ }^{8}$ GALETTI, Lylia da Silva Guedes. Sertão, fronteira, Brasil: imagens de Mato Grosso no mapa da civilização. Cuiabá: EdUFMT, 2012, p. 340-1.

${ }^{9} \mathrm{Em}$ 1918, D. Francisco de Aquino Correia foi nomeado governante de MT como solução conciliadora para um dos momentos políticos mais instáveis do período da Primeira República, marcado pelas disputas entre as forças ligadas ao Cel. Pedro Celestino Corrêa da Costa e o grupo ligado ao governo de Caetano de Albuquerque. Além de clérigo e político, foi também o mais importante intelectual mato-grossense de seu tempo, participando da fundação do IHMT, do CML e da criação do hino e do brasão do Estado. Como poeta e escritor, Don Aquino foi também o primeiro mato-grossense eleito para a Academia Brasileira de Letras. Cf. SIQUEIRA, Op. cit., p. 162.

${ }^{10}$ RANGEL, Jorge Antonio. Edgard Roquette-Pinto. Coleção Mec Educadores. Recife: FJN/Massangana, 2010, p. 12.
} 
Esta foi também uma fase preliminar à exploração econômica da Amazônia na década de 1970, implementada através do Plano de Integração Nacional (PIN), que previa o povoamento da região através da expansão da fronteira agrícola e da abertura de grandes eixos rodoviários.

Mais recentemente, com a superação da imagem de província distante dos principais centros urbanos para a condição de portal para a ocupação econômica da Amazônia e carro-chefe do negócio agropecuário no Brasil, novos referenciais de cultura se firmaram em Mato Grosso, trazidos tanto pelos novos moradores quanto pela maior penetração da cultura de massa. Referenciais que acabaram por se confrontar e se acomodar aos valores vigentes, fazendo com que algumas das práticas tradicionais do Estado se deslocassem dos seus meios e ocupassem novos palcos. Destas atuais conquistas de espaços na cena cultural local pela tradição, sobressaem os festivais de dança, os seminários e mostras de cultura e as feiras de artesanato, em grande medida, promovidas nos meios de comunicação e orientadas pela sua viabilidade econômica.

Canclini observa nas sociedades latino-americanas que foram vários os ramos do folclore que se expandiram nas últimas décadas, em razão do fomento à produção e ao comércio de bens culturais, com linhas de créditos, verbas de patrocínios e premiações concedidas a artesãos, músicos, dançarinos e poetas populares, entre outros. Os Estados também passaram a destinar cada vez mais recursos para a conservação e difusão destes bens culturais, através da abertura de museus e espaços de espetáculos populares, assim como a edição e criação de circuitos de vendas para livros, filmes e fonogramas ${ }^{11}$. Esses investimentos propiciaram, segundo o autor, a entrada em cena de atores provenientes de diferentes meios e variadas etnias, contribuindo para que as tradições se reinstalassem para além dos seus nichos originais, "em um sistema interurbano e internacional de circulação cultural" 12. Igualmente, observa-se um fenômeno identificado nos estudos de Hall como o da gestação de "novas identidades híbridas", fruto da crescente homogeneização cultural atual que ocorre em função do declínio das identidades locais, diretamente afetadas

\footnotetext{
${ }^{11}$ CANCLINI, Nestor Garcia. Culturas híbridas: estratégias para entrar e sair da modernidade. São Paulo: Edusp, 2013, p. 217.

12 Ibidem, p. 218.
} 
pelo processo de globalização e que, por isso mesmo, valorizam cada vez mais o regional e o comunitário ${ }^{13}$. A música folclórica da Baixada Cuiabana e partes velhas do Pantanal, da qual faz parte o Cururu mato-grossense, é uma das práticas que exemplifica este cultivo dinâmico do popular na modernidade tardia vista por Canclini e Hall, determinado não apenas pelas questões relativas à manutenção de sua identidade e o resgate da tradição, mas também pelas condições de comunicabilidade e inserção econômica nos novos cenários.

Neste capítulo, analiso o papel da política na formação de uma identidade local, levando em conta as escolhas feitas pelos seus agentes no sentido de privilegiar, a partir de um determinado momento, a temática rural e as representações culturais oriundas das suas populações ribeirinhas. 0 enfoque escolhido são as expressões em música desta tradição, o Cururu e o Siriri mato-grossenses. Para tanto, discuto o modo como são formulados estes discursos legitimadores e relaciono-os à criação de novos espaços para o popular (os festivais, os eventos de turismo, os programas televisivos, os cursos e as mostras em museus e casas de cultura). Também busco estabelecer analogias com algumas das práticas contemporâneas do Cururu em São Paulo, hoje presentes nos torneios de cantadores do Médio Tietê e no mercado fonográfico, como um subgênero da música caipira. Outro aspecto abordado são as propostas de diálogo entre estilos, com experiências na música de concerto e nas diversas vertentes musicais da cultura de massa (o pop-rock, a música de raiz e os gêneros "brega", entre outros), onde o popular se comunica com novos públicos através dos músicos da Orquestra de Mato Grosso, dos compositores de formação erudita como Abel dos Anjos e Roberto Victorio, além dos roqueiros da banda Strauss e dos cantores de Rasqueado Henrique, Claudinho e Pescuma. Por fim, reflito sobre a representação da viola-de-cocho como principal símbolo da cultura em Mato Grosso, analisando não só o seu status de patrimônio cultural do Estado, como também o emprego de sua imagem para além do sentido musical, nas artes visuais e na publicidade, com a consequente saturação de uma mensagem disseminada na forma de clichês ${ }^{14}$.

\footnotetext{
${ }^{13}$ HALL, Stuart. A identidade cultural na pós-modernidade. Rio de Janeiro: DP\&A, 2006, p. 69.

${ }^{14}$ GUIMARÃES, Op. cit., p. 26.
} 


\section{CURURU E SIRIRI}

Edson Carneiro, ao relatar em 1960 os folguedos tradicionais da região, comentava que um dos aspectos diferenciais do Cururu mato-grossense em relação ao seu congênere paulista era a sua proximidade com a dança do Siriri15. Sendo mais diretamente ligado aos festejos religiosos populares, o Cururu local tinha como uma de suas singularidades o fato de ser dançado e cantado apenas por homens, constituindo a sua prática numa das obrigações da fé tradicionalmente reservada aos mais velhos da comunidade. O Siriri, por sua vez, correspondia inteiramente à parte profana da festa, sendo dançado em pares, por homens e mulheres nos bailes dos aniversários, casamentos, batizados, festas de santos e até mesmo nas comemorações do carnaval. A respeito desta diferenciação, o cururueiro Francisco Salles nos oferece o seguinte comentário: "Siriri é fim de festa... o símbolo da festa é o Cururu" ${ }^{16}$. 0 mesmo observava Max Schmidt, em um dos registros pioneiros dos folguedos, acrescentando que o Cururu era dançado dentro de casa, enquanto o Siriri acontecia fora dela, "acompanhado também por música e versos cantados" 17.

Embora os principais instrumentos musicais que acompanham os dois exemplos sejam a viola-de-cocho e o ganzá, um diferencial importante neste aspecto é que no Siriri participam também o mocho, um tamborete também usado como assento, cujo couro esticado é percutido com dois bastões de madeira (detalhe na figura 3), e, mais raramente, o já citado adufe e o tamboril, um pequeno tambor cilíndrico apoiado em pés de madeira normalmente feitos de cabos de vassoura ${ }^{18}$. A presença deste instrumental no Siriri indica o seu caráter mais rítmico e mais pulsante, enfatizado pelo emprego de um andamento mais rápido e a fórmula de compasso binário composto (6/8) para o acompanhamento rítmico da dança. Estes dois aspectos (instrumentação e andamento) são as prováveis explicações para a influência africana apontada no folguedo. Roberto Loureiro, por exemplo, vê o Siriri como uma dança de características próximas às do Carimbó do Pará, composta de

\footnotetext{
${ }^{15}$ CARNEIRO, Edson. Folguedos tradicionais. Rio de Janeiro: Conquista, 1974, p. 78.

${ }^{16}$ Apud VIANNA, Letícia. Dossiê 8: modo de fazer viola-de-cocho. Brasília: Iphan, 2009, p. 57.

${ }^{17}$ SCHMIDT, Max. Estudos de etnologia brasileira: peripécias de uma viagem entre 1900 e 1901 . São Paulo: Cia. Ed. Nacional, 1942, p. 14.

${ }^{18}$ GRANDO, Beleni Saléte Grando. Cultura e dança em Mato Grosso. Cuiabá: Central do Texto, 2005, p. 40.
} 
elementos africanos, portugueses e espanhóis ${ }^{19}$, numa opinião próxima da defendida por Julieta de Andrade, que define o Siriri como uma dança "hispano-lusitana fortemente aculturada no ritmo e no andamento com a expressão africana bantu" 20. Observando os seus movimentos em roda e em fileiras opostas, Carneiro encontra semelhanças nos folguedos de origem portuguesa, como a Cana Verde paulista e o Caranguejo dos fandangos do centro-sul brasileiro, sem, no entanto, identificar maiores vínculos com as formas derivadas dos batuques de origem africana ${ }^{21}$. Giordana Santos, por sua vez, reúne em seu estudo alguns depoimentos de "brincantes" do Siriri que relacionam a sua origem aos seus ancestrais que eram índios, por causa da semelhança dos seus passos com o pateado característico de algumas danças aborígenes ${ }^{22}$. Ademais, o canto no Siriri tem o emprego de uma fórmula peculiar, em que o papel de músicos e dançarinos se assemelha à prática dos responsórios litúrgicos. Neste tipo de prática, o trecho solista se alterna com a sua resposta, que deve ser cantada por um coro ou pela congregação. No caso do Siriri, os versos da primeira parte da estrofe entoados pelos cantadores são respondidos no último verso por um coro maior formado pelos dançarinos, podendo as estrofes ser repetidas ad aeternum, enquanto durar o fôlego e a animação dos participantes ${ }^{23}$. A seguir, a toada Nandaia, cantada Francisco Salles, Dorílio da Silva, Bonifácio e o Grupo de Dona Marcolina, registrada em Cuiabá por Elisabeth Travassos e Roberto Corrêa e transcrita em partitura por Edilberto Fonseca, ilustrando este formato (exemplo 1, faixa 8 do $\mathrm{CD}$ em anexo). A transcrição em dois pentagramas feita por Fonseca ressalta o diálogo no canto aqui descrito:

\author{
Nandaia, nandaia, \\ Vamos todos nandaiá (cantadores) \\ Meu padre Santo Antônio, \\ Venha me ensiná dançar (dançarinos)
}

\footnotetext{
${ }^{19}$ LOUREIRO, Op. cit., p. 84.

${ }^{20}$ ANDRADE, Julieta de. In: Cadernos de Cultura - Siriri. Cuiabá: Central de Texto, 2006, p. 10.

${ }^{21}$ CARNEIRO, Op. cit., p. 79.

22 SANTOS, Giordana Laura da Silva. O Siriri na contemporaneidade em Mato Grosso: suas relações e trocas. Dissertação de Mestrado. Cuiabá: UFMT, 2010, p. 19. Generalizações como esta são recorrentes na conceituação de expressões populares brasileiras, simbolizando no canto e na dança a noção do caldeamento das três raças, bastante explorada nos discursos sobre a identidade cultural brasileira da segunda metade do século XIX e início do XX. Cf. ORTIZ, Renato. Cultura brasileira e identidade nacional. São Paulo: Brasiliense, 2012, p. 19.

${ }^{23}$ VIANNA, 2009, Op. cit., p. 57.
} 
Põe esta perna (cantadores)

Se não servir esta, (dançarinos)

Põe esta outra

Pra senhora moça

Arrodeia, arrodeia, arrodeia (cantadores)

Fica de joelho (dançarinos)

Põe a mão na cintura

Pra fazê misura
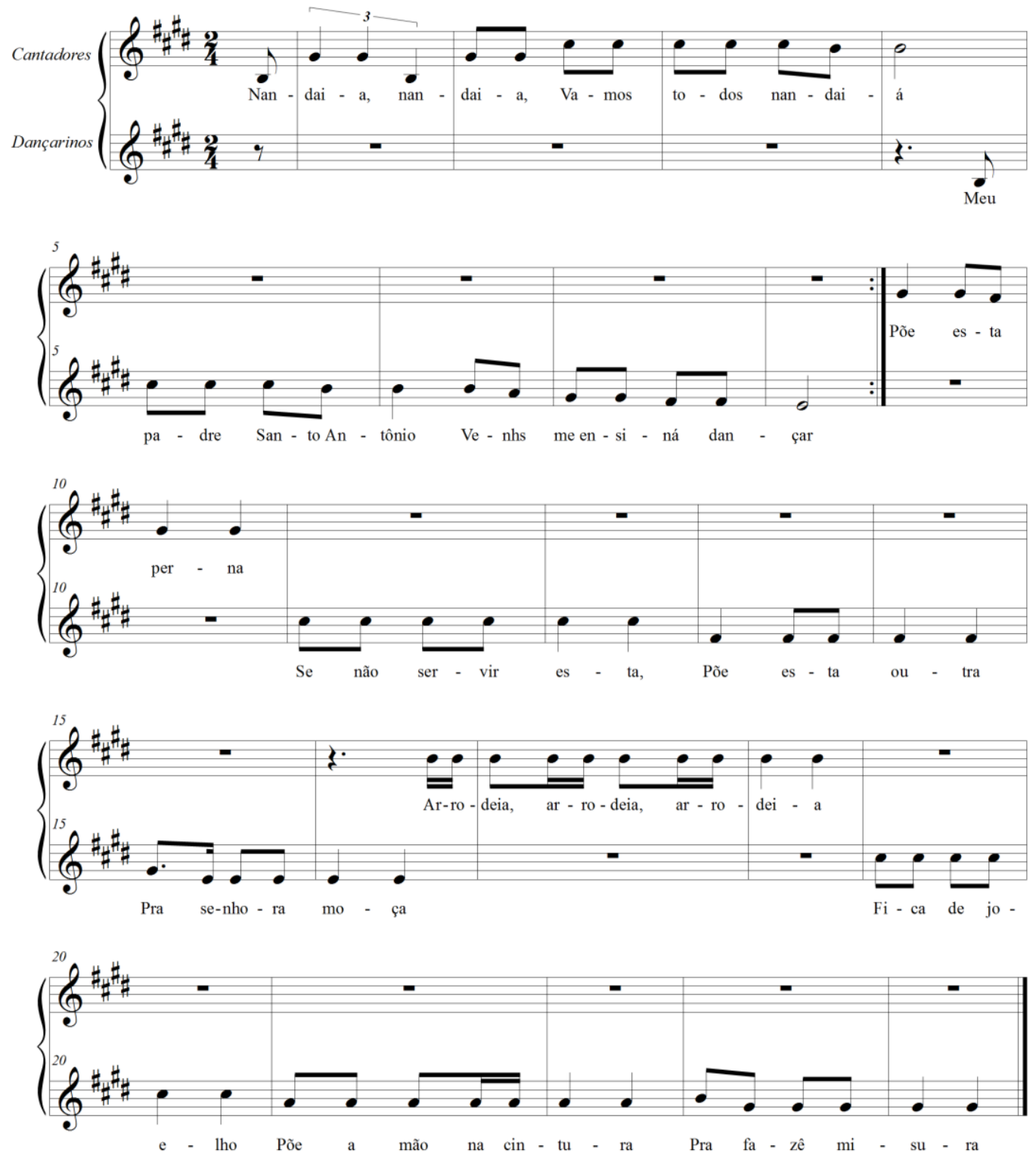

Exemplo 1: Nandaia

(Grupo de Siriri de Dona Marcolina)

Fonte: Travassos, Corrêa e Fonseca, 2009 
Outro exemplo que segue o mesmo formato responsorial é cantado por Seu Tuti, cururueiro do município de Chapada dos Guimarães, transcrito na ocasião em que estive em sua pequena fazenda, em junho de 2012 (exemplo 2, faixa 9 do CD em anexo). Nesta toada, a temática ao mesmo tempo profana e religiosa pode ser entendida como um elemento a mais de proximidade entre as danças do Cururu e do Siriri, conforme a já citada afirmação de Carneiro.

Eu passei a ponte d'água que bebeu, (cantadores)

Água tem veneno, eu não te vi e morreu... (dançarinos)

Tem a Quinta-feira Santa, Sexta-feira da Paixão, (cantadores)

Tem o Sábado d'Aleluia, Domingo da (Res)surreição. (dançarinos)
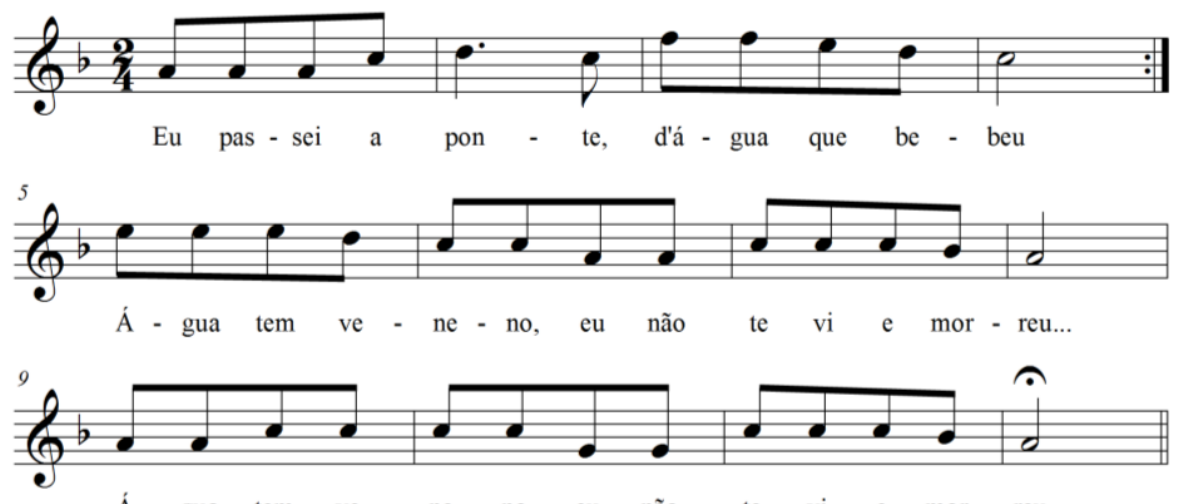

Á - gua tem ve - ne - no, eu não te vi e mor - reu...
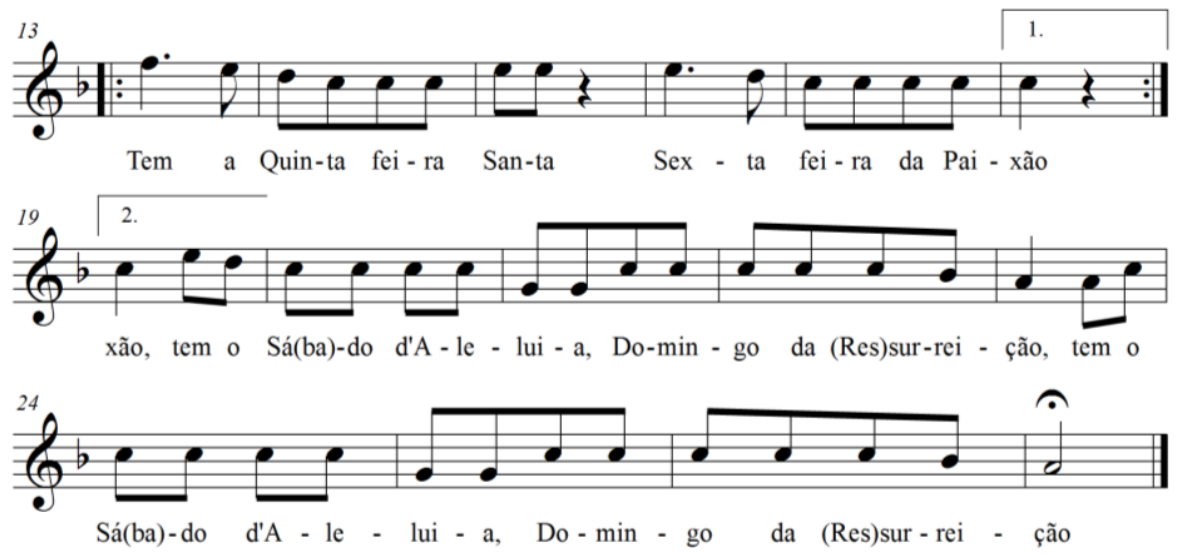

Exemplo 2: Toada de Siriri

(Seu Tuti, de Chapada dos Guimarães)

Fonte: o autor 
Além destes aspectos citados no Siriri - a participação de homens e mulheres na dança, o andamento movido, maior variedade de instrumentos de percussão e o canto responsorial - há também alguns recursos de efeito cênico, que foram introduzidos em suas práticas contemporâneas e que tornaram o gênero ainda mais atrativo para o formato atual dos espetáculos e das mostras de folclore. As principais mudanças experimentadas no Siriri foram os figurinos coloridos (com destaque para as saias rodadas das mulheres), os efeitos de iluminação do palco e as coreografias repetidamente ensaiadas por profissionais. Muitos dos cururueiros que também passaram a apresentar a sua arte nas mostras e festivais de cultura popular adequaram-se às tendências mais recentes, adotando o figurino uniformizado. Porém, mantiveram-se mais contidos em relação aos praticantes do Siriri, conforme veremos a seguir, nas descrições do festival que leva os seus nomes.

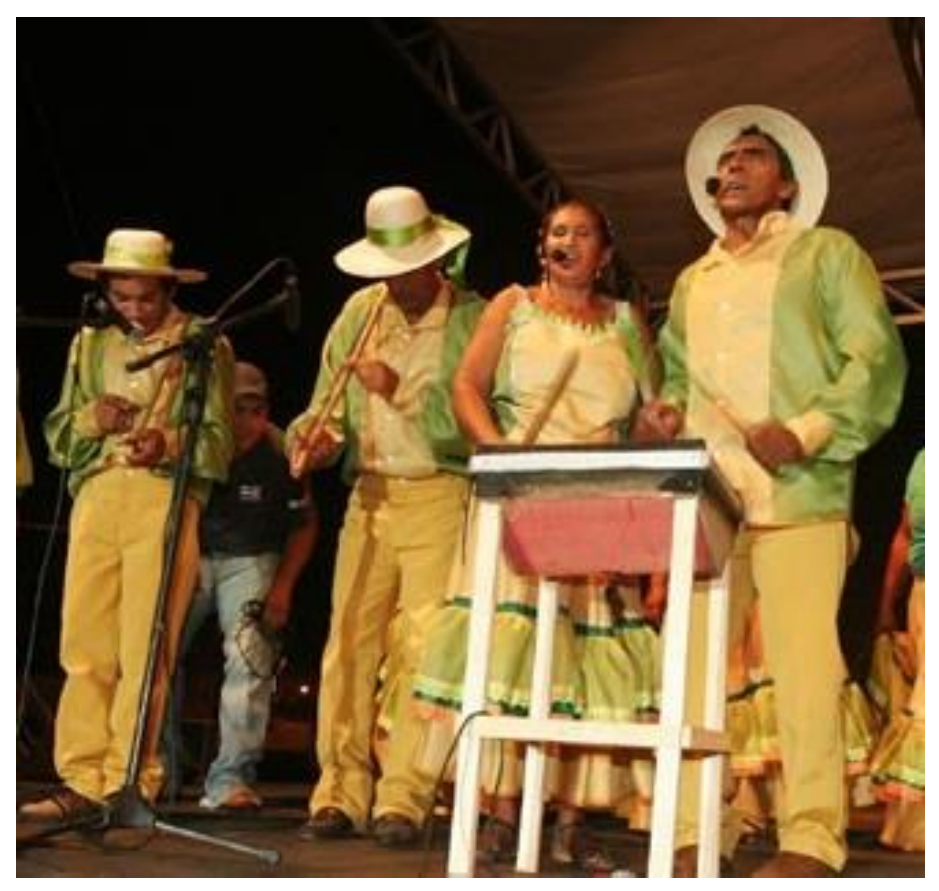

Figura 3: tocadores de mocho e ganzá no Festival Fonte: Leonor, 2015

\section{O FESTIVAL}

Para Sílvia Ramos Bezerra, neste novo desenho da região, a principal disputa entre o pensamento ligado à força econômica do imigrante e o tradicionalismo local da Cuiabania se dará através das representações culturais, sendo um lado simbolizado através dos centros de compras e dos edifícios residenciais modernos e o 
outro pelos prédios históricos tombados, o artesanato e as iguarias locais ${ }^{24}$. É interessante notar, no entanto, que a partir de um determinado momento partirá de ambos os polos a necessidade de um projeto político único: o de se reverenciar a vida simples rural por meio dos valores tomados dos antigos ribeirinhos ${ }^{25}$. Esta busca de um referencial comum é também perceptível na fala dos representantes da política. Em campanha para reeleição à prefeitura de Cuiabá, em 2008, o político matogrossense Wilson Santos, nascido na cidade paulista de Dracena, reserva para o final de sua participação em debate televisivo a seguinte pergunta a um de seus oponentes: "qual a diferença entre o Siriri e o Cururu?" Não obtendo resposta, o então prefeito reforça em definitivo a mensagem de que é o melhor candidato justamente por "conhecer" a cultura do seu povo. ${ }^{26}$ Em outra campanha, em 2010, o então candidato a senador Pedro Taques critica o uso por parte de seu adversário de um determinado tema musical em seu programa televisivo, comentando que, mesmo apreciando o som do violino usado na propaganda rival, sua preferência deveria obedecer ao seu coração nativo, ficando com os acordes da viola-de-cocho ${ }^{27}$.

Rememorando a militância de movimentos como o Muxirum Cuiabano, que nos anos 80 e 90 organizou festas, exposições e produziu programas de TV, não é exagero afirmar que esta elite local se ocupou prioritariamente da tarefa de criar um gosto unívoco pelo popular. Neste novo culto, que Certeau descreveu como uma necessidade das elites de "uma restauração da vida provinciana", como antídoto para o distanciamento e para os enganos do refinamento moderno, residiria também "um populismo dos poderosos, em busca de uma nova aliança" ${ }^{28}$. É neste contexto que o Festival de Cururu e Siriri de Cuiabá irá se firmar como o maior evento de cultura popular no Estado.

\footnotetext{
${ }^{24}$ BEZERRA, Sílvia Ramos. Contradições Culturais do Cortejo Triunfante da Modernidade em Mato Grosso. Fênix - Revista de História e Estudos Culturais. Jul a Set 2008, vol. 5, Ano V, n. 3, p. 11. 
O Festival surgiu de um conjunto de propostas elaboradas em 2001, pelo Conselho Municipal de Cultura, na gestão do então prefeito Roberto França, que previa as seguintes ações de apoio à cultura local:

1. Promover o intercâmbio entre os grupos folclóricos.

2. Organizar um grande chamado destes grupos, com patrocínios e publicidade, na forma de um festival temático.

3. Coordenar a instalação de oficinas culturais e cursos.

4. Apoiar ações de pesquisa sobre as manifestações folclóricas da região.

Estas diretrizes constavam do projeto elaborado por um de seus conselheiros, o produtor cultural Valdemir Taques, que oficializaram a criação do Festival, tendo a sua primeira edição realizada já no ano seguinte ${ }^{29}$. Além do poder público, na figura do seu secretário municipal de cultura, Ilton Severino da Silva, participaram da organização do evento alguns dos agentes culturais ligados a grupos de dança - Dilza Catarina Souza da Silva e Valeriano Nepomuceno, membros do grupo Flor do Campo; Domingas Leonor da Silva, fundadora do grupo Flor Ribeirinha; Valdemir Taques, do grupo Tchapa y Cruz e o casal Francisco e Mara Sales, do grupo Viola-de-Cocho - que se juntaram para formar à época a Federação das Associações dos Grupos de Siriri e Cururu. Estes foram, aliás, os quatro grupos que se apresentaram na primeira edição do Festival ${ }^{30}$.

Vale ressaltar que o projeto do Festival foi também o resultado de um conjunto de ações da administração municipal de Cuiabá com produtores culturais independentes, iniciado ainda nos anos 80. A partir do contato com algumas das práticas espontâneas do Siriri e do Cururu em comunidades ribeirinhas de Cuiabá e Santo Antônio de Leverger, o historiador e professor da UFMT Carlos Alberto Rosa, àquela época chefiando o Departamento de Cultura e Turismo da prefeitura de Cuiabá (DCT), iniciou importante levantamento documental sobre as manifestações tradicionais mato-grossenses, contribuindo para a criação do movimento Muxirum Cuiabano e da Associação Folclórica de Mato Grosso, em 1982, que mais tarde se tornou a Federação das Associações de Grupos de Cururu e Siriri de Mato Grosso.

\footnotetext{
${ }^{29}$ SANTOS, Op. cit., p. 93-4.

${ }^{30}$ Ibidem, p. 94-5
} 
Nos anos 80, na gestão do prefeito Anildo Lima Barros, foram realizadas as primeiras "festas de cururu e siriri" nos aniversários de Cuiabá, sob o auspício de uma lei municipal de autoria do vereador Euclides Maciel. Foi quando o DCT resgatou o cururueiro Luiz Marques, um entusiasta que acabou fundando a Associação Folclórica de Mato Grosso (AFOMT), entidade que, mesmo com seus altos e baixos, de lá pra cá, foi a propulsora da divulgação e resgate (sic). E hoje temos o Festival de Cururu e Siriri, graças a esse trabalho de mais de 30 anos $^{31}$.

Uma das principais ações do DCT em conjunto com a AFOMT foi a promoção de visitas a municípios do Estado, com o objetivo de fomentar a criação de novos grupos de dança. Segundo Giordana Santos, cururueiros e gestores destes grupos folclóricos formaram uma comitiva que percorreu, na década de 1990, lugares que ainda mantinham vivo o cultivo de seus folguedos tradicionais, como os municípios de Santo Antônio de Leverger, Nossa Senhora do Livramento e Poconé. Também visitaram localidades como Diamantino, Barra do Bugres, Barão de Melgaço e Juara, que guardavam na memória de seus moradores práticas tradicionais que começavam a cair em desuso, além das cidades que se formaram a partir da expansão do agronegócio e tiveram a sua população formada na maioria por sulistas, como no caso do município de Nova Mutum ${ }^{32}$. 0 testemunho de Dilza Catarina de Souza Silva, diretora do grupo Raízes Cuiabanas, ilustra as ações da comitiva itinerante da AFOMT, cujo objetivo era fazer com que cada município pudesse ser representado no Estado através de agremiações de dança folclórica, mesmo tendo a localidade que abraçar uma cultura que era estranha à maioria de seus moradores. Dona Dilza conta a Giordana dos Santos que eram muitos os lugares onde poucos conheciam o Siriri, "a maior parte de sulista, que não valorizava a cultura" 33 . Os resultados desta política puderam ser aferidos quase duas décadas mais tarde, com o sucesso do grupo Pixé de Nova Mutum em várias edições do Festival, motivando a fala entusiasmada do prefeito de Cuiabá Wilson Santos, que em 2009 disse:

Ver Nova Mutum, cidade criada por gaúchos, paranaenses e catarinenses, totalmente sulista, se entregar ao Cururu e Siriri, é

\footnotetext{
${ }^{31}$ BOSQUO, João. Para quem não sabe o que é Cururu e Siriri. Webblog publicado em 10/10/2008. Disponível em: < https://jbas.wordpress.com/2008/10/10/para-quem-ainda-no-sabe-cururu-e-siriri/> Acesso em: 12/04/2015.

${ }^{32}$ SANTOS, Op. cit., p. 38.

${ }^{33}$ Apud, Idem.
} 
emocionante. A cultura pantaneira pode integrar o Estado. É religiosa e tem mais de 300 anos $^{34}$.

O desejo traduzido na fala do prefeito de Cuiabá de uma integração da extensa província de Mato Grosso por meio da cultura popular pode ser visto em paralelo ao projeto oficial das repúblicas europeias que se organizaram no século XIX por meio de uma política de massas, valendo-se da invenção ou do reposicionamento das tradições como instrumento de coesão social ${ }^{35}$. A respeito dessa estratégia, o historiador britânico Eric Hobsbawm explica:

Mais interessante, do nosso ponto de vista, é a utilização de elementos antigos na elaboração de novas tradições inventadas para fins bastante originais. Sempre se pode encontrar, no passado de qualquer sociedade, um amplo repertório desses elementos; e sempre há uma linguagem elaborada, composta de práticas e comunicações simbólicas [...], modificadas, ritualizadas e institucionalizadas para servir a novos propósitos nacionais ${ }^{36}$.

Tanto os exemplos europeus estudados por Hobsbawm, onde costumes, personagens, efemérides e demais representações cívicas dadas como antigas foram construídas ou reorientadas em razão de uma política para o futuro, quanto a experiência de Nova Mutum, que concentrou suas ações na viabilidade dos jovens estudantes se interessarem pela dança tradicional dos moradores da Baixada Cuiabana e Pantanal, carregam o propósito do fortalecimento de referências a um passado (estranho, para alguns) que deverá ter uma continuidade e servir a novos fins.

Neste processo de ressignificação das práticas do Cururu e do Siriri, diversas mudanças foram gradativamente adotadas nas performances do Festival. Aos sons dos instrumentos característicos das duas danças tradicionais, foram acrescidos o violão, o teclado e o acordeon, quando trechos de outros gêneros passaram a ser

\footnotetext{
${ }^{34}$ Apud AURÉLIO, Max. Grupo Pixé de Nova Mutum é destaque em MT. Weblog publicado em 21/09/2009. Disponível em: $<$ http://www.jonalterritorios.com/2009/09/grupo-pixe-de-nova-mutum-e-destaqueem.html > Acesso em: 12/04/2015.

${ }^{35}$ HOBSBAWM, Eric. A produção em massa de tradições: Europa, 1870 a 1914. In: HOBSBAWM, Eric. \& RANGER, Terence (org.) A invenção das tradições. São Paulo: Paz e Terra, 1977, p. 276.

${ }^{36}$ Ibidem, 14.
} 
executados juntamente com as toadas de Siriri. Este recurso passou a fazer parte das apresentações dos grupos inscritos no Festival, conforme explica Lopes:

No evento os grupos são livres para executar qualquer gênero musical - em algum dos vários momentos de suas performances mas a maior parte da apresentação é formada de cantigas tradicionais de Siriri acompanhadas do mocho, da viola de cocho e do ganzá. Praticamente todos os grupos que se apresentaram no 8o e 9o Festival Cururu Siriri tocaram músicas de outros gêneros, como gospel, pop, vaneirão, baião, xaxado, entre outros gêneros musicais ${ }^{37}$.

A partir da transposição do folguedo para o palco, o figurino passou a ser um item obrigatório na prática do Siriri, com o desenho das roupas, a textura, as estampas e o brilho dos tecidos selecionados em função do tema representado a cada ano ou das cores representativas do grupo. Para o traje feminino as saias se tornaram cada vez mais rodadas e com muitos babados. Já para os homens, o tecido padronizado das camisas passou a ser o mesmo empregado nos vestidos das dançarinas; em outros casos, apenas harmonizando suas cores com o figurino feminino ${ }^{38}$. A dança com os pés descalços, que era uma das características dos festejos tradicionais da área rural, continuou a ser uma marca de alguns dos grupos que se apresentam no Festival; porém, os calçados também foram naturalmente incorporados aos figurinos ${ }^{39}$. Alguns acessórios se tornaram indispensáveis: as flores nos cabelos das mulheres, chapéus para os homens, a peneira enfeitada com fitas, lenços e faixas para ambos ${ }^{40}$. Com o Festival, os cururueiros passaram a cuidar também dos seus figurinos, buscando, porém, uma linguagem visual mais discreta e coerente com a vestimenta simples do cantador em seu ambiente original.

A dança do Siriri ganhou também novos contornos com a adição de elementos cênicos aos números apresentados. A principal inovação foi a Abertura - uma introdução à toada, com os dançarinos anunciando um determinado tema através de breve encenação. Um dos temas mais encenados na Abertura é o da procissão católica, com os dançarinos carregando para o palco o andor com a imagem do santo

\footnotetext{
${ }^{37}$ LOPES, Aaron Roberto de Mello. O Festival Cururu Siriri e seus impactos: espetacularização e inovação de duas tradições mato-grossenses. Anais do II SIMPOM, Rio de Janeiro: UNIRIO, 2012, 668-675, p. 673.

${ }^{38}$ SANTOS, Giordana Laura da Silva. Op. cit., p. 40.

39 Ibidem, p. 42.

${ }^{40}$ GRANDO, Op. cit., p. 42.
} 
homenageado e entoando cantos religiosos. Uma referência aos ritos praticados nas festas populares de santos da área rural. Outra novidade experimentada foi a incorporação de personagens à apresentação, podendo ser representados tipos pitorescos (como a sinhazinha da fazenda, a comadre do bairro, o ribeirinho, entre outros) ou de personagens lendários e animais (o minhocão, a mula-sem-cabeça, o boi-à-serra e a onça-pintada) ${ }^{41}$.

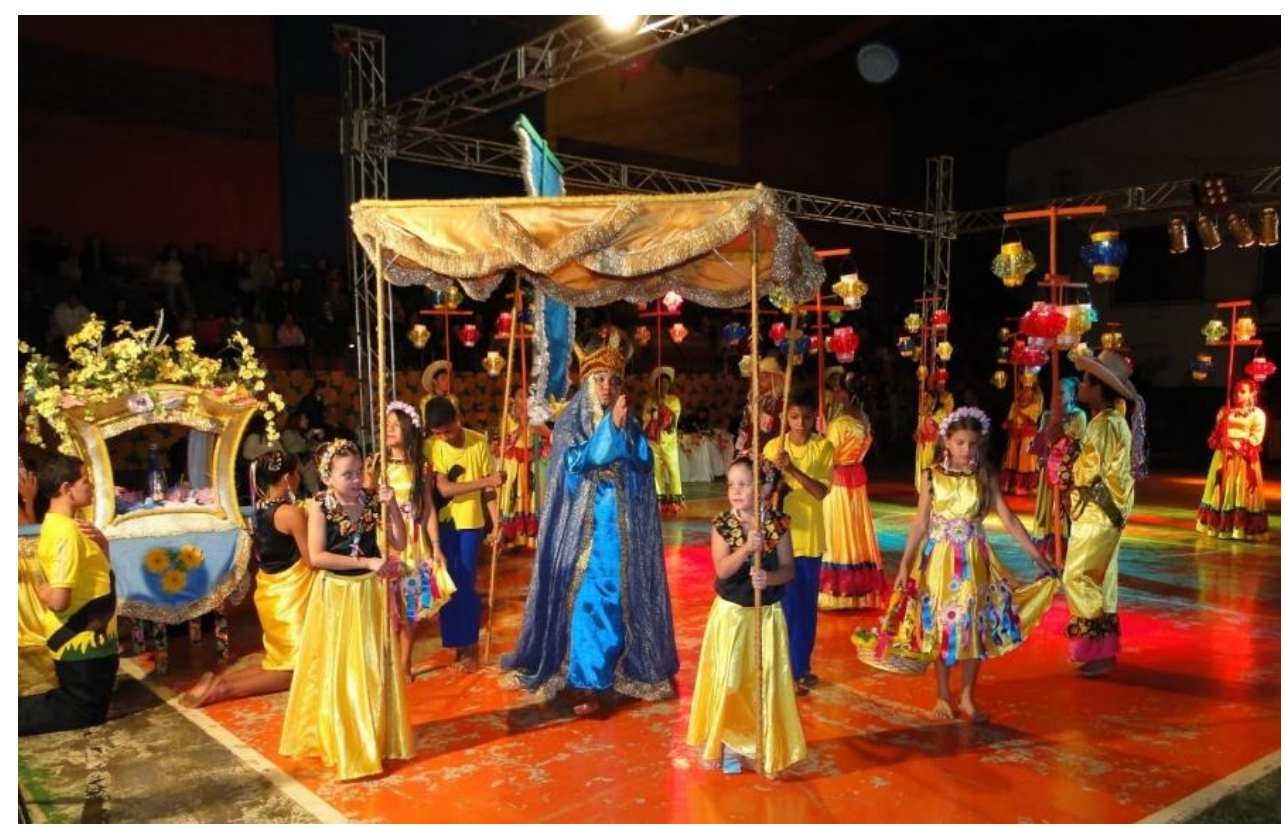

Figura 4: Abertura do grupo Pixé

Fonte: Leonor, 2015

A adição destes elementos às performances da mostra cuiabana tem evidente ligação com algumas manifestações tradicionais de outros estados brasileiros que adquiriram a dimensão e o caráter dos espetáculos de massa. Um dos eventos do tipo é o Festival de Paritins, no Amazonas, em que agremiações folclóricas encenam o ritual dos Bois Bumbás em uma grande arena ao ar livre, com músicas e alegorias representando costumes ribeirinhos, lendas e celebrações indígenas. A popularidade do Festival de Paritins ultrapassou os limites da região do Amazonas, com transmissão em rede de televisão nacional a partir da década de 2000. Em junho de 2007, a presidente da Federação das Associações de Grupos de Siriri e Cururu de Mato Grosso e diretora do grupo Flor Ribeirinha Domingas Leonor da Silva e representantes de outros grupos de Siriri viajaram, a convite do prefeito Wilson

\footnotetext{
${ }^{41}$ REIS, Rai; BARROS, Lidiane. Siriri e Cururu: explosão de ritmos e cores. Cuiabá: Carlini e Caniato, 2013, passim.
} 
Santos e do secretário de cultura Mário Olímpio, a Paritins para acompanhar in loco a festa amazonense e absorver as estratégias adotadas que fizeram dela um espetáculo midiático. Na ocasião, a assessoria de comunicação da Prefeitura informou:

O prefeito de Cuiabá, Wilson Santos, leva comitiva cultural para a tradicional Festa de Parintins, que ocorre neste final de semana em terras amazonenses. [...] É a primeira vez que estes representantes de grupos folclóricos de Cuiabá viajam para conferir o espetáculo. Para o prefeito Wilson Santos, a visita da comitiva a Parintins vai resultar em muitas ações positivas, como o intercâmbio entre os grupos folclóricos daqui com os da cidade do norte do país. "Ao conhecer os currais onde são produzidos os bois, figuras lendárias, a forma como se organiza e executa a festa, podemos trocar experiências e também divulgar o nosso Festival Cururu Siriri, que é a mais forte expressão folclórica da cultura popular mato-grossense", destacou o prefeito, acrescentando que a visita resultará em trabalhos de cooperação técnica entre as prefeituras. ${ }^{42}$

$\mathrm{Na}$ festa de Paritins, os grupos folclóricos disputam o título de melhor do ano em quesitos como coreografia, evolução, toada, apresentador, porta-estandarte, entre outros, sendo o clima de disputa entre o Boi Garantido e o Boi Caprichoso (as duas agremiações de maior destaque no evento) comparável ao da competição entre as escolas de samba do carnaval de cidades como Rio de Janeiro e São Paulo. No Festival de Siriri e Cururu de Cuiabá, os grupos de dança não competem entre si. Há, porém, um sistema de seleção dos grupos participantes através de apresentações prévias. Em 2007, uma comissão julgadora formada por membros da Federação passou a percorrer o Estado selecionando os melhores grupos, a "Caravana Roda Siriri e Cururu". Os quesitos avaliados pelos jurados foram: expressão corporal, harmonia, evolução, estética do grupo, conjunto, canto, criatividade, empolgação, ritmo e adereços $^{43}$. Em de 2011, estas prévias foram modificadas com a realização de quatro "mini festivais" chamados "Seminários Território Cururu e Siriri" nas seguintes regiões: Área I: Cáceres, Livramento e Poconé; Área II: Cuiabá, Várzea Grande, Chapada dos Guimarães e Planalto da Serra; Área III: Santo Antônio de Leverger e

\footnotetext{
${ }^{42}$ AGÊNCIA DE NOTÍCIAS DOS MUNICÍPIOS. Publicado em 29/06/2007. Disponível em: <http://www.lajeado.to.gov.br/003/00301009.asp?ttCD CHAVE=58649> Acesso em: 12/04/2015. ${ }^{43}$ REPÓRTER NEWS. Caravana Roda Cururu Siriri na estrada. Publicado em 22/05/2007. Disponível em: <http://www.reporternews.com.br/noticia/225920/Caravana_Roda_Cururu_Siriri_na_estrada_>Acesso em: 12/04/2015.
} 
Barão de Melgaço; Área IV: Nova Mutum, Rosário Oeste, Nobres, Jangada, Tangará da Serra e Barra do Bugres ${ }^{44}$. Segundo Santos, os próprios "brincantes" do Siriri reconhecem que o estabelecimento destes critérios de seleção transformou significativamente as práticas da dança, induzindo ainda mais os grupos à necessidade de "inovar", através da "teatralização" de suas performances ${ }^{45}$.

Em 2010, assisti a algumas apresentações da 9ạ edição do Festival, com o intuito de testemunhar sobretudo o espaço dado à prática do Cururu na programação geral do evento, visto que, naquele contexto, ela estaria despojada do seu sentido original de representação do sagrado. Além dos números apresentados no palco da Arena Cultural, foi montado um espaço para a exposição de peças do artesanato local simulando o ambiente tradicional do Cururu, a sala de uma residência ribeirinha em dia de festa de santo. Neste cenário, um altar foi posicionado ao centro, com as imagens de santos, velas, bandeiras e bandeirolas para que os grupos de cururueiros dessem uma mostra, em alguns minutos, da sua dança e sua cantoria. Um número limitado de ouvintes era autorizado a assistir aos cantadores nesta "sala" e assim os mesmos terminavam por entrar em cena várias vezes em uma mesma noite. Apesar do esmero nos detalhes, a impressão era a de que os organizadores do evento não puderam ali reproduzir o espírito de devoção vivido nas celebrações tradicionais da região. Não o suficiente para fazer com que os cururueiros se sentissem à vontade, como se estivessem em seus meios. Experiências como esta demonstram o modo como a religiosidade e a alegria da festa dão sentido à existência do Cururu.

\section{A VIOLA-DE-COCHO}

Em 2004, a viola-de-cocho foi registrada como patrimônio imaterial, no Livro dos Saberes do Instituto do Patrimônio Histórico e Artístico Nacional (IPHAN). A solicitação do registro ocorreu na forma de abaixo-assinados de moradores de vários municípios dos estados de Mato Grosso e Mato Grosso do Sul (muitos deles artesãos e

\footnotetext{
${ }^{44}$ REGULAMENTO DO 10 FESTIVAL CURURU SIRIRI. Publicado em 26/10/2011. Disponível em: $<$ https://10festivalcururusiriri.wordpress.com/2011/10/26/regulamento-do-10-festival-cururu-siriri/> Acesso em: 12/04/2015.

${ }^{45}$ SANTOS, Op. cit., p. 107-9.
} 
representantes de grupos de Cururu e Siriri), preocupados com a salvaguarda de expressões tradicionais ligadas ao instrumento. Foi uma petição que resultou também do interesse de membros da comunidade acadêmica, de artistas e de agentes dos órgãos oficiais de cultura, envolvidos na pesquisa, criação e promoção de mostras sobre o tema, fazendo com que esta aproximação do tradicional/popular com suas representações na academia e em outros meios elitistas traduzisse o anseio das autoridades por elevar seus símbolos ao status de cultura autorizada. Não importou o quanto se abusou de clichês para esta operação, pois a viola-de-cocho finalmente passou a ser cultuada como o símbolo maior da província ${ }^{46}$. Neste processo, várias disputas foram travadas entre seus próprios defensores. Em 1996, a Assembleia Legislativa de Mato Grosso aprovou o seu tombamento como patrimônio cultural do estado, atendendo ao clamor dos segmentos ligados à cultura local que se opunham a “uma tentativa de apropriação do registro da marca 'viola-de-cocho' junto ao Instituto Nacional de Propriedade Intelectual (INPI), por um estudioso de música de Cuiabá".47 Em Mato Grosso do Sul, processo análogo foi feito a partir dos resultados do projeto "Viola-de-cocho Pantaneira", criado em 2001 com recursos da empresa BR Distribuidora, despertando nos vizinhos mato-grossenses protestos como a do cururueiro e presidente da Associação Folclórica de Mato Grosso (AFOMT), Sr. Luiz Marques da Silva, que em reunião com políticos expressou sua "preocupação com o tombamento da viola-de-cocho, recentemente feito pelo estado vizinho Mato Grosso do Sul (que nunca mostrou nenhum trabalho com o instrumento)" 48.

Ao lado da etnografia de Julieta de Andrade, Abel dos Anjos Filho e Edgar Roquette-Pinto, o cururueiro Luiz Marques foi também um dos formuladores das recentes narrativas que buscaram territorializar símbolos culturais como a viola-decocho. Andrade e Anjos Filho apontaram em suas pesquisas a origem árabe e europeia do instrumento, tendo o mesmo se regionalizado em seus materiais, feitio e

\footnotetext{
${ }^{46}$ ROCHA, Anderson. A viola-de-cocho como símbolo das tradições em um novo Mato Grosso. Anais do $V$ Simpósio Internacional de História. Goiânia: Anpuh/UFG, 2011, p. 3.

${ }^{47} \mathrm{O}$ "estudioso de música" citado é Abel dos Anjos Filho, professor da UFMT. Ele se defende afirmando que nunca pretendeu patentear a viola-de-cocho, apenas abrir uma firma de eventos com o nome que, segundo o músico e professor, é patrimônio de todos. In: VIANA, Letícia. “O caso de registro da viola-de-cocho como patrimônio imaterial”, in Sociedade e Cultura. Goiânia: UFG, V. 8 N. 2, 2005, p.61.

${ }^{48}$ GUAPO, Milton Pereira de Pinho. Remedeia co que tem. Cuiabá: Carlini \& Caniato, 2010, p. 40.
} 
modo de tocar, tornando-se endêmico do Pantanal e Baixada Cuiabana ${ }^{49}$. RoquettePinto reafirmou este regionalismo, explicando-o inclusive através de sua pronúncia: "Cotcho - voz cuiabana do vocábulo cocho" 50. Ao falar em nome dos cururueiros de Mato Grosso, o Sr. Marques da Silva forneceu, por sua vez, uma imagem ainda mais próxima do projeto político em questão, através do relato oral concedido ao professor Anjos Filho, situando o instante da criação da viola-de-cocho em um passado incerto, às margens do Rio Cuiabá.

Segundo o conhecimento popular, a origem da viola-de-cocho em Mato Grosso se deu quando um artesão, fabricante de canoas, colheres de pau, gamelas e outros utensílios de madeira, residente na beira do Rio Cuiabá, certo dia viu uma embarcação atracar próximo à sua casa. Desta embarcação desceu um homem identificado a princípio como sendo de origem paraguaia. Este homem trazia consigo um curioso instrumento de cordas que principiou a bater assim que pisou terra firme. 0 artesão, meio que por encanto, se apaixonou pelo som daquele instrumento que até então jamais sonhara existir. Conta a história popular que o referido homem viera até a Vila Real do Senhor Bom Jesus de Cuiabá à procura de serviço. Ele era um artista. Como não encontrou na Vila o que precisava, partiu levando consigo o seu instrumento. 0 artesão, vendo-se na possibilidade de não mais tornar a ver e ouvir aquele objeto que gerava som e que lhe causou um sentimento de primeiridade, partiu em busca de uma solução através de seus índices locais. Constatou que por perto de sua morada havia uma certa madeira macia e leve com a qual muitas vezes construíra cochos para dar de comer a animais. Num gesto de profunda criação, após consultar os índices referenciais a sua volta, construiu com ferramentas rústicas um cocho de madeira macia com o formato semelhante ao ícone anteriormente visto e memorizado. Deu então a este cocho macio o formato de viola (também parecida com o formato de uma cabaça ou porongo cortado em sentido longitudinal, muito comum nessa região). Com uma lâmina da raiz da figueira confeccionou um tampo fino que fixou sobre o cocho recém-construído com uma cola feita a partir da poca do peixe, macerada e cozida juntamente com uma folha de bananeira. Transformou, assim, o seu cocho primitivo em uma perfeita caixa de ressonância, faltando-lhe apenas as cordas para que pudesse vibrar... Em Mato Grosso já existia o costume de se fabricarem linhas para pescaria com a fibra de um coqueiro denominado tucum. Portanto, sendo um referencial já conhecido

\footnotetext{
${ }^{49}$ Ver Capítulo I, p. 45-6 desta tese.

50 ROQUETTE-PINTO, Edgar. Rondônia. Rio de Janeiro: Imprensa Nacional, 1919, p. 344. Ver também o Capítulo II, p. 99 desta tese.
} 
pelos índios da região, o artesão logo se utilizou da fibra para concretizar seu sonho de terminar, por fim, seu instrumento musical. Uma vez pronto o seu instrumento, a partir dos índices assimilados da cultura local, o artesão partiu com seu invento rumo à Vila Real. Não houve quem não perguntasse ao moço, pelo caminho, que instrumento era aquele semelhante a uma viola. E o artesão em sua simplicidade logo foi dizendo: "Viola... Mas, viola? Que viola? Viola d'um cotcho?.." 51

Em narrativas como a do Sr. Luís Marques, a construção inventiva a cargo tanto do entrevistado quanto do entrevistador nos faz atentar para a importância de se considerar não somente os discursos formulados, mas a reformulação dos mesmos a partir das variadas leituras de seus personagens. Roger Chartier, ao investigar os processos de apropriação e resignificação em suas proposições para uma história do livro, busca traçar também uma história da leitura ao considerar de igual importância os instrumentos de apropriação de um determinado discurso por parte dos seus destinatários. ${ }^{52}$ Análogo entendimento pode ser perseguido observando-se a disputa pela posse exclusiva de um determinado símbolo de referência, da ideia de marca característica de um lugar em detrimento de uma noção de origem mais complexa e abrangente. A narrativa de um possível percurso histórico da viola-de-cocho que passa por uma herança europeia agrada menos que a versão da sua gênese à beira do Rio Cuiabá. Tampouco agrada aos defensores locais dividir este espaço com seus vizinhos sul-mato-grossenses que, curiosamente, abarcam a parte maior do território da Planície Pantaneira.

Pois, foi em torno da viola-de-cocho que ocorreu uma das mais acaloradas contendas envolvendo artistas, produtores, jornalistas, políticos e intelectuais (incluindo algumas das proclamadas vozes defensoras da cultura local), que teve como consequências o seu tombamento pela Assembleia Legislativa do Estado e o seu registro no Livro dos Saberes do IPHAN como Patrimônio Cultural de Mato Grosso e do Brasil. Em 1987, o músico e professor Abel dos Santos Anjos Filho, natural de

\footnotetext{
${ }^{51}$ Relato do Sr. Luís Marques Silva concedido ao Professor Abel Santos Anjos Filho em 22/08/1992. In: ANJOS FILHO, Abel Santos. Uma melodia histórica: eco, cocho, cocho-viola, viola-de-cocho. Cuiabá: A. S. Anjos Filho, 2002, p. 67-68.

${ }^{52}$ CHARTIER, Roger. À beira da falésia: a história entre certezas e inquietudes. Porto Alegre: EdUFRGS, 2002, p. 70. Ver também: CHARTIER, Roger. Do palco à página: publicar teatro e ler romances na época moderna - séculos XVII - XVIII. Rio de Janeiro: Casa da Palavra, 2002.
} 
Uberaba - MG, mudou-se para Cuiabá, tendo logo se encantado pelos sons da viola dos ribeirinhos. Sendo o violão clássico uma de suas múltiplas formações, o maestro mineiro aplicou com muita propriedade seus conhecimentos técnicos sobre este instrumento no estudo da viola-de-cocho. Ampliou as suas possibilidades harmônicas e melódicas, adicionando mais dois pontos (trastes) no braço e utilizando mais de um tipo de afinação. Tais mudanças possibilitaram ao artista explorar novos repertórios, aperfeiçoando uma técnica que até então não havia sido utilizada para aquele instrumento. Três anos mais tarde ele já estava à frente de projetos ligados à tradição musical da região, a convite do movimento Muxirum Cuiabano, que o levou a ser agraciado com o título de cidadão cuiabano ${ }^{53}$. Em 1996, lançou seu primeiro CD como instrumentista, arranjador e compositor da viola-de-cocho, o que fez seu trabalho repercutir nacionalmente e despertar o interesse de instrumentistas de várias partes do país. Como os compromissos de artista virtuoso da viola se multiplicaram, Abel decidiu abrir uma empresa com o nome "Viola de Cocho Produções Artísticas Ltda". 0 registro feito no Instituto Nacional de Propriedade Industrial (INPI) dava, segundo Heloisa Ariano, exclusividade no uso do nome do instrumento ao artista empresário "para os itens relacionados à prestação de serviços de diversão e auxiliares, organização de feiras, congressos e semelhantes e sociais sem finalidade lucrativa" 54 . O que aconteceu em seguida foi o cantor de Rasqueado Roberto Lucialdo saber que não poderia manter o mesmo nome de sua banda chamada "Viola de Cocho", formada havia mais de dois anos. Notícia que se espalhou e fez com que Abel fosse execrado em seu meio, acusado não apenas de patentear um símbolo da cultura local (impedindo, com isso, que qualquer outro artista pudesse fazer uso do instrumento ou do seu nome), mas também de descaracterizar a viola-de-cocho por não tocá-la à maneira dos ribeirinhos (Anjos Filho executava prelúdios de Bach e o Hino Nacional Brasileiro na viola-de-cocho e isso significava, no juízo de seus adversários, uma afronta à expressão autêntica dos cururueiros). Daí, para o caso se tornar um escândalo em todo o Estado, com os jornais impressos e a televisão repercutindo as acusações, foi um passo. A oposição a Abel mobilizada no meio musical pelas cantoras Vera Baggetti e Zuleica Arruda promoveu passeatas, abaixo-assinados e uma ação

\footnotetext{
${ }^{53}$ ARIANO, Heloisa Afonso. Vozes da Cuiabania: identidade e globalização no rasqueado cuiabano. Dissertação de mestrado em Antropologia. Curitiba: UFPR, 2002, p. 79.

${ }^{54}$ Ibidem, p. 82.
} 
judicial buscando impedir o registro no INPI. Também levou o então deputado Wilson Santos a encaminhar um projeto legislativo de tombamento da viola-de-cocho como patrimônio histórico do Estado. A polêmica se estendeu a vários segmentos da sociedade cuiabana, conforme episódio relatado à imprensa pelo próprio maestro:

\begin{abstract}
Abel relatou um fato grotesco que aconteceu naquele período quando foi abordado por um senhor na Feira do Porto, que o afrontou, perguntando agressivamente: "O Sr. é aquele que nos roubou, não é?" Ao tentar se explicar o homem passou a berrar com ele chamando-o de ladrão da cultura alheia, de safado! Passou a gritar com ele, enquanto chamava outros amigos feirantes, e deram uma carreira atrás dele, que se lançou desesperadamente para dentro de sua Caravan (que conserva até hoje) em busca de proteção, de um abrigo, "pelo amor de Deus!", fechando o carro com muita pressa, ligando-o rapidamente, enquanto os chutes batiam fortemente em sua porta, amassando-a, e ele se mandava, fritando os pneus ${ }^{55}$.
\end{abstract}

Algumas vozes saíram em defesa de Anjos Filho. Entre elas, a da professora especialista em semiologia da cultura Valéria Moreira que via na fala dos "culturetes" (apelido dado aos adversários de Abel) o radicalismo provinciano daqueles que não entendiam que "cultura é um processo social dinâmico e interativo" 56. Em artigo de junho de 1996, no jornal A Gazeta de Cuiabá, o jornalista João da Silva Negrão considerava positivo o debate em torno da preservação do patrimônio históricocultural do Estado, mas era inaceitável o massacre imposto à figura do professor Abel, colocando-o como "usurpador, sequestrador e charlatão", numa "clara demonstração de ignorância (nos dois sentidos da palavra) e de mediocridade" 57. Negrão ainda argumentava que, mesmo experimentando novas possibilidades técnicas e diferentes estilos musicais em suas performances, a postura de Abel era de respeito à tradição, pois mantinha parcerias de trabalho com os cururueiros e artesãos amigos e baseava suas pesquisas na longa história da viola-de- $\operatorname{cocho}^{58}$. A artista plástica Marta Catunda

\footnotetext{
${ }^{55}$ FERREIRA, Eduardo. A peleja da viola-de-cocho com o anjo mineiro. Weblog publicado em 20/10/2006. Disponível em:< http://www.overmundo.com.br/overblog/peleja-da-viola-de-cocho-com-o-anjo-mineiro $>$ Acesso em: 19/03/2015.

${ }^{56}$ MOREIRA, Valéria Pereira. Apud ARIANO, Op. cit., p. 85.

${ }^{57}$ NEGRÃO, João da Silva. Apud ARIANO, Op. cit., p. 87.

${ }^{58}$ Idem.
} 
também lamentava a opção de um dos lados por negar a diversidade que deveria existir na arte:

É desanimador que os combatentes da mesma trincheira, com os mesmos objetivos, se desgastem em disputas domésticas por espaço de manifestação e expressão em uma sociedade que absorveria e valorizaria as duas alas de contendores: os que abraçaram a perspectiva da cultura erudita e da cultura popular. Será que a sobrevivência de uma das perspectivas supõe a aniquilação da outra?59

Anjos Filho teve sua solicitação de registro no INPI indeferida em 26 de maio de 1998, com a justificativa de que a Lei de Propriedade Industrial impede a apropriação de nome de uso comum. 0 músico, porém, recorreu da decisão e em dezembro do mesmo ano sua empresa ganhou o direito de usar o nome como marca ${ }^{60}$. Continuou a divulgar seu trabalho com a viola-de-cocho através de seus CDs, shows e concertos, atuando como produtor, instrumentista, cantor, compositor, arranjador e professor do Departamento de Artes da UFMT. Passaram-se os anos e as polêmicas se dissiparam. Tanto, que a ideia da criação de uma orquestra em Mato Grosso com um naipe permanente de violas-de-cocho (e mais um instrumental de percussão que incluía o mocho, o ganzá e a bruaca), encampada em 2004, pelo então Secretário de Estado da Cultura João Carlos Vicente Ferreira, foi pronta e amplamente aceita pelo público cuiabano61.

A guerra travada em nome da viola-de-cocho pela Cuiabania e Anjos Filho exemplifica o peso que essas verdadeiras "lutas de representações" têm em determinados contextos de afirmação de identidades. Tão ou mais decisivas, segundo Chartier, que as disputas econômicas ou políticas propriamente ditas, quando "um grupo impõe, ou tenta impor, a sua concepção do mundo social, os valores que são os seus, e o seu domínio" 62.

\footnotetext{
${ }^{59}$ CATUNDA, Marta Bastos. Apud ARIANO, Op. cit., p. 89-90.

${ }^{60}$ VIANNA, Letícia. Dossiê 8: modo de fazer viola-de-cocho. Brasília: Iphan, 2009, p. 73.

${ }^{61}$ FERREIRA, João Carlos Vicente. A propósito da orquestra de Mato Grosso. Olhar Direto - Cuiabá, MT. publicado em 27/04/2010. Acesso em <http://www.olhardireto.com.br/artigos/exibir.asp?id=1620 > Acesso em: 21/05/2013.

${ }^{62}$ CHARTIER, Roger. A história cultural: entre práticas e representações. Lisboa: Difel, 2002, p. 17.
} 


\section{POR VARIADOS ESTILOS}

Mário de Andrade enxergava em várias expressões musicais populares do Brasil a mesma fórmula das suítes europeias consagradas no Barroco (que reunia em uma obra instrumental uma série de movimentos na mesma tonalidade, sendo todos eles, ou a sua maioria, formas ou estilos de danças). Para o musicólogo brasileiro, os Fandangos do sul paulista, os Cateretês do centro brasileiro e os Cabocolinhos do nordeste eram "formas populares primárias da suíte" 63. Outros folguedos dramáticos de rua também se enquadrariam no mesmo princípio formal, como no caso das Cheganças, dos Reisados e Congadas dos negros, assim como as cerimônias coreográfico-religiosas de Santa Cruz e São Gonçalo que costumam terminar com um Cururu64. Do mesmo modo como há nas suítes barrocas uma "ordem clássica" (allemande, courante, sarabande e gigue), Andrade propunha aos compositores eruditos brasileiros um formato de suíte com os seguintes andamentos:

I. Ponteio (prelúdio em qualquer métrica ou movimento);

II. Cateretê (binário rápido);

III. Coco (binário lento, num substituto da sarabanda);

IV. Moda ou Modinha (em ternário ou quaternário, num substituto da Aria antiga);

V. Cururu (sem andamento predeterminado);

VI. Dobrado (ou Samba, ou Maxixe, em um binário rápido ou imponente final).

Como alternativa ao movimento Cururu (para a utilização de um motivo ameríndio), o musicólogo paulista ainda sugeria o nome de uma das danças africanas (para a utilização de um motivo afro-brasileiro, sem andamento predeterminado) 65 .

Foram vários os compositores eruditos que adotaram a fórmula da Suíte de Danças Brasileiras (incluindo o maior deles, Heitor Villa-Lobos, com suas nove Bachianas Brasileiras, escritas entre 1930 e 1945), mas foram poucos os que incluíram o Cururu como um dos seus movimentos. Eduardo Escalante cita dois

\footnotetext{
${ }^{63}$ ANDRADE, Mário de. Dicionário Musical Brasileiro. Belo Horizonte: Itatiaia, 1999, p. 490.

${ }^{64}$ Enciclopédia da música brasileira. São Paulo: Art Editora, 1977, p. 221-3.

${ }^{65}$ ANDRADE, Mário de. Ensaio sobre a música brasileira. Belo Horizonte: Itatiaia, 1972, p. 68.
} 
exemplos apenas: a Brasiliana no 3 para piano solo de Osvaldo Lacerda, composta em 1967, (com os movimentos Cururu, Rancheira, Acalanto, Quadrilha) e a Suíte no 1 para piano solo do próprio Escalante, escrita em 1968 (com os movimentos Cantiga de Roda, Acalanto, Cururu, Tanguinho, Embolada) ${ }^{66}$. Nos dois casos, a referência ao Cururu paulista está submetida à estética do Nacionalismo na música brasileira de concerto pregada pelo seu mentor Mário de Andrade.

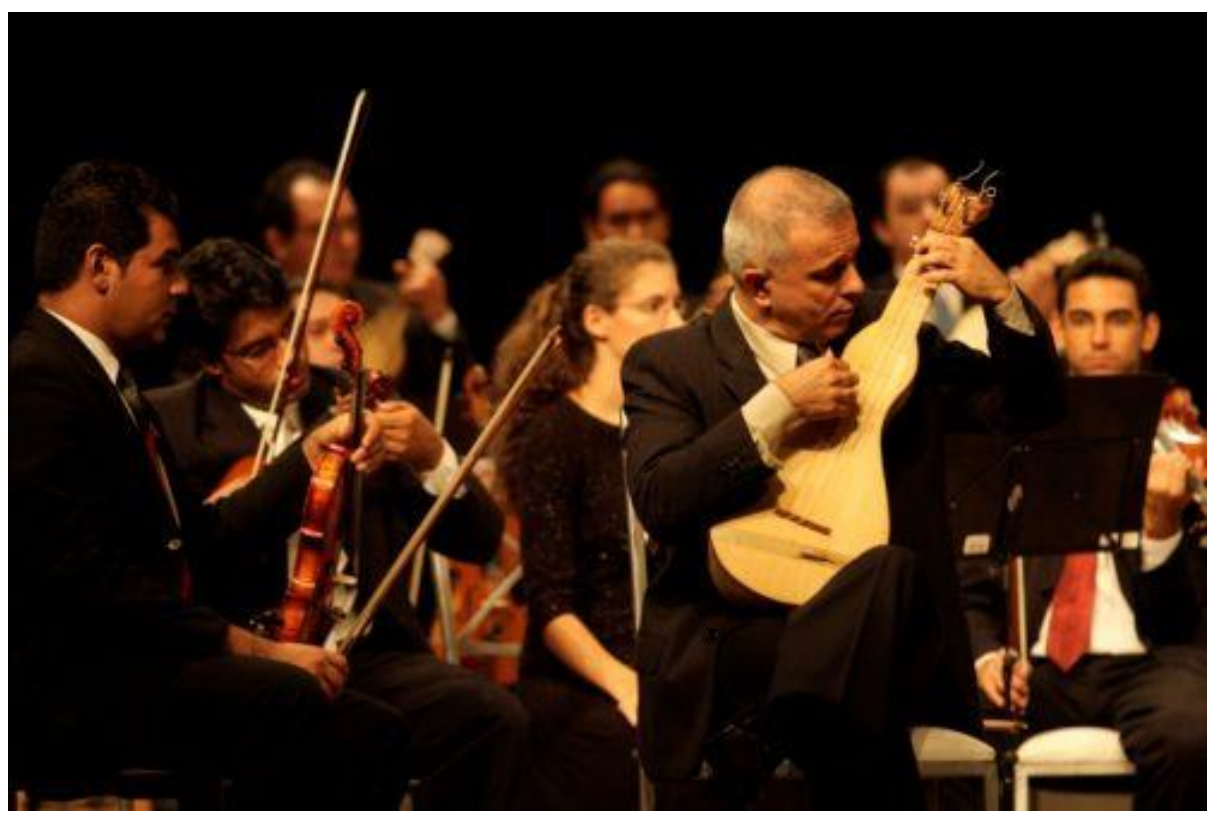

Figura 5: Roberto Corrêa e a Orquestra de Mato Grosso Fonte: OMT, 2009

Em outro exemplo, este mais recente, o compositor paulista Danilo Guanais compôs uma suíte para orquestra de cordas, vozes masculinas e percussão intitulada "A Festa da Santidade", encomendada pela Orquestra de Mato Grosso para ser executada nas comemorações dos 295 anos da fundação de Cuiabá, em 2014. Segundo o autor, a obra foi concebida em seis movimentos (I - Rainhado; II - Preparação do altar - recitativo; III - Saudação do altar; IV - Subida do mastro; V - Louvação; VI Desafio - Cururu) fazendo "uso livre dos elementos conhecidos do folguedo, principalmente os ritmos básicos e os temas cantados por alguns dos cururueiros mais conhecidos" 67. O referencial estético desta peça é também o Nacionalismo

\footnotetext{
${ }^{66}$ ESCALANTE, Eduardo Alberto. A música no Cururu do Médio Tietê Paulista. Dissertação de Mestrado. São Paulo: ECA/USP, 1986, p. 130. Cf. LACERDA, Osvaldo. Brasiliana n. 3 para piano solo. São Paulo: Irmãos Vitale, 1967.

${ }^{67}$ ORQUESTRA DO ESTADO DE MATO GROSSO. Temporada 2013. Disponível em: <http://www.orquestra.mt.gov.br/noticias.php?not id=30 > Acesso em: 21/04/2015.
} 
Musical Brasileiro, podendo ser notado nela certo sabor das obras corais do mestre Villa-Lobos, pelo emprego da melodia coral em uníssono e sequências harmônicas descendentes (faixa 10 do CD em anexo). Até onde sabemos, esta é a única peça de compositor erudito que utilizou o termo cururu em um de seus movimentos, em referência direta à versão mato-grossense do folguedo. São mais comuns, no entanto, as aproximações deste universo da música erudita com as expressões da cultura popular local, através da utilização dos seus instrumentos típicos, em especial a violade-cocho.

Em 1994, o compositor carioca Roberto Victorio transferiu-se para Cuiabá, ocasião em que assumiu o posto de regente e diretor artístico da Orquestra Sinfônica da UFMT para se dedicar exclusivamente ao repertório musical do século XX. No mesmo ano, concebeu a obra Planalto Central em Três Poemas para voz e pequena orquestra, juntando à formação convencional do agrupamento sinfônico instrumentos normalmente empregados na música folclórica e étnica da região (ganzás, chocalhos indígenas e pau de chuva, além de três violas-de-cocho e um berrante). Victorio recorreu a poemas de três dos mais ilustres escritores nativos Wlademir Dias Pino, Silva Freire e Manoel de Barros - para estruturar sua música em três movimentos distintos, um para cada poema. Através do emprego dos textos nas formas cantada e recitada e do uso de polirritmias e fórmulas de compasso alternadas, o compositor construiu ambiências sonoras inusitadas, dando ênfase a elementos extramusicais como a literatura e a numerologia. Com este trabalho, Roberto Victorio foi pioneiro na inserção de elementos locais em uma obra sintonizada com a estética das vanguardas do século $\mathrm{XX}$, trabalhando com uma linguagem musical atonal, utilizando algumas técnicas expandidas dos instrumentos e contando com a participação dos intérpretes na criação da peça, entre outros procedimentos comumente usados na música erudita contemporânea ${ }^{68}$.

Outra obra musical a ser destacada neste contexto é a Sinfonia Pantaneira de Abel dos Santos Anjo Filho. Trata-se de um concerto para instrumento solista, a violade-cocho, com acompanhamento de orquestra de cordas, em quatro andamentos: IPantanal quem fecit Dominus (O pantanal que o senhor fez); II- Finis vesperis (Fim de

\footnotetext{
${ }^{68}$ SANTOS FILHO, Francisco Lopes dos. Planalto Central: marco da música contemporânea em Mato Grosso. Dissertação de mestrado. Cuiabá: UFMT/IL, 2011, passim.
} 
tarde); III- Sonoribus et coloribus plenus Pantanal (Pantanal cheio de sons e cores); IVExultantia chorda (Corda/coração exultante). A peça foi estreada em 2004, tendo como solista o compositor, acompanhado pelas cordas da Orquestra de Câmara de Mato Grosso ${ }^{69}$. Além do mérito de colocar a viola-de-cocho no patamar de instrumento solista, explorando inclusive as suas possibilidades polifônicas, o grande atrativo da criação de Anjos Filho é o seu lirismo, em vários momentos lembrando o Romantismo tardio do Concerto de Aranjuez, do compositor espanhol Joaquim Rodrigo. Em outros momentos, o melodismo derramado das serestas antigas se mistura à tessitura e ao timbre delicado da viola, fazendo jus ao título dado ao instrumento por Julieta de Andrade de alaúde brasileiro (faixa 11 do CD em anexo) ${ }^{70}$.

Na música mais diretamente ligada ao mercado fonográfico e aos veículos de comunicação de massa, encontramos alguns exemplos de apropriação de elementos relacionados ao Cururu, ao Siriri e à viola-de-cocho, que merecem ser também destacados. Com mais de 20 anos na cena do rock em Cuiabá, a Banda Strauss ganhou certa notoriedade nacional fazendo referência em suas produções à cultura popular da região. Ficou conhecida por fundir rock com Rasqueado. Em um de seus vídeos clips mais assistidos, os rapazes interpretam a canção tradicional "A Lua", colocando em cena, na beira do Rio Cuiabá, cururueiros com seus instrumentos ${ }^{71}$. Se há ressalvas a serem feitas nesta abordagem regionalista da banda Strauss, a primeira é a de que nada se ouvia da viola-de-cocho, do mocho ou dos ganzás, em meio aos sons da guitarra, do baixo e da bateria. Ainda assim, outros roqueiros buscaram contornar o pequeno volume de som destes instrumentos através de experimentos como o do guitarrista Caio Espínola Schlösser, da dupla "Billy Brown e o Incrível Mago de Bigodes". Sua banda foi criada em 2014, com a proposta de interpretar rock'n'roll e blues com acento local. 0 intuito era, mais uma vez, o de dar novo significado à violade-cocho. Porém, insatisfeito com as limitações técnicas do instrumento ribeirinho, de características mais percussivas que harmônicas ou melódicas, Schlösser efetuou algumas mudanças no exemplar por ele adquirido em uma das lojas de artesanato da

\footnotetext{
${ }^{69}$ SECRETARIA DE ESTADO DA CULTURA. Orquestra de câmara do Estado estreia "Sinfonia Pantaneira". Cuiabá, 2004. Disponível em <http://www3.cultura.mt.gov.br/TNX/imprime.php?cid=751\&sid=54 > Acesso em 24/03/2014.

${ }^{70}$ ANDRADE, Julieta. Cocho mato-grossense: um alaúde brasileiro. São Paulo: Livramento, 1981.

${ }^{71}$ MACHADO, Marcela. A noite é do rock! Portal RDM online. Disponível em <http://www.rdmonline.com.br/TNX/imprime.php?cid=4147\&sid=53 > Acesso em: 22/04/2015.
} 
capital; entre elas, a instalação de cordas metálicas, captador e potenciômetro elétricos e tarraxas de aço no lugar das cravelhas de madeira. Surgiu assim a "guitarra-de-cocho" 72.

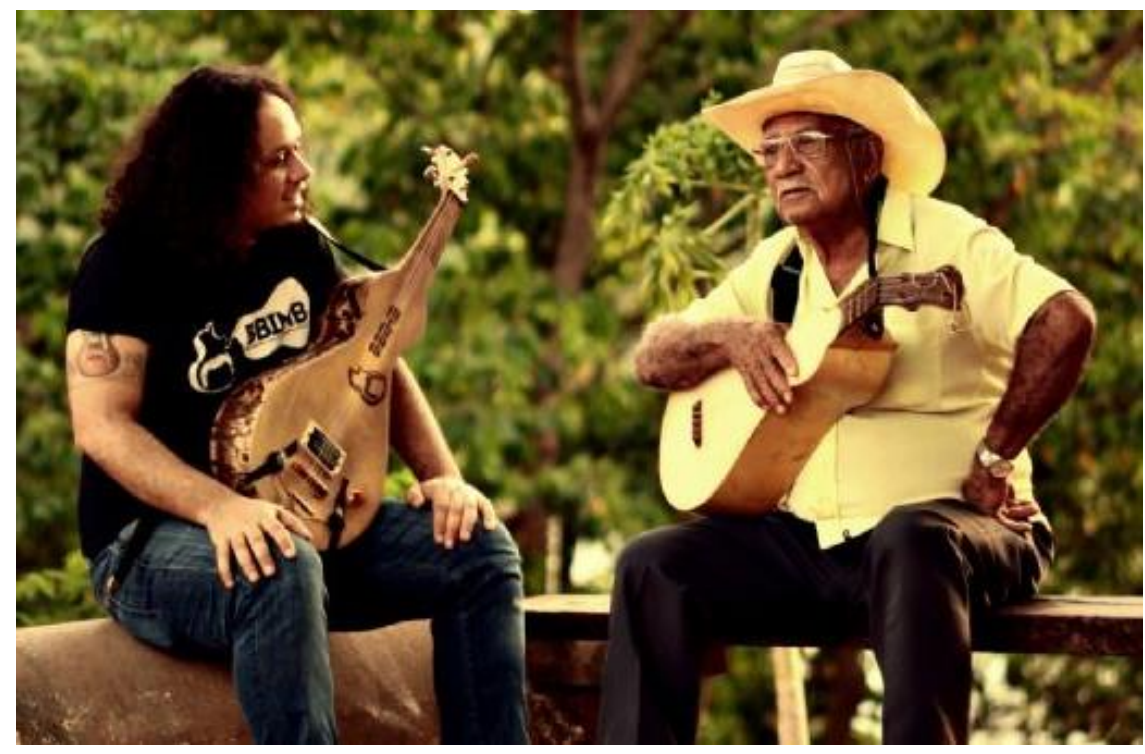

Figura 6: Caio Espinola Schlösser e Seu Bagé encontro da guitarra com a viola-de-cocho Fonte: Medeiros, 2015

O lado interessante desta adaptação foi que as madeiras macias da caixa de ressonância fizeram ressaltar os sons graves do instrumento, preenchendo simultaneamente a gama sonora da guitarra e do baixo elétricos. Outro aspecto revelado pelo instrumento híbrido de Schlösser foi a sonoridade parecida com a das guitarras da country music norte-americana, evidenciada no uso da técnica slide guitar, que faz um cilindro metálico (bottleneck), que envolve o dedo anelar esquerdo, deslizar pelas cordas do instrumento, produzindo longos portamentos. A bem recebida novidade da "guitarra-de-cocho" parece ter demonstrado que os tempos de intolerância vividos por Abel dos Anjos ficaram no passado (figura 6).

Outra importante aproximação do universo das representações populares do centro-sul brasileiro com o mercado da música, a primeira e talvez a de maior alcance midiático, ocorre entre o Cururu e a música sertaneja. Referimo-nos inicialmente ao

\footnotetext{
72 MEDEIROS, Stéfanie. Lançamento de documentário que conta a história da guitarra-de-cocho será neste sábado. Portal Olhar Direto. Publicado em 14/04/2015. Disponível em:

< http://www.olhardireto.com.br/conceito/noticias/exibir.asp?noticia=Lancamento de documentario que conta_a historia da guitarra-de-cocho sera neste_sabado\&id=7365 > Acesso em: 02/05/2015.
} 
Cururu paulista, com as primeiras gravações em disco $78 \mathrm{rpm}$ da "Turma Caipira Cornélio Pires", realizadas a partir de 1929. Pires decidiu por conta própria produzir e comercializar em disco as anedotas por ele contadas e a música caipira que vinha divulgando em apresentações ao vivo, desde 1910, já que as gravadoras instaladas no país não quiseram investir na ideia. A iniciativa fez, no entanto, com que a gravadora Victor revisse a sua decisão e procurasse o cantor Olegário José de Godoy, o Sorocabinha, para formar, no mesmo ano de 1929, a "Turma Caipira Victor", reunindo nomes como Sebastião Ortiz de Camargo, Antônio Estevan, Sebastião Roque, Manoel Rodrigues Lourenço "Mandí”, e as filhas de Sorocabinha, Avelina, Durvalina e Maria Imaculada, para lançá-los no mercado de disco nacional. Estes foram os cinco primeiros discos do gênero lançados pela Victor:

I - VICTOR - № 33234 (12/1929)

A - Samba - Dança Típica Paulista - Olegário José de Godoy

B - Paulista e Gaúcho - Desafio

II - VICTOR - № 33235 (12/1929)

A - Cateretê - Dança Típica Paulista - Olegário e Bastiãozinho

B - Olegário e Avelina - Desafio - Olegário e Filha

III - VICTOR - № 33236 (12/1929)

A - Cururu - Dança Típica Paulista - Manoel Rodrigues Lourenço "Mandi"

B - Casamentto da Onça - Moda de Viola - Mandi

IV - VICTOR - № 33237 (12/1929)

A - Adão e Eva - Moda de Viola - Sorocabinha

B - Que Moça Bonita - Mandí

V - VICTOR - № 33238 (12/1929)

A - Caboclo Feliz - Moda de Viola - Sorocabinha

B - Caipira Murtado - Moda de Viola - Mandí 


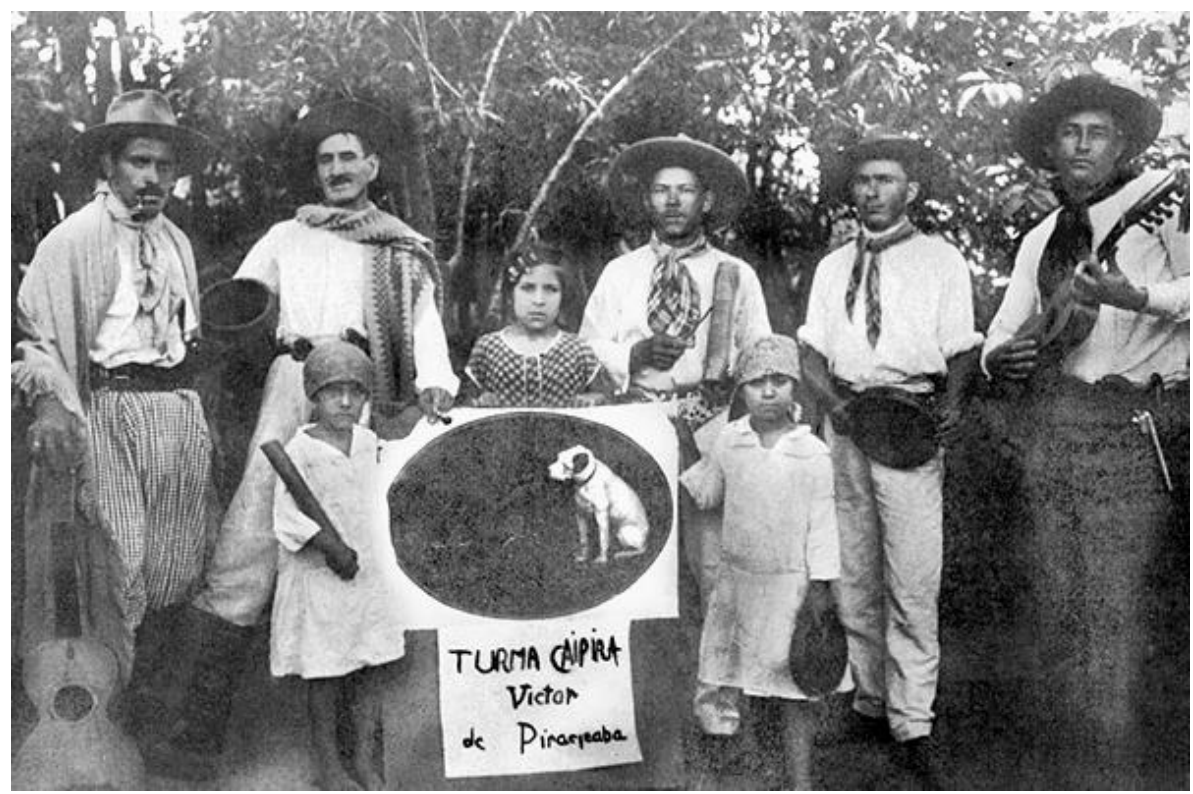

Figura 7: Turma Caipira Victor

Fonte: Peripato, 2008

Dentre os lançamentos de 1929 da RCA Victor, estava um Cururu cantado por Manoel Rodrigues Lourenço, o "Mandí”, um dos primeiros registros discográficos da música caipira paulista73. Não tivemos acesso a esta gravação, apenas a de outro Cururu também cantado por Mandí, em parceria com Sorocabinha, que foi gravado em 1936 pelo selo Odeon (faixa 12 do CD em anexo) ${ }^{74}$. Nesta toada, é evidente a mudança ocorrida em função da sua adaptação ao formato do disco, com a duração de pouco mais de dois minutos, mantendo, porém, a sua estruturação antiga, em apenas uma frase curta e repetitiva, com a melodia formada de figuras simples de colcheias para permitir o improviso poético dos cururueiros. 0 exemplo selecionado trata, de um modo ao mesmo tempo pueril e cheio de reflexão, sobre a existência de várias crenças a respeito da vida do espirito após a morte física:

\section{Tem mistério nesse mundo \\ que é difícil de explicar \\ Dispois que a gente morre, meu Deus do céu, o que será?}

\footnotetext{
${ }^{73}$ PERIPATO, Sandra Cristina. Turma Caipira Victor. São Paulo: Portal Recanto Caipira, 2008. Disponível em: <http://www.recantocaipira.com.br/turma caipira victor.html> Acesso em: 02/05/2015.

${ }^{74}$ MANDI e SOROCABINHA. Cururu. Rio de Janeiro: Odeon. Fonograma cod. 11368-A, 1936. Disponível em: <https://www.youtube.com/watch?v=yCZOpWj82OM > Acesso em: 02/05/2015.
} 
O corpo fica na terra,

alma sobe pelo ar

O Miguel tá esperando

com a balança pra pesar

Se a gente não tem pecado,

vai no céu para gozar

Mas se foi um pecador,

vai no inferno pra penar

[trecho inaudível]

Lembrando dessas coisa,

meu corpo pega a arrepiar

Tem home que é espírita,

com outro modo de pensar

Quem morre é só o corpo,

alma torna a voltar,

arranja outro corpo

pra podê se reencarnar

Deitado nesse mundo,

aqui mesmo tem que pagar

Conforme os pecado,

se reencarna num animar

Tem que padecer

até se purificar

Dispois, pode ir pro céu

aí, com os justo vai morar

E cria um par de asa,

e com os anjinho vai passear

E otros, do que eu disse, 
nada quer acreditar

Não acredita em Deus do céu,

ai, nem dos Santo do artar

Num tem céu, num tem inferno

pra ele tudo é naturar

Não tem Adão, nem Eva,

dos macaco formou geral

Com tantas opinião,

não tem no que acreditar

Se tiver medo do inferno,

o melhor é não pecar,

porque com o "coisa ruim"

é bem difícil acostumar

Eu quero ir pro céu

porque eu gosto de avoar
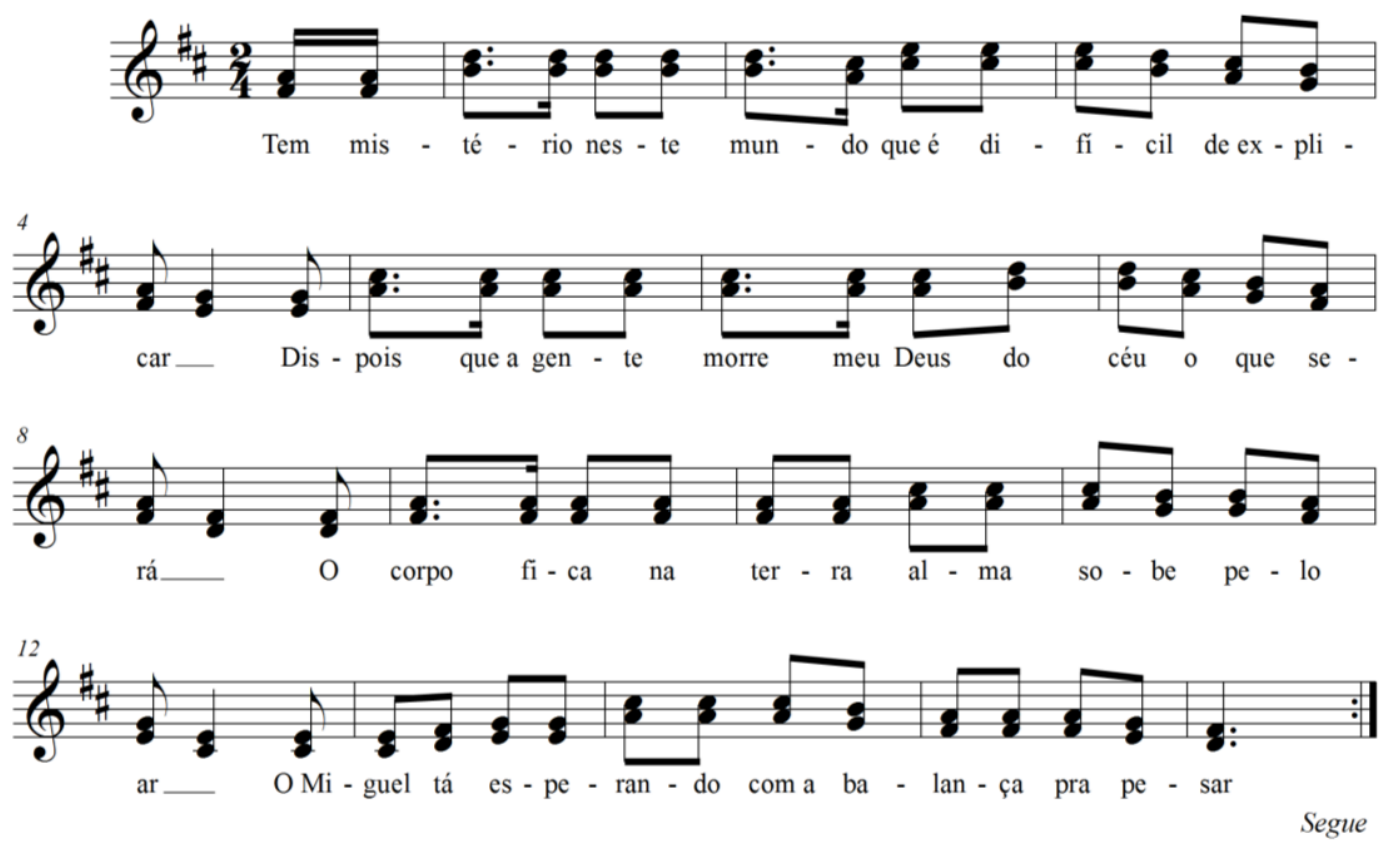

Exemplo 3: Cururu na indústria fonográfica

(Mandi e Sorocabinha)

Fonte: Odeon, 1936. 
Neste Cururu gravado por Mandí e Sorocabinha, o acompanhamento rítmico dos instrumentos aparece na fórmula $\stackrel{\risingdotseq}{\risingdotseq !}$ aproveitada das modalidades tradicionais do Cururu paulista ${ }^{75}$. A mesma célula rítmica presente em exemplos posteriores do gênero cururu-canção, como as composições de Luizinho e Teddy Vieira (Menino da Porteira) e Lourival dos Santos, Piraci e Tião Carreiro (Rio de Lágrimas). A respeito dessas adaptações, José de Souza Martins explica que o Cururu dos discos em 78 rpm apresentou-se como "uma modalidade de música sertaneja totalmente oposta ao Cururu de origem", sem o seu caráter religioso e "sem o desafio secularizado que hoje o caracteriza" 76. Eduardo Escalante também destaca o testemunho de Mandí a respeito das interferências das gravadoras,

[que] solicitavam dos intérpretes apressarem os andamentos e encurtarem as músicas para poderem caber nas faixas limitadas dos discos 78 RPM. Isto reduziu a possibilidade da gravação de Cururus inteiros, desinteressou as gravadoras, impediu que grandes cururueiros como João David, Agostinho Aguiar ou Sebastião Roque deixassem o testemunho de sua arte ${ }^{77}$.

Em verdade, estas importantes mudanças principiaram antes mesmo da chegada do Cururu aos discos, quando o gênero teve que se adaptar ao formato das apresentações ao vivo organizadas pelo folclorista Cornélio Pires, nos palcos dos teatros, dos circos, das rádios e em praças públicas do estado de São Paulo78.

Em Mato Grosso, a música sertaneja comercial chega através dos bailes, dos programas de rádio, dos discos e dos shows, tendo já feito, em grande parte, os percursos aqui descritos. Ela vem influenciar, sobretudo, aqueles gêneros mais próximos do domínio cultural urbano e da cultura de massa, como o Rasqueado cuiabano e o lambadão, mas também não deixa de interagir com os cantadores tradicionais da região, conforme pude testemunhar Seu Tuti, cururueiro de Chapada dos Guimarães, cantando acompanhado de sua viola-de-cocho a canção sertaneja

\footnotetext{
75 IKEDA, Alberto. Cururu: resistência e adaptação de uma modalidade musical da cultura tradicional paulista. In: Folias de reis, sambas do povo. São José dos Campos, SP: CECP/FCCR, 2011, p. 43.

${ }^{76}$ MARTINS, José de Souza. Música sertaneja: a dissimulação na linguagem dos humilhados. In: Capitalismo e tradicionalismo. São Paulo: Pioneira, 1975, p. 123.

${ }^{77}$ ESCALANTE, Op. cit, p. 128

78 IKEDA, Op. cit., p. 43
} 
"Casinha na Serra" de Osvaldo Galhardo e Belmiro, ao lado das toadas de Cururu e Siriri que aprendeu desde pequeno ${ }^{79}$.

Do outro lado, são comuns os exemplos em que representantes da música popular de massa regional fazem referência em suas letras aos símbolos locais, cantando as belezas da mulher cuiabana, a natureza, a comida e a cultura popular em geral, como no caso do rasqueado "É bem Mato Grosso" interpretado por Pescuma, Henrique e Claudinho (faixa 13 do CD em anexo) ${ }^{80}$. Homenagens ao território, a seu povo e a seus costumes que são feitas também através da cenografia dos espetáculos musicais do gênero, como no show "Rasqueia Brasil" gravado em DVD pelo mesmo trio em 2007. Nele, a viola figura no palco apenas como um elemento cênico, com um ator/artesão empunhando um facão representando o ribeirinho que confecciona o instrumento, ao lado de outros personagens como o dançarino de siriri, o pescador, a fiadeira e a comadre devota ${ }^{81}$. Referências que o próprio Pescuma justifica em depoimento à imprensa, dizendo ter ciência das limitações acústicas da viola-decocho e que por isso, como músico, "não mexia com ela" 82.

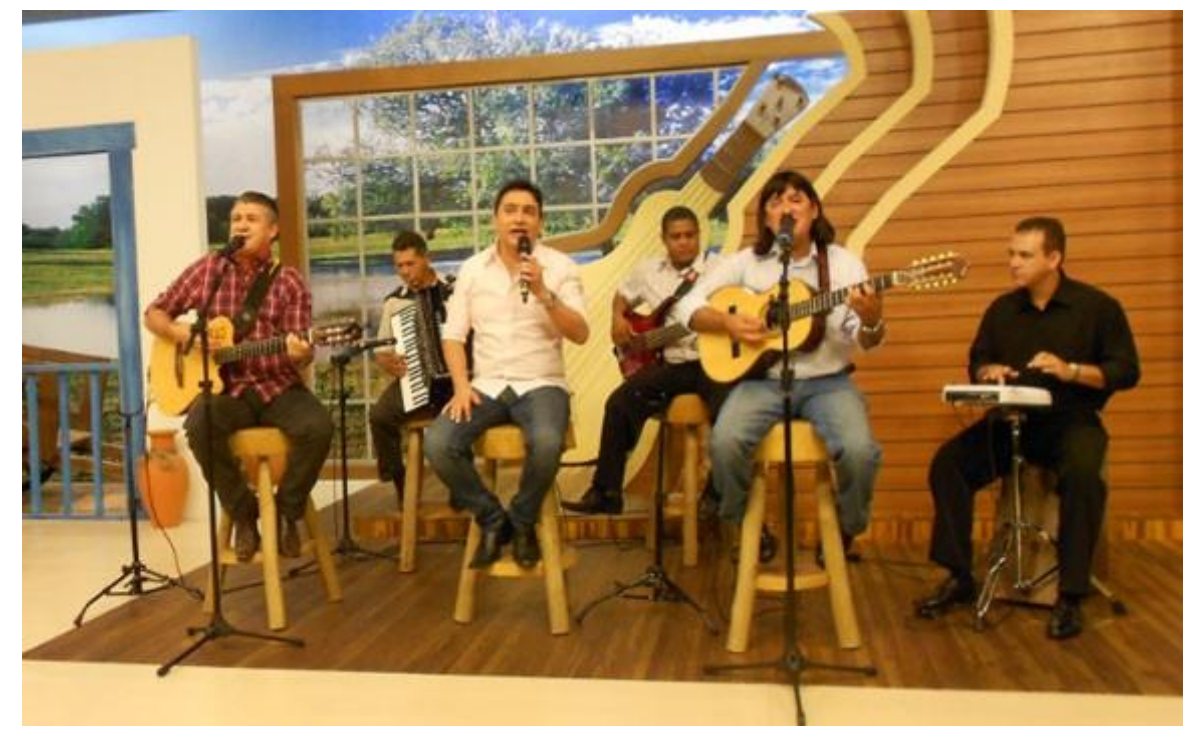

Figura 8: Pescuma, Henrique e Claudinho na tv No cenário ao fundo, um retrato da viola-de-cocho Fonte: TV Centro América, 2014

\footnotetext{
${ }^{79}$ O cururueiro apresentou-se na Mostra de música de Chapada dos Guimarães, em 28 e 29/09/2012. Ensaio da apresentação disponível em: <https://www.youtube.com/watch?v=YNZZCjyry-E > Acesso em: 25/04/2015.

${ }^{80}$ PESCUMA, HENRIQUE e CLAUDINHO. Rasqueia Brasil. São Paulo: MCK. DVD cod. 7899004726787, 2010. Também disponível em: < https://www.youtube.com/watch?v=1N-sPnm89dM> Acesso em: 25/04/2015.

${ }^{81}$ Idem.

${ }^{82}$ ARIANO, Op. cit., p. 91.
} 
Trata-se de um discurso também extraído das intervenções feitas na paisagem urbana de Cuiabá ao longo das três últimas décadas, com esculturas e painéis estampados em muros, praças e canteiros, além dos interiores de restaurantes, hotéis e prédios públicos representando sempre os mesmos temas: bichos dos rios e matas, frutas, gamelas, e pilões, além do ribeirinho e sua viola, aqui destacados. Ao percorrer a cidade por algumas de suas principais avenidas, o transeunte encontrará exemplares do tipo que vão desde a reprodução em grande escala da viola-de-cocho, com cerca de dois metros de altura, exibida na Praça Rachid Jaudy, até a série naturalista pintada nos muros e viadutos da Avenida Miguel Sutil, pelos artistas Adir Sodré e Sebastião Silva (figura 9). Também verá os bonecos do Cururu e do Siriri com seus instrumentos, no trevo de acesso ao bairro Recanto dos Pássaros, pela Avenida das Torres, tendo ao fundo, na parte central do mesmo canteiro, com 15 metros de altura, uma escultura em metal fundido de uma viola estilizada, de autoria do artista plástico Frede Fogaça (figura 10).

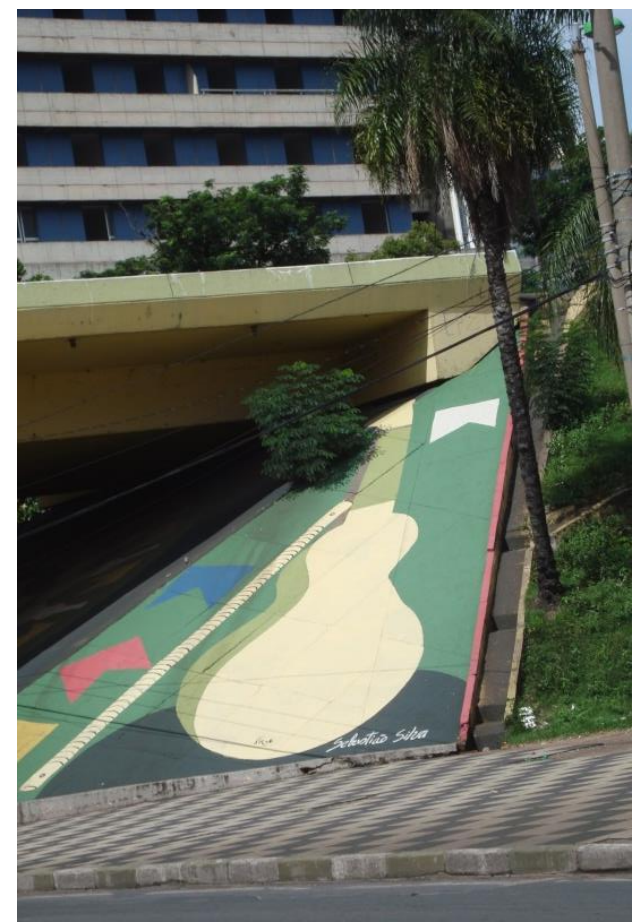

Figura 10: Pintura de Sebastião Silva Av Miguel Sutil, Cuiabá Fonte: o autor

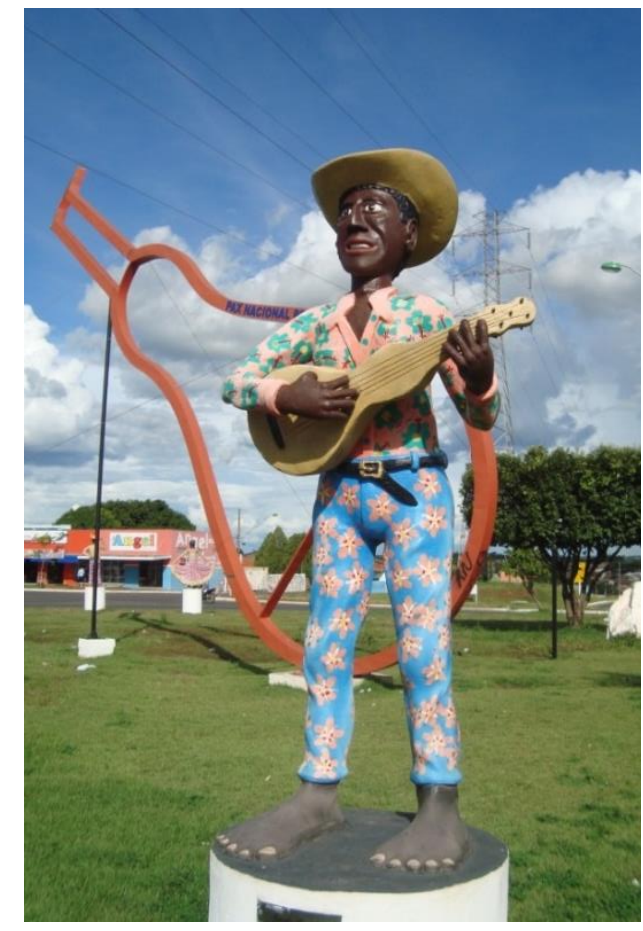

Figura 9: Esculturas de Frede Fogaça Av das Torres, Cuiabá Fonte: o autor 
Esta mensagem visual consagrada através do ideário regionalista gestado nos anos 70 pelos intelectuais e burocratas da universidade e do governo passa a ser projetada em diferentes espaços e equipamentos da cidade, formando um conjunto de símbolos e valores identitários que remetem a um passado idealizado de proximidade com a natureza e a vida rural, dado como parte, desde sempre, da memória histórica e afetiva do lugar e das pessoas. Os artistas a representar esta temática estariam reunindo neste repertório de imagens ou "objetos puros" um conjunto simbólico chamado por Suzana Guimarães de "baú iconográfico" da região ${ }^{83}$. Baú do qual seriam retirados elementos simuladores, segundo Nolasco dos Santos, de uma realidade "edênica" reduzida apenas à "bicharada no cimento [...], que pouco ou nada tem de santuário ecológico do mundo" 84.

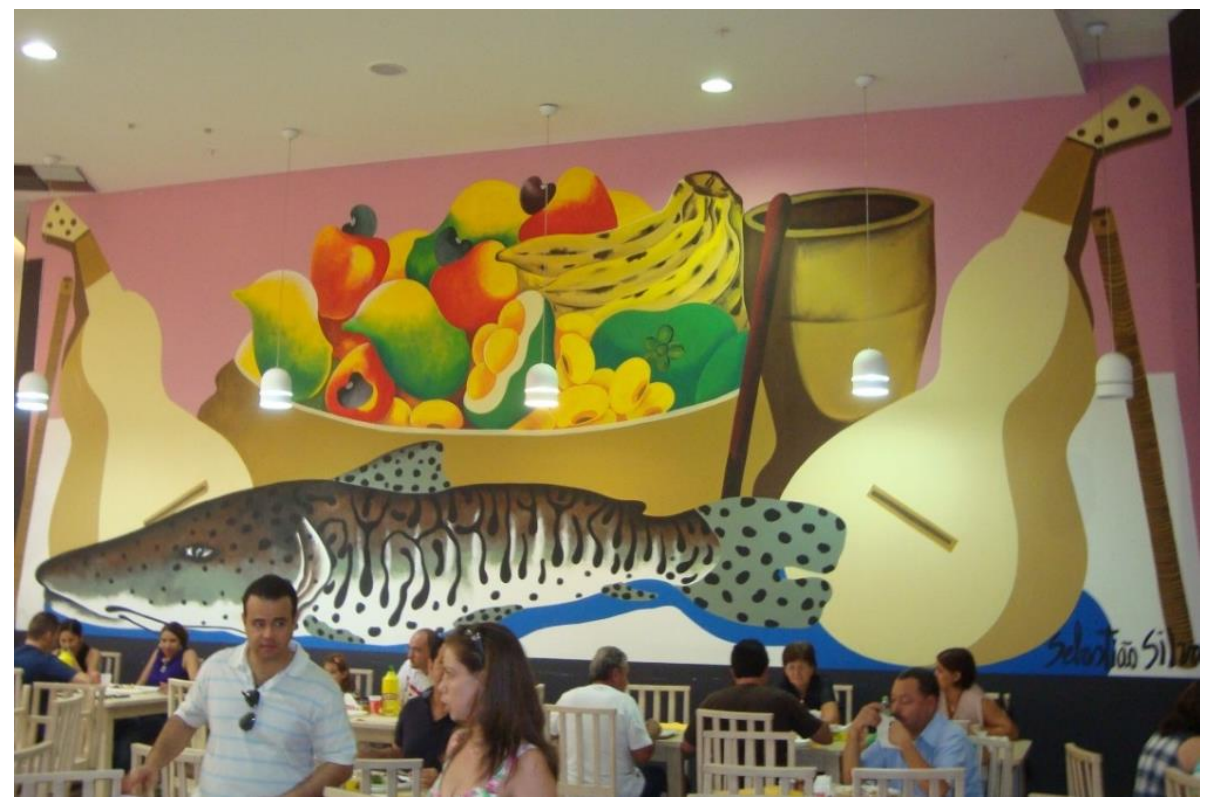

Figura 11: Painel pintado por Sebastião Silva Shopping Pantanal, Cuiabá Fonte: o autor

Diante destas e de outras interposições imagéticas na cidade, em especial da viola-de-cocho nos espaços urbanos abertos, nos palcos de espetáculos ao vivo e programas televisivos - incluindo o seu uso como mercadoria turística e publicitária não seria exagero dizer que hoje em Cuiabá ela é mais vista que ouvida pela sua

\footnotetext{
${ }^{83}$ GUIMARÃES, Op. cit., p. 173.

${ }^{84}$ SANTOS, Paulo Sérgio Nolasco dos. "Representações artísticas e limites espaciais: o regionalismo revisitado" In: RUSSEF, Ivan \& SANTOS, Paulo Sérgio Nolasco dos (org.) Ensaios farpados: arte e cultura no pantanal e no cerrado. Campo Grande: Letra Livre, 2004, p. 56.
} 
população. E o fato de alguns críticos como Suzana Guimarães e Sérgio Nolasco questionarem o sentido artístico de tais obras, os leva a refletir acerca do desafio do criador e o seu público na decisão de como e quando "sair da armadilha" do kitsch.

A arte realista de cunho identitário, comprometida em representar o concreto, em objetivar uma imagem ligada a um tema ou assunto anterior, e levada ao limite de sua capacidade de recusar a cópia de si mesma, menospreza o espaço da fantasia e da invenção, esvazia o sentido da criação, subordinando sua produção pictórica a uma fabricação e comercialização compulsiva e serializada de imagens, facilmente identificadas como sendo as imagens do pintor da onça, do pintor da manga, do pintor do boi, do pintor do peixe, do pintor da flor, da folhagem e da borboleta, do pintor da roça, da pintora repórter de Cuiabá, do pintor da viola-de-cocho, todos eles reduzidos a pintores do baú iconográfico ${ }^{85}$.

${ }^{85}$ GUIMARÃES, Op. cit., p. 167. 


\section{CONSIDERAÇÕES FINAIS}

\section{[...] corria música entre a gentana dançando} mexida no cururú.

Mário de Andrade, Macunaíma, 1928

Em uma função de Cururu ocorrida entre os Guató da Aldeia Figueira, no Pantanal, os índios Timóteo, José e Rosa protagonizaram uma grande algazarra, com gritos e agressões a pauladas, depois de duas noites seguidas de diversão. Para o etnólogo alemão Max Schmidt, que presenciara a cena na região do Amolar, em 1901, a bebedeira de aguardente e as ofensas proferidas nos versos improvisados do Cururu de Timóteo haviam sido os motivos de toda a confusão, algo comum nas rodas de Cururu do século XIX em Cuiabá, conforme atestam os registros de ocorrências policiais e os processos crimes mencionados neste trabalho. Extravagâncias do tipo eram também notadas em outras partes do Brasil, como na festa de São Benedito da aldeia Tupiniquim de Destacamento, no Espírito Santo, levando o francês Auguste Biard, em 1858, a associar a cantoria ali ouvida aos charivari de seu país ${ }^{1}$. Embora tal comparação não fosse inteiramente acurada - por serem os exemplos franceses ou as rough music inglesas basicamente aqueles folguedos estridentes em que a comunidade humilha os membros que porventura não se comportam conforme as regras estabelecidas - ela dava aos leitores de Biard uma medida da estranheza provocada no visitante em relação a uma cultura festiva que era comum aos costumes dos índios e dos sertanejos e que se aproximava, em certa medida, das práticas populares repressivas e satíricas da Europa pré-industrial2 ${ }^{2}$.

\footnotetext{
${ }^{1}$ BIARD, François Auguste. Dois anos no Brasil. São Paulo: Cia Ed. Nacional, 1945, p. 100.

2 DAVIS, Natalie Zemon. Culturas do povo: sociedade e cultura no início da era moderna. Rio de Janeiro: Paz e Terra, 1990, p. 87-93. Ver também THOMPSON. Edward P. Costumes em comum: estudos sobre a cultura popular tradicional. São Paulo: Companhia das Letras, 1991, p. 353-8.
} 
A festa em Figueira relatada por Schmidt representa uma das cenas do Brasil tradicional e interiorano que este trabalho propôs explicar, por intermédio de sua música e sua dança. Examinando a crônica e a etnologia dos viajantes do século XIX e início do XX, a documentação oficial da época, assim como as pesquisas de folclore e as experiências recentes de campo que possibilitaram a maioria dos registros em música do que se ouviu nas comunidades visitadas, foi possível reunir grande parte da informação já produzida sobre o tema e entrever os seus aspectos formais mais relevantes. Na poesia, por exemplo, pudemos notar a ausência de uniformidade métrica nos versos e o uso raro da rima, sendo o improviso composto apenas de pequenas frases ou fragmentos prontos, adaptados à ocasião. Na música, identificamos, em sua maioria, a divisão de compasso binária simples, as frases curtas com pequenos intervalos melódicos e o acompanhamento monocórdico.

A leitura das fontes também permitiu aventar algumas conclusões a respeito dos seus caminhos históricos. Uma delas diz respeito ao processo de difusão de uma teia de cultura brasilíndia originária dos primeiros povoados paulistas, que teve no Cururu uma de suas expressões mais peculiares. Com a análise de exemplos musicais transcritos e a descrição de aspectos da dança em seus diferentes contextos, foi possível reconhecer a existência de elementos musicais, coreográficos e literários comuns às representações mais antigas de ambas as regiões paulista e mato-grossense (inclusive com o uso de termos como baixão, toada, carreira, etc.), corroborando a tese defendida por autores como Cândido e Maynard Araújo de uma disseminação do Cururu a partir de São Paulo. Admitimos, no entanto, que um maior aprofundamento nas pesquisas seria necessário para que pudéssemos ir além do que se especulou até hoje a respeito das origens do folguedo. A hipótese de ser o Cururu não só uma consequência direta da catequização jesuítica, mas um fenômeno de apropriação por parte dos missionários católicos de danças indígenas preexistentes, conforme o argumento defendido pioneiramente por Couto de Magalhães, ainda carece de mais fundamentos para que seja inteiramente validada. Um caminho, talvez, para a solução deste dilema seja o de unir novos estudos sobre as danças e o cancioneiro tradicional ibérico às investigações sobre a prática musical jesuítica em solo 
americano, buscando seus possíveis reflexos na cultura tradicional local ${ }^{3}$. Por outro lado, tivemos a chance de avançar no entendimento de certas especificidades do Cururu mato-grossense, ao reconhecer que o gênero continuou a individualizarse também através de sua assimilação por algumas etnias indígenas locais e de trocas culturais entre povos das regiões de colonização espanhola. Estes são pontos, aliás, que merecem também estudos futuros.

Se, por um lado, a rusticidade do canto das gentes pobres de Mato Grosso era associada a delitos, muitos deles que resultavam em mortes a facadas, por outro, este mesmo canto constituía-se no meio de expressão erudita dos que conheciam a Letra e a divulgavam exercendo o papel de "evangelizadores da viola", no dizer de Carlos Brandão4. Pudemos ver, neste particular, que o prestígio dos cantadores da fé perante suas comunidades só declinou em razão do processo de romanização da Igreja no Brasil, quando a hierarquia católica reassumiu responsabilidades que antes estavam nas mãos de rezadores, benzedeiras, foliões, cururueiros, etc., permanecendo em alguns rincões apenas os resquícios desta autoridade.

Este Cururu dos excessos das festas, das imposturas dos desafios poéticos ou da devoção aos santos foi muitas vezes censurado e combatido pelos demais segmentos da sociedade local, ao longo do século XIX e início do XX, por fazer parte dos maus costumes atribuídos à gentalha.

Com o advento do Modernismo dos anos 20 e a contribuição dos nascentes estudos na área das ciências sociais, o folclore passou a ser considerado expressão maior da identidade brasileira, inclusive servindo de matéria prima para a cultura ilustrada e orientando em grande medida as políticas de governo para a instrução e a cultura. Assim, as exposições, os festivais, os projetos de pesquisa e resgate da

\footnotetext{
${ }^{3}$ Um indicativo deste possível caminho é o importante trabalho de Rogério Budaz sobre o cancioneiro ibérico utilizado por Anchieta como instrumento de catequese, em cujas melodias o missionário adaptou letras destinadas aos índios, através da técnica conhecida pelo termo contrafacta. Cf. BUDAZ, Rogério. O cancioneiro ibérico em José de Anchieta: um enfoque musicológico. Dissertação de mestrado. São Paulo: ECA-USP, 1996. Outro estudo digno de nota é o de Eduardo Escalante, que procura estabelecer uma ligação entre a melodia vocalizada no baixão dos Cururus e música espanhola, mais precisamente a canción de la trilla da região da Galícia. Cf. ESCALANTE, Eduardo Alberto. A música no Cururu do Médio Tietê paulista. Dissertação de mestrado. São Paulo: ECA-USP, 1986, p. 53-4.

${ }^{4}$ BRANDÃO, Carlos Rodrigues. Sacerdotes de viola: rituais religiosos do catolicismo popular em São Paulo e Minas Gerais. Petrópolis: Vozes, 1981.
} 
memória, as escolas, os museus e os espaços de espetáculos constituíram-se em novos locais de práticas dos artistas populares e artesãos. Estes indivíduos, por sua vez, também viram as suas vidas se transformar, passando a viajar, conceder entrevistas, hospedando-se em hotéis e recebendo eventuais cachês, com a possibilidade de sua antiga diversão se tornar também um meio de sustento. A prática do Cururu, em suma, civilizou-se.

Algumas das recentes mudanças ocorridas em Mato Grosso foram detalhadas no último capítulo deste trabalho: o sucesso do Festival de Cururu e Siriri, a busca de um acento regional para a música popular comercial, assim como a presença da viola-de-cocho nas orquestras locais e a temática folclórica na música de concerto. Nem todos os sujeitos representantes destas novas práticas se encaixam no estereótipo das comunidades ribeirinhas, conforme ilustra o catálogo da temporada 2008 de apresentações da Orquestra de Mato Grosso, onde se vê um músico em traje de gala empunhando uma viola-de-cocho que em nada lembra aparência de um cururueiro (figura 1). Em outros casos, os membros das comunidades tradicionais aparecem plenamente integrados ao espírito dos espetáculos de massa, como os grupos de Siriri que se apresentam nos festivais folclóricos lado a lado com outros bailarinos profissionais, incorporando elementos cênicos exteriores, como os dos figurinos, cenários e enredos tomados de outras expressões.

Ao comentar esta atual tendência de aproximação das práticas culturais tradicionais com os meios massivos, Roberto Benjamin faz uma distinção entre as manifestações de natureza ritual, próprias das comunidades religiosas, e aquelas de caráter mais próximo dos eventos midiáticos. Para este especialista, ambas as modalidades têm sido fortemente influenciadas pela economia do turismo e do entretenimento, sendo, porém, as de cunho religioso mais suscetíveis ao risco da perda de identidade e da descaracterização de suas funções originais ${ }^{5}$. 0 Cururu religioso dos ribeirinhos em Mato Grosso seria um dos exemplos pertencentes à

\footnotetext{
${ }^{5}$ BENJAMIN, R. Folclore no terceiro milênio. Palestra apresentada no IV Seminário de Ações Integradas em Folclore, 31 ago, 2001, p. 4-6. Disponível em: <http://www.cmfolclore.ufma.br/arquivos/318ccea5227f898a37a2ff71ba0260cc.pdf> Acesso em: 24/05/2015.
} 
natureza primeiramente citada, tendo a sua existência ameaçada por estes novos arranjos.

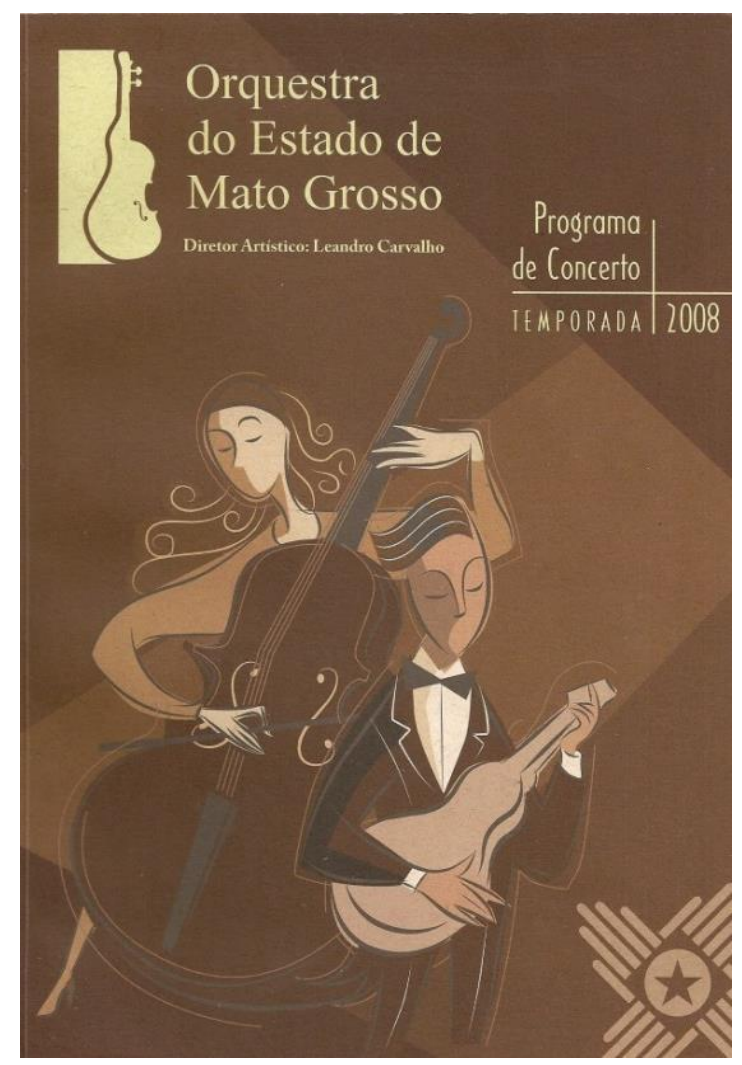

Figura 1: Catálogo de concertos da Orquestra de MT Fonte: SEC, 2008

James Clifford, por outro lado, questiona a noção recorrente de que certos câmbios operados no interior das culturas seriam comparáveis ao processo de falência dos órgãos de um ser vivo fadado a perecer. Seu argumento é o de que as comunidades não estariam baseadas tanto assim numa territorialidade estável, fixadas através de suas raízes, mas aptas a recompor e reelaborar suas identidades frente a profundas mudanças de seus elementos mais críticos: língua, religião, localidade, família e relações de poder 6 . A adaptação da tradição religiosa popular às realidades contemporâneas tem se efetivado nas suas regiões através da conversão de práticas como a do Cururu em bens culturais que são apropriados em diversas instâncias, a dos políticos, dos comerciantes, artistas, artesãos, defensores do acervo arquitetônico, etc.

\footnotetext{
${ }^{6}$ CLIFFORD, James. The predicament of culture: twentieth-century ethnography, literature, and art. Cambridge, MA: Harvard University Press, 1996, p. 338.
} 
Concluo citando Tinhorão, que em seu estudo sobre as festas no Brasil Colonial lamenta o fato de hoje não ser possível ouvir os cantos que animaram as comemorações do país por mais de três séculos, por terem sido poucos os "papéis da música" que se preservaram como registros sonoros desta história. Com eles, certamente saberíamos mais do Cururu em seus primórdios. Mas, como bem disse o autor, "se a música das antigas folganças se perdeu, as festas continuam" 7 .

${ }^{7}$ TINHORÃO, José Ramos. As festas no Brasil colonial. São Paulo: Ed 34, 2000, p. 159. 


\section{CORPUS DOCUMENTAL}

\section{FONTES MANUSCRITAS}

Edital do Diretor do Distrito de Índios de Miranda Frei Mariano de Bagnaia, Miranda, 12 de outubro de 1860. Acervo: APMT, CAIXA 1860 A-3.

Illmo. Exmo. Capitão de Fragata Augusto Leverger Presidente e Comandante das Armas da Província. Doc. Avulso. Cuiabá, 1ํ de agosto de 1853. Acervo: APMT, LATA 1853 B.

Ofício no 130 do Chefe de Polícia Jesuíno de Souza Martins ao Cel. Antonio Pedro de Alencastro. Cuiabá, 24 de agosto de 1860. Acervo: APMT; CAIXA 1860 A-4.

Ofício no 310 do Chefe de Polícia Jesuíno de Souza Martins ao Cel. Antonio Pedro de Alencastro. Cuiabá, 18 de dezembro de 1860, Acervo: APMT, CAIXA 1860 B-2.

Posturas Policiais da Câmara Municipal da Cidade de Cuiabá, de 04 de janeiro de 1831. Acervo: APMT; PM 02, CAIXA 1.

\section{FONTES IMPRESSAS}

\subsection{Documentos oficiais}

ANCHIETA, José de. Cartas, informações, fragmentos históricos e sermões (15541584). Rio de Janeiro: Civilização Brasileira, 1931.

CARDOSO JÚNIOR, Francisco José. Relatório apresentado à Assembleia Legislativa da Província de Mato Grosso, no dia 4 de outubro de 1872. Rio de Janeiro: Typografia do Apóstolo, 1873.

Carta de Nóbrega ao padre Simão Rodrigues, de julho de 1552. In: LEITE, Serafim. Novas cartas jesuíticas. São Paulo: Cia. Ed. Nacional, 1940.

Constituições Primeiras do Arcebispado da Bahia, feitas e ordenadas pelo Ilustríssimo e reverendíssimo Senhor Don Sebastião Monteiro da Vida, arcebispo do dito arcebispado e do Conselho de Sua Magestade: propostas e aceitas em o sínodo diocesano que o dito celebrou em 12 de junho do ano de 1707. [Coimbra, Real Colégio das Artes da Companhia de Jesus, 1720] São Paulo: Typografia Antônio Louzada Antunes, 1953. 
[MOURA, Rolim de]. Carta de 15 de novembro de 1758 a Francisco Xavier de Mendonça Furtado. Rolim de Moura: correspondências. Coleção documentos ibéricos - série: Capitães-generais n. 4 vol. 3. Cuiabá: UFMT, 1983.

NOBREGA, Manuel da. Cartas do Brasil (1549-1560). Rio de Janeiro: Officina Industrial Graphica, 1931.

Relação da viagem que fez o Conde de Azambuja, D. Antonio Rolim, da Cidade de S. Paulo para a Villa de Cuyabá, em 1751. Revista do Instituto Histórico e Geográfico Brasileiro. Rio de Janeiro: L. P. Costa, n. 25 tomo VII, 1815.

Resposta do General Caetano Pinto de Miranda Montenegro ao Parecer sobre o aldeamento dos índios Uaicurus e Guanás, com a descrição dos seus usos, religião, estabilidade e costumes, por Ricardo Franco de Almeida Serra. Revista do Instituto Histórico e Geográfico de Mato Grosso - tomo CXLVI, ano LXX. Cuiabá, 1898.

SIQUEIRA, Joaquim da Costa. Relação Cronológica dos estabelecimentos, fatos e sucessos mais notáveis que aconteceram nestas minas de Cuiabá, registrados nos Livros do Registro das Provisões do Senado da Câmara [1786]. In Crônicas do Cuiabá. Cuiabá: SEC-MT, 2012.

Termo da Junta que fez para a determinação do sítio em que se devia fazer Aldeias dos Padres da Missão. Revista do Arquivo Público de Mato Grosso, Cuiabá, v. 1, n. 2, 1982.

\subsection{Partituras}

Cantigas Populares Brasileiras. Transcrições de Carl von Martius. In: SPIX, Johann Baptist von; MARTIUS, Carl Friedrich Philipp von. Viagem pelo Brasil: 1817-1820. Rio de Janeiro: Imprensa Nacional, 1938.

Cururu e outros cantos das festas religiosas de MT. Transcrições de Edilberto Fonseca. In: VIANNA, Letícia (Org.). Dossiê 8: modo de fazer viola-de-cocho. Brasília: Iphan, 2009.

LACERDA, Osvaldo. Brasiliana n. 3 para piano solo. São Paulo: Irmãos Vitale, 1967.

Sertanejos Cuiabanos (fonogramas 14.608 -9). Transcrições de Astolfo Tavares. In: ROQUETTE-PINTO, Edgard. Rondônia. Rio de Janeiro: Imprensa Nacional, 1919.

\subsection{Viajantes}

BIARD, François Auguste. Dois anos no Brasil. São Paulo: Cia Ed. Nacional, 1945.

CARDIM, Fernão. Tratados da terra e gente do Brasil. São Paulo: Cia. Ed. Nacional, 1978 [1584]. 
CASTELNAU, Francis de. Expedição às regiões centrais da América do Sul. São Paulo: Cia. Ed. Nacional, 1949.

FERREIRA, Alexandre Rodrigues. A expedição filosófica pelas capitanias do Pará, Rio Negro, Mato Grosso e Cuiabá. Petrópolis, RJ: Kapa Editorial, 2005 [1783-1792].

FLORENCE, Hercules. Viagem fluvial do Tietê ao Amazonas de 1825 a 1829. Brasília: Senado Federal, 2007.

KOSLOWSKY, Julio. Tres semanas entre los indios Guatós: excursión efectuada en 1894. Revista del Museo de La Plata. Tomo VI, 1895.

MOUTINHO, Joaquim Ferreira. Notícia sobre a província de Mato Grosso seguida d'um roteiro da viagem da sua capital a S. Paulo. São Paulo: Typografia de Henrique Schroeder, 1869.

SAINT-HILAIRE, Auguste de. Viagem às nascentes do rio S. Francisco e pela província de Goyaz. São Paulo: Cia. Ed. Nacional, 1937.

SCHMIDT, Max. Estudos de etnologia brasileira: peripécias de uma viagem entre 1900 e 1901. São Paulo: Cia. Ed. Nacional, 1942.

. Resultados a minha expedição bienal a Mato Grosso, de setembro de 1926 a agosto de 1938. Boletim do Museu Nacional. Rio de Janeiro: Imprensa Nacional, XIV - XVII, 1942. p. 242.

Resultados de mi tercera expedición a los Guatos efectuada en el año de 1928. Revista de la Sociedad Científica del Paraguay, Asunción, 5(6), 1942.

SPIX, Johann Baptist von; MARTIUS, Carl Friedrich Philipp von. Viagem pelo Brasil: 1817-1820. Rio de Janeiro: Imprensa Nacional, 1938.

STEINEN, Karl von den. Entre os aborígenes do Brasil central. São Paulo: Dep. de Cultura, 1940.

. O Brasil central: expedição em 1884 para a exploração do rio Xingu. São

Paulo: Cia. Ed. Nacional, 1942.

Duch Central-Brasilien: expedition zur erforschung des Schingú in jahre 1884. Leipzig: F. A. Borockhaus, 1886.

ROQUETTE-PINTO, Edgard. Rondônia. Rio de Janeiro: Imprensa Nacional, 1919.

VICENZI, Jacomo. Paraíso verde: impressões de uma viagem a Mato Grosso em 1918. Ed. do autor s.d.

WIED-NEUWIED, Maximilian. Viagem ao Brasil nos anos de 1815 a 1817. São Paulo: Cia Ed. Nacional, 1940. 


\subsection{Folcloristas}

AMERICANO do BRASIL, Antônio. Cancioneiro de trovas do Brasil Central. Goiânia: Oriente, $2^{\mathrm{a}}$ ed. 1973.

ARAÚJO, Alceu Maynard. Cururu rural. In: Semana Nacional de Folclore. Rio de Janeiro: IBECC/CNF, 1949.

Cultura popular brasileira. São Paulo: Melhoramentos, 1973.

BRASILEIRO, Francisco. Monografia folclórica do Rio das Garças. Separata da Revista do Arquivo. São Paulo: Dep. de Cultura, 1951.

CARNEIRO, Edson. Folguedos tradicionais. Rio de Janeiro: Conquista, 1974.

CASCUDO, Luiz da Câmara. Dicionário do folclore brasileiro. Rio de Janeiro: Global, 2000.

CHIARINI, João. Cururu. In: Revista do Arquivo Municipal São Paulo. SP: Dep. de Cultura, 1947.

COUTO DE MAGALHÃES, General. Anchieta e as raças e as línguas indígenas. $7^{\mathrm{a}}$ Conferência para o tricentenário de Anchieta. São Paulo: Typografia C. Gerke e Cia, 1897.

o Selvagem. Belo Horizonte: Itatiaia, 1975.

DAMANTE, Hélio. Folclore brasileiro. Rio de Janeiro: INF/FUNARTE, 1980.

LIMA, Rossini Tavares de. Folclore de São Paulo. SP: Ricordi, 1978.

. Folclore de São Paulo: melodia e ritmo. São Paulo: Ricordi, 1961.

Estado, 1962.

O folclore na obra de escritores paulistas. São Paulo: Imprensa Oficial do

LOUREIRO, Roberto. Cultura mato-grossense: festas de santos e outras tradições.

Cuiabá: Entrelinhas, 2006.

PIRES, Cornélio. Conversas ao pé-do-fogo. Itu, SP: Ottoni, 2002.

RIBEIRO, João. O folk-lore: estudos de literatura popular. Rio de Janeiro: Jacinto Ribeiro dos Santos, 1919.

RIBEIRO, Joaquim. Folklore dos bandeirantes. Rio de Janeiro: José Olympio, 1946. 
RODRIGUES, João Barbosa. Poranduba amazonense. Rio de Janeiro: Leuzinger \& filhos, 1890.

\section{FONTES SONORAS E AUDIOVISUAIS}

Cururu e outros cantos das festas religiosas de MT. Documentário Sonoro do Folclore Brasileiro v. 45. Áudio LP (32:50 min). Rio de Janeiro: MEC/INF, 1988.

Entrevista com Seu Tuti, gravada em vídeo VWM. Chapada dos Guimarães, 18 de junho de 2012.

Entrevista com Prof. Jeferson Ribeiro gravada, em vídeo MP4. Santo Antônio de Leverger, 20 de agosto de 2014.

Entrevista com Sr. Gonçalo Siqueira gravada, em vídeo VWM. Poconé, 21 de junho de 2012.

Entrevista com Sr. Lourenço Ferreira Mendes, gravada em vídeo VWM. Cáceres, 20 de agosto de 2012.

Informações obtidas por e-mail com o Professor Jorge Eremites de Oliveira <eremites@ufgd.edu.br> em: 26/04/2012.

Mandi e Sorocabinha. Cururu. Rio de Janeiro: Odeon. Fonograma cod. 11368-A, 1936.

PEREIRA, Edmundo; PACHECO, Gustavo (Produtores). Rondônia 1912: gravações históricas de Roquette-Pinto. Áudio CD. Rio de Janeiro: Museu Nacional/UFRJ, 2008.

Pescuma, Henrique e Claudinho. Rasqueia Brasil. São Paulo: MCK. DVD cod.

7899004726787, 2010.

PIZZINI, Joel (Dir.). 500 Almas. São Paulo: Grifa Filmes. DVD (109 min.), son. Color, 2005.

Seu Tuti. Ensaio para apresentação na Mostra de música de Chapada dos Guimarães, em 28 e 29/09/2012. Disponível em:

<https://www.youtube.com/watch?v=YNZZCjyry-E > Acesso em: 25/04/2015.

\section{FONTES ACESSADAS NA INTERNET}

\subsection{Documentos oficiais e órgãos públicos}

Diretório que se deve observar nas Povoações dos Índios do Pará, e Maranhão. Alvará de 7 de junho de 1755. Disponível em:< 
http://www.iuslusitaniae.fcsh.unl.pt/verlivro.php?id parte=105\&id obra=73\&pag ina $=532>$ Acesso em: 03/09/2013.

Decreto no 426 de 24 julho de 1845, que contém o regulamento acerca das Missões de catequese e civilização dos índios. Disponível em:

$<$ http://legis.senado.gov.br/legislacao/ListaTextoIntegral.action?id=66320\&norm $\underline{\mathrm{a}=82240}>$ Acesso em: 03/09/2013.

ORQUESTRA DO ESTADO DE MATO GROSSO. Temporada 2013. Disponível em: <http://www.orquestra.mt.gov.br/noticias.php?not id=30 > Acesso em: 21/04/2015.

PREFEITURA MUNICIPAL DE CUIABÁ. Catálogo do 8o Festival Siriri Cururu. Cuiabá: Central de Texto, 2009.

$<$ https://10festivalcururusiriri.wordpress.com/2011/10/26/regulamento-do-10festival-cururu-siriri/> Acesso em: 12/04/2015.

SECRETARIA DE ESTADO DA CULTURA. Orquestra de câmara do Estado estreia "Sinfonia Pantaneira". Cuiabá, 2004. Disponível em:

<http://www3.cultura.mt.gov.br/TNX/imprime.php?cid=751\&sid=54 > Acesso em 24/03/2014.

UNIVERSIDADE FEDERAL DE MATO GROSSO. Pró-reitoria de Cultura, Extensão e Vivência. Disponível em:

<http://www.ufmt.br/ufmt/unidade/index.php/secao/siteAlt/1168/137/PROCE V> Acesso em: 24/04/2015.

\subsection{Jornalismo}

24 horas News. Começa o debate da TV Centro América com os cinco candidatos à prefeitura de Cuiabá. Disponível em:

http://www.24horasnews.com.br/index.php?mat=269106. Acesso em: 28/09/2014.

AGÊNCIA DE NOTÍCIAS DOS MUNICÍPIOS. Publicado em 29/06/2007. Disponível em: <http://www.lajeado.to.gov.br/003/00301009.asp?ttCD CHAVE=58649> Acesso em: 12/04/2015.

AURÉLIO, Max. Grupo Pixé de Nova Mutum é destaque em MT. Weblog publicado em 21/09/2009. Disponível em:< http://www.jonalterritorios.com/2009/09/grupopixe-de-nova-mutum-e-destaque-em.html > Acesso em: 12/04/2015.

BOSQUO, João. Para quem não sabe o que é Cururu e Siriri. Webblog publicado em 10/10/2008. Disponível em: < https://jbas.wordpress.com/2008/10/10/paraquem-ainda-no-sabe-cururu-e-siriri/> Acesso em: 12/04/2015.

FERREIRA, Eduardo. A peleja da viola-de-cocho com o anjo mineiro. Weblog publicado em 20/10/2006. Disponível em:< 
http://www.overmundo.com.br/overblog/peleja-da-viola-de-cocho-com-o-anjomineiro > Acesso em: 19/03/2015.

FERREIRA, João Carlos Vicente. A propósito da orquestra de Mato Grosso. Olhar Direto - Cuiabá, MT. publicado em 27/04/2010. Acesso em

$<$ http://www.olhardireto.com.br/artigos/exibir.asp?id=1620 > Acesso em: 21/05/2013.

GAZETA DIGITAL. Coluna Aparte. Disponível em:

$<$ http://www.gazetadigital.com.br/materias.php?codigo $=267640 \&$ codcaderno $=10$ $\underline{\mathrm{GED}}=6838 \& \mathrm{GEDDATA}=2010-08-$ 19\&UGID=bfaa2086cb30ecfb46c65cef149eea10 > Acesso em: 28/09/2014.

G1 MATO GROSSO. Cuiabá será tema de enredo da Mangueira no carnaval de 2013 em RJ. Publicado em 07/05/2012. Disponível em:<http://g1.globo.com/matogrosso/noticia/2012/05/cuiaba-sera-tema-de-escola-de-samba-no-rio-de-janeiroem-2013.html > Acesso em: 23/04/2015.

MACHADO, Marcela. A noite é do rock! Portal RDM online. Disponível em $<$ http://www.rdmonline.com.br/TNX/imprime.php?cid=4147\&sid=53 > Acesso em: 22/04/2015.

MEDEIROS, Stéfanie. Lançamento de documentário que conta a história da guitarrade-cocho será neste sábado. Portal Olhar Direto. Publicado em 14/04/2015.

Disponível em:

$<$ http://www.olhardireto.com.br/conceito/noticias/exibir.asp?noticia=Lancament o de documentario que conta a historia da guitarra-decocho sera neste sabado\&id=7365 > Acesso em: 02/05/2015.

PERIPATO, Sandra Cristina. Turma Caipira Victor. São Paulo: Portal Recanto Caipira, 2008. Disponível em:

$<$ http://www.recantocaipira.com.br/turma caipira victor.html $>$ Acesso em: $02 / 05 / 2015$.

REPÓRTER NEWS. Caravana Roda Cururu Siriri na estrada. Publicado em 22/05/2007. Disponível em:

$<$ http://www.reporternews.com.br/noticia/225920/Caravana Roda Cururu Siriri na estrada >Acesso em: 12/04/2015. 


\section{BIBLIOGRAFIA}

A Bíblia Sagrada. São Paulo: Sociedade Bíblica do Brasil, 1978.

ANCHIETA, José de. Auto representado na festa de São Lourenço. Rio de Janeiro: Serviço Nacional de Teatro - MEC, 1973.

ANDRADE, Julieta de. Cocho mato-grossense: um alaúde brasileiro. São Paulo: Editorial Livramento, 1981.

ANDRADE, Mário de. Danças dramáticas do Brasil. Belo Horizonte: Itatiaia, 1982. . Pequena história da música. São Paulo: Vila Rica, 1972.

Dicionário Musical Brasileiro. Belo Horizonte: Itatiaia, 1999. Ensaio sobre a música brasileira. Belo Horizonte: Itatiaia, 1972.

ANJOS FILHO, Abel Santos. Viola-de-cocho: novas perspectivas. Cuiabá: EdUFMT, 1993.

SEC, 2002.

Uma melodia histórica: eco, cocho, cocho-viola, viola-de-cocho. Cuiabá:

ARIANO, Heloisa Afonso. Vozes da Cuiabania: identidade e globalização no rasqueado cuiabano. Dissertação de mestrado em Antropologia. Curitiba: UFPR, 2002.

AZEVEDO, Luiz Heitor Corrêa. Relação dos discos gravados no Estado de Goiás (junho de 1942). Rio de Janeiro: MCML, 1950.

BALDUS, Herbert. Ensaios de etnologia brasileira. São Paulo: Cia. Ed. Nacional, 1937.

BARBOSA, Pe. Alemos. Pequeno vocabulário tupi-português. Rio de Janeiro: Livraria São José, 1967.

BEZERRA, Sílvia Ramos. Contradições Culturais do Cortejo Triunfante da Modernidade em Mato Grosso. Fênix - Revista de História e Estudos Culturais. Jul a Set 2008.

BORGES. Ana Carolina da Silva. Nas margens da história: meio ambiente e ruralidade em comunidades "ribeirinhas" do Pantanal Norte: 1870-1930. Cuiabá: Ed UFMT/ Carlini \& Caniato, 2010. 
BOURCIER, Paul. História da dança no Ocidente. São Paulo: Martins Fontes, 2006.

BRANDÃO, Carlos Rodrigues. Os deuses do povo: um estudo sobre a religião popular. Uberlândia, MG: EdUFU, 2007. . Prece, folia, festa e romaria. Aparecida, SP: Ideias e Letras, 2010. Sacerdotes da viola: rituais religiosos do catolicismo popular em São Paulo e Minas Gerais. Petrópolis: 1981.

BUDAZ, Rogério. $O$ cancioneiro ibérico em José de Anchiea: um enfoque musicológico. Dissetação de mestrado. São Paulo: Usp, 1996.

BURKE, Peter. Cultura popular na Idade Moderna: Europa 1500-1800. São Paulo: Cia das Letras, 2010.

Cadernos de Cultura - Siriri. Cuiabá: Central de Texto, 2006.

CANCLINI, Néstor García. Culturas híbridas: estratégias para entrar e sair da modernidade. São Paulo: Edusp, 2013.

CÂNDIDO, Antônio. Possíveis raízes indígenas de uma dança popular. In: Shaden, Egon. Leituras de etnologia brasileira. São Paulo: Cia Ed. Nacional, 1976.

Os parceiros do Rio Bonito: estudo sobre o caipira paulista e a transformação dos seus meios de vida. São Paulo: José Olympio, 1964.

CAREAGA, Aroldo. Salesianos e Bororo nos sertões mato-grossenses: das práticas missionárias às resistências culturais (1894-1910). Revista Nures n. 16, Set/Dez 2010 - Núcleo de Estudos Religião e Sociedade - Pontifícia Universidade Católica SP p. 2 Disponível em: < http://www.pucsp.br/revistanures > acesso em: $02 / 10 / 2014$.

CARVALHO, Maria Michol Pinho de. Divino Espírito (re)ligando Portugal/Brasil no imaginário religioso popular. VI Congresso português de sociologia. Universidade Nova de Lisboa, FCSH, Jun, 2008. Disponível em:

<http://www.aps.pt/vicongresso/pdfs/188.pdf> acesso em: 24/11/2014.

CASTAGNA, Paulo. A música como instrumento de catequese no Brasil dos séculos XVI e XVII. D.O. Leitura. São Paulo, ano 12, n.143, 1994.

CERTEAU, Michel de. A cultura no plural. Campinas, SP: Papirus, 2005. A Invenção do Cotidiano: arte de fazer. Petrópolis: Vozes, 1994.

CHARTIER, Roger. A história cultural: entre práticas e representações. Lisboa: Difel, 2002. 
. À beira da falésia: a história entre certezas e inquietudes. Porto Alegre: EdUFRGS, 2002.

. Do palco à página: publicar teatro e ler romances na época moderna séculos XVII - XVIII. Rio de Janeiro: Casa da Palavra, 2002.

CHAVES, Luís. Danças religiosas. In: Revista Guimarães. Vol LI, 1942.

CLIFFORD, James. The predicament of culture: twentieth-century ethnography, literature, and art. Cambridge, MA: Harvard University Press, 1996.

CORRÊA FILHO, Virgílio. História de Mato Grosso. Rio de Janeiro: Instituto Nacional do Livro, 1969.

CUNHA, Antônio Geraldo. Dicionário histórico das palavras portuguesas de origem tupi. São Paulo: Melhoramentos, 1989.

DAVIS, Natalie Zemon. $O$ retorno de Martin Guerre. Rio de Janeiro: Paz e Terra, 1987.

Culturas do povo: sociedade e cultura no início da era moderna. Rio de Janeiro: Paz e Terra, 1990.

Enciclopédia da Música Brasileira: erudita, folclórica e popular. São Paulo: Art Editora, 2 v. 1977.

ESCALANTE, Eduardo A. A festa de Santa Cruz da aldeia de Carapicuíba no estado de São Paulo. Rio de Janeiro: MEC-SEC/FUNARTE, 1981.

. A música no Cururu do Médio Tietê Paulista. Dissertação de Mestrado. São Paulo: ECA/USP, 1986.

FERNANDES. João Azevedo. Selvagens bebedeiras: álcool, embriaguez e contatos culturais no Brasil colonial. Tese de doutorado em história. Niterói, RJ: UFF, 2004.

FRANCO, Maria Sylvia de Carvalho. Homens livres na ordem escravocrata. São Paulo: Ed Unesp, 1997.

FREITAS, Maria Auxiliadora de. Cuiabá, imagens da cidade: dos primeiros registros à década de 1960. Cuiabá: Entrelinhas, 2011.

GADELHA, Regina Maria A. F. As missões jesuíticas do Itatim: um estudo das estruturas socioeconômicas coloniais do Paraguai, séculos XVI e XVII. Rio de Janeiro: Paz e Terra, 1980.

GALETTI, Lylia da Silva Guedes. Sertão, fronteira, Brasil: imagens de Mato Grosso no mapa da civilização. Cuiabá: Entrelinhas, 2012. 
GAVILÁN, Diego. iGuarani: dicionário traductor guarani. Disponível em: < http://www.iguarani.com > acesso: 15/02/2015.

GINZBURG. Carlo. Mitos, emblemas, sinais: morfologia e história. São Paulo: Companhia das Letras, 1989.

GRANDO, Beleni Saléte (org.). Cultura e dança em Mato Grosso. Cuiabá: Central de texto, 2005.

GUAPO, Milton Pereira de Pinho. Remedeia co que tem. Cuiabá: Carlini \& Caniato, 2010.

GUIMARÃES, Suzana. Arte na rua: o imperativo da natureza. Cuiabá: EdUFMT, 2007.

GUSHIKEN, Yuri. Mapa das festas de santos da grande Cuiabá e interlândias. Anuário da Cátedra Unesco/Metodista de Comunicação para o Desenvolvimento Regional. Universidade Metodista de São Paulo Ano 16, no. 16, p. 47-66, jan/dez 2012.

HALL, Stuart. A identidade cultural na pós-modernidade. Rio de Janeiro: DP\&A, 2006.

HOBSBAWM, Eric. \& RANGER, Terence (org.) A invenção das tradições. São Paulo: Paz e Terra, 1977.

HOLANDA, Sérgio Buarque de (org.). História geral da civilização brasileira. São Paulo: Difel, 1976.

HOLANDA, Sérgio Buarque de. Caminhos e fronteiras. Rio de Janeiro: José Olympio, 1957. Monções. São Paulo: Alfa-Ômega, 1976.

HOLLER, Marcos. Os jesuítas e a música no Brasil colonial. Campinas, SP: Unicamp, 2010.

. Uma história de cantares de Sion na terra dos brasis: a música na atuação dos jesuítas na América Portuguesa (1549-1759). Tese de doutorado em musicologia. Campinas, SP: UNICAMP, 2006.

HOORNAERT, Eduardo (Org.) História da Igreja no Brasil: ensaio de interpretação a partir do povo. Petrópolis, RJ: Vozes, 1992.

IKEDA, Alberto. Cururu: resistência e adaptação de uma modalidade musical da cultura tradicional paulista. In Folias de reis, sambas do povo. São José dos Campos, SP: CECP/FCCR, 2011. 
LOPES, Aaron Roberto de Mello. O Festival Cururu Siriri e seus impactos: espetacularização e inovação de duas tradições mato-grossenses. Anais do II SIMPOM, Rio de Janeiro: UNIRIO, 2012.

LUCIDIO, João Antonio Botelho. Ofício e Arte: fotógrafos e fotografia em Mato Grosso (1860-1960). Cuiabá: Carlini e Caniato/EdUFMT, 2008.

MARTINS JÚNIOR, Moisés Mendes. Revendo e reciclando a cultura cuiabana. Cuiabá: Janina, 2006.

MENDES, Francisco Alexandre Ferreira. Lendas e tradições cuiabanas. Cuiabá: FCMT, 1977.

MENDES, Marcos Amaral. Devoção e território: a Irmandade de São Benedito em Cuiabá (1722-1897). Território e Fronteiras - ICHS/UFMT V. 4 N.1 - Jun/Jul 2011.

MERHY, Silvio Augusto. As transcrições das canções populares em Viagem pelo Brasil de Spix e Martius. Revista brasileira de música. RJ: UFRJ, 2010.

MENDONÇA, Rubens de. Roteiro histórico e sentimental da Vila Real do Bom Jesus de Cuiabá. Cuiabá: Igrejinha, 1975.

MOREIRA, Yara. De Folias, de Reis e de Folias de Reis. Revista goiana de artes. UFG vol. 3 n. 2 jul/dez 1982.

NETO, Miranda. A utopia possível: missões jesuíticas em Guairá, Itatim e Tape, 16091767, e seu suporte econômico-ecológico. Brasília: FUNAG, 2012.

NEUBURGUER, Martina. Engenho Velho e Miguel Velho: comunidades ribeirinhas em transformação. Cuiabá: Cadernos do NERU/UFMT, n³, Set. 1994.

OLIVEIRA, João Pacheco de. Uma etnologia dos “índios misturados"? Situação colonial, territorialização e fluxos culturais. Revista MANA n. 4 v.1, 1998.

OLIVEIRA, Jorge Eremites de. Os primeiros passos em direção a uma arqueologia pantaneira: de Max Schmidt e Branka Susnik a outras interpretações sobre os povos indígenas nas terras baixas do Pantanal. Revista de Arqueologia. São Paulo: SAB, v. 20, 2007.

ORTIZ, Renato. Cultura brasileira e identidade nacional. São Paulo: Brasiliense, 2012.

PAZ, Vanessa Carneiro da. Encontros em defesa da cultura nacional: o Conselho Federal de Cultura e a regionalização da cultura na ditadura civil-militar (19661976). Dissertação de mestrado. Niterói-RJ: UFF/ICHF, 2011.

PEQUENO, Mercedes Reis. Três Séculos de Iconografia da música no Brasil. Catálogo de exposição. Rio de Janeiro: Biblioteca Nacional, 1974. 
PEREIRA, Niomar de Souza. São Gonçalo nós louvamos com canto, dança e viola. Revista goiana de artes. Goiânia: IA/UFG, v. 7 n. 1, jan/dez 1986.

PEREIRA JR, Cleber Alves. O código de posturas e o futuro cururu oitocentista. Anais do XXV Simpósio Nacional de História. Fortaleza,CE 2009. 8p. Disponível em <http://anpuh.org/anais/wp-content/uploads/mp/pdf/ANPUH.S25.1325.pdf> acesso: $28 / 08 / 2014$.

PRIORE, Mary Del. Festas e utopias do Brasil colonial. São Paulo: Brasiliense, 1994.

RANGEL, Jorge Antonio. Edgard Roquette-Pinto. Coleção Mec Educadores. Recife: FJN/Massangana, 2010.

REIS, Rai; BARROS, Lidiane. Siriri e Cururu: explosão de ritmos e cores. Cuiabá: Carlini e Caniato, 2013.

RIBAS, Tomaz. Danças populares portuguesas. Amadora, Portugal: Bertrand, 1983.

RIBEIRO, Darcy. O povo brasileiro: a formação e o sentido do Brasil. São Paulo: Companhia das Letras, 2006.

ROCHA, Anderson. A viola-de-cocho como símbolo das tradições em um novo Mato Grosso. Anais do V Simpósio Internacional de História. Goiânia: Anpuh/UFG, 2011.

ROCHA, Eunice Ajala. Uma expressão do folclore mato-grossense: cururu em Corumbá. Dissertação de mestrado. Porto Alegre: PUCRS/BCE, 1981.

SANTOS, Danilo José dos. A procissão de Corpus Christi na Vila de Santo Antônio do Recife no século XVIII como espaço de devoção, status e manutenção do prestígio régio na América portuguesa. Anais do II Encontro Internacional de História Colonial. UFRN, Caicó (RN), v.9 n. 24, set/out 2008. Disponível em:

<http://www.cerescaico.ufrn.br/mneme/anais/st_trab_pdf/pdf_4/danilo_st4.pdf> acesso: 10/01/2015.

SANTOS, Giordana Laura da Silva. O Siriri na contemporaneidade em Mato Grosso: suas relações e trocas. Dissertação de Mestrado. Cuiabá: UFMT, 2010.

SANTOS, Paulo Sérgio Nolasco dos. "Representações artísticas e limites espaciais: o regionalismo revisitado" In: RUSSEF, Ivan \& SANTOS, Paulo Sérgio Nolasco dos (org.) Ensaios farpados: arte e cultura no pantanal e no cerrado. Campo Grande: Letra Livre, 2004.

SANTOS FILHO, Francisco Lopes dos. Planalto Central: marco da música contemporânea em Mato Grosso. Dissertação de mestrado. Cuiabá: UFMT/IL, 2011.

SCHMACHTENBERG, Ricardo. Código de posturas e regulamentos: vigiar, controlar e punir. Anais do IX Encontro Estadual de História. Porto Alegre, RS jul 2008 
UFRS/ANPUH-RS 13 p. Disponível em <http://eeh2008.anpuh-

rs.org.br/resources/content/anais/1209158027 ARQUIVO CODIGOSDEPOSTURA S.pdf> Acesso: 28/08/2014.

SENA, Divino Marcos de. Camaradas: livres e pobres em Mato Grosso (1808-1850). Dissertação de mestrado em história. Dourados, MS: UFGD, 2010.

SILVA, Giovani José da. Enciclopédia dos povos indígenas.

<http://pib.socioambiental.org/pt/povo/guato/print> Acesso em: 07/08/2013.

SILVA, Verone Cristina. Missão, aldeamento e cidade: os Guaná entre Albuquerque e Cuiabá (1819-1901). Dissertação de mestrado em história. Cuiabá: UFMT, 2001.

SIQUEIRA. Elizabeth Madureira. História de Mato grosso: da ancestralidade aos dias atuais. Cuiabá: Entrelinhas, 2002.

TAUNAY, Visconde de. A retirada da laguna: episódio da guerra do Paraguai. São Paulo: Melhoramentos, 1952.

Inocência. São Paulo: Moderna, 2000.

TINHORÃO, José Ramos. As festas no Brasil colonial. São Paulo: Editora 34, 2000.

THOMPSON. Edward P. Costumes em comum: estudos sobre a cultura popular tradicional. São Paulo: Companhia das Letras, 1991.

VIANNA, Letícia (Org.). Dossiê 8: modo de fazer viola-de-cocho. Brasília: Iphan, 2009.

. "O caso de registro da viola-de-cocho como patrimônio imaterial", in Sociedade e Cultura. Goiânia: UFG, V. 8 N. 2, 2005.

VILELA, Ivan. Cantando a própria história. Tese de doutorado. São Paulo: USP, 2011.

VOLPATO, Luiza Rios Ricci. Cativos do sertão: vida cotidiana e escravidão em 1850/1888. Cuiabá: Marco Zero, 1993. 


\section{ÁUDIO CD EM ANEXO}

Faixa 1 - Cururu cantado por Aluísio Silva. N. S. do Livramento, MT.

Faixa 2 - Cururu cantado por Lourenço Ferreira Mendes. Cáceres, MT.

Faixa 3 - Cururu cantado por Miguel Arcanjo de Souza e companheiros. Poconé, MT.

Faixa 4 - Canto Sertanejo Cuiabano registrado por E. Roquette-Pinto (executado pelo autor para este trabalho).

Faixa 5 - Canto Sertanejo Cuiabano registrado por E. Roquette-Pinto (executado pelo autor para este trabalho).

Faixa 6 - Cururu cantado por Sr. Gonçalo. Santo Antônio de Leverger, MT.

Faixa 7 - Cururu cantado por Euclides Maia da Silva e companheiros. Cuiabá, MT.

Faixa 8 - Siriri cantado pelo grupo de Da. Marcolina. Cuiabá, MT.

Faixa 9 - Siriri cantado por Seu Tuti. Chapada dos Guimarães, MT.

Faixa 10 - Festa da Santidade, obra de Danilo Guanais, executada pela Orquestra de Mato Grosso e coro. Cuiabá, MT.

Faixa 11 - Sinfonia Pantaneira, de Abel dos Anjos, executada pela Orquestra Sinfônica da UFMT. Cuiabá, MT.

Faixa 12 - Cururu cantado por Mandi e Sorocabinha, gravado pela Odeon. São Paulo, SP.

Faixa 13 - É Bem Mato Grosso, cantada por Pescuma, Henrique e Claudinho pela MCK. Cuiabá, MT. 